The Journal of Public Space is the first, international, interdisciplinary, academic, open access journal entirely dedicated to public space. It speaks different languages and is open to embrace diversity, inconvenient dialogues and untold stories, from multidisciplinary fields and all countries, especially from those that usually do not have voice, overcoming the Western-oriented approach that is leading the current discourse.

As a proper public space, The Journal of Public Space is free, accessible and inclusive, providing a platorm for emerging and consolidated researchers; it is intended to foster research, showcese best practices and inform discussion about the more and more important issues related to public spaces in our changing and related to public

The Journal of Public Space

2018 | Vol. 3 n. 2

Editor Luisa Bravo

Guest Editor Maggie McCormick

ISSN 2206-9658

(c) $\underset{\text { (i) }(9)}{(9)}$ http://www.journalpublicspace.org

O) City Space UN(EHABITAT

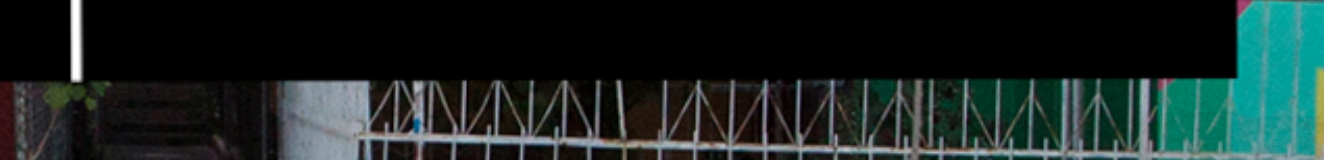

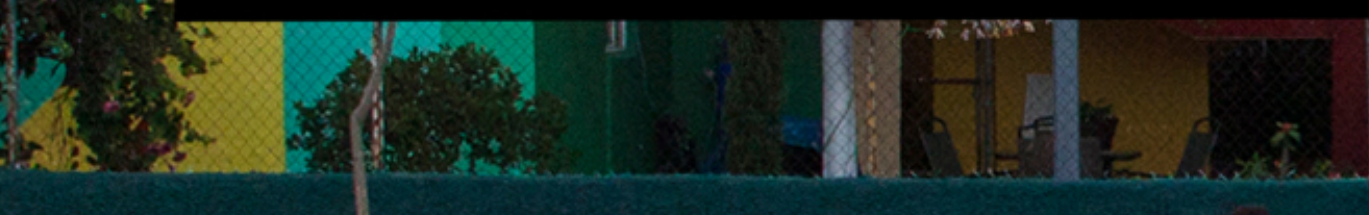

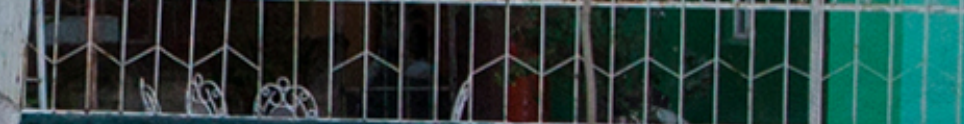




\section{EDITORIAL TEAM}

\section{Editor in Chief}

Luisa Bravo, City Space Architecture, Italy

\section{Scientific Board}

Davisi Boontharm, Meiji University, Japan

Simone Brott, Queensland University of Technology, Australia

Julie-Anne Carroll, Queensland University of Technology, Australia

Margaret Crawford, University of California Berkeley, United States of America

Philip Crowther, Queensland University of Technology, Australia

Simone Garagnani, University of Bologna, Italy

Pietro Garau, University of Rome "La Sapienza”, Italy

Carl Grodach, Monash University, Australia

Chye Kiang Heng, National University of Singapore, Singapore

Miquel Marti, Universitat Politècnica de Catalunya, Spain

Maggie McCormick, RMIT University, Australia

Darko Radovic, Keio University, Japan

Estanislau Roca, Universitat Politècnica de Catalunya, Spain

Joaquin Sabate, Universitat Politècnica de Catalunya, Spain

Robert Saliba, American University of Beirut, Lebanon

Claudio Sgarbi, Carleton University, Canada

Hendrik Tieben, Chinese University of Hong Kong, Hong Kong

\section{Strategic Advisory Board}

Cecilia Andersson, UN-Habitat Global Public Space Programme, Kenya

Tigran Haas, KTH Royal Institute of Technology, Sweden

Micheal Mehaffy, KTH Royal Institute of Technology, Sweden

Laura Petrella, UN-Habitat Global Public Space Programme, Kenya

\section{Advisory Board for Research into Action}

Ethan Kent, Project for Public Spaces, United States of America

Gregor Mews, Urban Synergies Group, Australia

Luis Alfonso Saltos Espinoza, LASE+CityUrb, Ecuador

\section{Journal Manager}

Luisa Bravo, City Space Architecture, Italy 


\section{Correspondents and Peer Reviewers}

Roberto Andrés, Universidade Federal de Minas Gerais, Brazil

Michael Barke, University of Northumbria at Newcastle, United Kingdom

Gem Barton, Brighton University, United Kingdom

Simon Bell, Estonian University of Life Sciences, Estonia

Christopher Brisbin, University of South Australia, Australia

Liz Brogden, Queensland University of Technology, Australia

Martin Bryant, University of Technology Sydney, Australia

Glenda Caldwell, Queensland University of Technology, Australia

Philippa Carnemolla, University of Technology Sydney, Australia

Dave Colangelo, Portland State University, United States of America

Debra Cushing, Queensland University of Technology, Australia

Pak Damrongsak, Thammasat University, Thailand

Camilo Vladimir de Lima Amaral, Universidade Federal de Goias, Brazil

Raul Dias De Carvalho, Queensland University of Technology, Australia

Thomas Fowler, California Polytechnic State University, United States of America

Emilio Garcia, University of Auckland, New Zealand

Pedro Ressano Garcia, Universidade Lusófona, Portugal

Morten Gjerde, Victoria University of Wellington, New Zealand

Maria Goula, Cornell University, United States of America

Adrian Gras-Velazquez, Swarthmore College, United States

Kai Gu, University of Auckland, New Zealand

Daniel O'Hare, Bond University, Australia

Phil Heywood, Queensland University of Technology, Australia

Konstantinos loannidis, Aristotle University of Thessaloniki, Greece

Marjut Kirjakka, Aalto University, Finland

Anoma Kumarasuriyar, Queensland University of Technology, Australia

Matthew D. Lamb, Pennsylvania State University, United States of America

Yoav Lerman, Tel Aviv University, Israel

Marieta Maciel, Universitade Federal de Minas Gerais, Brazil

Michael Marriott, Queensland University of Technology, Australia

Nicola Marzot, TU Delft, Netherlands 
Galyna MacLellan, Queensland University of Technology, Australia Marisha McAuliffe, Queensland University of Technology, Australia Ari Mattes, University of Notre Dame, Australia Linda Matthews, University of Technology Sydney, Australia John Mongard, The Designbank, Australia Milica Muminović, University of Canberra, Australia

Nga Nguyen, Vietnam National University Ho Chi Minh City, Vietnam

Vitor Oliveira, University of Porto, Portugal

Kaan Ozgun, University of Queensland, Australia Leonardo Parra, Universidad de Los Andes, Colombia Mark Pennings, Queensland University of Technology, Australia Gavin Perin, University of Technology Sydney, Australia Helena Piha, Queensland University of Technology, Australia Dorina Pojani, University of Queensland, Australia Lakshmi Priya Rajendran, Anglia Ruskin University, United Kingdom Renato Rego, Universidade Estadual de Maringá - UEM, Brazil Yodan Rofe, Ben-Gurion University of the Negev, Israel Paul Sanders, Queensland University of Technology, Australia Leigh Shutter, Griffith University, Australia Massimo Santanicchia, Iceland Academy of the Arts, Iceland Thomas Sigler, University of Queensland, Australia Claudia Justino Taborda, Queensland University of Technology, Australia Mark Taylor, University of Newcastle, Australia Goran Vodicka, University of Sheffield, United Kingdom Bing Wang, Beijing University of Civil Engineering and Architecture, China Margaret Ward, Griffith University, Australia Katharine Willis, Plymouth University, United Kingdom Zhen Xu, Nanjing Forestry University, China Yannis Zavoleas, University of Newcastle, Australia Izak van Zyl, Cape Peninsula University of Technology, South Africa Parisa Ziaesaeidi, Erfan Institute of Higher Education, Iran 


\section{FOCUS AND SCOPE}

The Journal of Public Space is the first, international, interdisciplinary, academic, open access journal entirely dedicated to public space.

Established on a well-consolidated global network of scholars and professionals, The Journal of Public Space is committed to expand current scholarship by offering a global perspective and providing the opportunity for unheard countries to speak up and to discuss neglected as well as emerging topics that are usually sidelined in mainstream knowledge.

The Journal of Public Space is addressing social sciences and humanities as a major field, and is interested also in attracting scholars from several disciplines. It will perform as a scholarly journal but also as an interdisciplinary platform of discussion and exchange by scholars, professionals, organizations, artists, activists and citizens, whose activities are related to public space.

The Journal of Public Space will be enriched by hosting papers on design projects, art performances and social practices, fostering civic engagement and non-expert knowledge.

\section{TOPICS}

Authors are welcome to submit original research articles dealing with themes relating to the vision of the journal, which may include, but are not confined to:

$\begin{array}{lll}\text { SPACE } & \text { SOCIETY } & \text { SYSTEMS } \\ \text { Architecture } & \text { Gender } & \text { Economy } \\ \text { Urban Planning } & \text { Human scale } & \text { Political power } \\ \text { Urban Design } & \text { People } & \text { Governance } \\ \text { Urban Morphology } & \text { Everyday life } & \text { Law and regulations } \\ \text { Urban Resilience } & \text { Social engagement } & \text { Public policies } \\ \text { Landscape architecture } & \text { Health and safety } & \text { Private sector/interest } \\ \text { Interior design } & \text { Perception and senses } & \text { Developing countries } \\ \text { Interactive and visual design } & \text { Human rights } & \text { Management and } \\ \text { Art } & \text { Social justice } & \text { maintenance } \\ \text { City transformation } & \text { Education } & \text { Digital/Virtual world } \\ \text { Infrastructure } & \text { Heritage } & \text { Technology } \\ \text { Environment } & \text { History } & \text { Media } \\ \text { Ecology } & \text { Culture } & \text { Third sector } \\ \text { Climate change } & \text { Geography } & \text { Decision-making process } \\ & \text { Anthropology } & \\ & \text { Ethnography } & \\ & \text { Community empowerment } & \\ & \text { Migrations } & \\ & \text { Conflicts } & \\ & \text { Inclusion/Exclusion } & \\ & \text { Informality } & \\ & \text { Sub and fringe cultures } & \\ & & \end{array}$




\section{POLICIES}

\section{Peer Review Process}

A double blind peer review process, based on a distinguished board of editors and editorial advisors, ensures the quality and high standards of research papers. Each paper is assessed by two reviewers and any identifying information in relation to the author is removed during the review process. Reviewers follow an evaluation framework and recommendation guidelines to ensure objectivity and fairness.

Submitted articles should not have been previously published. If publication or dissemination through presentation has occurred, then the article should acknowledge this and pay due credit to the original source.

\section{Publication Ethics Statement}

The Journal of Public Space aligns itself with the Committee on Publication Ethics (COPE) best practice guidelines for dealing with ethical issues in journal publishing.

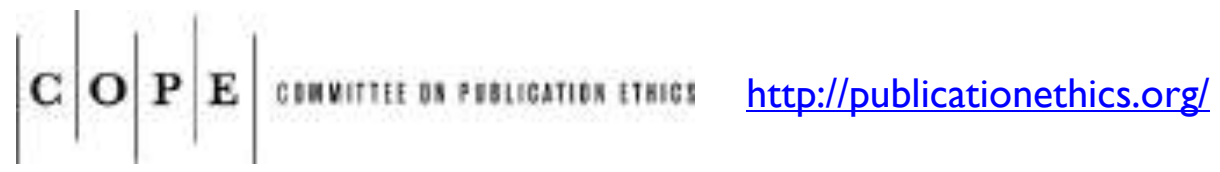

\section{Open Access Policy}

The Journal of Public Space is licensed under a Creative Commons AttributionNonCommercial 4.0 International License. It provides immediate open access to its content on the principle that making research freely available to the public supports a greater global exchange of knowledge.

(c) (1) (3) https://creativecommons.org/licenses/by-nc/4.0/

\section{CONTACT}

\section{Publisher}

City Space Architecture

non-profit cultural association

Via Paolo Giovanni Martini 26/d

40 I 34 Bologna, ITALY

jps@cityspacearchitecture.org

www.cityspacearchitecture.org

\section{Partner}

UN Habitat - United Nations

Human Settlements Program

Nairobi, KENYA

www.unhabitat.org 


\section{Call for papers | 2019 issues}

The Journal of Public Space welcomes full papers for 2019 issues, to be published in April, August and December.

Deadline for April issue: January 10, 2019

Deadline for August issue: May 10, 2019

Deadline for December issue: September 10, 2019

Submissions will be ongoing throughout the year.

Submission can be made:

- using the OJS platform by registering online. If you are already a registered author you can log in using your username and password;

- by sending an email to the Editor in Chief Luisa Bravo at this email address:

jps@cityspacearchitecture.org.

Before submitting, please read:

- the Focus and Scope of the journal

- the Author Guide Lines

Full papers should be between 5.000 and 8.000 words.

https://www.journalpublicspace.orgl 
The Journal of Public Space

ISSN 2206-9658

2018 | Vol. 3 n. 2

https://www.journalpublicspace.org

\title{
Art and Activism in Public Space
}

\author{
Editor \\ Luisa Bravo \\ Guest Editor \\ Maggie McCormick \\ Vol. 3 n. 2 | 2018
}

IN COLLABORATION WITH

BOA MISTURA - PLASTIQUE FANTASTIQUE inCOMMONS + limeSHIFT • ANGÉLICA DASS

RICHARD BRIGGS • FIONA HILLARY

PLANNING INSTITUTE OF AUSTRALIA

CITY SPACE ARCHITECTURE 
The Journal of Public Space | 2018, Vol. 3 n. 2 | Table of Contents

\section{6}

A good collaboration produces universal thinking

Robert Rauschenberg

Cover picture:a Boa Mistura, NIERIKA, Guadalajara, Mexico, 2017.

Graphic Design of this issue: Luisa Bravo

VI | The Journal of Public Space | ISSN 2206-9658 
The Journal of Public Space | 20I8, Vol. 3 n. 2 | Table of Contents

\section{TABLE OF CONTENTS}

\section{EDITORIAL}

Public Urban Happiness, that is the making of our own world Luisa Bravo

The Public Voice

Maggie McCormick

\section{ART AND ACTIVISM}

Art as a tool for change

Javier Serrano Guerra, Juan Jaume Fernández, Pablo Ferreiro Mederos,

Pablo Purón Carrillo

BOA MISTURA

Soft, Sexy, Fantastic. Inflating public space

Daniel Felgendreher

PLASTIQUE FANTASTIQUE

Investing in Spaces: Luxury, Benevolence or Business?

Nabila Alibhai, Yazmany Arboleda, Elizabeth Thys, Tammy Wilks

$75-96$ inCOMMONS + limeSHIFT 
The Journal of Public Space | 2018, Vol. 3 n. 2 | Table of Contents

From sidewalk ballet to defending the city

Maria del Carmen Mota Utanda

HUMAN/E

Using drawing as a tool to explore public space

Richard Briggs

A situated practice

149-166

Fiona Hillary

\section{VIEWPOINT}

Canberra's first ever Parklet

Natalia Weglarz

PLANNING INSTITUTE OF AUSTRALIA

The urban lounge and a green view. A temporary art installation

in Bologna during the Art City White Night

$173-178$

Luisa Bravo

CITY SPACE ARCHITECTURE

VIII | The Journal of Public Space | ISSN 2206-9658 
The Journal of Public Space

ISSN 2206-9658

2018 | Vol. 3 n. 2

https://www.journalpublicspace.org

\title{
EDITORIAL
}

\author{
Public Urban Happiness, that is the making \\ of our own world \\ Luisa Bravo \\ City Space Architecture, Italy \\ luisa.bravo@cityspacearchitecture.org
}

The ideal city stands as one of the most fascinating enigmas of the Italian Renaissance. A famous painting by the same name, consisting of a space nearly empty of human activity, which displays a mastery of perspective, is the result of research and speculation in many fields, from architecture and engineering to philosophy and mathematics. The concept dates at least from the period of Plato: in The Republic, the ideal city, or polis, is based on justice and human virtue, it is a form of social and political organization that allow individuals to maximize their potentialities, living in accordance with universal laws and truths. In this model, public spaces perform as places for collective coexistence, standing as a physical stage for social justice, democracy and citizenship, a sort of mirror of the living society and its values and virtues.

For centuries the urban environment has been painted, designed, shaped and built in order to answer to specific needs and desires. Visions and drawings of ideal and perfect places still today behave as appealing images, offered to the public domain. During the last century, well-known icons, made of visionary and seducing scenarios, designed by avangarde architects, acted as a vehicle able to symbolize the pursuit of public happiness: working on an urban imaginary, as a body of knowledge, efforts of architects and town planners were oriented to create a new world, based on ideals of progress and prosperity, with streets, squares, architectural complexes and housing estates for our everyday lives, for a wide satisfaction and consumption of urban users. In these visions, the city is not merely a geographical episode, it is actually a model of morality, it is a collective entity pictured as a real holistic subject, an organism endowed with an identity and will of its own, with a superior order in comparison to every single member. Especially in the European culture, the beauty of the city reflects the primary social purpose which is the making of urbs, intended as the appropriate habitat for the civitas, open, dynamic, democratic and egalitarian (Romano, 1993).

Far from utopias, the real world hasn't developed the ability to grant all wishes, often revealing itself unable to find a way to connect innermost emotions of collective expectations to the outward manifestation in the urban realm. Even in their imperfections, cities expanded beyond what anyone could have imagined, sprawling along territories, scattering over the known borders (Bravo, 2010). 
In our contemporary times, the image of the ideal city is undefinable: the economic and financial crisis, new forms of urban and religious conflicts, problems of social cohesion, conditions of discrimination and insecurity, the massive immigration, the rise of poverty in the middle class and the large protests in many public spaces around the world have produced urban scenarios based on contradictory, unpredictable and uncertain circumstances. Today the city is mostly a place of conflicts and contraddictions where bold activists are standing up against the consolidated power, spreading awareness and shaping new ideals and values: they defend political issues, human and democratic rights, struggle to preserve the uniqueness of specific places, push governments on urgent questions. Their aspirations, as open-minded citizens, can be seen as a right for freedom of expression and search for self-empowerment. The right to the city is far more than the individual liberty to access urban resources: it is a common right to change ourselves by changing the city.

«The freedom to make and remake our cities and ourselves is one of the most precious yet most neglected of our human rights»

David Harvey, 2008: 23

Likewise, artists are more and more exploring the public domain, searching for stories of people and places, shaping a new human-centred knowledge: they play with the individual urban imaginary, searching for interaction, exchange and emotional engagement, so that from a single statement they can shape a collective belief. Therefore, public happiness is no longer a static concept related to the built environment, it is more a dynamic, vibrant and ephemeral condition that permeates urban daily life.

Daniel Kahneman, the Noble Prize for Economics (2002) has established an interesting and emerging field of research called 'science of happiness'. Working on evolving concepts, such as 'subjective well-being', 'life satisfaction' and 'quality of life', learning by the pioneering political experience (started in 197I) of the small State of Bhutan - based on equitable social development, cultural preservation, conservation of the environment and promotion of good governance - and adopting the goal of Gross National Happiness over Gross National Product, the science of happiness, mainly related to sociology, psychology and anthropology, is starting to influence researchers involved in the urban field of study'. By applying it to urban daily life and then retrofitting our cities to happiness, we can tackle the urban challenges of our age (Montgomery, 20I3).

The first World Happiness Report, published in 2012, was commissioned for a United Nations Conference on Happiness, under the auspices of the UN General Assembly, with the imprimatur of Columbia University's Earth Institute and the editing of the institute's

\footnotetext{
${ }^{\prime}$ As a part of a research activity, in 2012 I myself promoted a survey intended to understand how people live in the urban context, in terms of housing, working and leisure, how they experience, every day, space and distance in the city where they live, how they create relationships with other people living in the same neighbourhood or in the same city. Also, the survey is intended as a tool, able to show if issues expected from urban and town planning design were succeeded, through evaluation and comments derived by common people. Well-designed neighbourhoods and efficient cities, in terms of walkability, public transportation, long-distance connections, urban spaces, public facilities, mixed-use density, should make people happy. The assumption is that happiness of urban communities, together with best-planned settlements for urban daily life, should be the main goal of the urban planner and designer (www.bravodesign.it/urban_survey.html).
} 
director, Jeffrey Sachs, with two happiness experts, Richard Layard of the London School of Economics and John Helliwell of the University of British Columbia. The General Assembly of the United Nations in its resolution 66/28I (20I2) has recognized the relevance of happiness and well-being as universal goals and aspirations in the lives of human beings around the world and the importance of their recognition in public policy objectives. Speaking at the High Level Meeting on "Happiness and Well-Being: Defining a New Economic Paradigm", during the sixty-sixth session of the General Assembly (20II) the Secretary Ban Ki-moon stated that the world "needs a new economic paradigm that recognizes the parity between the three pillars of sustainable development. Social, economic and environmental well-being are indivisible. Together they define gross global happiness."

In this issue 'Art and Activism in Public Space', Vol. 3, n. 2, of The Journal of Public Space we are starting a dialogue with artists and activists that are changing the way we understand and experience the built environment, through creative and inspiring works. This issue is intended to be the first of a series, aimed at opening to a different urban dimension, addressing dreams and public happiness, exploring the invisible, the intangible and the ephemeral in the public domain, that comes after an art performace or a collaborative DIY urbanism and that is able to built a new urban consciousness.

I invited several artists and art collectives, Boa Mistura from Spain, Plastique Fantastique from Germany, inCOMMONS from Kenya and limeSHIFT from USA, Angélica Dass from Brasil, Richard Briggs and Fiona Hillary from Australia. I then invited Maggie McCormick, former Head of the Master of Arts (Art in Public Space) at RMIT University in Australia, to co-curate this issue. By reviewing artists' work, by reading their approaches and statements, I was able to expand my understanding and to open to a world made of passionate devotion and powerful commitment, while the theoretical exchange with Maggie McCormick set the research context.

This issue marks also a new direction of The Journal of Public Space: City Space Architecture is the new publisher since the journal has recently moved from Australia to Italy. As we conclude our collaboration with the Queensland University of Technology, that supported the establishment of the journal in 2015, we are opening to new contents: we are interested to enrich the discussion around public space, engaging multiple voices and expertise, searching for transdisciplinary innovation. The journal will continue to publish peer reviewed articles and academic research, but will also open to different opportunities to understand and redefine theories and concepts, with practicioners, artists, activists and open-minded citizens, especially from the global South, as this is our mission and one of the pillars at the basis of our collaboration with UN-Habitat, the United Nations Human Settlements Programme.

With this issue I'm officially taking the role of Editor in Chief of The Journal of Public Space, I feel proud and honoured to lead this ambitious endeavour and grateful for the interest and the attention that the journal is attracting. The journey has just begun.

\footnotetext{
${ }^{2}$ The General Assembly of the United Nations in its resolution 66/28I of 12 July 2012 proclaimed 20 March the International Day of Happiness. More info at: https://www.un.org/development/desa/dspd/internationaldays/international-day-of-happiness.html. Accessed August 15, 2018.
} 


\section{References}

Bravo, L. (20l0), Genius loci and genius saeculi: a sustainable way to understand contemporary urban dynamics, 14th International Planning History Society (IPHS) conference proceedings, Urban Transformation: controversies, contrasts and challenges, ITU - Urban and Environmental Planning and Research Center, Istanbul, Vol. II, Pp. 543-554.

Harvey, D. (2008), The right to the city, in New Left Review, vol. 53, Sept-Oct, pp. 23-40.

Montgomery, C. (20I3), Happy city. Transforming our lives through urban design, Ferrar, Straud and Giroux, New York.

Romano, M. (1993), L'estetica della città europea, Einaudi, Torino.

\section{To cite this article:}

Bravo, L. (20I8). Public Urban Happiness, that is the making of our own world. The Journal of Public Space, 3(2), I-4, DOI 10.32891/jps.v3i2.1 III6

This article has been accepted for publication in The Journal of Public Space. Please see the Editorial Policies under the 'About' section of the journal website for further information.

cc) (4) (8) This work is licensed under a Creative Commons Attribution - Non Commercial 4.0

International License https://creativecommons.org/licenses/by-nc/4.0/ 
The Journal of Public Space

ISSN 2206-9658

2018 | Vol. 3 n. 2

https://www.journalpublicspace.org

\title{
EDITORIAL
}

\section{The Public Voice}

Maggie McCormick

Adjunct Professor, RMIT University, Australia

Professor, Reutlingen University, Germany

maggie.mccormick@rmit.edu.au

\begin{abstract}
The Public Voice discusses art and activism in public space through the lens of how art practice is re-territoralising public space. The article begins with a consideration of both commissioned and uncommissioned works that challenge male dominance of public space while retaining a traditional relationship between the artist, art and the public. Through a discussion of 'relational' public practices from Relational Aesthetic to Community Art to Social Engagement, the article argues that the kind of 'relational' art and activism undertaken by the collectives, teams and individuals featured in this issue of The Journal of Public Space is linked by spatial practice as a conduit for social change. By framing their practice through a discussion around her own spatial public practice over time, the author emphasises the impact of urbanisation and digitalisation on the changing nature of public space and the public and how the public voice can be mapped through art and activism.
\end{abstract}

Keywords: public space voice, art, activism, urban, spatial, relational, mapping

To cite this article:

McCormick, M. (2018). The Public Voice. The Journal of Public Space, 3(2), 5-I2, DOI 10.3289I/jps.v3i2.11 07

This article has been accepted for publication in The Journal of Public Space. Please see the Editorial Policies under the 'About' section of the journal website for further information.

This work is licensed under a Creative Commons Attribution - Non Commercial 4.0 International License https://creativecommons.org/licenses/by-nc/4.0/ 


\section{Activism and Public Space}

Activism can take many forms in public space from large scale public rallies to the individual on their soap box. Activism can be loud or quiet, bombastic or subtle. What links them all as activism is that the action sits outside of the routine of everyday public life. The action aims to disrupt the culture and patterns of public space and reveal it as a space where society's diversities converge, sometimes through the traces left as people negotiate their individual pathways through the space and sometimes through momentary mutual engagement through quick glances and snippets of conversation with a stranger. Art has the capacity to activate interventions in the public domain that interrupt this everyday social rhythm of the space, to create rhythms that question perceptions embedded in that space, and claim it for the society of people who are the public space itself. Art activism creates moments that foster a new voice for public space.

This issue of The Journal of Public Space: Art and Activism in Public Space focuses on the voice of public space activated through the art practice of six collectives, teams and individuals working across a multiplicity of worldwide public spaces - Boa Mistura, Plastique Fantastique, inCOMMONS + limeSHIFT, Angélica Dass, Richard Briggs and Fiona Hillary. Together they form a snap shot of the bigger universal picture of the changing relationship between art practice, public space and the people within that space through a form of activism advocating that 'public space in cities is a common good, meant to be open, inclusive and democratic - a right for everybody' as advocated by Luisa Bravo in her public lecture Stand Up for Public Space.' While global in their interventions and outcomes symptomatic of our time, each activation responds to the specificity of the space they are engaging with, while re-territoralising and re-conceptualising public space, its culture and art activism more generally.

\section{Public Space and Art Practice}

Traditionally public space has been seen as the city square or park land with its relationship to art through permanent monumental sculptures that recorded limited histories and through that process, claimed the space itself for a particular section of society. Today the nature of such art practice within public space is challenged as are the histories and ideologies, perceptions of people and place, traditionally embedded in these works. For example, this has resulted in public debates around the issue of retaining or removing traditional public sculptures that are now viewed as not representative of public views. A clear example of changing attitudes in the midst of such debates is the Fourth Plinth in Trafalgar Square in London UK. ${ }^{2}$ Three of the plinths hold statues of a male British general, a male army officer and a male royal. The fourth was also destined to hold a male royal but was held over due to lack of funds. A lucky misfortune. The fourth plinth on the square remained empty until around 1998 when a series of three commissioned works occupied the space. It was with the fourth temporary work Alison Lapper Pregnant 2005, a marble torso-bust by Mark Quinn, that the real challenge was made. ${ }^{3}$ While

\footnotetext{
' Luisa Bravo. Stand Up for Public Space, 2017. https://unhabitat.org/stand-up-for-public-space-luisa-bravo/

${ }^{2}$ Fourth Plinth, London UK. https://www.london.gov.uk/what-we-do/fourth-plinth-past-commissions \& https://www.bbc.com/news/uk-england-london-43565870

${ }_{3}^{3}$ Mark Quinn. Alison Lapper Pregnant. http://marcquinn.com/artworks/alison-lapper
} 
monumental in scale like the other three traditional sculptures, this work was of a person who was female, pregnant and born with no arms and shortened legs. Many other works have followed occupying the Fourth Plinth as a challenge to the historical symbolism of the public space of Trafalgar Square itself. A more detailed discussion around the public place that is Trafalgar Square can be read in Shanti Sumartojo's The Fourth Plinth: creating and contesting identity in Trafalgar Square, 2005-2010. ${ }^{4}$

While the Fourth Plinth example fall within officially accepted and commissioned challenges to the status quo, reflective of changing times and attitudes, other public activations are sometimes anonymous, unsanctioned and even illegal. One example of both commissioned and uncommissioned street works, symptomatic of the growing presence of strong female imagery in the public domain, are the paper paste ups of a Melbourne based street artist, Baby Guerrilla. ${ }^{5}$ Large scale black and white paste ups defy gravity and the assumptions of the space as they fly across that space and appear unexpectedly overnight on Melbourne's streets and laneways. Amongst others, Vexta and Swoon are two other women artists working in the public space of streets and lanes. Together they pose a re-territoralising of public space, as did Alison Lapper Pregnant in Trafalgar Square as a reclaiming voice that challenges white male dominance of these public spaces. Swoon sums this up by asking, 'Have we approached a tipping point in society, where, informed by the input of creative women, we begin to rewrite social narratives for the better?' in Roland Henry's Meet the Women Redefining Street Art. ${ }^{6}$

These examples taken from city squares and streets can be seen as disruptions to the accepted culture of specific public spaces and as such, a form of activism through art practice. While the outcomes create arrhythms in the social pattern of the space, the practice conforms to traditional modes of art making, in that people within the public space are seen as the audience, as observers. Many artists working in the public domain challenge this role of the public as observer. This is clearly evident in the public practice of all the artists included in this issue of The Journal of Public Space. Whether they work as individuals, teams, collectives or community facilitators, forms of 'relational' practice link their intent and art process. While their outcomes may vary, in one way or another they aim to engage the public beyond the role of audience so that the public and the space become an integral part of the art intervention itself, of the voice.

\section{Relational Art Practice and Activism}

Many people in the art world are familiar with the term 'relational aesthetics' coined by Nicolas Bourriaud in the 1990s to describe the tendency to make art based on, or inspired by, human relations and their social context. ${ }^{7}$ The role of the artist is proposed as a conduit between the audience and the event to create a social experience within a constructed environment. The event itself, what takes place between the participants, is

\footnotetext{
${ }^{4}$ Shanti Sumartojo. The Fourth Plinth: creating and contesting identity in Trafalgar Square, 2005-2010. Sage Journals. 2012. http://journals.sagepub.com/doi/abs/I0.1 I77//4744740I2448304

${ }^{5}$ Baby Guerrilla, http://babyguerrilla.com/ \& https://blog.whodhavethought.com/2014/05/28/interview-babyguerilla

${ }^{6}$ Roland Henry. Meet the Women Redefining Street Art, The Guardian Australia, 8 January 2015. https://www.theguardian.com/artanddesign/2015/jan/07/street-art-women-elle-swoon-vexta

${ }^{7}$ Nicolas Bourriaud. Relational Aesthetics. Les presses du reel, France. 1998.
} 
seen as the work of art. Bourriaud's prime example is the Argentinian born Thai artist Rikrit Tiravanija who in one of his exhibitions cooked Thai food for visitors to the gallery to create an environment in which social exchange took place. The exchange is the art. While Bourriaud's 'relational aesthetics' was substantially referring to such changing practice within the gallery and institutional system, many artists working in the public domain had been working in a 'relational' way for some time, albeit labelled in different ways and often with different intentions. The Community Arts movement can be seen as a forerunner of the relational concept. Here a more traditional art outcome was usual, such as a mural or theatre piece, but the process and interaction between the artist and the public was viewed as equal in value. Early community led public art projects grew out of the idea of art as a democratic right that was very much grounded in a reterritoralising of both art practice and public space. The UK, USA and Australian examples were in this mode. During the 1960s, 1970s and into the 1980s many artists worked collaboratively within a participatory practice model within which art was made by the people themselves. In Melbourne the Community Arts Network embraced this mode of practice that I was a part of, working collaboratively on such large-scale projects as the Curtain Square Playground 1988. Symptomatic of its time the project engaged hundreds of local people in making and installing ceramic tiles that recorded their diverse connections to the Carlton neighbourhood and the creation of the character of its public domain. In this case the public space of the playground became a voice of the people. Other Community Arts Network public projects for example engaged poster art as part of political protest, again as a voice of the people. At the time, these examples were a form of radical activism through participatory democracy that rejected earlier efforts to 'take art to the people' though the model of educating the general public to appreciate the arts within art establishments. Owen Kelly's manifesto Community, art and the state: Storming the citadels $1984^{8}$ was symptomatic of this thinking about the role of art practice, public space, the people and the social and political framework of the times.

While still used as a definition of some practice, the term Community Art has lost its radical edge, its power and meaning in many places over time and we more often now refer to Social Engagement. The practice is diverse in its processes and outcomes and crosses over with concepts of community cultural development, placemaking, participatory art and social practice reflecting back to the social sculpture of Joseph Beuys. While socially engaged art practice defies a straight forward definition, a recent USA report, Mapping the Landscape of Socially Engaged Practice 2017 sets out some definitions. ' Included are 'belief in the agency and responsibility of art and artists' and 'artists working in collaboration'. While the report is somewhat America centric, these definitions do apply to the action of the artists included in this issue of The Journal of Public Space. Artists, architects, engineers, musicians, photographers, dancers, designers and the public are drawn together, as Boa Mistura say in this issue, with a common sense of 'responsibility with the city and the time we are in'. While the quote by William S. Burroughs at the start of the report may be debatable that 'Artists are the real architects

\footnotetext{
${ }^{8}$ Owen Kelly. Community, art and the state: Storming the citadels. Comedia, UK. 1984.

${ }^{99}$ Alexis Frasz \& Holly Sidford. Helicon Collaborative. Mapping the Landscape of Socially Engaged Practice. 2017. http://artmakingchange.org/wpcontent/uploads/2017/09/Mapping_the_Landscape_of_Socially_Engaged_Artistic_Practice_Sept2017.pdf
} 
of change, not the political legislators who implement change after the fact', creative activators within public space certainly play a pro-active part. While the report discusses how every major social movement throughout time has integrated art and activism, what is missing is consideration of the role of the space itself as a key component of art as activism in today's context.

\section{Spatial $=$ Social Practice}

What defines all included in Art and Activism in Public Space beyond most public practice loosely defined as Socially Engaged, is their direct 'relational' action with the public space itself, its building, objects and atmosphere, as a conduit to social inclusion and change.

This includes not only the practice of the collectives, teams and individuals featured in this issue but also to the projects the viewpoint - Canberra's first ever parklet by Natalia Weglarz and The urban lounge and a green view by Luisa Bravo. Both discuss the social impact of spatial interventions that re-interpret the parking space within the city environment.

All aim to reveal the public voice of the space in order to reveal its social voice. Each in their own way is engaged in spatial transformation, most often ephemeral, as an integral part of their social practice. Through this spatial practice each aims to foster shift and change through dialogue and challenge current social paradigms and in the process create a re-territorialisation of public space. This may well be reflective of their own diverse backgrounds, so that a multiplicity of arts, architecture and design inform each other to create a particular kind of urban practice responsive to the city itself. Cities have become central to our understanding of public culture and through this, an understanding of ourselves.

In this issue on Art and Activism in Public Space Boa Mistura redefine the power of the materials of art making and talk of promoting 'change through colour' though the paint's direct 'dialogue with the place' and how 'a layer of paint of barely a few millimetres thick can change the perception that a whole neighbourhood has of a place'. Richard Briggs also uses the material of art making to transform the space though, in his case, drawing materials. Through immersing himself in the cityscape and observing the people, buildings and objects that occupy that space his 'urban sketching' records multiple perceptions of a space. As he says, 'This approach to documenting the city can then be used to canvas a wider discussion on our built environment' and by default a rethinking of the possibilities of our shared public space. Like Richard Briggs, Plastique Fantastique address the built environment of public space. They use a sense of play to create a new surprising interface between the built environment of the space and its public. Through the introduction of ephemeral soft inflatable architecture into public space the space itself is challenged by what they call 'bewildering activities' of the new architectural interventions 'squeezing between buildings, squashing under bridges, entwining around lampposts or trees.' Notions of pleasure in public space also informs the workspace practice of inCOMMONS + limeSHIFT. They say, 'spatial transformation shifts the way people experience and engage'. When the space changes, social and cultural perceptions change. Imagination and possibilities enter the picture and as Fiona Hillary says, 'allow artists and audience to coconstitute the possibility of something other, triggering fleeting transformative acts of imagination'. Angélica Dass uses photography to explore and search out diverse identities 
through diverse colours across the portraits. The process reveals and asserts layered histories and cultures within the public domain through using the camera as a catalyst for a flow of dialogues in the space of streets. In the process people bring the space alive.

\section{Public Space Culture and Urban Practice}

Combined together, the voice of the public spaces these collectives, teams and individuals work in supports an important field of urban thinking that re-shapes public space culture. I describe this as a growing sense of urban citizenship or 'urbaness', a term I coined in my $\mathrm{PhD}$ thesis 2009 to describe a sense of being urban, being connected. ${ }^{10}$ In a rapidly urbanising world situated in a rapidly digitalising world it is important to activate public space in such a way that diverse voices shape our vision of the future. Fiona Hillary quotes Rosi Braidotti on this. Braidotti says, 'Whatever increases your capacity to act and intervene in the world - intervene in the public sphere - for the love of the world'." This reinforces the perspective of Luisa Bravo and Valerio Francia, City Space Architecture, when they say in relation to the 'We the People, We the Public Space' exhibition, the intention was 'to stress the concept that people and public space, intended as the space for democracy, social justice and equity, are strongly intertwined, so that talking about people is the same thing as talking about public space'. This can be extended to say that talking about public space is the same thing as talking about people - talking about public urban culture. All is reflected in the United Nations' campaign 'We the people' for the Global Goals launched in 2015 and the UN commitment 'Leaving no one behind' 2016 and 2017 for inclusive development quoted by Luisa Bravo.'2

This Overview is written in this context and framed by the perspective of many years of urban practice in and about public space, engaging in public culture as an artist, curator and academic researcher. As current Adjunct Professor and in my former role as Head of the Master of Arts (Art in Public Space) at RMIT University, Australia, I have published and presented on public space culture many times. My perspective on art and activism in public space has been shaped by my early innovative city space interventions in Melbourne from 1990 to 2006, as an artist and curator in public space that laid the groundwork for others to follow. In 1990 five important factors coincided - an economic downturn; artists' disillusionment with the commercial gallery system; a growing awareness of a new role for art in public space reflected in the City of Melbourne's fostering of art practice in the public domain; a general emerging understanding of the impact of urbanisation and digitalisation on art and activism. The economic downturn left many shop fronts and buildings in prime locations, empty. Combined with disillusionment with the commercial gallery system, the scenario opened up my interest in nonconventional city spaces as spaces for art action. Supported by the City of Melbourne and

\footnotetext{
${ }^{10}$ Maggie McCormick. The Transient City; mapping urban consciousness through contemporary art practice. Unpublished PhD thesis. Faculty of Architecture, Building and Planning, The University of Melbourne, Australia. 2009.

11 Rosi Braidotti. The First Supper Symposium paper. 2014. https://www.youtube.com/watch? $=$ BXbx_P7UVtE

${ }^{12}$ Bravo L. and Francia, V. (20I8). We the people, We the public space. An interactive exhibition at the 9th World Urban Forum. The Journal of Public Space. 3 (I), pp. 153-162. doi: https://doi.org/I0.5204/jps.v3il.325. https://www.journalpublicspace.org/article/view/325
} 
the National Association for the Visual Arts, I initiated No Vacancy in over ten empty shop fronts in one of Melbourne's prime city street and square locations on Collins and Swanston Streets. Over time the No Vacancy 1990-1994 concept grew to become urbanart that ran to 2006 and included claims on multiple public spaces across the city as locations for non-conventional art interventions. These included advertising panels at city tram stops, first floor windows, public stairwells and even a twelve-story empty building. I was not aiming to place conventional art in public space as alternative galleries, rather works designed by myself and others aimed to engage with the space itself and in particular with the reflective surface of glass windows and panels. The relationship between art and public was intertwined in this 'in-between' space to create a very different kind of active public art than the until then more familiar static public sculpture in the streets of Melbourne. Through the urbanart practice I went on to draw together global public city space through projects like Kultural Kommuting 1998 that linked public transport and public stairwell spaces in Berlin and Melbourne; melbourneconnectionasia 2004 that linked Melbourne public transport shelter spaces with gallery and artist run spaces across eight Asian cities; Global Fusion 2002 and Global Fusion Close Up 2006 that linked public spaces in Vienna and Melbourne. ${ }^{13}$ Experiences such as these heightened my awareness of the significance of public space and the power embedded in spatial art practice across global public space and people. My practice through urbanart while emerging out of the public space of Melbourne, took a global focus on urban space and the relationship of art practice to public space culture and urban identity by creating dialogues through establishing spaces for cultural translation amongst artists and between artists and the public.

The evolution of my public space practice from No Vacancy to urbanart paralleled the City of Melbourne's growing awareness of contemporary modes of art practice in public space that began with permanent contemporary works installed as Swanston Street Walk, to On Site with a series of temporary works installed in prime city public locations. The On Site catalogue 1990 sets out the intention of the works to 'explore, challenge, enhance and transform our interpretation of the city'. The key word here is - 'transform'. The power of temporary installations integrated into the fabric of the city itself became the City of Melbourne's mantra over many years as the Melbourne Laneway projects 200I - around 2010 and was adopted by the City of Sydney 2008-2013 and others. ${ }^{14}$

\section{Mapping the Public Voice}

My interest in public space is currently around the public space culture of Skype, the impact of mediation of digital screens on urban identity and what role art practice plays in shaping and mapping this. The connectedness of urban public space and a common sense of being urban, or what I call 'urbaness', brought about through urbanisation and digitalisation, is now a key factor in my artistic and curatorial practice in public space in particular through the lens of the co-curated project SkypeLab (2014 ongoing) and its

\footnotetext{
${ }^{13}$ urbanart. National Library of Australia. Pandora Australia's Web Archive. http://pandora.nla.gov.au/tep/2I443

${ }^{14}$ City of Melbourne does not hold an online archive. City of Sydney. Laneway/City Spaces. http://www.cityartsydney.com.au/projects/lanewaycity-spaces/
} 
predecessor, Skypetrait (2012-2013). ${ }^{15}$ I wrote about these concepts in more detail in Skypeography. Investigating and mapping the public mind space of urbaness in The Journal of Public Space 2018. ${ }^{16}$ I discuss how mediation by screens is creating new urban concepts across an emerging new spatial geography and its emerging sociologies and cartographies. Unlike my earlier public space practice, my current artistic and curatorial practice is primarily a mapping practice recording my urban cartography through works with titles such as MelBeiVien, MelShangLingen and MelLingen. ${ }^{17}$ Each records my personal voice through the interconnected urban public space culture of Vienna, Beijing, Shanghai, Reutlingen and Melbourne. My voice can be seen as one amongst many diverse voices. While the voice of the collectives, teams and individuals in this issue of The Journal of Public Space: Art and Activism in Public Space is present in their practice, they do not specifically set out to address their personal voice but rather use their spatial practice to draw out the diverse, common or universal voice. While they are not engaged directly with the new digital public space, their physical activations expand across a network of global spaces, mapped through their web presence and in the process create a global cartography of the re-territoralising of the public voice through art and activism.

\footnotetext{
${ }^{15}$ Maggie McCormick and Henning Eichinger. Skypetrait and SkypeLab. www.skypelab.org

${ }^{16}$ McCormick, M. (2018). Skypeography. Investigating and mapping the public mind space of urbaness. The Journal of Public Space, 3 (I), pp. 3-12. doi: https://doi.org/I0.5204/jps.v3il.315. Abstract https://www.journalpublicspace.org/article/view/315 \& article https://www.journalpublicspace.org/article/view/3/5/303

17 Maggie McCormick. MelShangLingen and Mellingen can be viewed on pages 42-45 and pages 64 and 65. SkypeLab: transcontinental faces and spaces. Kerber. Germany, USA, 2016. http://www.skypelab.org/publication/
} 
The Journal of Public Space

ISSN 2206-9658

2018 | Vol. 3 n. 2

City Space

https://www.journalpublicspace.org

Art as a tool for change Javier Serrano Guerra, Juan Jaume Fernández, Pablo Ferreiro Mederos, Pablo Purón Carrillo

Boa Mistura

hola@boamistura.com

\begin{abstract}
Each of the more than twenty countries in which we have worked represents a unique experience that has made us learn and gradually generate a participatory methodology in which we involve communities not only in the design process but in the execution of a urban art piece. More than fifteen years of work with the aim of humanizing the city and generating great changes from simple artistic activities.
\end{abstract}

Keywords: urban art, change, participation, inspiration, identity

To cite this article:

Guerra, J. S., Fernández, J. J., Mederos, P. F., Carrillo, P. P. (2018). Art as a tool for change. The Journal of Public Space, 3(2), I3-40, DOI I0.3289I/jps.v3i2. I 108

This article has been accepted for publication in The Journal of Public Space. Please see the Editorial Policies under the 'About' section of the journal website for further information. 
More than fifteen years have gone since we painted our first murals on the streets of our neighbourhood in Madrid to this day, freshly landed back in Madrid from the $9^{\text {th }}$ World Urban Forum in Kuala Lumpur. Much learning and personal evolution separate us from our first works. When, at the end of the $90 \mathrm{~s}$, we got together in our neighbourhood in the outskirts of Madrid to paint graffiti, we could never have imagined the many experiences that we would have the opportunity to live around the world, thanks to it. Our trip started in a very spontaneous way, while we shared our free afternoons as high school students. Graffiti was our common point and the way we had fun. A few years later, each of us followed a different path in college. We are formed as Artists, Advertisers, Architects and Civil Engineers, but always finding time to get together to paint in the street, being more and more aware of how much we liked that.

When we finished our university studies, climbing on a crane painting twenty five meters above ground in Berlin, we made the decision to join forces to devote ourselves completely to what we liked the most. We rented a small studio space in the heart of Madrid, which is still our refuge today. Little by little, the first job opportunities began to emerge, and we took 'Boa Mistura' as the collective name. For us, this Portuguese word meaning 'good mix' represents the loss of each one's personal ego. Boa Mistura is the union of our abilities and interests always in favour of a common result.

We began to dedicate every hour in the day, and every day of the week, to designing and painting, maturing and evolving different lines of work, feeling more and more comfortable with the job we created. In 20 II, an opportunity came to us that changed our way of understanding our work forever: we were invited by Ricky Lee Gordon, gallery owner and South African urban artist to make an artistic residency in Cape Town. There we had the opportunity to know the township of Khayelitsha, one of the largest slums in South Africa, inhabited by some 400,000 people in very basic metal houses. It was the first time we faced a reality like that. Despite the need, the shortcomings and the social problems, we were fascinated by the strong sense of unity and community of those people.

There we were able to intervene in the barracks of the Velokhaya cycling school, a cultural and sports centre that has become a refuge for many young people in the community, helping them to escape from their complicated family situations.

Amos, the founder of the school and a natural-born community leader, encouraged all of the students to participate in the painting process. This was the first time we opened our working process to other people. We painted accompanied by dozens of kids and neighbourhood volunteers. It was a real turning point in our career: we realized that when people participate personally in the process of transformation of the place they live, they begin to feel proud of it. If they are able to change their environment, why not change other negative aspects that surround their lives?

They told us in the Woodstock neighbourhood:

"Changes, however small, can generate big changes. Maybe it's your job. What you are going to do here, can be the spark that ignites this great change".

This is how the Crossroads project was born.

From then on, and whenever possible, we consciously try to include the local community of the site in our work methodology, both in the process of collecting ideas for design 
and in the execution. In addition, we often elaborate more than one proposal so that they are the ones who choose by voting which of them will be the one that is finally executed. For us, it is not only about sensitizing the inhabitants, it is also about being transparent and generating a participatory process both in the identification and in the formulation of the work.

Since we passed through South Africa, we have visited more than 20 countries putting into practice what we have learned, learning new things and adding new layers to our work: from the favelas of Sao Paulo in Brazil, to the overpopulated cities of China; from the narrow lanes of the Casbah (old city) of Algeria to the arid boundaries of the Atacama desert in Antofagasta, Chile; from Bogotá, the massive hives inhabited by displaced people of the armed conflict of Colombia to the blocks of the periphery of Guadalajara, in Mexico. Each of these places have represented a unique and completely new experience, but at the same time we find that there is a discourse that unites the lives of all the people who inhabit them.

Each of those places has told us a story of overcoming and courage, the story of people in the most vulnerable situations and often forgotten by institutions, who struggle every day to build a community and protect their values. We, through our work, simply try to reinforce their identity and promote change through colour, but it is always us who take the greatest learning. Now we know that everyone, regardless of where they were born or what their life is like, has an enormous potential inside that deserves to share with the world. We call it "the diamond inside", once again, taken from the learning that our experience in South Africa implied.

We have understood that in our work, when living in the street, the human factor is something of capital importance.

We seek inspiration in people, to generate works that in turn inspire others and thus, in a kind of loop, humanize this world in which we live.

We use painting as a tool to dignify the space and completely modify the urban landscape, giving it a new story. We find paint interesting as a work tool because of its enormous evocative power and the immediacy of results. There is no quicker and simpler way to completely alter a place. It is universal and accessible to everyone. No specific training is needed to apply it, and it has a very playful nature, so it is a perfect tool to stimulate participation in our projects.

One of the things that we preserve from our roots in the world of graffiti is the perception of the street as the best scenario in which we can intervene: it is a free space, spontaneous and constantly changing. In the street there are no intermediaries between the receiver and the art piece. For us, urban art in the city is no more than a reflection of a healthy society that knows how to express its ideas in a creative way. That is why we are attracted by the idea that our works are part of the public space, we want to add our point of view to the common story of our time.

After several years working in the street we have realized that often, the way in which the planning of new urban infrastructures is addressed is not usually very sensitive to the urban fabric in which it is inserted. This has resulted in urban barriers, residual zones and areas of marginality.

For us, being able to live in a friendly and humanized environment is a right for all and that is why we focus precisely on those points of conflict and stigmatization. We want to make the city a place of interaction, at the service of people and with the ability to convey a 
message of empowerment and optimism. We have to be aware that the aesthetics of everything around us influences our lives and our state of mind.

The noise, the smells, the speed, the culture and the overdose of stimuli are implicit concepts in the life of the cities. We take all that information and use it as a creative base to play and generate a beautiful message.

"If you live surrounded by trash and dirt, that's what you will feel inside you".

Another lesson we take from Cape Town.

The permanence in time does not worry us, we assume that it is something characteristic of urban development. The ephemeral nature of art seems beautiful and romantic to us, it flows with the history of spaces. Our work is alive, and like any living being, it is born, ages and ends up dying.

For us the most important thing is that the work is connected in some way to the specific enclave, so that it only makes sense there. Therefore, before starting to sketch the design, we do a previous research work to immerse in the place, the culture and the people that make up the community where the work will remain anchored. We like that it is the locals themselves who give us their perspectives of the context and from here we start to build a work that is coherent with all that wealth. We try that the final result articulates a dialogue with the place and the people who will live with it.

Sometimes we underestimate the capacity for transformation of small actions, but a layer of paint of barely a few millimetres thick can change the perception that a whole neighbourhood has of a place, and that is something we have learned from experience. A good example of this was our visit to Hamar, in Norway, where we intervened in I 200sqm of pavement used as parking to reclaim it as a space for people. We were inspired by the Scandinavian fabric prints, which the Norwegians wore so proud, and we put a jersey in the square. With that spot of colour, the inhabitants of the area began to perceive and use the esplanade as a plaza. Thanks to that first artistic experience, the transition to create a true square in that space, with the help of several groups of architects and town planners, was much simpler.

The same happens with one of our latest works: Nierika, located in the Mexican city of Guadalajara. When we now see that colossal space of colour where children play, it is hard to imagine that just a few months ago it was a degraded and desert place where the sale of drugs proliferated.

We remembered arriving there with empty hands and that immediately the exuberance of the Mexican culture overwhelmed us. The violent colours of its painting, the infinite extension of the cities, the hospitality of its people, its thousands of sounds and flavours and its historical legacy. We wanted to take a bit of all that strength to a space that seemed to have lost its identity. And as always, it was the residents of the Infonavit Independencia neighbourhood that helped us channel all these ideas into three powerful words that we drew on the facades that face the square: FUI, SOY, SERÉ. (I was, I am, I will be). Past, present and future.

As a common thread, we use the iconography of the Wixárica culture, native of northern Jalisco.

The Nierikas are for the Wixárika people trans generational mirrors that allow them to 
communicate with their ancestors to guide their steps in a firm and successful way towards the future.

Therefore, we use shapes and colours inspired by these Nierikas to draw, from the floor of the immense square, the three screaming words in the buildings that surround it, as a call to pride, to keep alive the identity that differentiates us as people, neighbourhood or culture, in the generations to come.

Once the concept of the project was decided, we faced those 4500 sqm with the help of several unemployed residents of the neighbourhood, volunteers from the neighbourhood and several groups of students from the University of Guadalajara. The process provided a unique opportunity for interaction between very different people for several weeks. For that reason only, for us the project has already been a success.

At the end of the execution, that abandoned esplanade has become the new meeting point in the neighbourhood and one important landmark in the city. It is a place where conferences, concerts, flea markets and picnics take place. We said goodbye to the square as proud parents, happy to have been present in that exciting moment of change. It is a work that no longer belongs to us but has a life of its own.

We love what we do.

We do not know how to live in another way. Today, the studio has grown (we are currently seven people in the team) and, with it, the desire to continue giving a spin to that wheel of inspiration that is our job.

We continue working with the same enthusiasm and the same desire as those kids who met on weekends in the streets of their neighbourhood. We continue to learn and get excited in every place we go, so, as long as there is fuel in the engine, we will continue with this adventure called Boa Mistura. 
Art as a tool for change

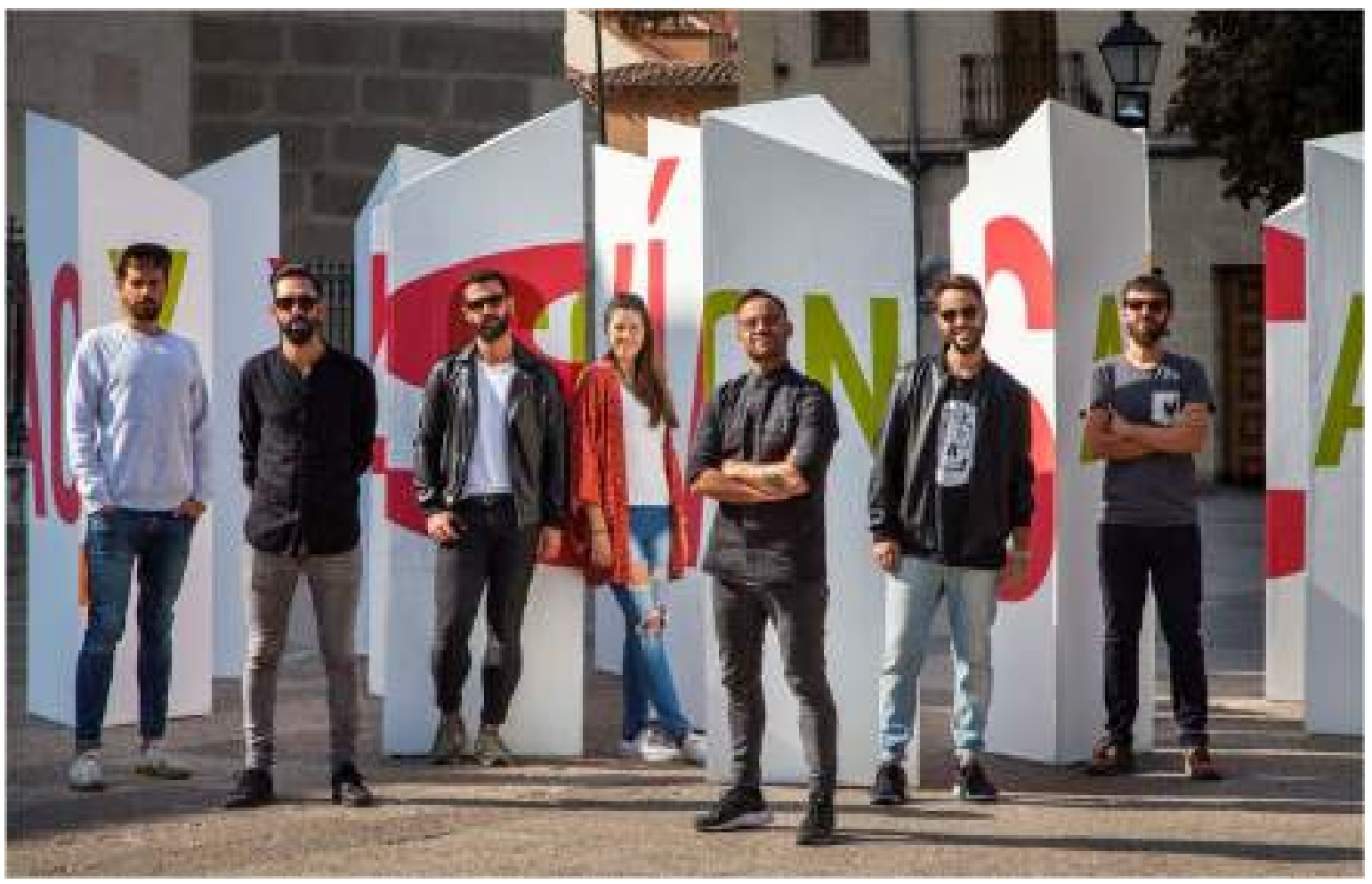

Boa Mistura is a multidisciplinary team with roots in graffiti art. Born in late 200I, Madrid, Spain. The term 'Boa Mistura' comes from the Portuguese 'good mixture', referring to the diversity of backgrounds and points of view from each member. We were fifteen years old when we first met, while painting the walls of our neighbourhood. We became friends since then. We painted our first mural in the late $200 \mathrm{I}$ and in January 2010 we opened our own studio in Madrid, where we work hard with passion and love. We develop our work mainly in the public space. We have carried out projects in South Africa, USA, UK, Brazil, Mexico, Georgia, Chile, Algeria, Norway, Kenya, China, Serbia or Panamá. Our headquarters is in Madrid, but we spend the day from here to there, living among paint buckets, computers and ping-pong matches.

We love what we do. We understand our work, as a tool to transform the street and to create bonds between people. We feel a responsibility with the city and time we are living in.

http://www.boamistura.com 


\section{NIERIKA}

Guadalajara, Mexico. November 2017

http://www.boamistura.com/\#/project/nierika

The housing is located at the north of Guadalajara.

It is estimated to have around 2.500 inhabitants, living in 1.024 apartments, distributed in 66 similar towers. It was built by the Infonavit in the early 80 's and today represents one of the several stigmatized areas of the city, due to the explicit drug dealing problem.

The neighbors tells us that the Municipality has never allocated economic resources to its maintenance. Our perception is that of an abandoned place, with a very complex living dynamic, but with a lot of possibilities to work in order to reverse this dynamic, creating a new usage memory among the neighbors and create appropriation.

The project covers 1000 sqm of the sport courts, while the facades of the buildings are almost $5000 \mathrm{sqm}$, distributed among three buildings, two facades and a huge floor that have become one of the most depressed areas of the Colonia Infonavit Independencia in a large square for neighbors.

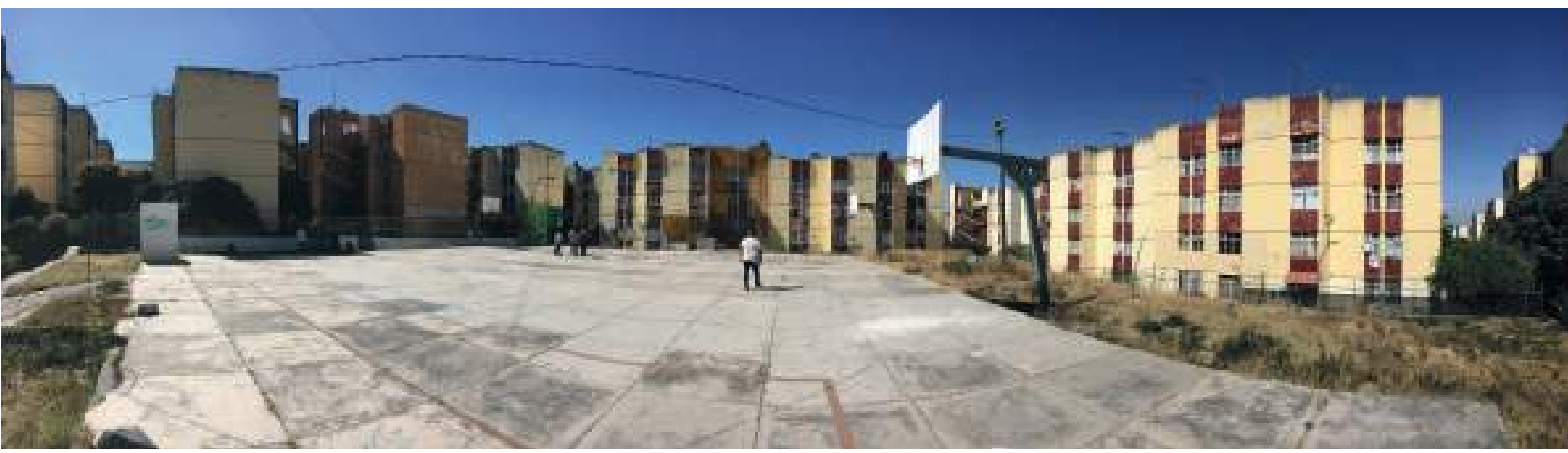

The creation process has included the community since the beginning of the project, in January 2017, through some surveys that inspired two lines of work that were put to a vote among the neighbors, being they themselves who chose what was going to be painted in their place. During the execution, carried out during November 2017, five neighbors were hired in unemployment to be part of the team, in addition to the many neighbors who joined selflessly, as well as students from the University of Guadalajara, who accompanied the process of principle to end.

The work is based on the wixárika worldview, the majority indigenous people in the Jalisco area and the adjacent states. In the wixárika universe, everything is related, everything and everyone is in constant communication. People, plants, animals, the Sun, the air, water, the earth ... all together we are part of the same universe, full of links that unite us with each other. That is why, for this concept of community, by the strength of community bonds to understand the world and by geographical proximity, we have chosen the Wixárika people as inspiration for our work.

The NIERIKA is the transgenerational mirror of the wixaricas. An amalgam of energy that prolongs the wisdom of the ancestors in the following generations, and guide them to build the future. 

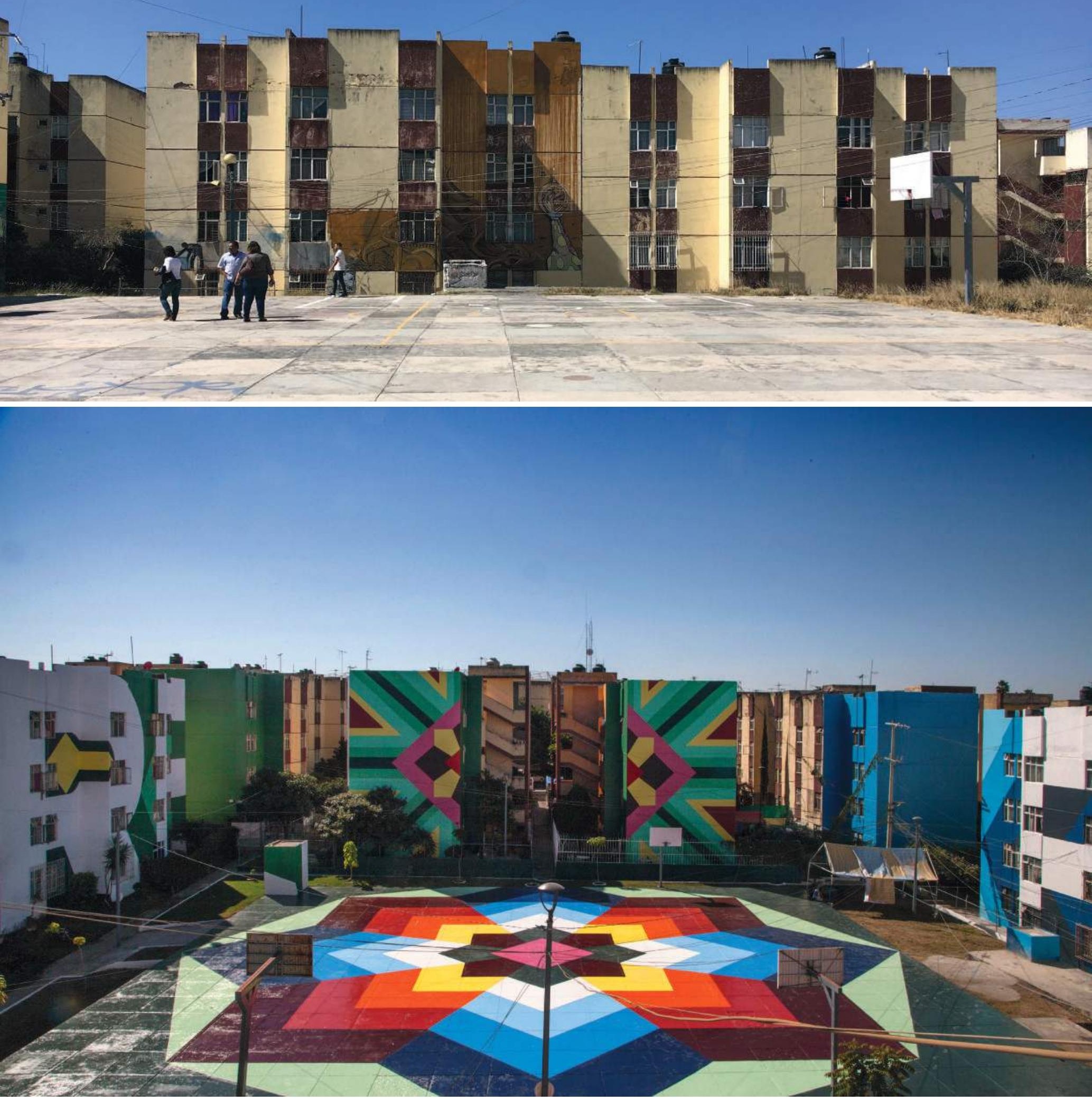

20 | The Journal of Public Space, 3 (2), 2018 | ISSN 2206-9658

City Space Architecture / UN-Habitat 
"The niérika allows the wixaritari to put order in their daily life, to live in unity in a world in which, otherwise, it would be chaotic and unpredictable. It also allows them to relate the present with the past, and, for this reason, it allows them to live with awareness of their history and know that they are the ones who will design their own future."

Luz Chapela

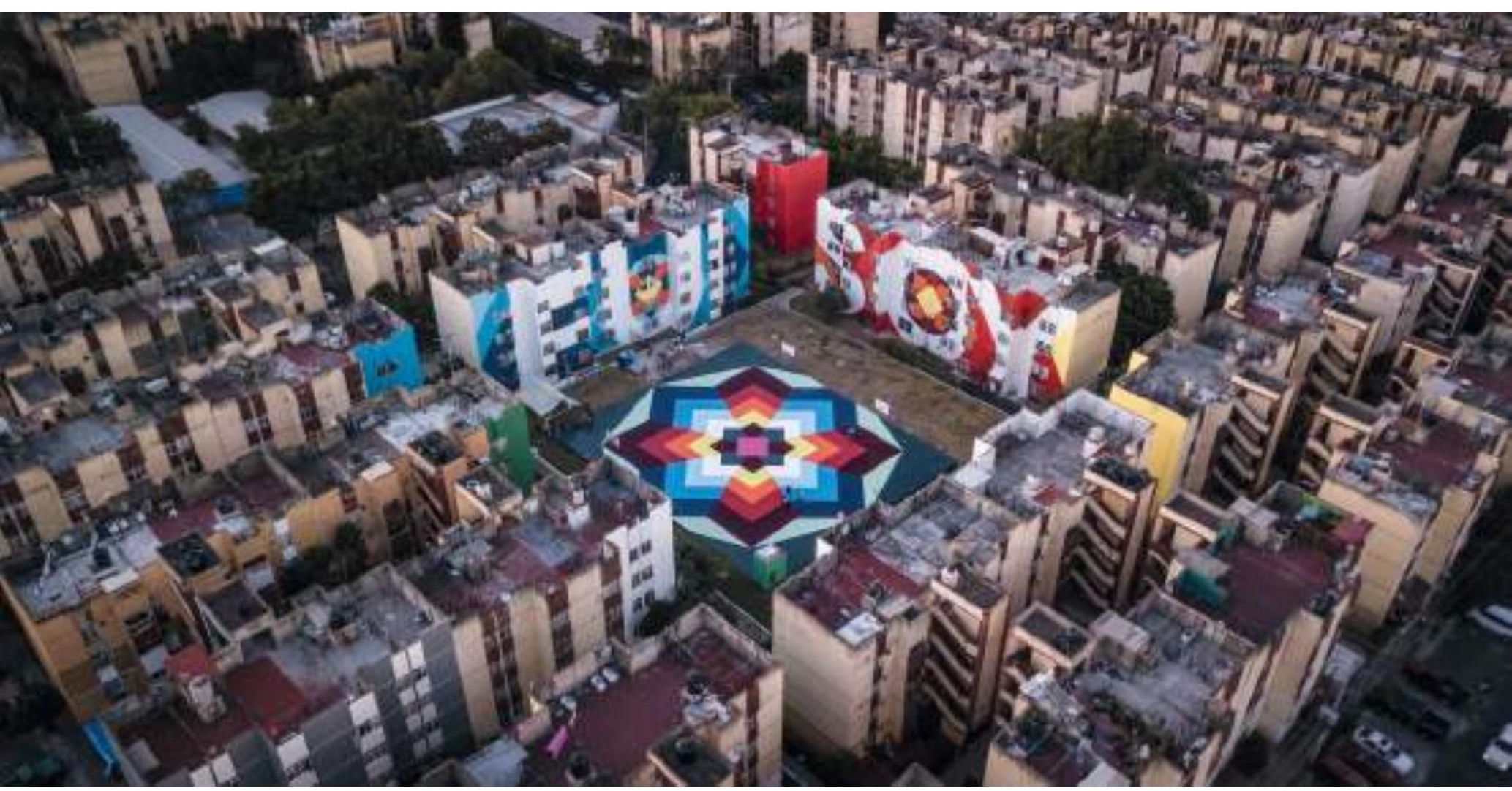

FUI, SOY, SERÉ (I was, I am, I will be) are the words that shout the three facades that surround the plaza, and that represent the strength of the identity of the Mexican people. The richness of his past, the firmness to keep him alive in the present and the knowledge that in the hands of the people of today is keeping his identity beating in the future. One of the main instruments of the niérika, is the Hi'ikuri (Peyote). In the work, two of the main instruments to access the Nierika are also represented: On the two central facades, the Hi'íkuri, as the peyote is called in the Wixárika culture. Its ritual consumption is associated with the ability to see, to understand the world from the divine revelations. It provides a way to understand the world beyond the obvious.

On the floor of the square, the Tsi + kri, a Nierika of utmost importance.

Legend has it wixárika that Kayumarie, one of the gods of creation, looked through the Tsik + ri to see the world in its entirety, and know that it was exactly what he wanted to create. It also serves as a guide and as an element of protection. 


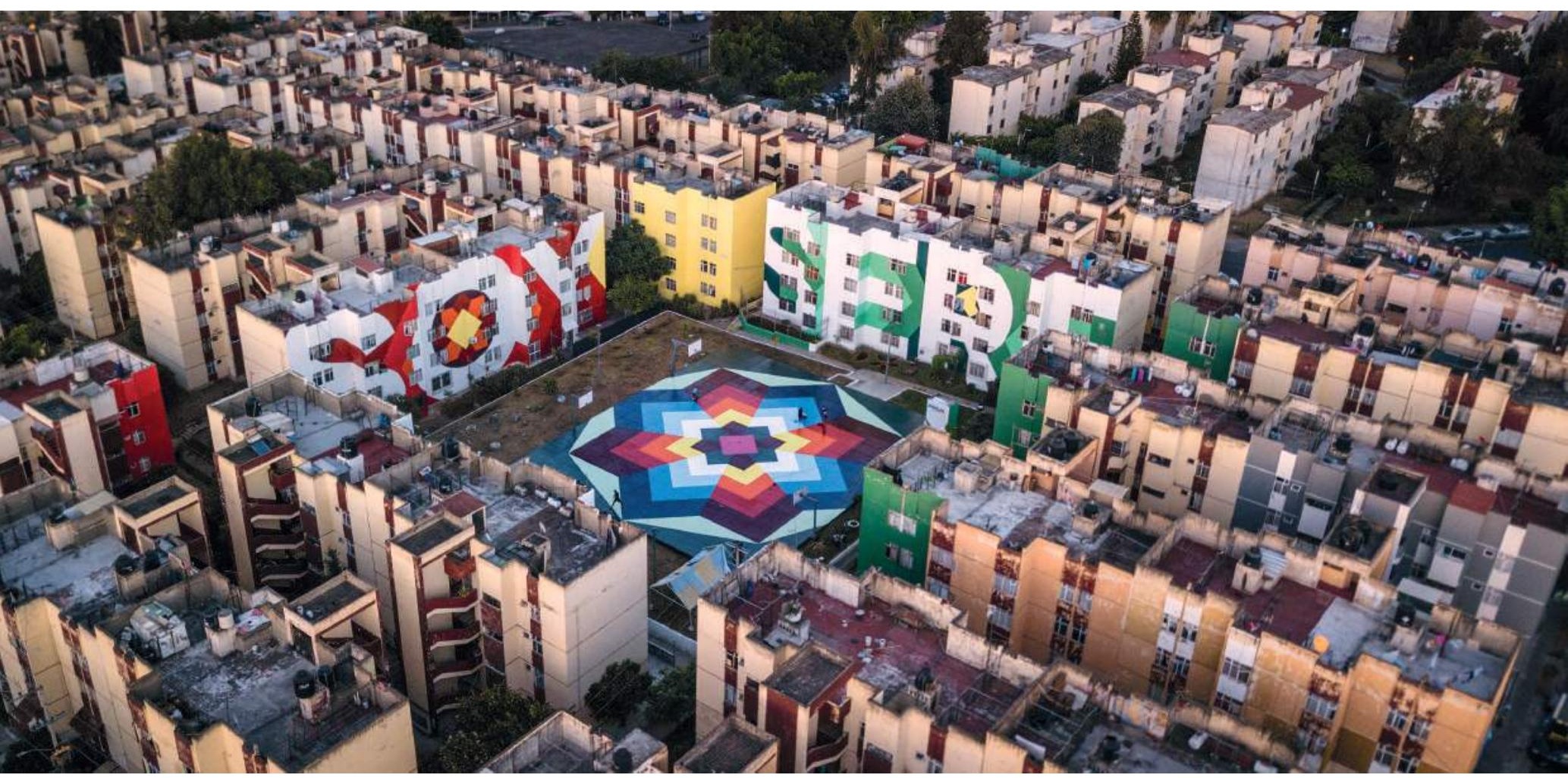

The color in the Wixárika culture is also a guide, and an element of protection. The colors of the work make reference to the fundamental triad of the wixárika conception:

Blue:TUTUTZI MAXA KWAXI (The creador)

Red:TATEWARI (God of fire)

Green:TUKUTZI NAKAWE (Grandmother Earth)

The process has been developed together with the Department of Culture of Guadalajara, that took the challenge of activate the area through "Cultura Itinerante" activities, "Arte sin Paredes" and "Festival Sucede". The goal was to settle a more open social fabric, capable of embrace outside incentives, and prepare the community for the upcoming project.

Our first contact with the neighbors was through one of the surveys that let us to study the context of the area and create two design options. After that, both design options were presented to the neighbors, so that they could vote. They finally chose Nierika. The last stage was the execution, and also was conceived collaboratively. Six unemployed neighbors were instructed to work in heights, and then hired to work with us.

As Nierika, we felt the work and it's development like a transgenerational mirror. A place built on bridges between different social realities working together. This way of building cities should be a model today, in order to develop the society of the future.

\section{Credits}

The work has been possible thanks to the support of the Madrid City Council, Guadalajara City Council, FIL Guadalajara, Pinturas Prisa and, in particular, to the unconditional support of the residents of the Infonavit Independencia Housing Unit and the volunteers of the University of Guadalajara. 


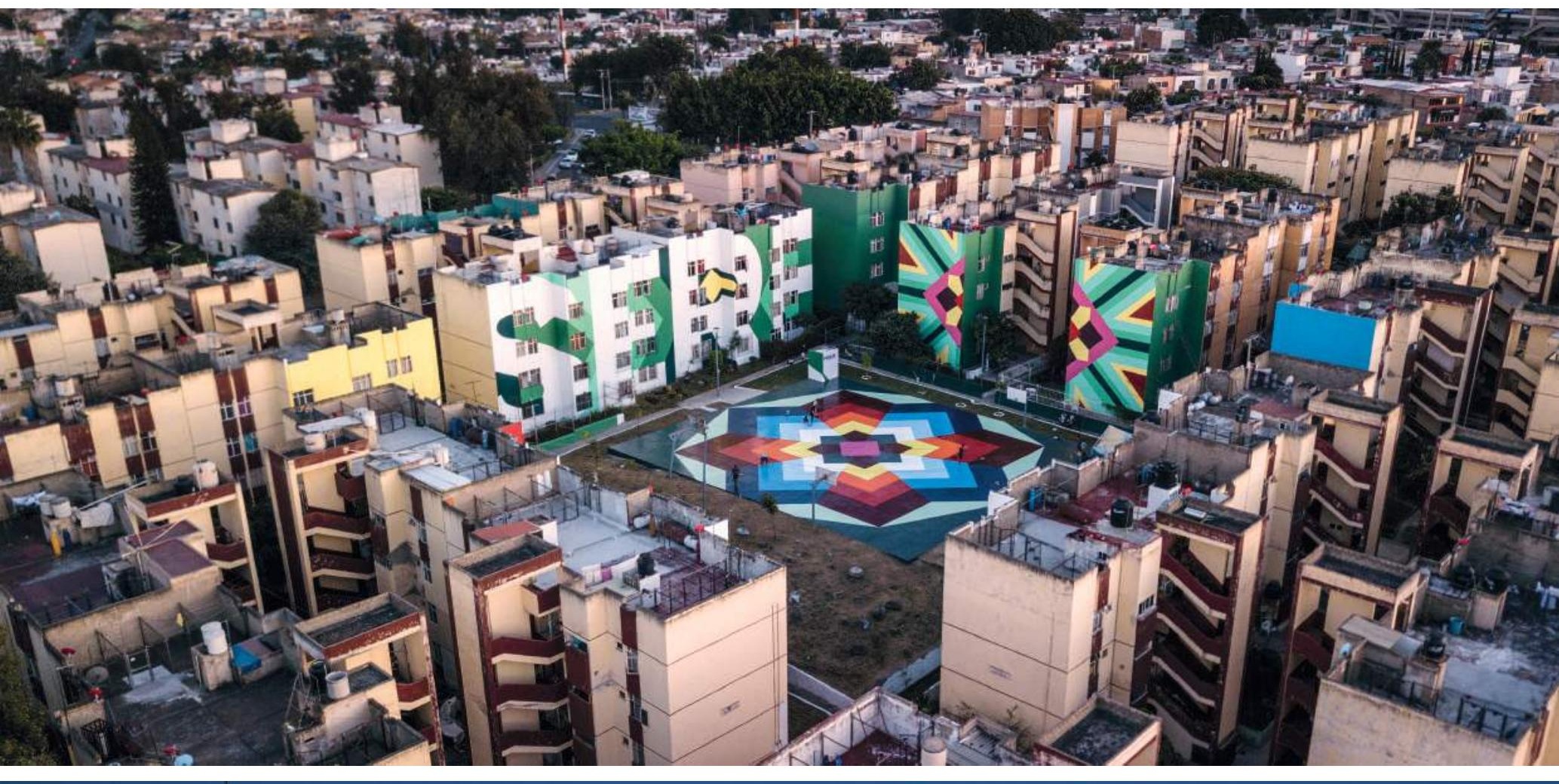



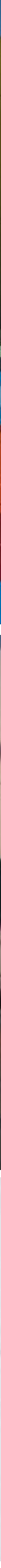

24 | The Journal of Public Space, 3 (2), 2018 | ISSN 2206-9658

City Space Architecture / UN-Habitat 
Javier Serrano Guerra, Juan Jaume Fernández, Pablo Ferreiro Mederos, Pablo Purón Carrillo
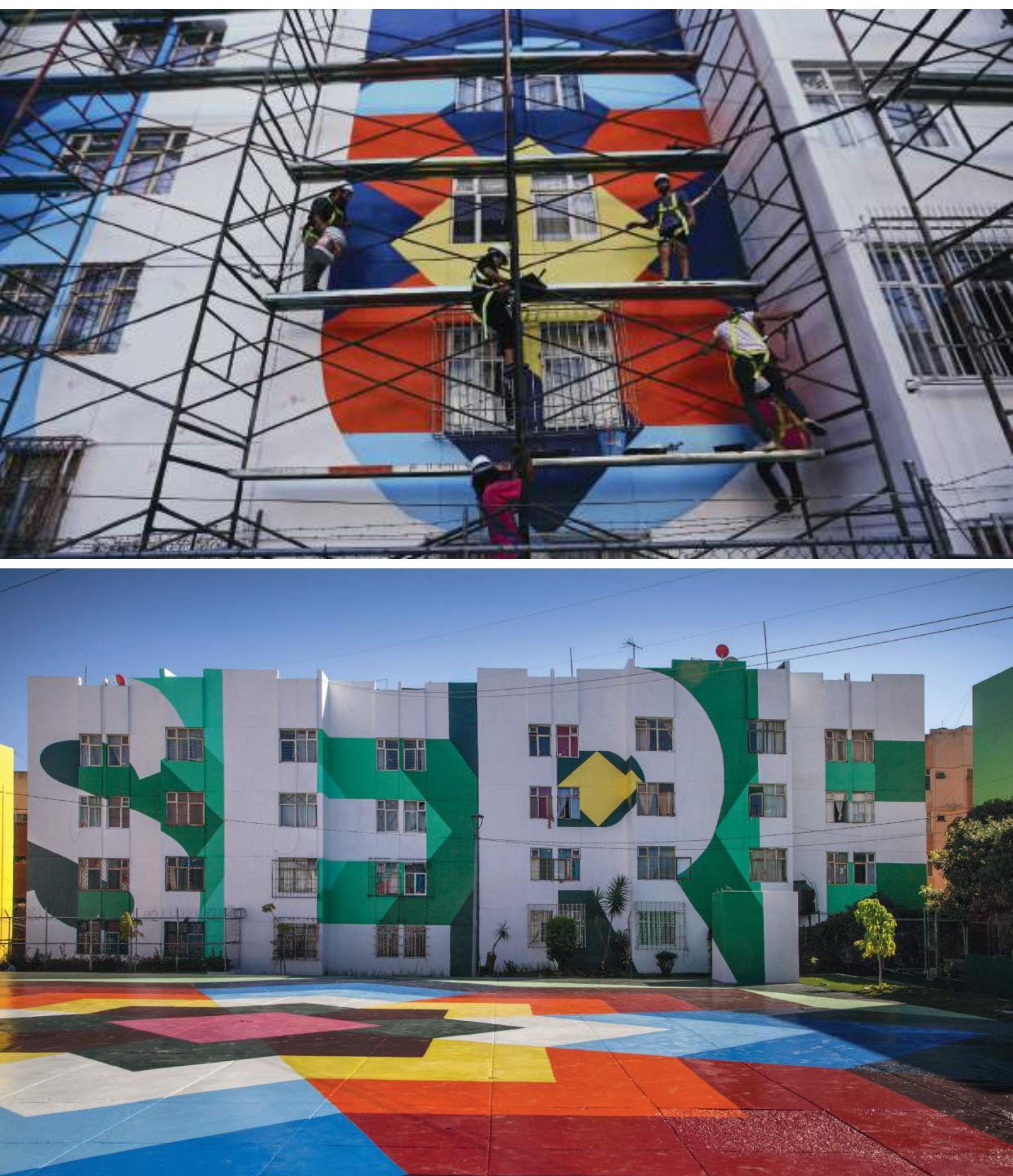

25 | The Journal of Public Space, 3 (2), 2018 | ISSN 2206-9658

City Space Architecture / UN-Habitat 

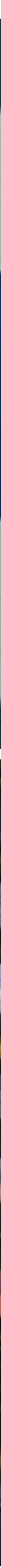

26 | The Journal of Public Space, 3 (2), 2018 | ISSN 2206-9658

City Space Architecture / UN-Habitat 


\section{SISI NI MASHUJAA}

Kibera, Kenya, 2016

http://www.boamistura.com/\#/project/sisi-ni-mashujaa

In January 2016 Boa Mistura travelled to Nairobi, Keniy, developing a project in one of the biggest slums in Africa, Kibera, in which several million people survive each day with less than $I €$ per day.

Kibera means 'woods' and before in the $X X$ century it was a field near Nairobi. The first impact is overwhelming: stench, stagnant water, plastic mountains, animals eating from the trash, houses made up by enticing you can imagine, trenches but most of all mud.

Once you overcome the impact, you discover a totally different universe. A cohesive community, creative and alive. With so much force within it, that looks at life with their eyes quite open, teaching the young that spirit of survival that we haven't seen elsewhere. The best way to describe Kibera is by describing the children's smiles and the way the shout "MZUNGU, MUZUNGU" ("white man", in Swahili) every time they see you.
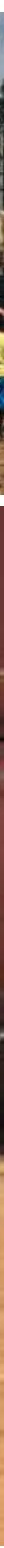

27 | The Journal of Public Space, 3 (2), 2018 | ISSN 2206-9658

City Space Architecture / UN-Habitat 


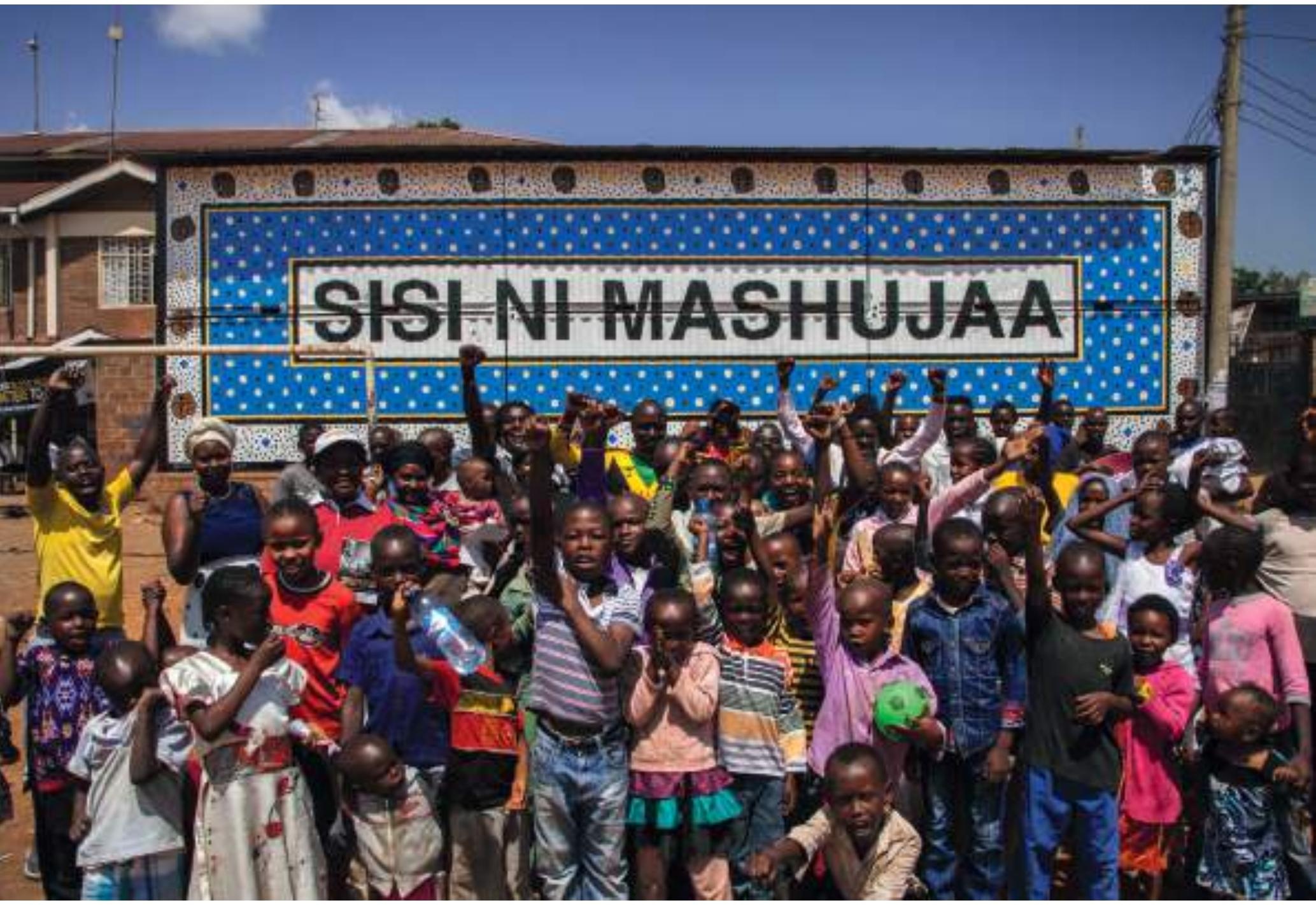

Our project is a reflection of the strength that all the neighbors show every day. It is a tribute to the smile, optimism and determination from every woman and man, to go on with their lives despite the hard conditions.

We have worked over the 6 containers from AMREF hospital at the Laini Saba ground. The only kind of "Open Park" at the township. A space of $2.500 \mathrm{~m} / 2$ in which every day thousands of people walk passing through or to play football or turning into a market or the playground of the three schools that are near it.

It is the greatest witness of the life in Kibera and probably the only public space that could be called square.

The Leso or Khanga is a type of cloth that women use in all of the east of Africa. Within its print, there is always a text that sends a message that accompanies you day by day. Women choose the fabric because of its colors, but especially because of the message. There was not a better tribute to all of Kibera's inhabitants than to dress up AMREF's hospital with this Leso that says:

SISI NI MASHUJAA

which in Swahili means

"We are heroes". 
Javier Serrano Guerra, Juan Jaume Fernández, Pablo Ferreiro Mederos, Pablo Purón Carrillo
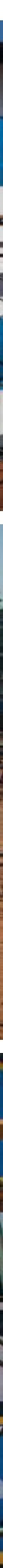

$0 \cdot 0$

. 110.

0.0

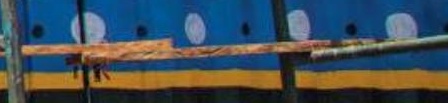



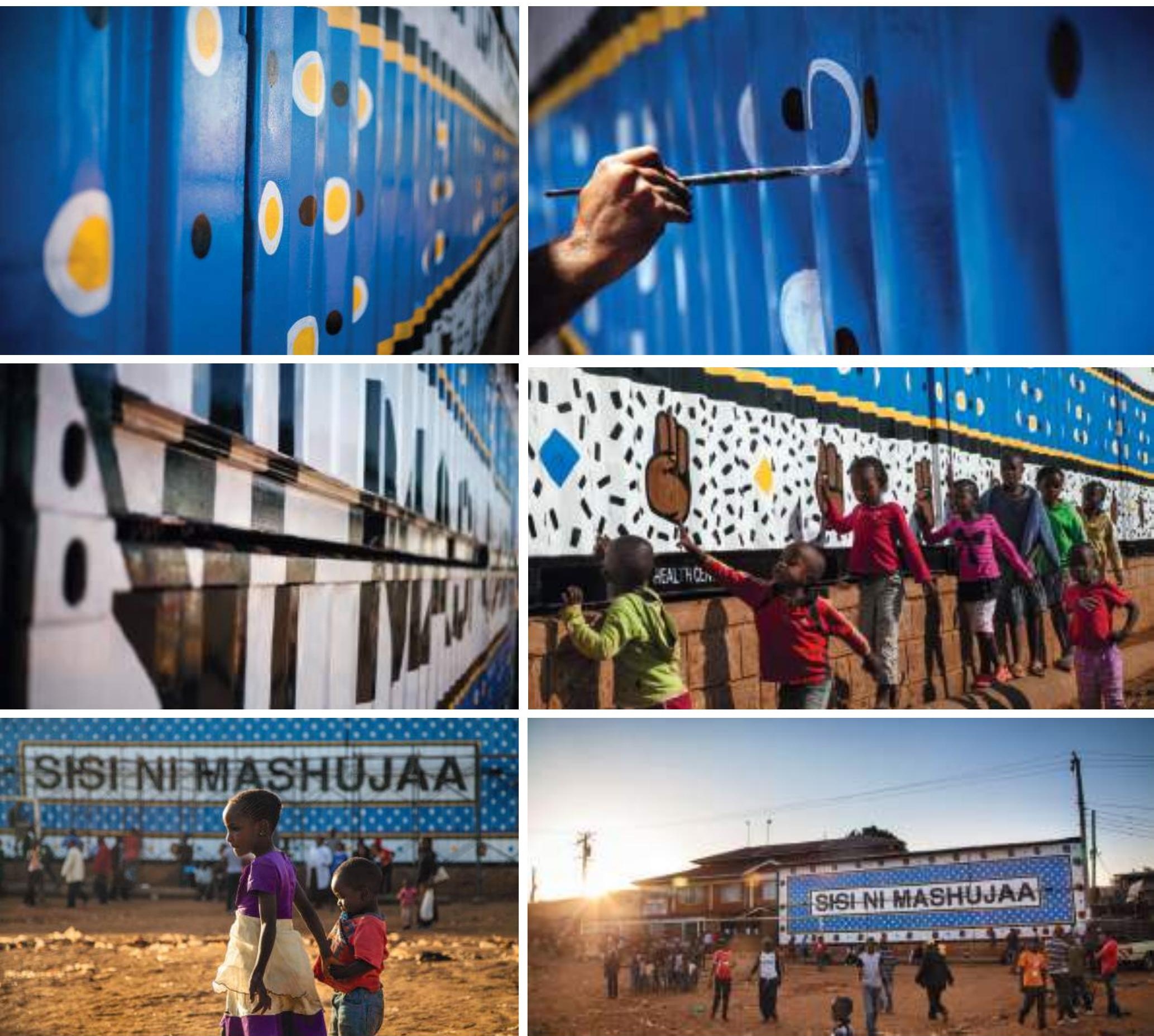

\section{Credits}

I00sqm of mural executed over the containers of the AMREF hospital in the Laini Saba ground at Kibera. The Project has being possible thanks to the healp of "Ghetto Youth Focus Foundation" GYFF, Made in Kibera, Kubura Mas Por Ellos and the support of Renault. Special thanks to Geoffrey, Phlexible, Simon aka Twaani, Coco Tea, Cleophas, Denise, and Warrá for being our guardian angels in the slum. To Andrea, Luis, Carra, Miriam, Raffi, Álvaro and Jose Luis for being our family in Kibera.

Thanks to all the community of Kibera for inspiring us and make us remember the true values in life. 


\section{DREAM HAMAR}

Hamar, Norway. 20I I

http://www.boamistura.com/\#/project/dream-hamar

Hamar is the third largest city in Norway. It is located inland, at the shore of the Mjøsa lake, the soul of the city.

Stortorget is the Norwegian term used to discuss the main space for relationship, a word we understand as public space or square. In this case, the rise of automobile made Stortorget, the city's main parking lot, losing its original use thought as a space for interaction. The architects' firm Ecosistema Urbano proposed a collaborative process to redesign the square.
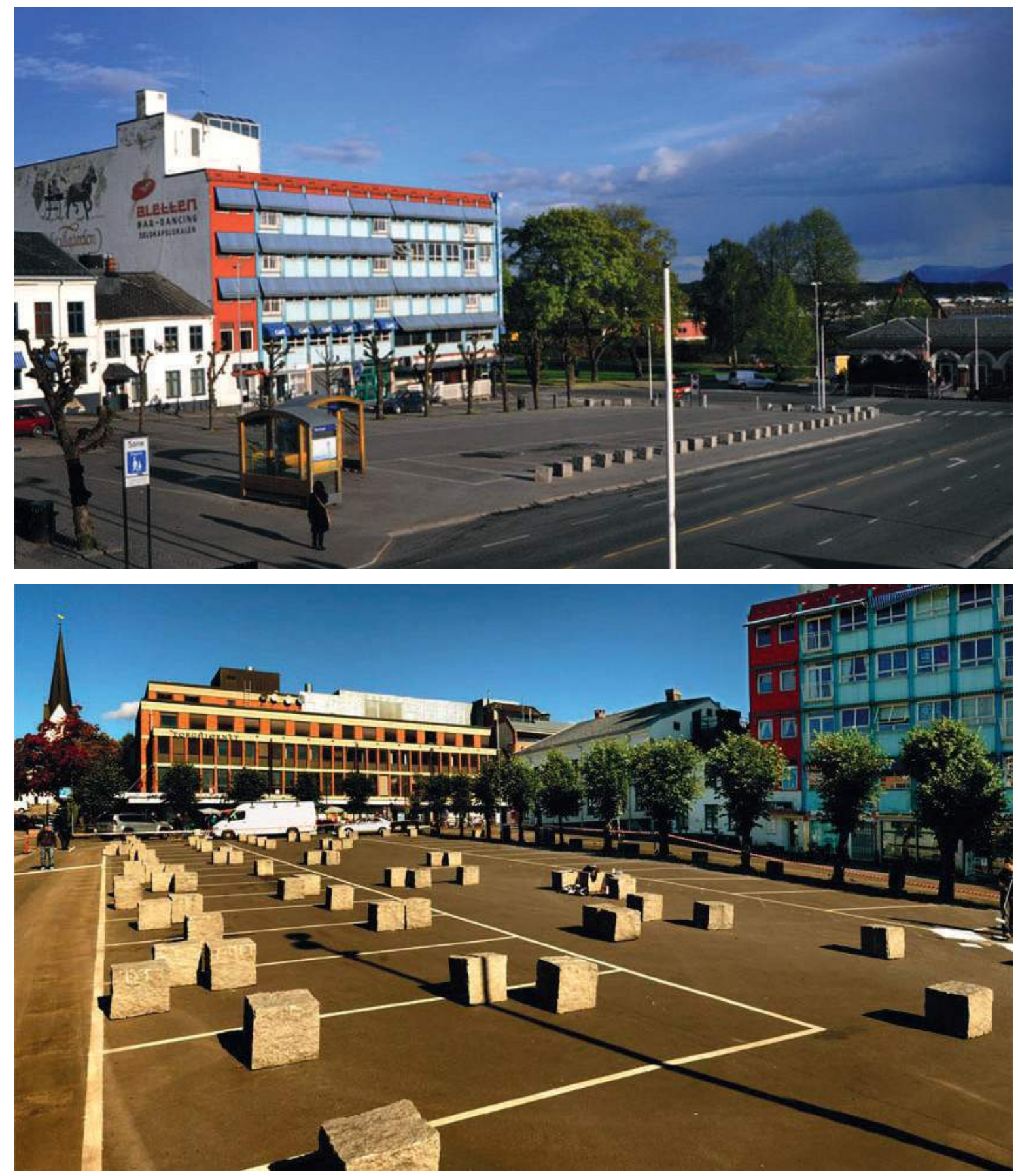

3I The Journal of Public Space, 3 (2), 2018 | ISSN 2206-9658 City Space Architecture / UN-Habitat 


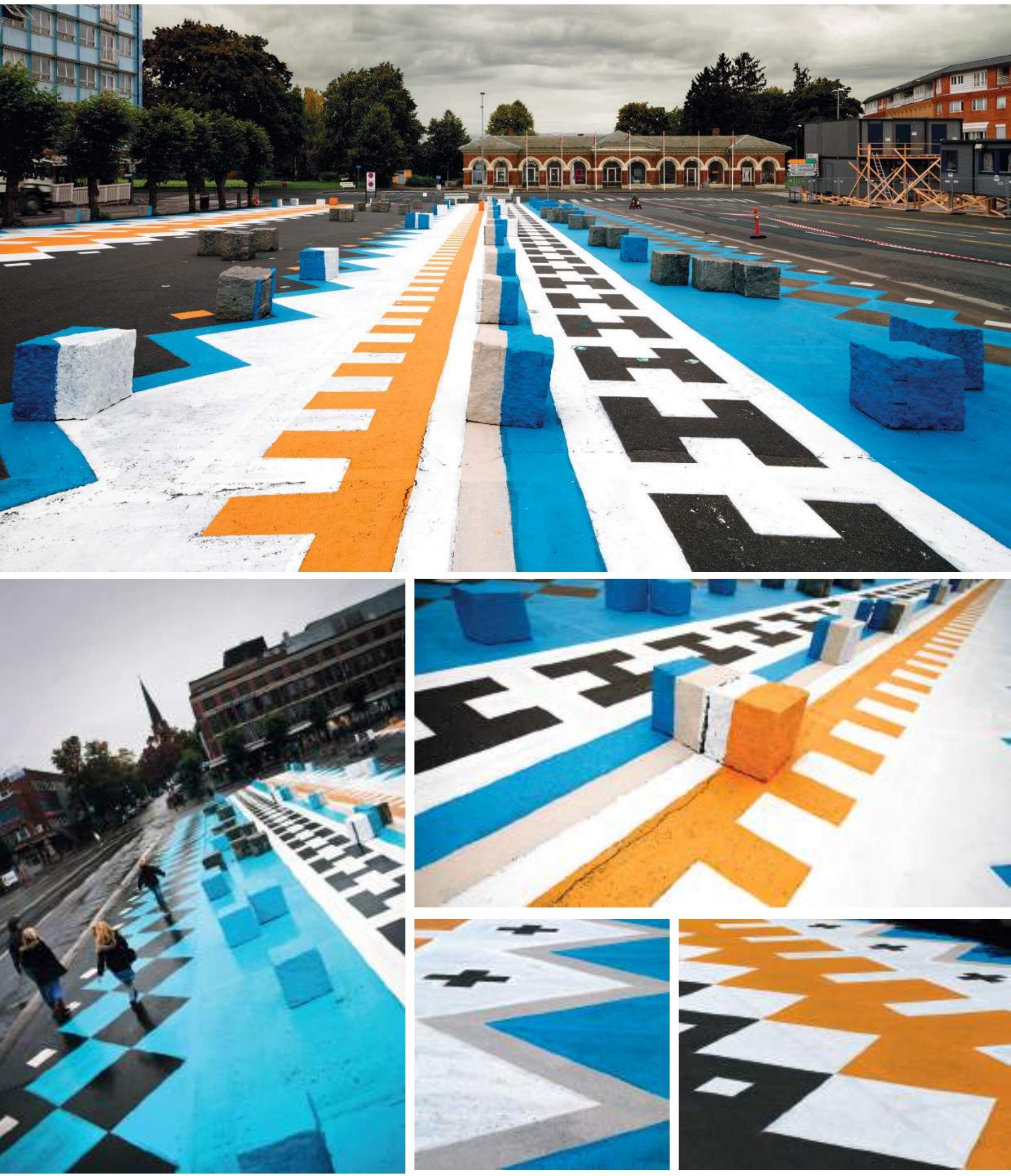

32 | The Journal of Public Space, 3 (2), 2018 | ISSN 2206-9658

City Space Architecture / UN-Habitat 


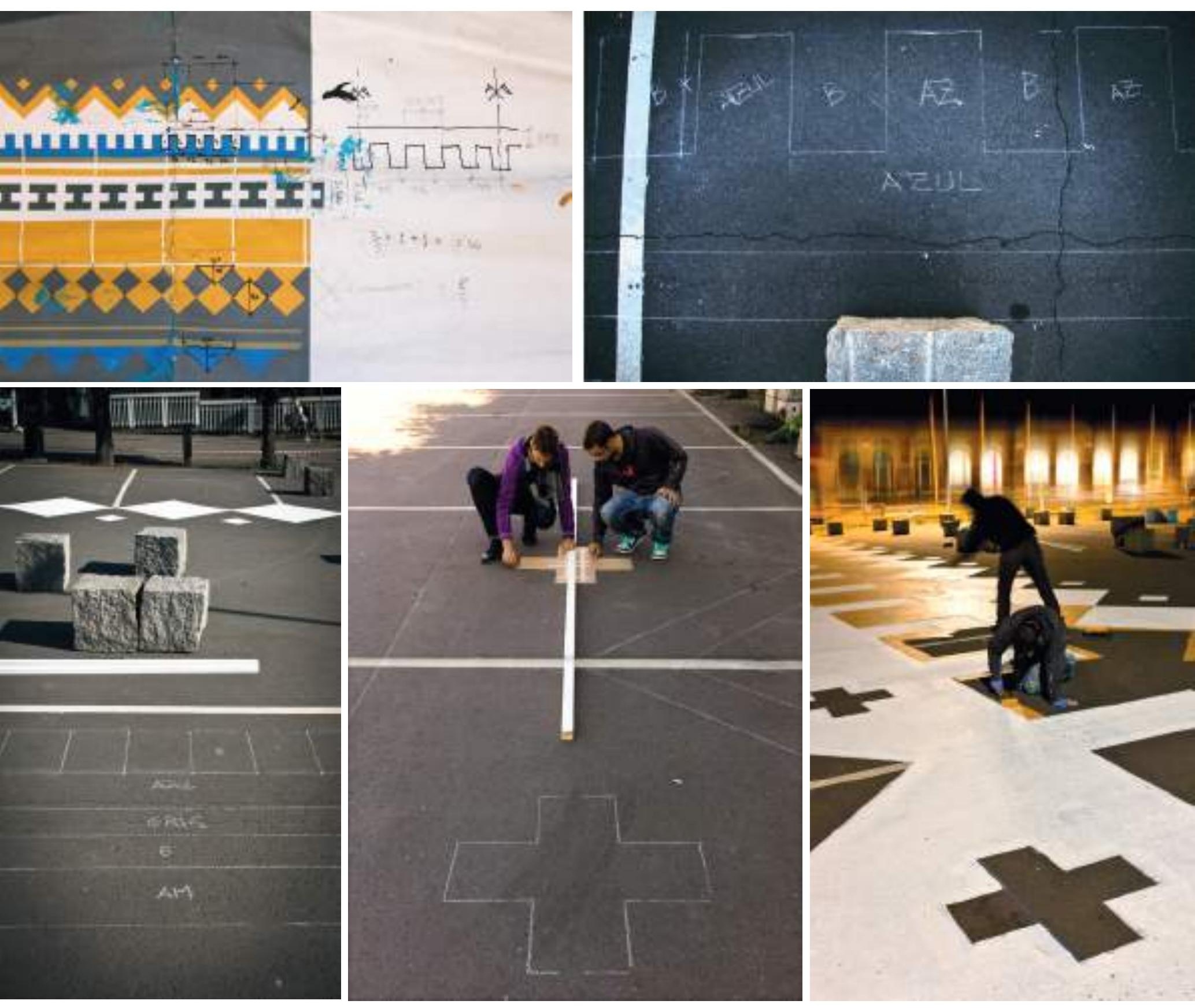

Our intervention consisted on painting the 1500 sqm floor of the square, getting it back for the citizen. We made a contemporary interpretation of the traditional Norwegian patterns, that inspired us to weave a new "blanket". The work area is the city's main square, turned nowadays into a parking lot. The space is surrounded by 37 granite cubes which enclosure the square, only leaving some space for the car access.

Just a few days in the city helped us to appreciate the love that Hamar's inhabitants have for their patterns, which decorate their hats, globes, socks and sweaters.

These clothes are everywhere and are a sign of identity. We studied the origins and the most important designers that have worked with these patterns, so we could remake them and create a new and colored geometry composition.

The first decision was to scatter the bollards, making the area not usable for the cars and setting the space ready for its new use. Then the paint arrived. 


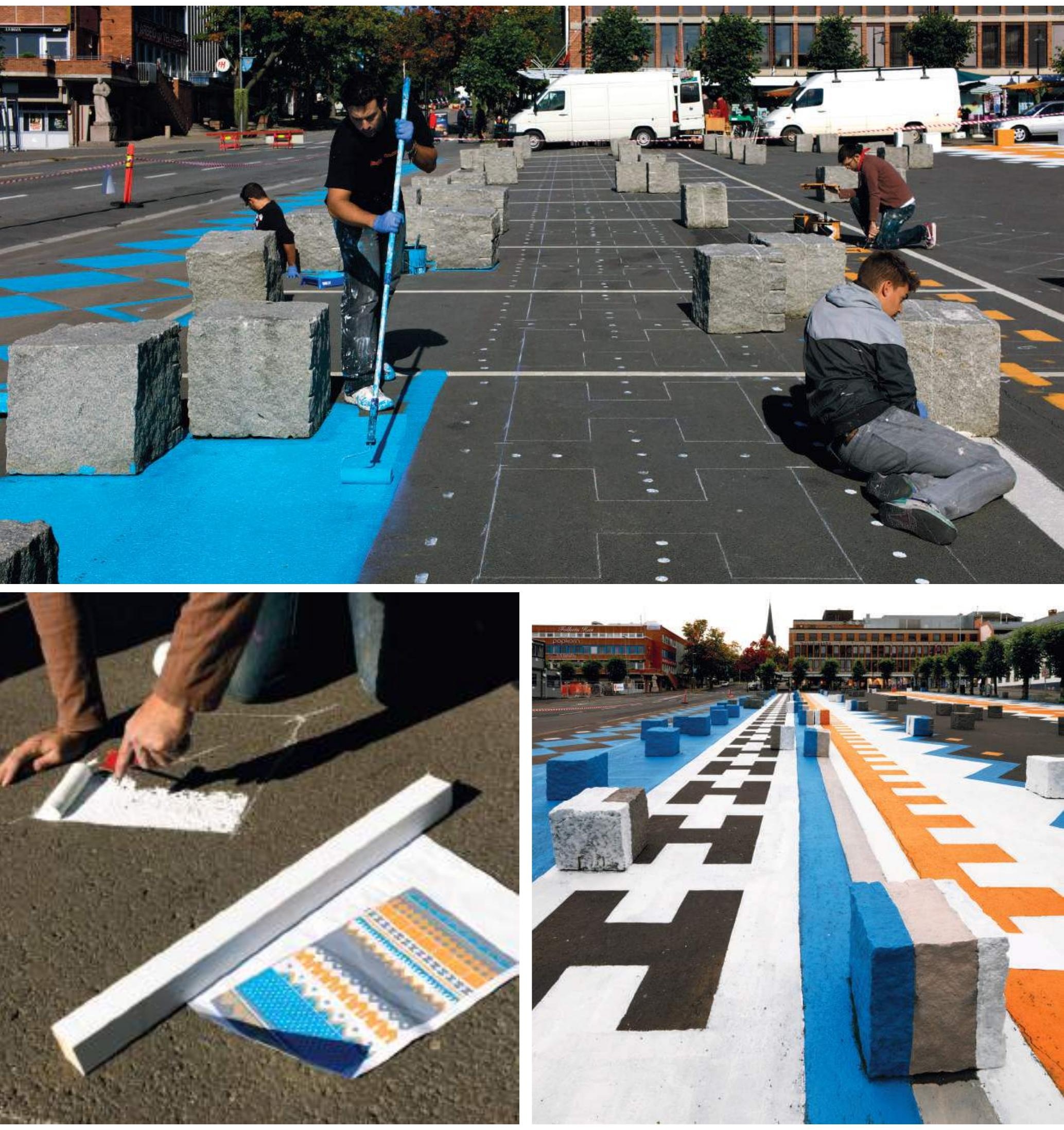

\section{Credits}

Thanks to José Luis Vallejo y Belinda Tato for trusting in us. And all the Ecosistema Urbano team for the support.

34 | The Journal of Public Space, 3 (2), 2018 | ISSN 2206-9658

City Space Architecture / UN-Habitat 


\section{GEOLOGICAL SKIN}

Antofagasta, Chile, 2016

http://www.boamistura.com/\#/project/piel-geologica

Antofagasta is located at the north of Chile, in the second region, being the doors of the Atacama desert. It is a very particular city, developed lengthways following a North-South direction. Is spreads among the narrow space of only $2.5 \mathrm{~km}$ between the first Andes and the Pacific Ocean. It was built based on the mining, that make use of the extremely rich composition of the upland soil.

The neighborhood of René Schneider at the East side of the city, making direct contact with the hills of the early Andes, arises from an informal appropriation of the territory, in what the Chilean call "tomas". A group of new neighbors join together to adapt a terrain and install their new homes. Firstly with tents, then substituted with wooden pieces, metallic sheets and prefab concrete blocks.

The intervention is focused on Serrano with Alfonso Meléndez street, both inside René Schneider neighborhood, at the city of Antofagasta, Chile. Almost 40 houses and 4.000 square meters that completely modifies the appearance of this community, making it visible from the center of the city.

It is framed in the plan of strategic actions from the institution CREO Antofagasta, which aims to reinforce the connectivity between different urban cores of the city. The project takes on the challenge of working hand to hand with a selected group of local artists and neighbors, with the intention of leaving a seed that might grow in the future.

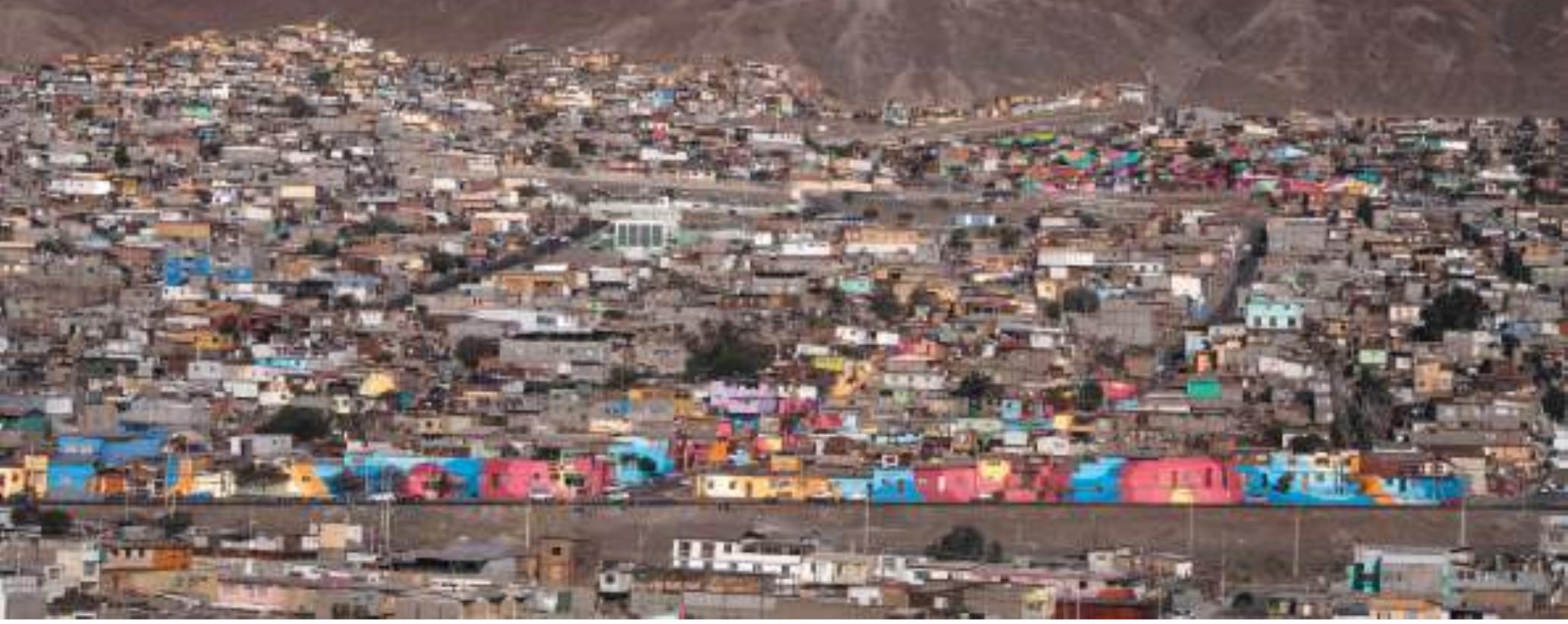

35 | The Journal of Public Space, 3 (2), 2018 | ISSN 2206-9658

City Space Architecture / UN-Habitat 
(ivit.

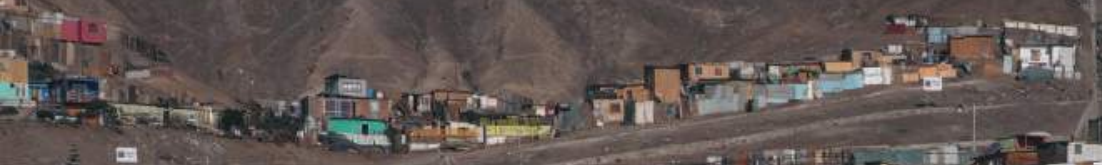

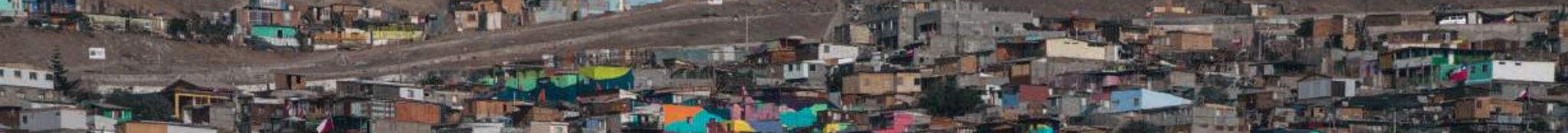

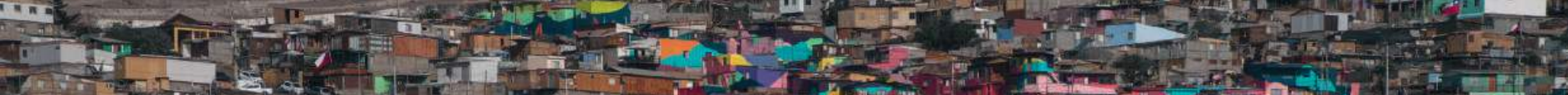

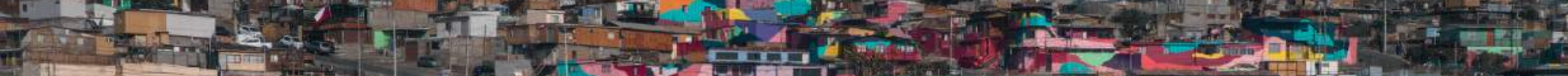

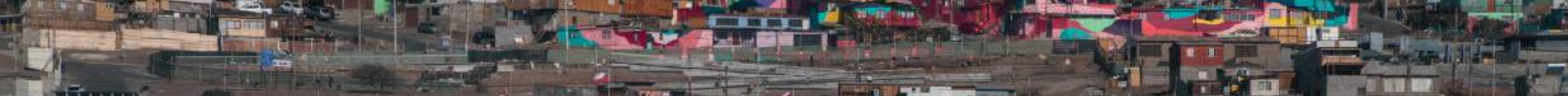

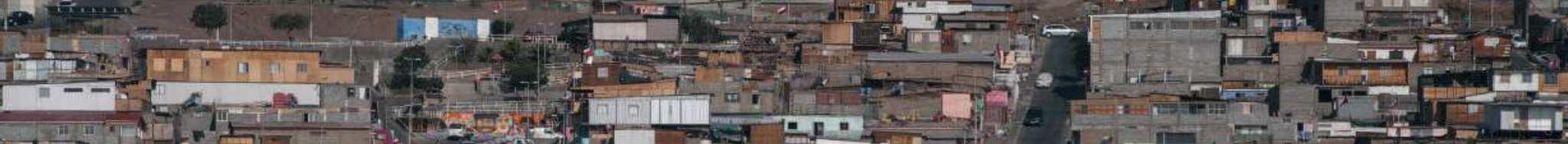
ind

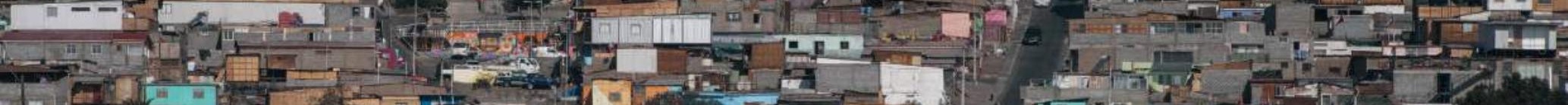

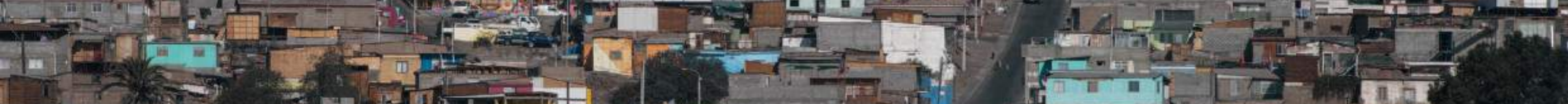

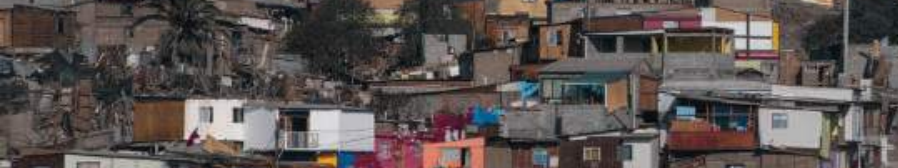

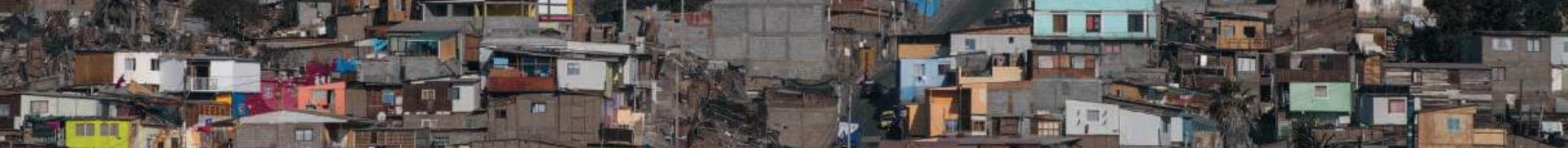

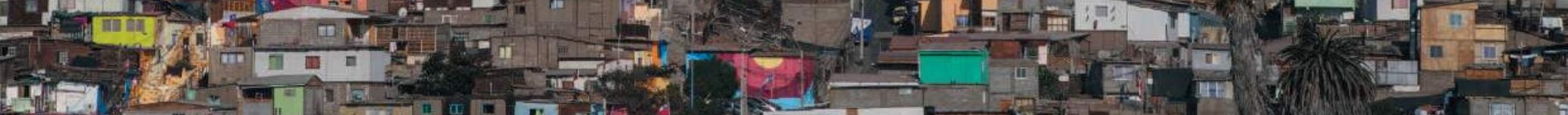

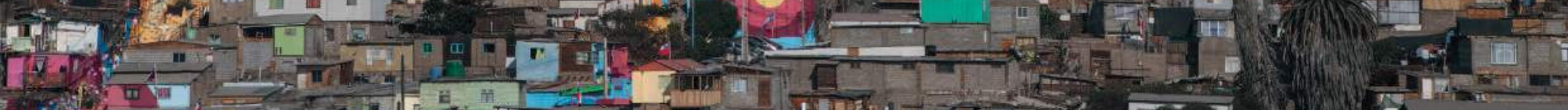

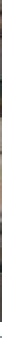

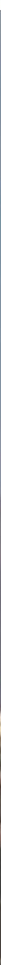

36 | The Journal of Public Space, 3 (2), 2018 | ISSN 2206-9658

City Space Architecture / UN-Habitat 


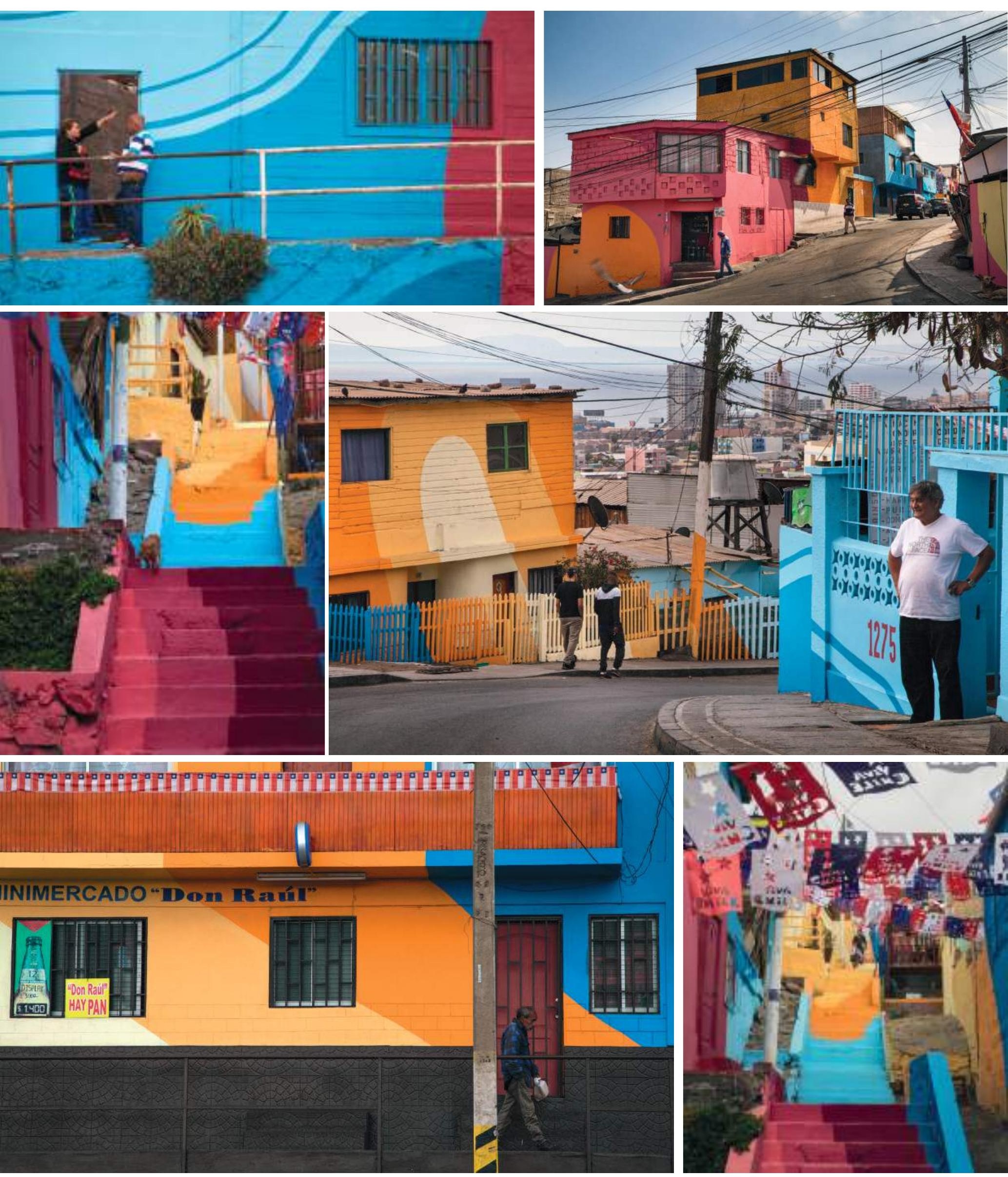

37 | The Journal of Public Space, 3 (2), 2018 | ISSN 2206-9658

City Space Architecture / UN-Habitat 

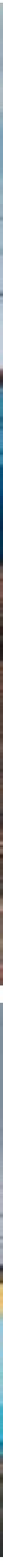

René Schneider South community, stands out for the strength of its neighbor association. Tamara and Yaque are the leaders of a neighbor group who have built up great efforts in their community. Before starting the project we held several encounters with them in their community headquarters. There we could get the bases for our concept design. Some of the drawings they did were specially inspiring.

The mineral richness of the second region soil is the key factor for the city's development, and it is essential for its future growth. This is what makes Antofagasta a unique city. We confirmed it through the neighbor queries, in which most of them mentioned mining as the main reason why all the families moved to the city.

The soil of Antofagasta poses an extremely rich color palette. We studied it in order to create our own chromatic range, interpreting the geologic section to adapt it to the urban landscape.

38 | The Journal of Public Space, 3 (2), 2018 | ISSN 2206-9658

City Space Architecture / UN-Habitat 
Javier Serrano Guerra, Juan Jaume Fernández, Pablo Ferreiro Mederos, Pablo Purón Carrillo
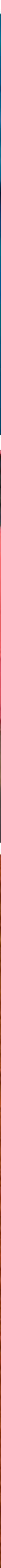

39 | The Journal of Public Space, 3 (2), 2018 | ISSN 2206-9658 

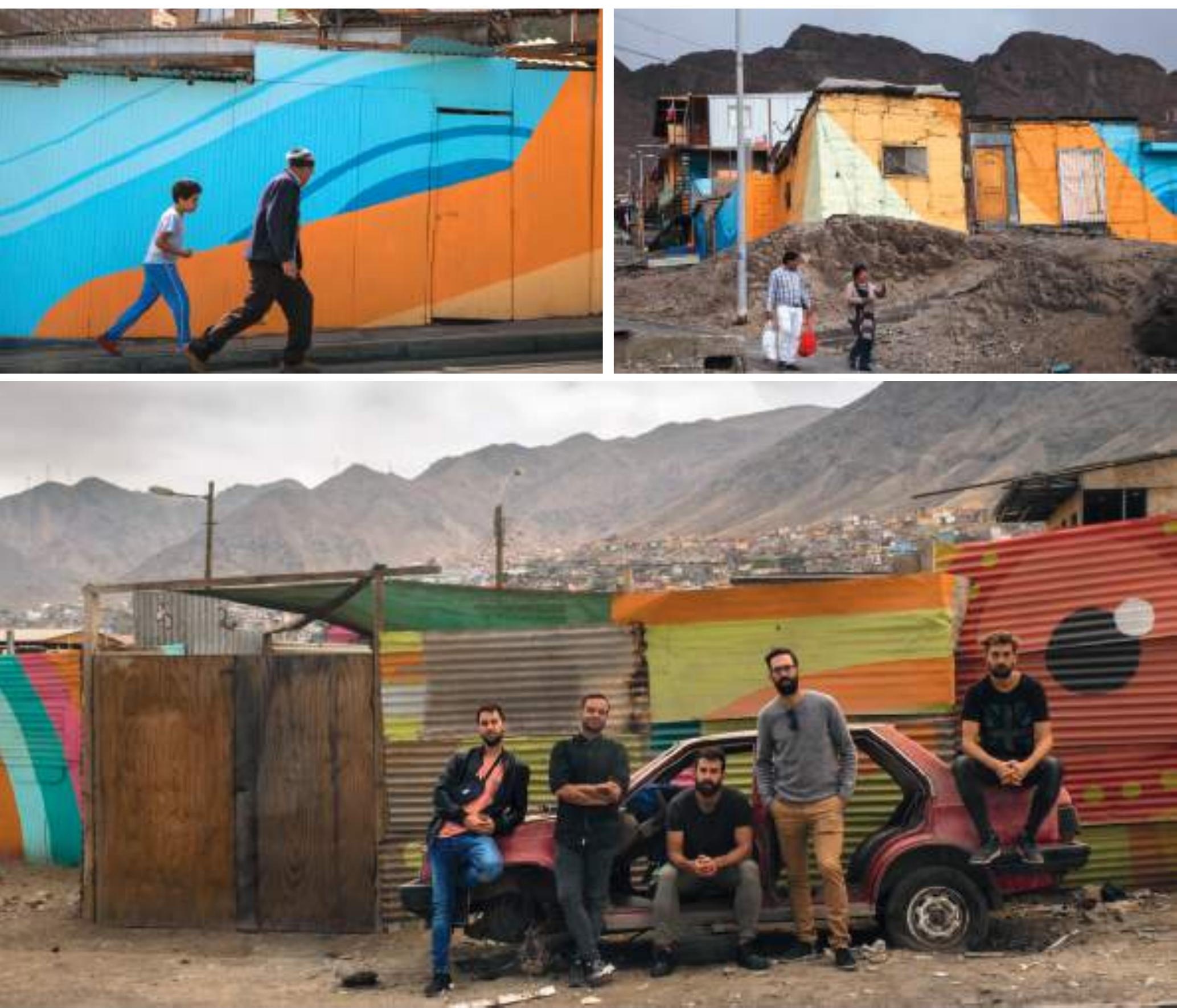

\section{Credits}

Nearly 4.000 sqm painted at the René Schneider South community.

It has been directed and financed by the development plan from the CREO Antofagasta institution. With the collaboration of Marchantes and Balmaceda Arte Joven as work field supporters and with the neighbor association from René Schneider Sur neighborhood. We want to thank Pablo López and Pancho Cooper for being the best orchestra directors we've ever had; Katy Tapia, Diana and Jean Carla for their labor and for joining together everybody at the workfield.

It's been a pleasure to work and learn from local artists Zopa, Seba Ovnie, Marte, Paulo Araya, Katica, Koté, Basco, Cristian, Gabriel, Javiera Aròstica, Jano and Juan Miranda. And to share great moments with Francesca Barrales, miss Marcia, Peka, Yesenia, Chili, Susana, Sr Pedro, Sr Osvaldo, Sr Hugo and the rest of René neighbors.

40 | The Journal of Public Space, 3 (2), 2018 | ISSN 2206-9658

City Space Architecture / UN-Habitat 
The Journal of Public Space

ISSN 2206-9658

2018 | Vol. 3 n. 2

https://www.journalpublicspace.org

\title{
Soft, Sexy, Fantastic. Inflating public space Daniel Felgendreher \\ hello@danielfelgendreher.eu
}

\begin{abstract}
Plastique Fantastique has been operating as a platform for temporary architecture at the interface between art, architecture and urban practice since its founding 1999 in Berlin. Influenced by the unique cultural and spatial conditions that made Berlin a laboratory for testing new ways of acting in public space at the time, the studio has specialised in creating immersive, pneumatic installations made of plastic film as mutant, low energy architectures for ephemeral activities. With their temporary urban interventions they intend to involve citizens in creative processes provoking them to activate, and enjoy public space.
\end{abstract}

Keywords: temporary architecture, pneumatic sculpture, ephemeral installation, art in public space, local participation

To cite this article:

Felgendreher, D. (2018). Soft, Sexy, Fantastic. Inflating public space. The Journal of Public Space, 3(2), 4I-74, DOI I0.3289|/jps.v3i2.II09

This article has been accepted for publication in The Journal of Public Space. Please see the Editorial Policies under the 'About' section of the journal website for further information. 


\section{Friction}

Squeezing between buildings, squashing under bridges, entwining around lampposts or trees: a key quality of their work are the various modalities of physical contact the spatial installations get into with the existing built environment. The pneumatic structures of Plastique Fantastique sometimes enter into a gentle, sometimes into a more provocative dialogue with their context. During the Helsinki Design Week 2016 for instance they wrapped a space around the Three Smiths Statue on the eponymous square in the Finnish capital. People came for concerts, talks or just to meet each other at the foot of the statue. The friction that the elastic, airy volumes produce with the rigid, static built structures of the city is not only of a physical kind - the plastic rubs against the brick wall of a building - but also of a programmatic one: the interventions disrupt the everyday use (or non-use) of certain public spaces in a way that they provoke a new reading of, and a new reaction to them. The former produces a straightforward image of the latter, which allows for an immediate visual communication of the interests and modi operandi of their work. As well as of their approach to public space.

The inhabitants of Copenhagen could witness this double friction in Summer 2013 when the studio developed a one hundred square meter single-layer pneumatic structure that was installed in thirteen different public spaces of the city as part of Metropolis - Festival and Laboratory for Art and Performance in Urban Space. Traveling around from location to location the inflatable space was squeezed under trees close to a lake in Vanløse, between climbing walls on a playground in Nørrebro or around the iconic objects on Superkilen park. It constantly adapted its shape in relation to specific elements of the sites. At the same time the intervention introduced certain bewildering activities that momentarily changed the character of the public spaces chosen. People were invited to a silent disco at one of the noisiest intersections in the city, to do astronomy on a playground, dance to hip hop in front of a supermarket or do martial arts on a popular square.

\section{Playfulness}

Plastique Fantastique uses temporary architectures as tools to investigate urban and social issues in a playful manner. On the one hand, playing can serve here as metaphor for the studio's strategy to intervene in public space: an iterative design approach that embraces chance, accidents and a multitude of participants. Plastique Fantastique plays with the neighbourhood, the existing buildings, trees or bridges. An oversized walk-in plant pot is placed around a tree in a Berlin street and turned into a vibrating pneumatic sound system together with sculptor Markus Wüste and composer Lorenzo Brusci (Karl Marx Bonsai, 48h Neukölln Festival, Berlin, 2008).

On the other hand, playing is meant quite literal. It is the most universal mode of interaction with their installations. They invite people to play with them - and with one another. Inflatables are fantastic, seductive and sexy - for people of all ages. The tactile and aesthetic qualities of the inflatables provoke quite immediate and sensual reactions, regardless of people's education, age or cultural background. The pneumatic structures are reminiscent of places, objects or architectures most people have vivid and positive memories of: fun fairs, balloons or bouncy castles. They do even hold erotic qualities. People react intuitively to them, be they in more figurative shapes, like a giant ring on the former city hall of Logroño (RINGdeLUXE la Rioja, at Concéntrico Festival, Logroño, Spain, 2018) or a walk-in strawberry ice-cream cone (Strawberry Ice Cream Cone - 
100\% Morango at 180 Creative Camp, Abrantes, Portugal, 2015), or in more abstract ones.

Play has a distinctive force to excite and to enthuse us. The act of playing unleashes an excessive joy that the toy-like interventions of Plastique Fantastique try to amplify. Why? They want people to have fun in public space and convince them that it is fun to become active in public space. Proposing objects or environments that people can project desires onto and that trigger their imagination, is an invitation to engage in exploration and creative processes.

\section{Synesthesia}

Similar to some radical 1960's architects collectives, such as Haus-Rucker-Co, Plastique Fantastique is interested in challenging habitual perceptual patterns. We hear shadows (Loud Shadows | Liquid Events at Oerol Festival, Terschelling, The Netherlands, 2017) or colours (Sound of Light at Urban Lights Ruhr, Hamm, Germany, 20I4). The rhetorical synesthesia in the title of their work "Loud Shadows | Liquid Events" refers to this quality of multisensorial experiences the installations of Plastique Fantastique hold. The project was developed for the 2017 edition of Oerol Festival, an annual performing arts and music festival held on the Dutch island of Terschelling. In collaboration with the dance company LeineRoebana from Amsterdam, the composer Kate Moore and The Stolz Quartet, the studio created an immersive performance in the Formerum forest on the island.

The interplay of material, movement and sound results in acoustic and visual distortions a spatial experience in which different areas of perception are coupled.

The project is a collaborative piece realised by artists coming from different backgrounds: dance, music, architecture. Plastique Fantastique is, rather than a collective, a platform for temporary architecture on which different creative subjects like architects, sculptors, musicians, designers can contribute their expertise in various constellations. This form of cross-disciplinary collaboration is rooted in the very beginnings of the studio. Until now various projects were realised in cooperation with the artists Markus Wüste, Marco Barotti and many others.

\section{Berlin}

The work of Plastique Fantastique is in many ways inspired by the ideas and attitudes of the radical artists and architects collectives of the 1960s and 1970s. But what has shaped the practice of the studio the most, were the experiences that its founder made exploring the various subcultures in the 1990s in Berlin. Marco Canevacci moved to the city in 199I, shortly after the Berlin Wall came down. The vacuum which was left by the disappearance of the East German State offered a special political situation characterised by a status of anarchy which allowed the appropriation of large empty parts of the inner city. The activists of the club and art scene continuously appropriated public space for temporary uses. Berlin was full of spaces that existed for a limited lapse of time. Plastique Fantastique is a product of the unique conditions of the time: the political establishment had quite a reactionary vision for the unified city. The way it was implemented in architecture and urbanism produced many banal results. At the same time there were plentiful subversive counter-strategies to do or think the development of Berlin. Indeed 
Marco, who studied architecture at the Technical University of Berlin, could not imagine to work as conventional architects in this climate.

After having been "culture consumers" for several years, in 1999 Marco and some of his friends - Pietro Balp, Raffaele Distefano, Michael Heim, Pato Troncoso - became themselves an active part of the underground culture of the city. They rented a 2000 square meters former factory directly at the riverside in Berlin Friedrichshain and turned it into a club called „Deli an der Schillingbrücke“ offering a mix of different activities: techno, installations, concerts, video screenings, games and alike. The group realised quickly that the hall was too big to heat in winter and began to develop strategies to structure it spatially in order to gain warm spaces. Construction foil was the cheapest material they could find to produce their first lounge inflated with hot air. So they started working with pneumatic structures which led to the founding of Plastique Fantastique. At the moment the permanent members of Plastique Fantastique are Marco Canevacci, Yena Young and Daniel Felgendreher.

\section{Softness}

From a purely pragmatic point of view, the spatial installations of Plastique Fantastique are particularly suitable for temporary events such as festivals, performances or concerts. Made of polyurethane, polyethylene, latex and textile, the volumes are easy to produce, to build up or dismantle within minutes. They can be used to temporarily induce strong atmospheres. However, beyond relying on the obvious advantages of plastic being cheap, flexible and easy to assemble, Plastique Fantastique is interested in a consequent, conceptual use of the eponymous material. By working with pneumatic structures made out of plastic the studio advocates a specific attitude towards the production of urban spaces, some sort of - to make an analogy to the material properties - softer approach. Working with inflatables defies stability or geometric perfection, which can be seen as quite problematic or even frustrating from the perspective of the architect. The behaviour of inflatable structures is often unpredictable. They can neither be fully controlled, nor permanently grounded. They are in constant movement. Wind can be monitored and an air pressure can be regulated. Yet, they seem to behave in a way that asserts a certain agency to them. Working with inflatables therefore bears risks and denies their designers full artistic agency. In the work of Plastique Fantastique this is a quality rather than a disadvantage. Working with structures that are flexible - soft enough to be debatable, changed, or appropriated resonates with an interest in cooperative and community-based design processes or bottom-up planning strategies. The studio regularly initiates workshops with students or members of local communities to share know-how, ideas and opinions or discover pressing issues they experience in their neighbourhood or city.

The pneumatic installations of Plastique Fantastique can be monumental and fragile at the same time. With their softness they subvert conceptions of stability and permanence in architecture. Rather than working with conventional elements of the architect's or the urban planner's tool box, such as monumental, static, everlasting structures, inflexible and expensive materials or masterplans and rigid planning procedures respectively, the studio envisions a temporary urbanism with ephemeral experiments, removable and mobile interventions, inviting the public to participate in the process. 


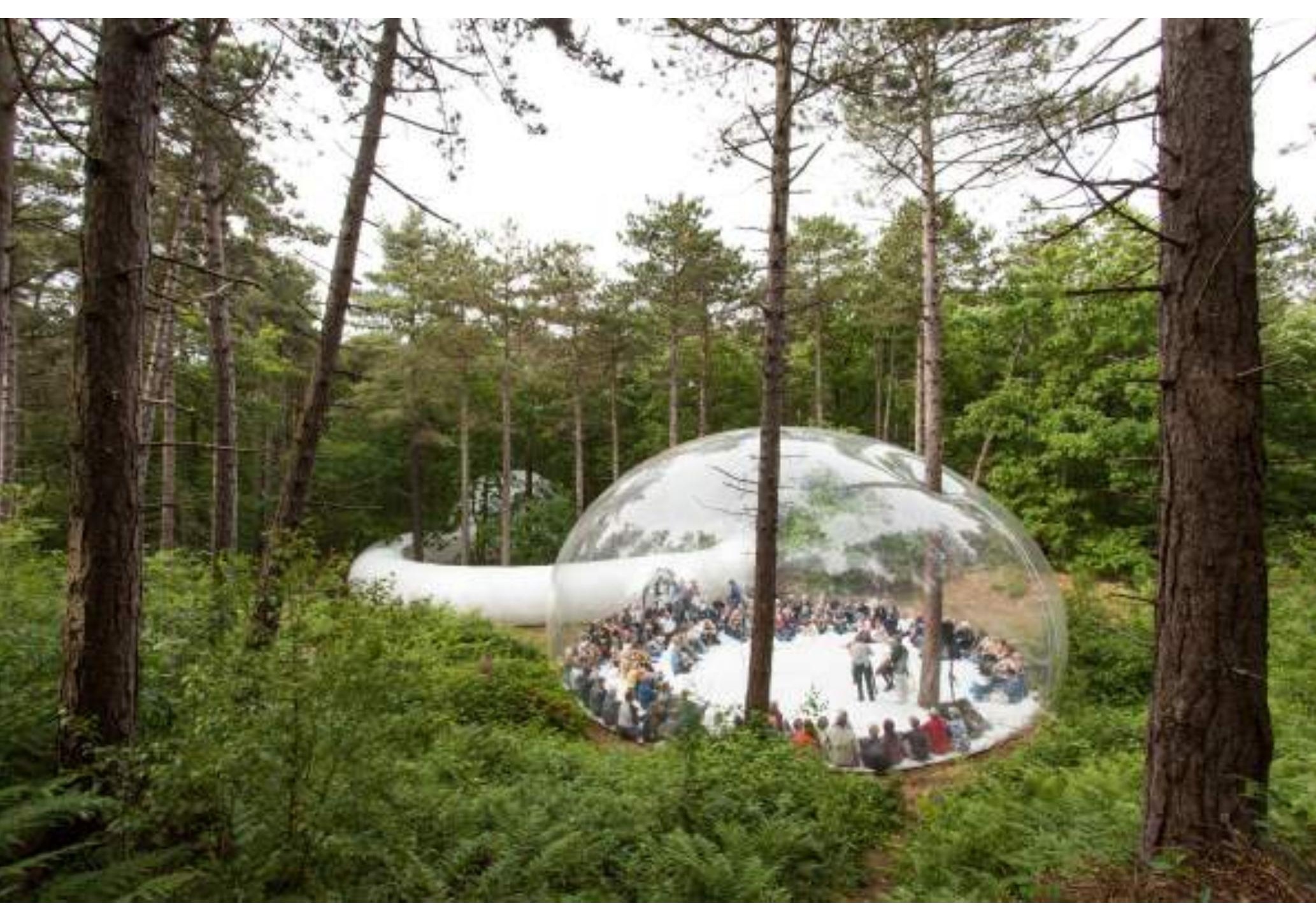

Plastique Fantastique is a platform for temporary architecture which samples the performative possibilities of urban environments. Established in Berlin in 1999, Plastique Fantastique has been influenced by the unique circumstances that made the city a laboratory for temporary spaces and has specialised in creating pneumatic installations as alternative, adaptable, low energy spaces for temporary and ephemeral activities.

The transparent, lightweight and mobile shell structures relate to the notion of activating, creating, sharing and transforming public space and involving citizens in creative processes. They are in many ways the simplest of structures - a skin that separates but also connects. Pneumatic architecture is at the same time subversive and adaptable, welcoming fleeting activities and free experiments, breathing new life into the city and making the invisible visible. At present Plastique Fantastique develops project-oriented teams to realise a wide range of projects worldwide, depending on the specific request. A number of these site specific installations are realised in cooperation with other visual artists, sound and light designers, performing artists, composers and political groups.

www.plastique-fantastique.de 
Soft, Sexy, Fantastic. Inflating public space

Marco Canevacci born 1970 in Rome, Italy.

Marco Canevacci is a Berlin-based artist. He moved to Berlin in 199I and studied Architecture at Technical University Berlin. Since 1999 he has built large scale installations in different urban environments under the name of Plastique Fantastique.

Yena Young born 1982 in Seoul, Korea.

Yena Young is a Berlin-based artist. She studied architecture at the Yonsei University in Seoul and moved to Helsinki in 2008 to study Spatial Design at Aalto University. She joined Plastique Fantastique in 2012.

Daniel Felgendreher born 1987 in Dresden, Germany.

Daniel Felgendreher is a Berlin-based designer, writer and editor. He started studying architecture at the Technical University Berlin and graduated 2014 from the Bartlett School of Architecture (UCL) in London. He has researched and written about architecture, pop culture and urban development for online and print publications. In 2018 he joined Plastique Fantastique as a designer.

46 | The Journal of Public Space, 3(2), 2018 | ISSN 2206-9658

City Space Architecture / UN-Habitat 


\section{AEROPOLIS}

\section{https://plastique-fantastique.de/AEROPOLIS}

The concept of AEROPOLIS has been conceived following the invitation of Københavns Internationale Teater to join the Metropolis Festival 2013.

The architecture of the 100 sqm single-layer pneumatic structure has been designed with 2 optional ,tops“ to allow maximal mobility and flexibility during its tour through I 3 different locations in Copenhagen. Furthermore the installation always changes its shape into endless constellations by squeezing through the existing urban or natural environment - thus enhancing the perception of those peculiar public spaces by focussing them.

AEROPOLIS offers a communication platform to experience a sequence of I 3 urban activities with changing scenographies all curated together with local cultural institutions: astronomy between two climbing walls in Nørrebro, kindergarten and hip hop in front of a supermarket in Valby, meditation and yoga by a lake in Vanløse, performances at Islands Brygge, martial arts at Superkilen, lectures in Amager, silent disco at one of the noisiest intersections in the city in Nordvest etc. The AEROPOLIS community centre breathes new life into the city and makes the invisible visible.

AEROPOLIS is a Plastique Fantastique project in cooperation with Københavns Internationale Teater on the occasion of the Metropolis Festival 2013.

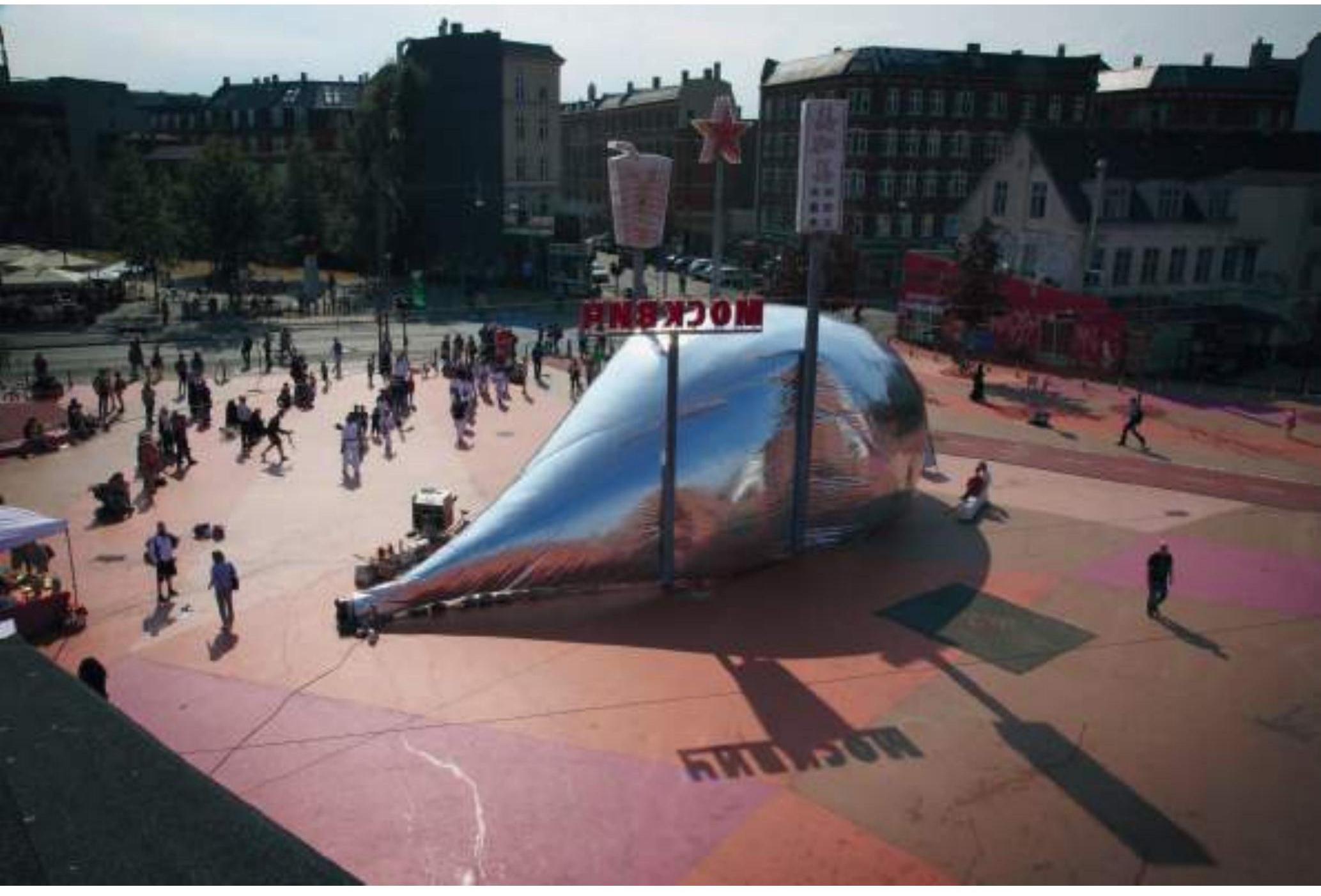



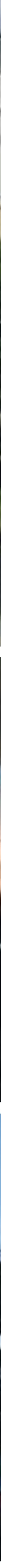

48 | The Journal of Public Space, 3 (2), 2018 | ISSN 2206-9658

City Space Architecture / UN-Habitat 
$3 x^{3}$

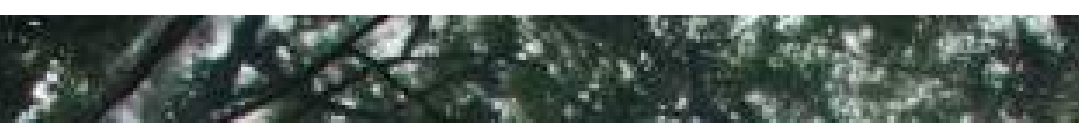

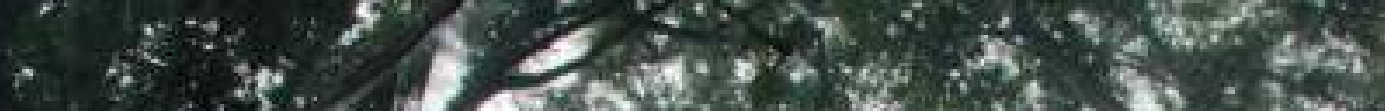

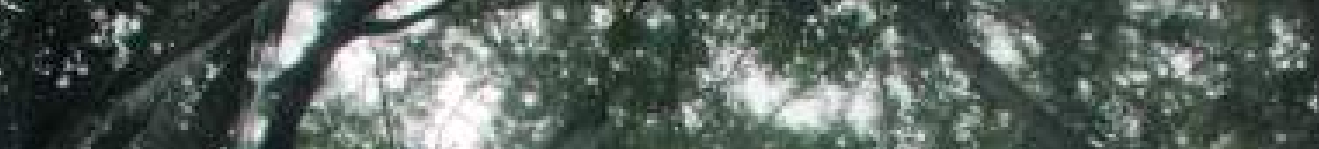

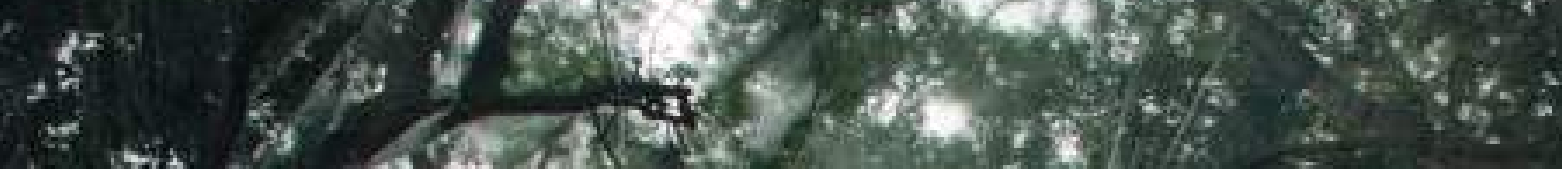

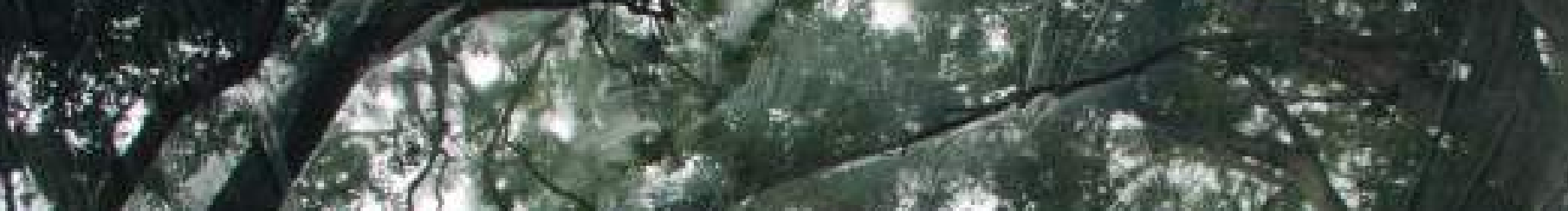

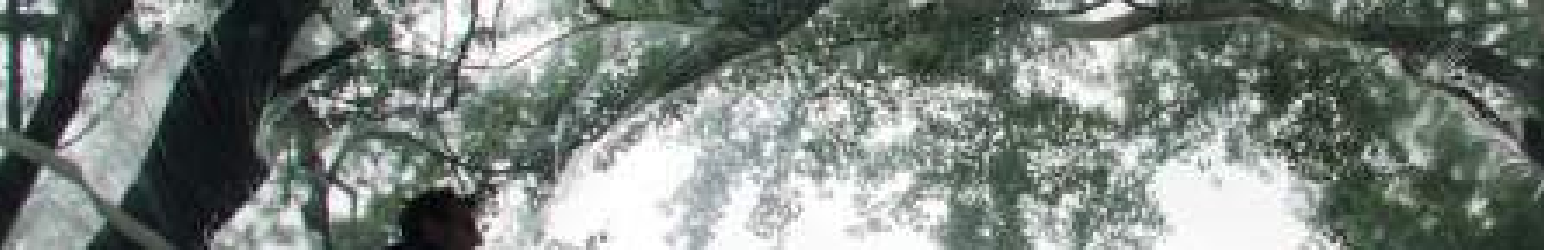
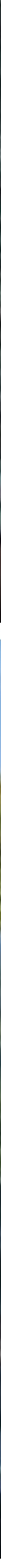

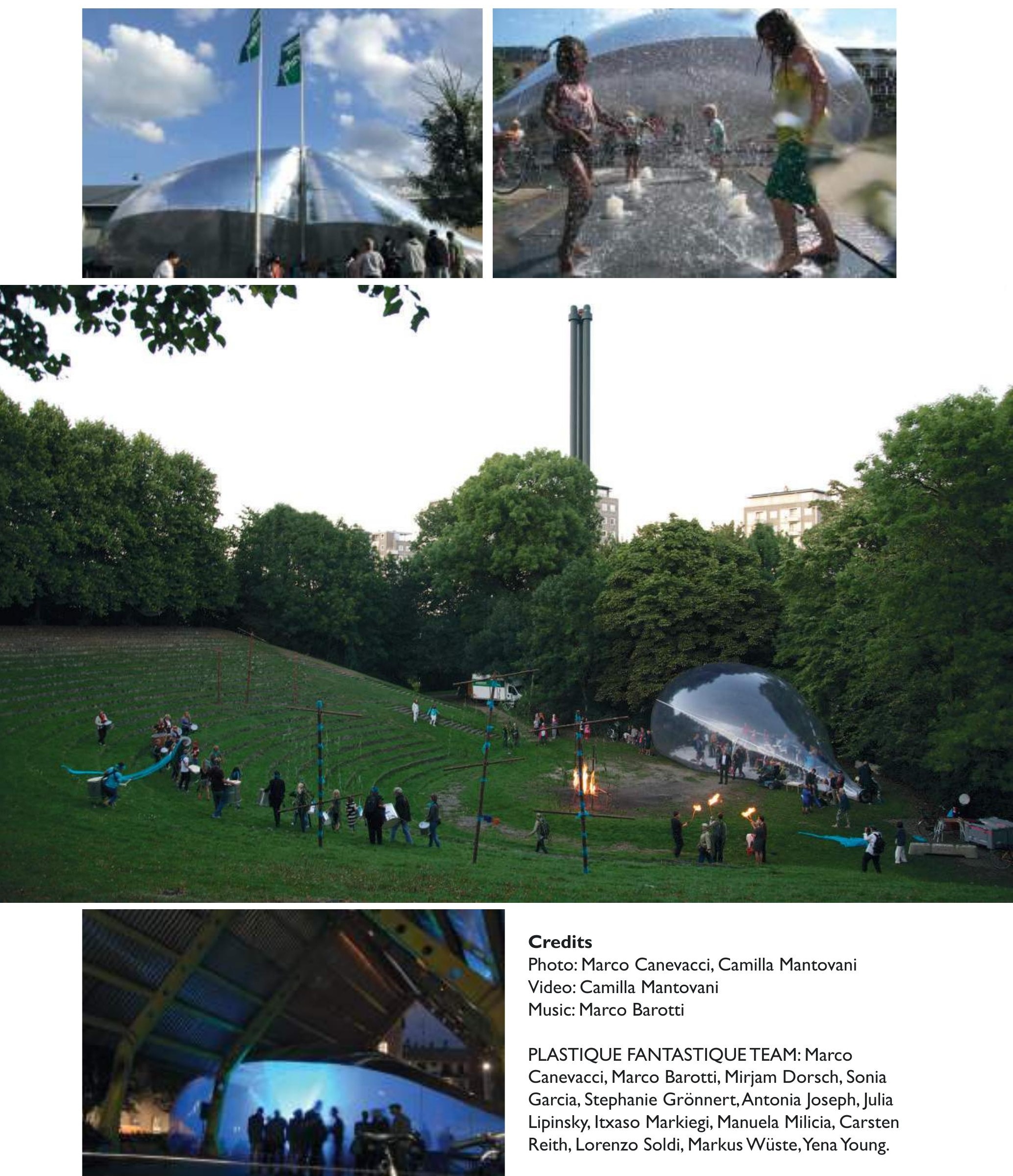

\section{Credits}

Photo: Marco Canevacci, Camilla Mantovani

Video: Camilla Mantovani

Music: Marco Barotti

\section{PLASTIQUE FANTASTIQUE TEAM: Marco}

Canevacci, Marco Barotti, Mirjam Dorsch, Sonia

Garcia, Stephanie Grönnert, Antonia Joseph, Julia

Lipinsky, Itxaso Markiegi, Manuela Milicia, Carsten

Reith, Lorenzo Soldi, Markus Wüste, Yena Young.

50 | The Journal of Public Space, 3 (2), 2018 | ISSN 2206-9658

City Space Architecture / UN-Habitat 


\section{KARL MARX BONSAI}

48 Stunden Neukölln, Karl Marx Allee, Berlin 2008

\section{https://plastique-fantastique.de/KARL-MARX-BONSAI}

I trunk, I garbage can and 3 benches are temporarily merged into one walkable inflated structure:The Flowerpot. The newly generated pot-space is experienced, animated and amplified by sound - the Flower-Catalyzer. Lorenzo Brusci's compositions and the live acts of Marco Barotti give birth to a vibrating pneumatic sound system.
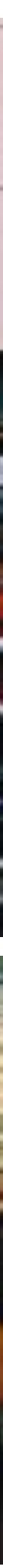

5I | The Journal of Public Space, 3 (2), 2018 | ISSN 2206-9658

City Space Architecture / UN-Habitat 


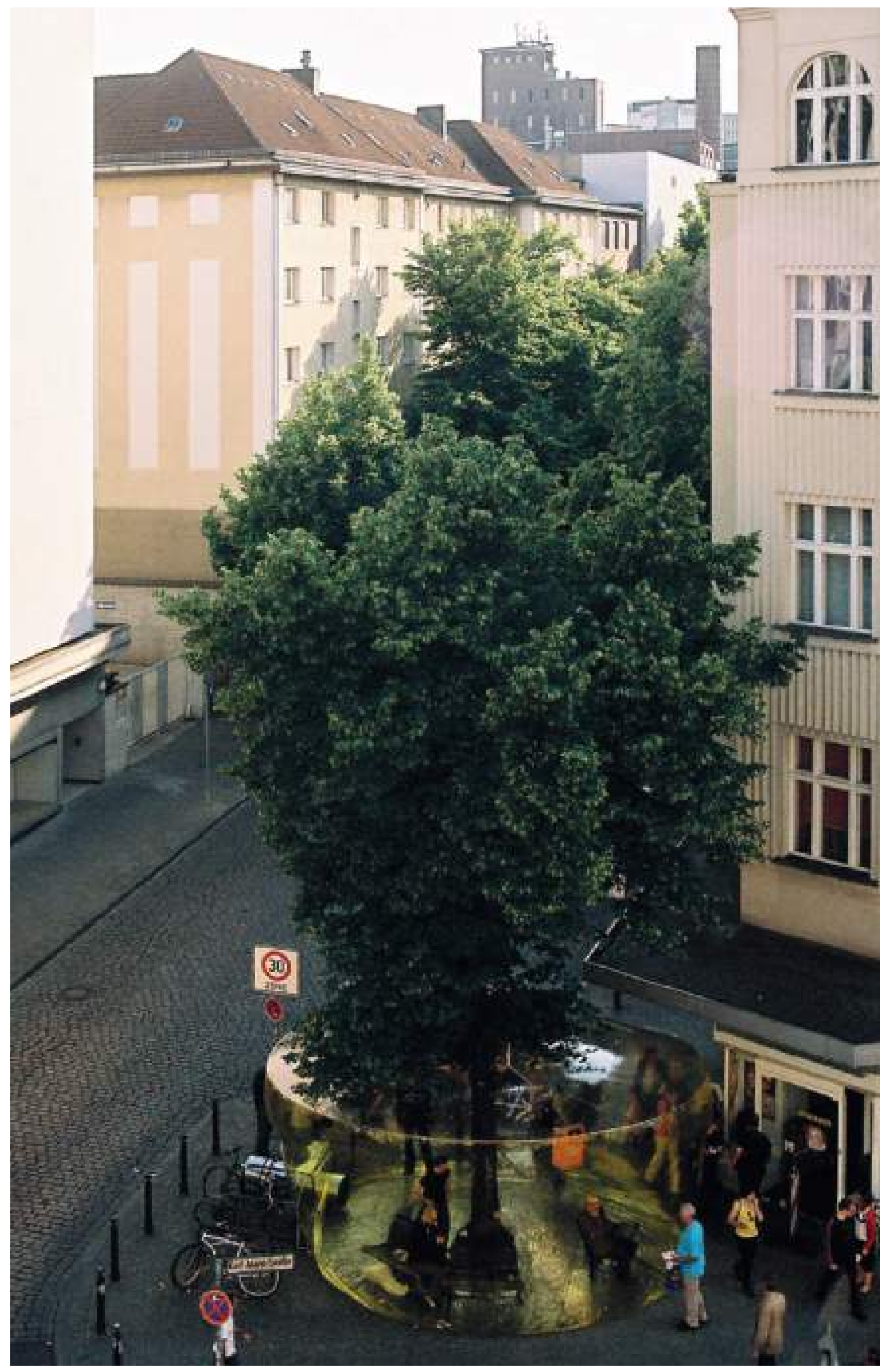

52 | The Journal of Public Space, 3 (2), 2018 | ISSN 2206-9658

City Space Architecture / UN-Habitat 

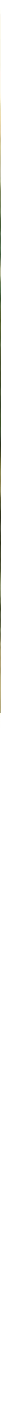

KARL MARX BONSAI is a joint project of Plastique Fantastique \& Architettura Sonora. www.architetturasonora.com

Photos: Marco Canevacci.

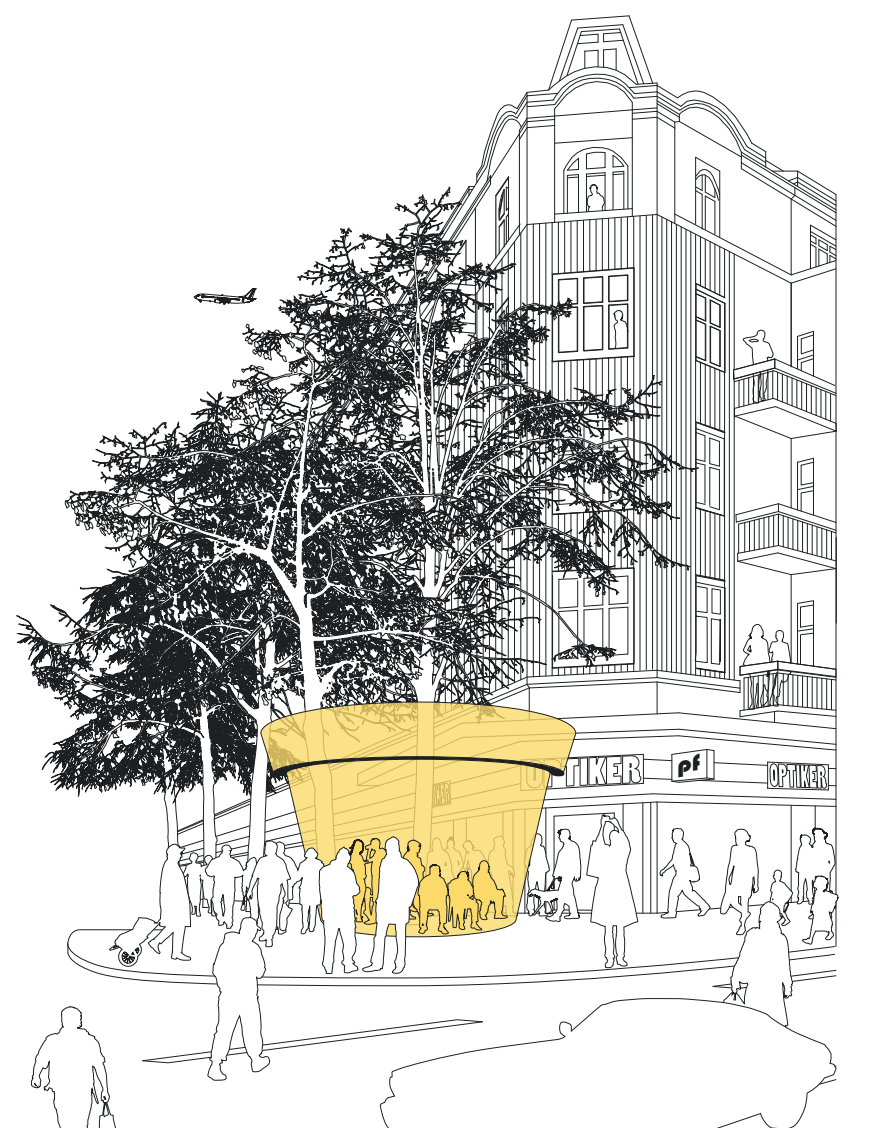




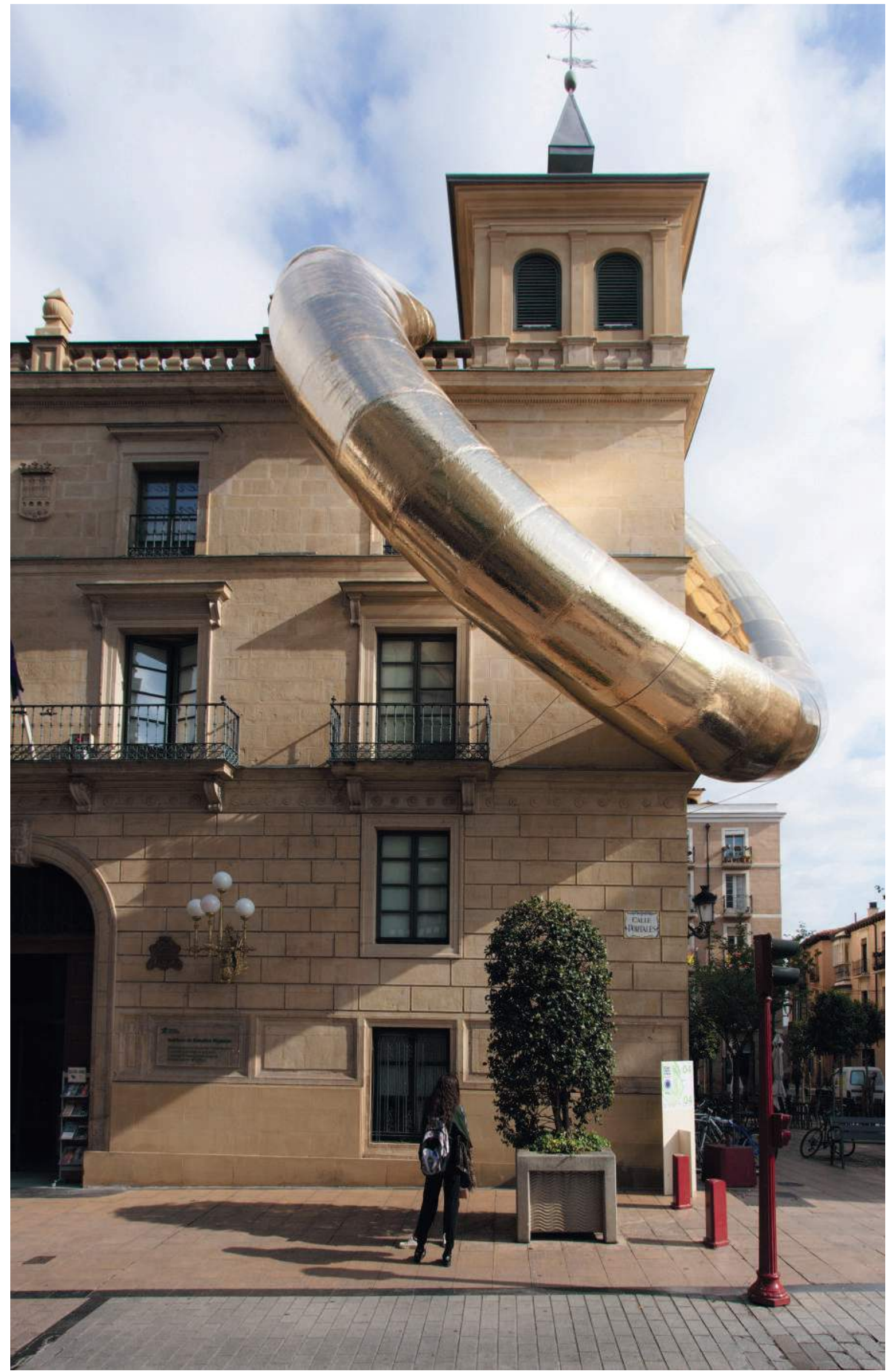

54 | The Journal of Public Space, 3 (2), 2018 | ISSN 2206-9658

City Space Architecture / UN-Habitat 


\section{RINGdeLUXE la Rioja}

CONCÉNTRICO, Logroño's International Architecture and Design Festival 2018

\section{https://plastique-fantastique.de/RINGdeLUXE-LA-RIOJA}

RINGdeLUXE - a glamorous piece of jewelry worn by the building of the former city hall of Logroño, the capital of the Spanish province La Rioja, currently housing the Instituto de Estudios Riojanos.

The pneumatic structure of striking dimensions quickly reveals it's lightness and simplicity. The soft shining leads the thread of associations from gangsta outfits towards an ingenuous love confession.

Not all that glitters is gold. Not all that vanishes is untrue.

The collective Plastique Fantastique realised this installation as part of the Concéntrico festival of architecture and design, which took place in Logroño from April 27th till May Ist 2018.

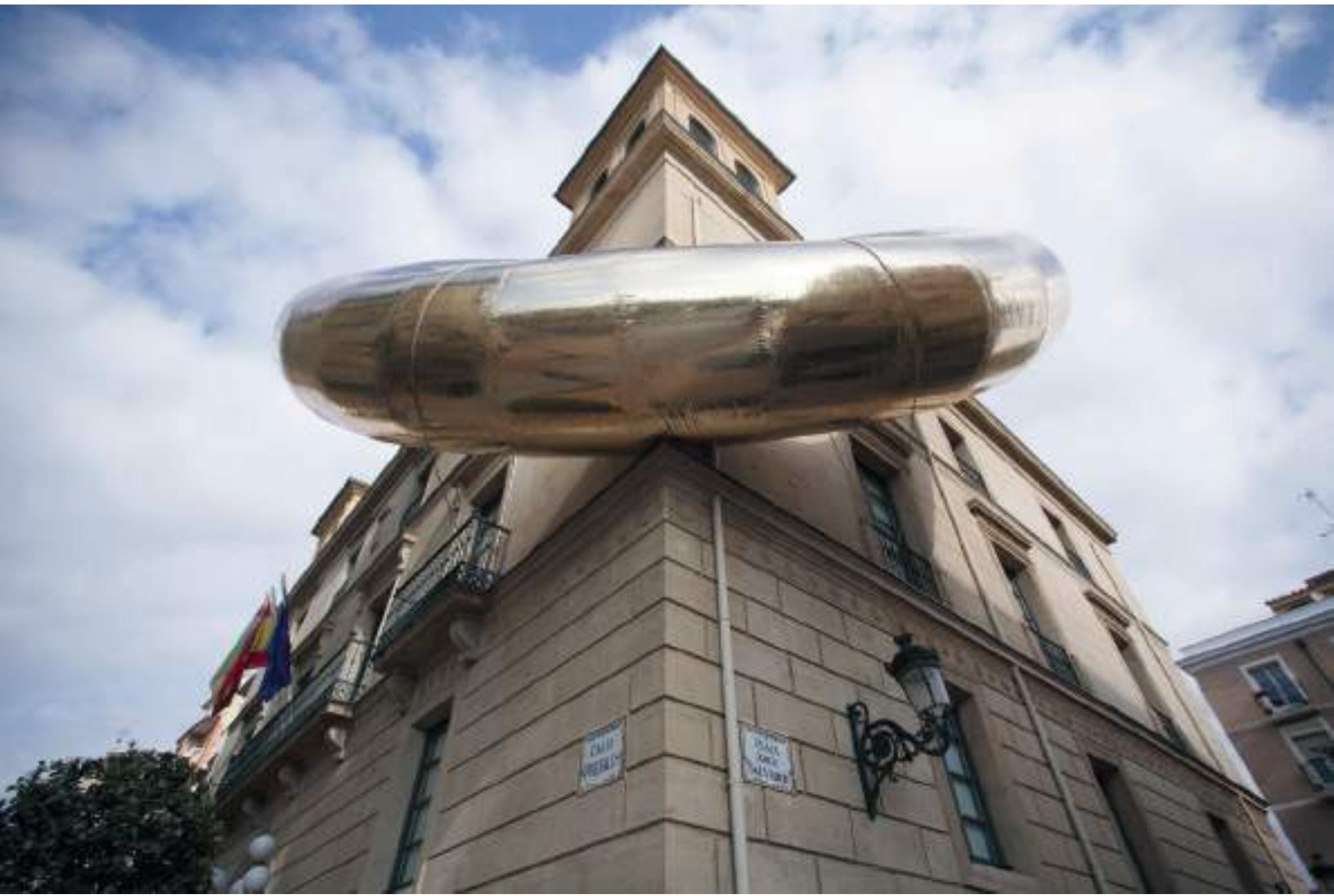

55 | The Journal of Public Space, 3 (2), 2018 | ISSN 2206-9658 


\section{LIVEBOAT - Chapter 5}

48 Stunden Neukölln, Berlin, June 2015

\section{https://plastique-fantastique.de/LIVEBOAT-CHAPTER-FIVE}

Taking his trident in both hands, Poseidon stirs the sea into a fury and lashes up rain and squall. Mast and sail are torn away, Odysseus is thrown overboard and buried under a wall of water. When he emerges gasping and sputtering, he somehow manages to clamber back aboard. A goddess, Leucothea, appears to him in the form of a bird. She counsels him to swim for it.

"Take my veil, tie it around your waist as a charm against drowning. When you reach shore, be sure to throw it back into the sea."

Homer, Odyssey, Chapter Five 
LIVEBOAT - Chapter 5 addresses the ongoing refugee tragedy in front of our borders and offers space for communication and discourses. After a long odyssey, an oversized lifeboat runs ashore on Tempelhof Airport. Inside the boat, multilingual extracts from Homer's Odyssey as well as fragments of refugee experiences are intertwined to a sound carpet.
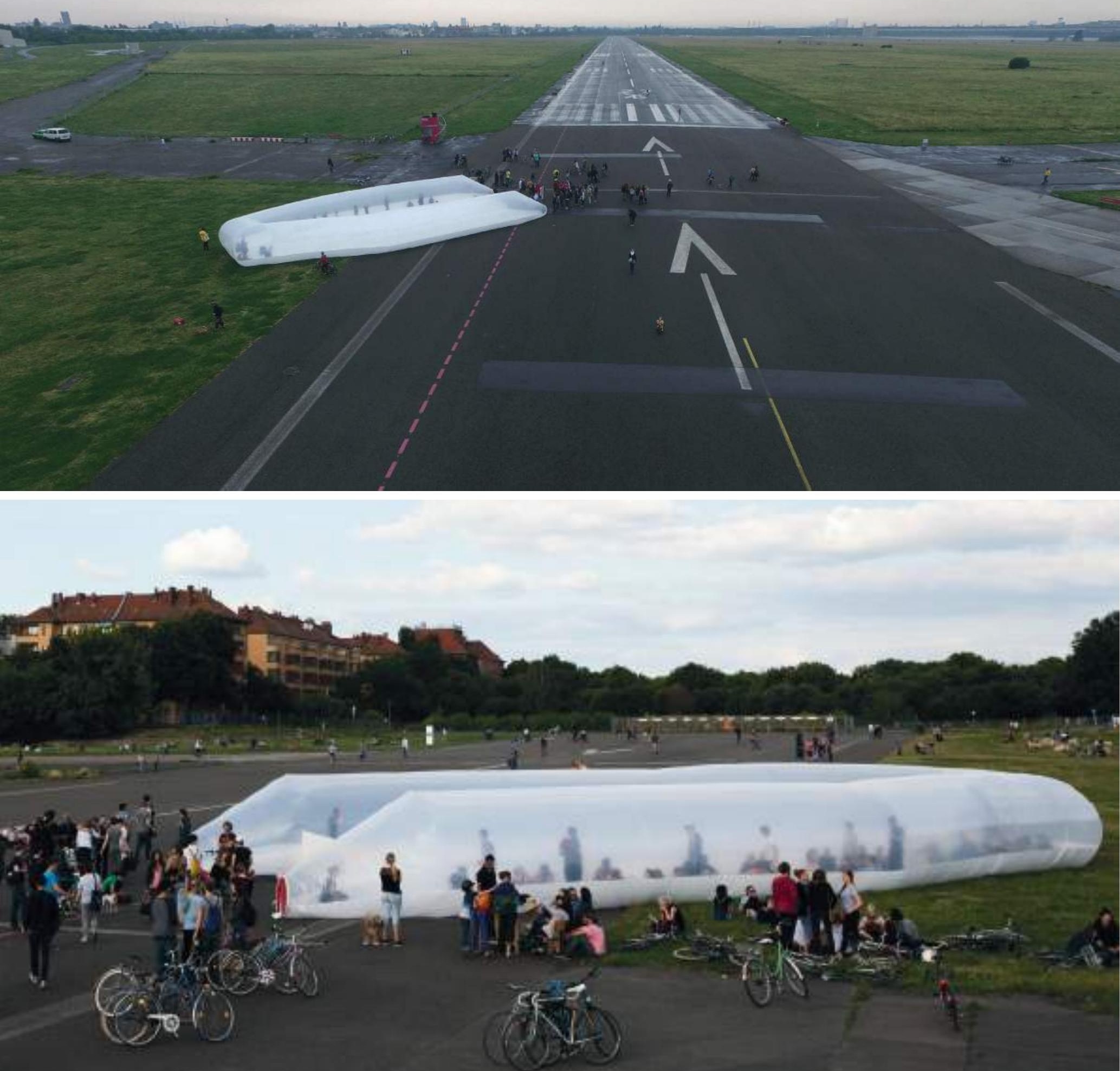

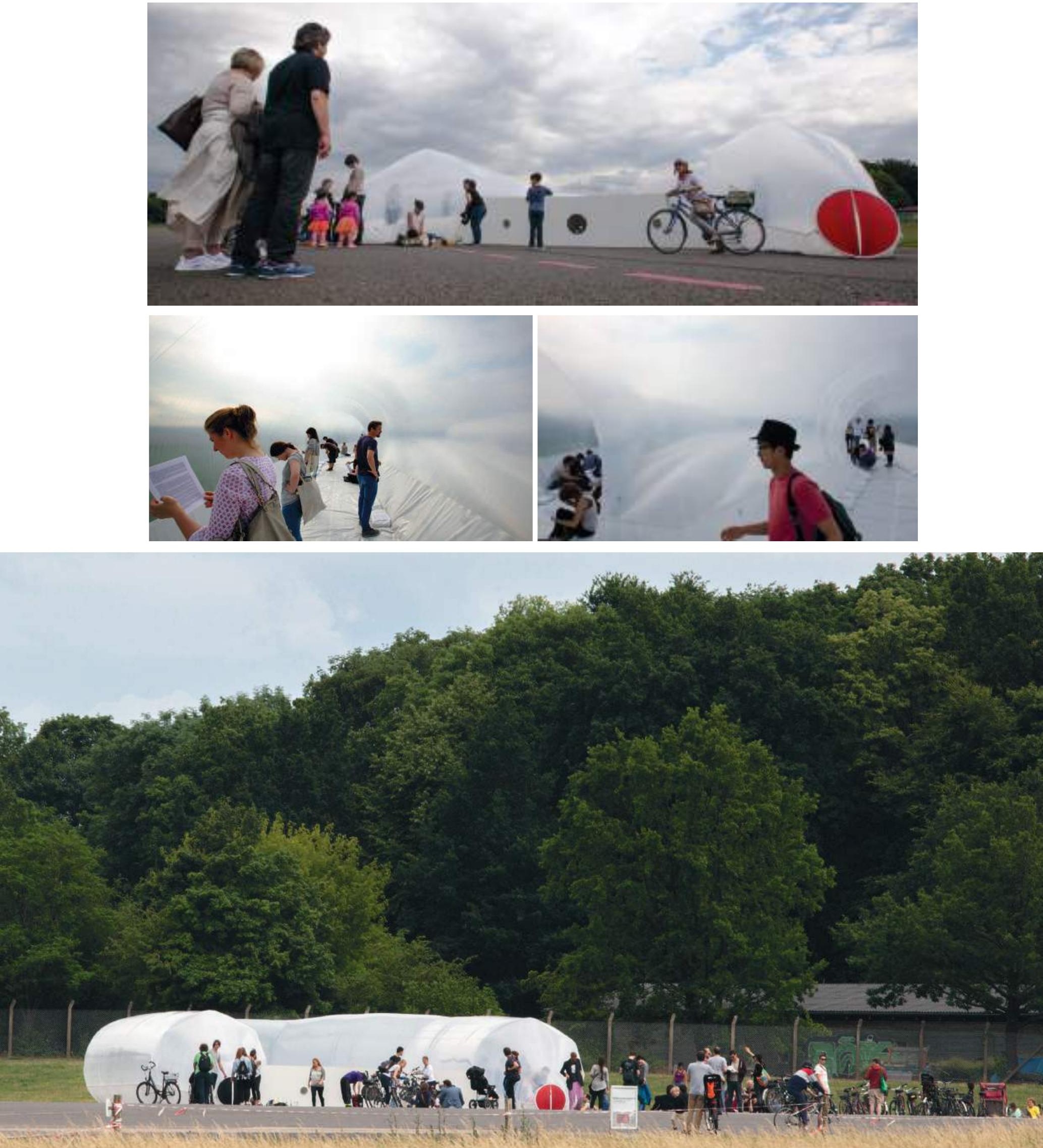

59 | The Journal of Public Space, 3 (2), 2018 | ISSN 2206-9658

City Space Architecture / UN-Habitat 


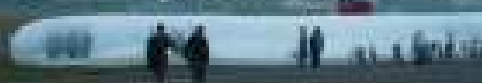

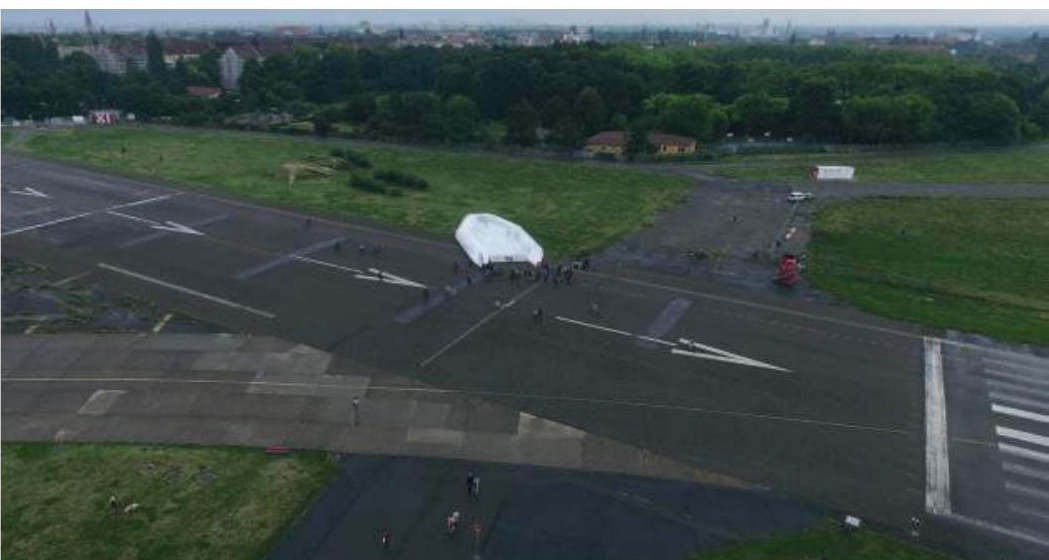

\section{Credits}

Concept: Marco Canevacci

Design:Yena Young

Sound design: Marco Barotti

Interviews: Hadmut Bittiger

Coordination: Steffi Goldmann

Team: Mirjam Dorsch, Stephanie Grönnert, Hugo Luque, Simone Serlenga, Gabriel Spera

Thanks to: Martin Steffens, Franz Höfner, Markus Wüste, Andrea Klahold, Herr Gessner, Homer

\section{Kindly supported by:}

Aktionsfonds Quartiersmanagement Schillerpromenade

Kulturnetzwerk Neukölln e.V.

Bezirksamt Neukölln Fachbereich Kultur

Stiftung Umverteilen! AG dritte Welt Hier!

Grün Berlin GmbH

60 | The Journal of Public Space, 3 (2), 2018 | ISSN 2206-9658

City Space Architecture / UN-Habitat 


\section{LOUD SHADOWS | LIQUID EVENTS}

OEROL FESTIVAL, Terschelling, The Netherlands

9 - 18 June 2017

\section{https://plastique-fantastique.de/LOUD-SHADOWS-LIQUID-EVENTS}

LOUD SHADOWS | LIQUID EVENTS is a collage made by artists coming from different backgrounds: dance, music, architecture. The team has been assembled as an experiment by Kees Lesuis - artistic director of the OEROL Festival — in order to give birth to a unique performance on the occasion of the 2017 edition of the festival.

The temporary space of Plastique Fantastique is monumental, yet mobile, soft and transparent. Its ephemeral skin influences the surroundings as much as its inner space offers a lucid view outwards. It is a magical place to merge dance, music and nature, challenging our perception.

The architecture of LOUD SHADOWS | LIQUID EVENTS offers four different stages and it is designed considering the peculiar position of every single tree of the area located within the Formerum forest, on the island of Terschelling. Each element of this site specific project is integrated into its environment: the first transparent spherical stage is pierced by a tree, while the second stage (the milky translucent one) is squeezed between tree branches and comes under the projection of their shadows. The ring connecting the two stages loops around pine and oak trees creating the third stage in its void. The fourth stage is the forest around the installation.

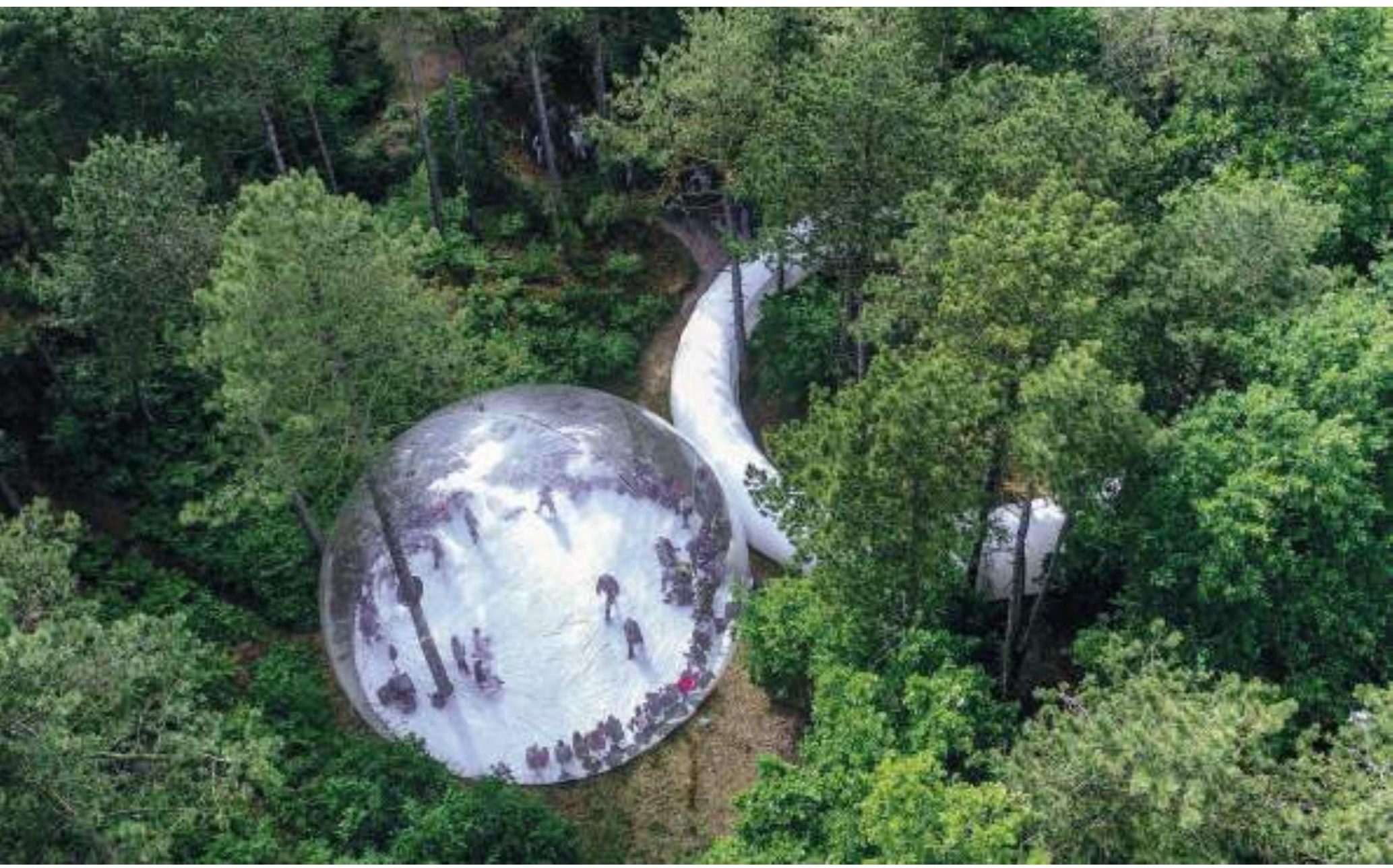

6I | The Journal of Public Space, 3 (2), 2018 | ISSN 2206-9658

City Space Architecture / UN-Habitat 


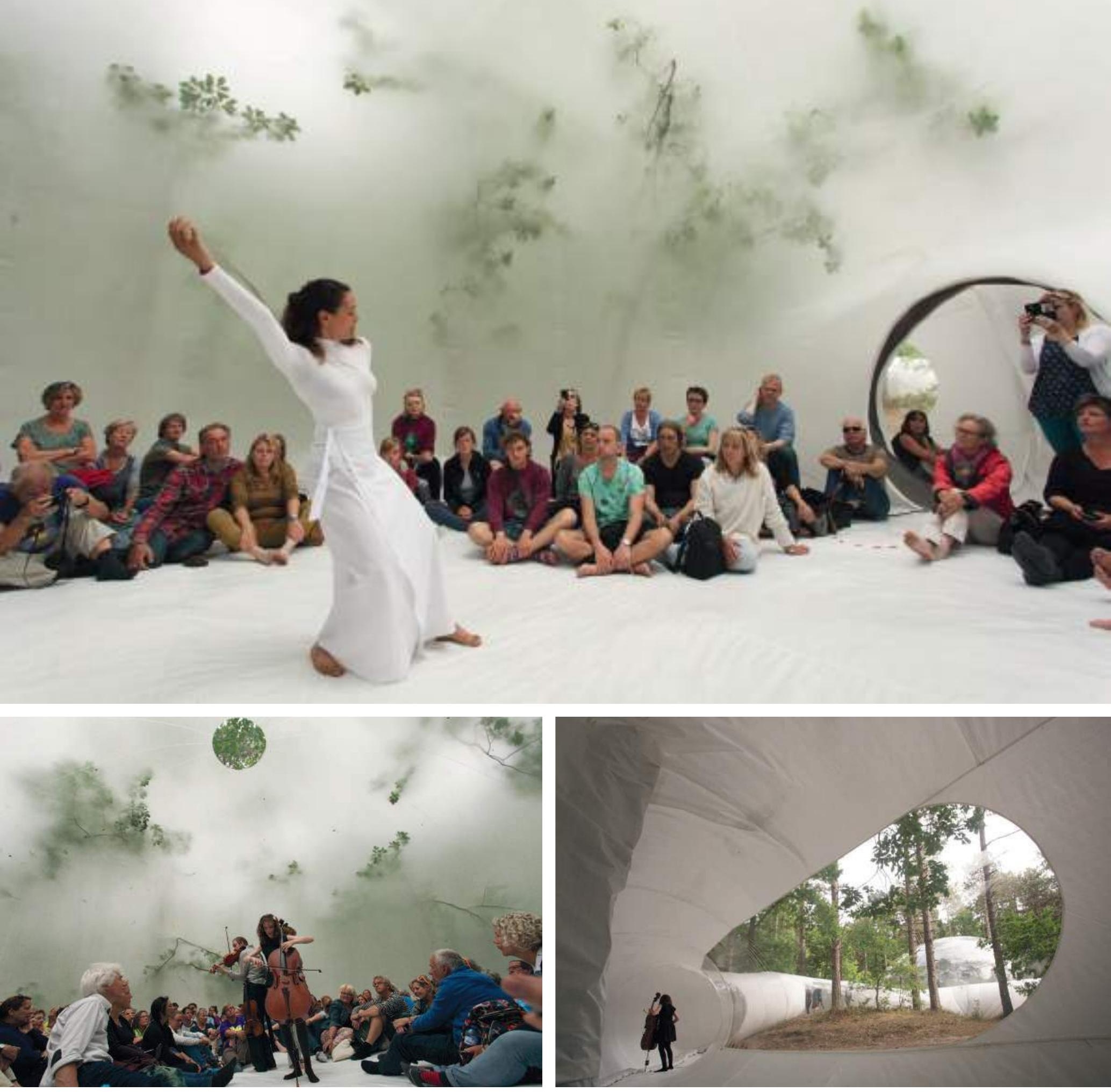

62 | The Journal of Public Space, 3 (2), 2018 | ISSN 2206-9658

City Space Architecture / UN-Habitat 

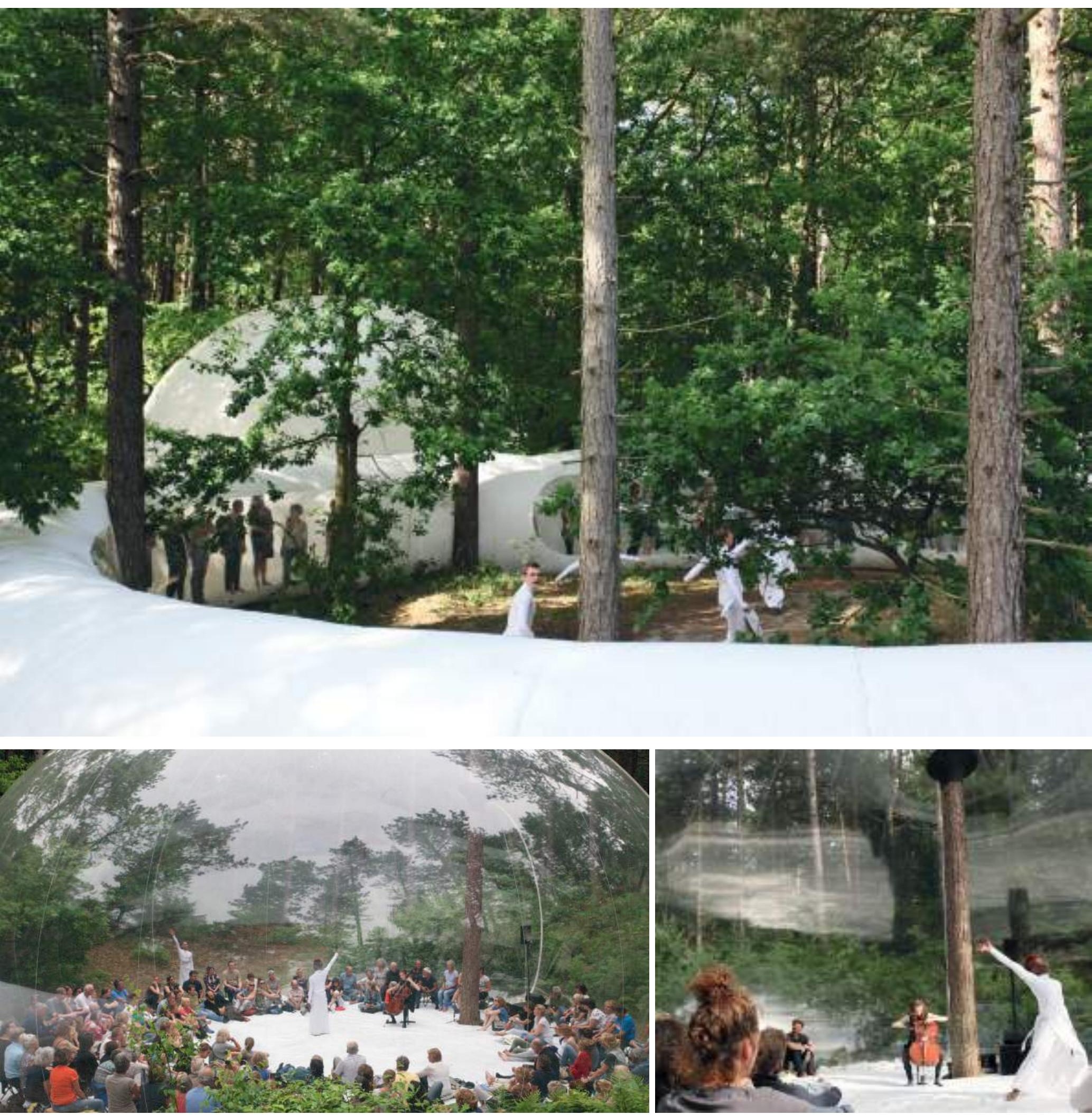

63 | The Journal of Public Space, 3 (2), 2018 | ISSN 2206-9658 

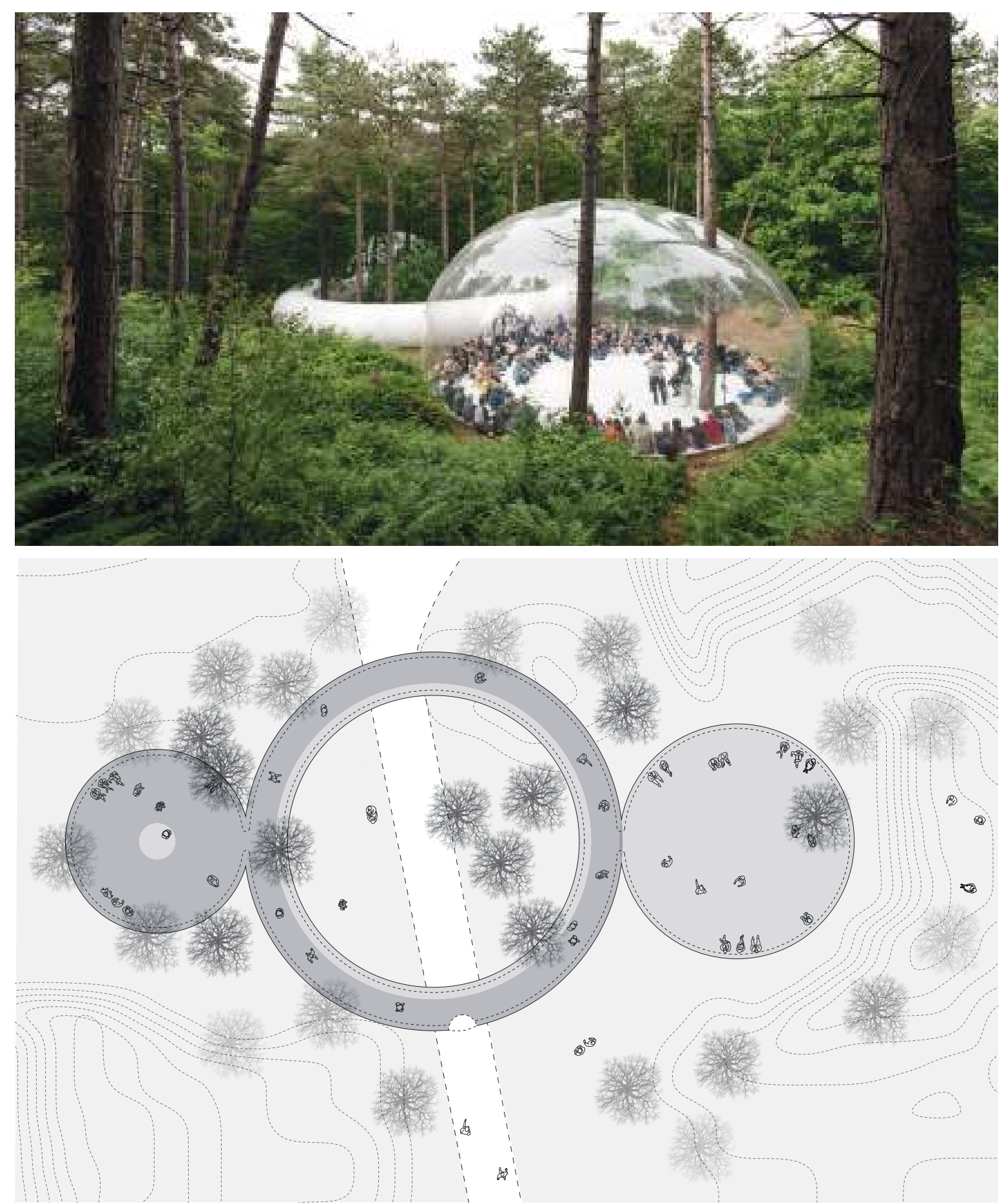

Inside this constellation the audience is free to circulate and choose its place in the transparent stage, the milky sphere, the inner circle, or the surrounding woods. These movements are encouraged by the musicians (The Stolz) and dancers (LeineRoebana), which are playing and performing simultaneously through the different stages. Even the composition (Kate Moore) is affected by unpredictable natural elements like birds singing, leaves rustling, wind gusts or rain drops - thus making each performance unique.

LOUD SHADOWS | LIQUID EVENTS is a joint project of Kate Moore, The Stolz, LeineRoebana and Plastique Fantastique.

Photos: Jelte Keur, Marco Canevacci. 


\section{SOUND OF LIGHT}

Urban Lights Ruhr 20I4, Hamm, Germany

\section{https://plastique-fantastique.de/SOUND-OF-LIGHT}

"Half of the human brain is devoted directly or indirectly to vision"

Mriganka Sur, Professor of Neuroscience, MIT

Imagine hearing the colours you perceive.

SOUND of LIGHT is a synesthetic sculpture which interprets and dynamically transforms sunlight into audio frequencies. It is a site specific installation designed for the former music pavilion in Hamm, Germany, which was built in 1912 .

A high-quality digital camera mounted on the top of the structure films the sky and divides it into six colours - RGB and CMY. The six hanging, coloured columns of the pneumatic structure - which stand for the primary RGB (red/green/blue) and secondary CMY (cyan/magenta/yellow) colour models - are designed to receive different frequencies and convert them from visible to audible sensory input. A series of woofers is fixed directly on the bottom of each column and convert the whole architecture into a giant vibrating loudspeaker.

SOUND of LIGHT is a composition of hue, saturation, and light. By mixing sound and architecture, the audience experience a unique oneiric reality through the superimposition of colours, shapes, sounds and vibrations. Visitors can also discover their own concert by changing their point of view - an individual spectrum.

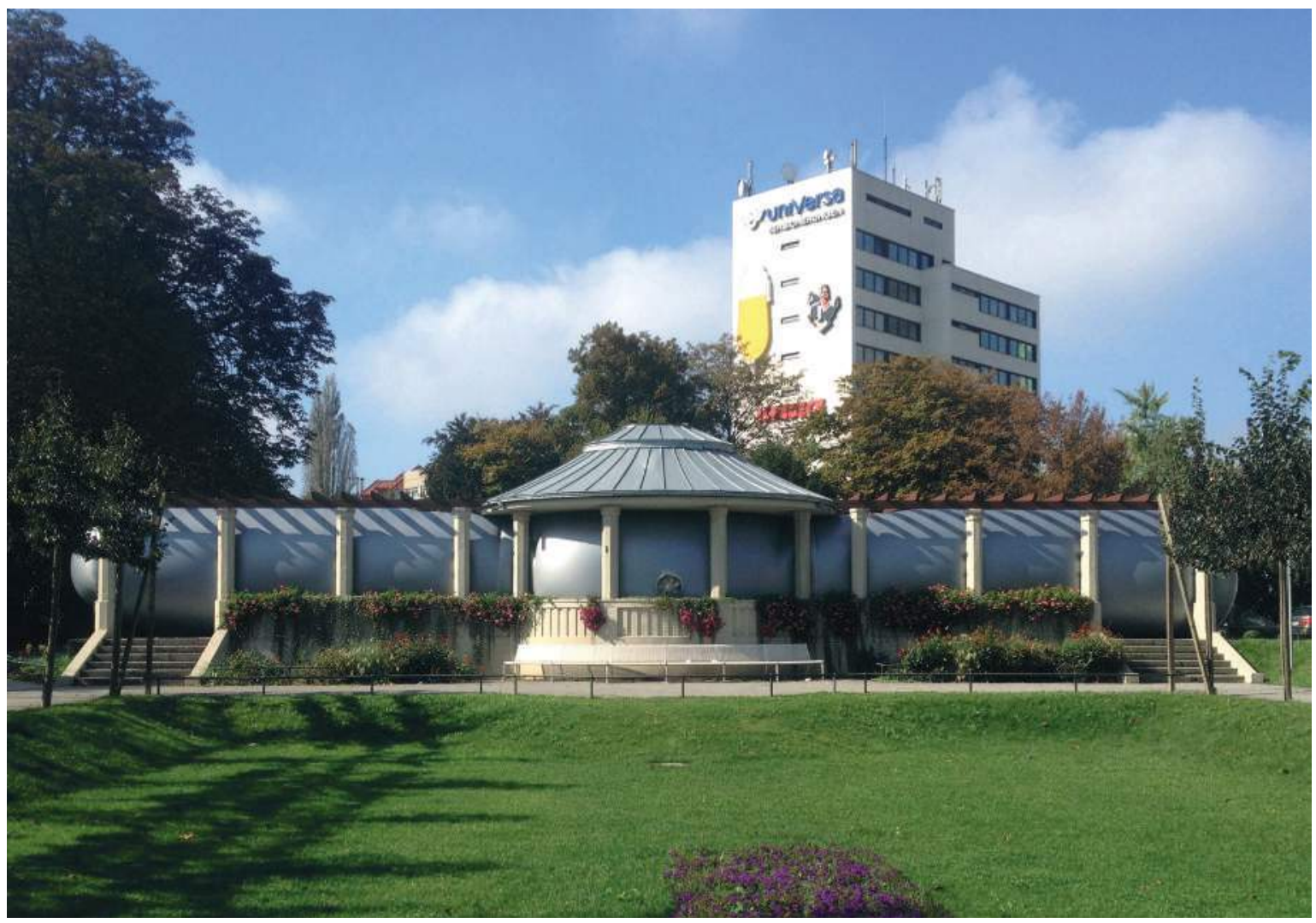

65 | The Journal of Public Space, 3 (2), 2018 | ISSN 2206-9658 City Space Architecture / UN-Habitat 

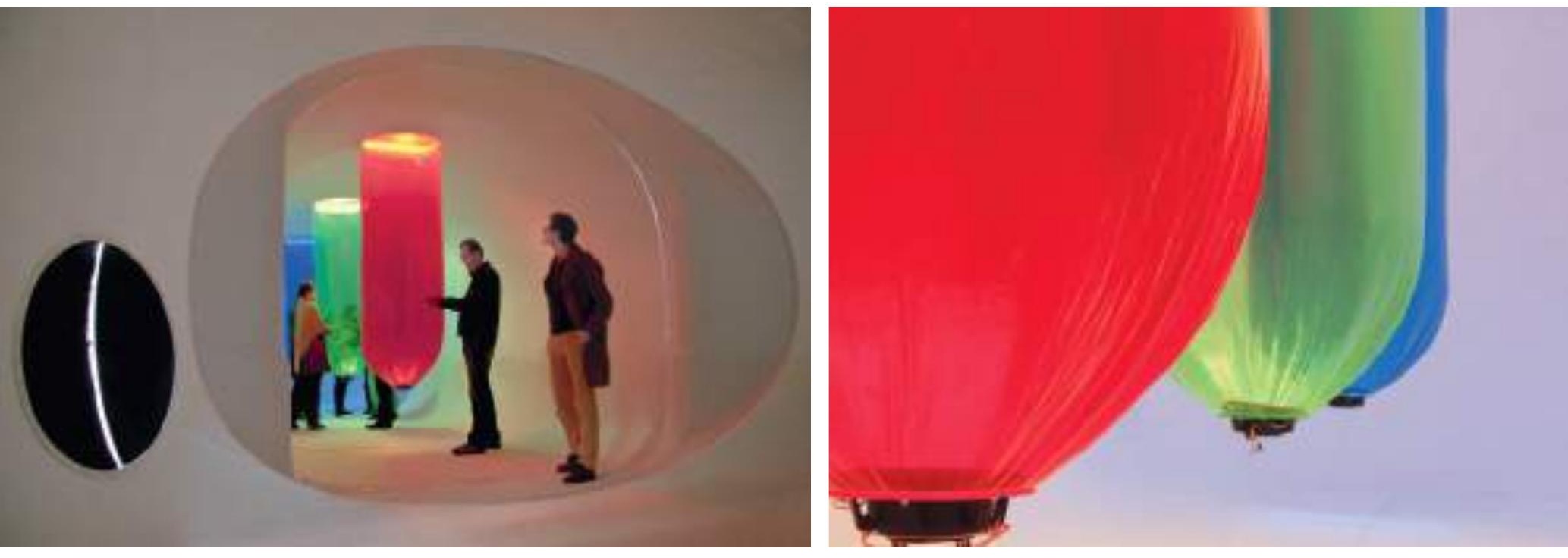

67 | The Journal of Public Space, 3 (2), 2018 | ISSN 2206-9658

City Space Architecture / UN-Habitat 
Soft, Sexy, Fantastic. Inflating public space

\section{Credits}

SOUND of LIGHT is a joint project of Plastique Fantastique and Marco Barotti. https://www.marcobarotti.com/

Photos: Marco Canevacci, Simone Serlenga

Video: Camilla Mantovani 


\section{STRAWBERRY ICE CREAM CONE - I 00\% MORANGO}

I 80 Creative Camp,Abrantes, Portugal

\section{https://plastique-fantastique.de/STRAWBERRY-ICE-CREAM-CONE-I00-MORANGO}

Plastique Fantastique held a workshop for 180 Creative Camp in Abrantes, Portugal. The participants consisted of people interested in urban arts from different backgrounds. The aim of the workshop was to create temporary space to offer a playful place and enhance communication. This allows the historical center of Abrantes to re-activate the vibrance and encourages people to be aware of the neglected urban space in town.

Photos: 180 Creative Camp, Miguel Oliveira, Marco Canevacci.

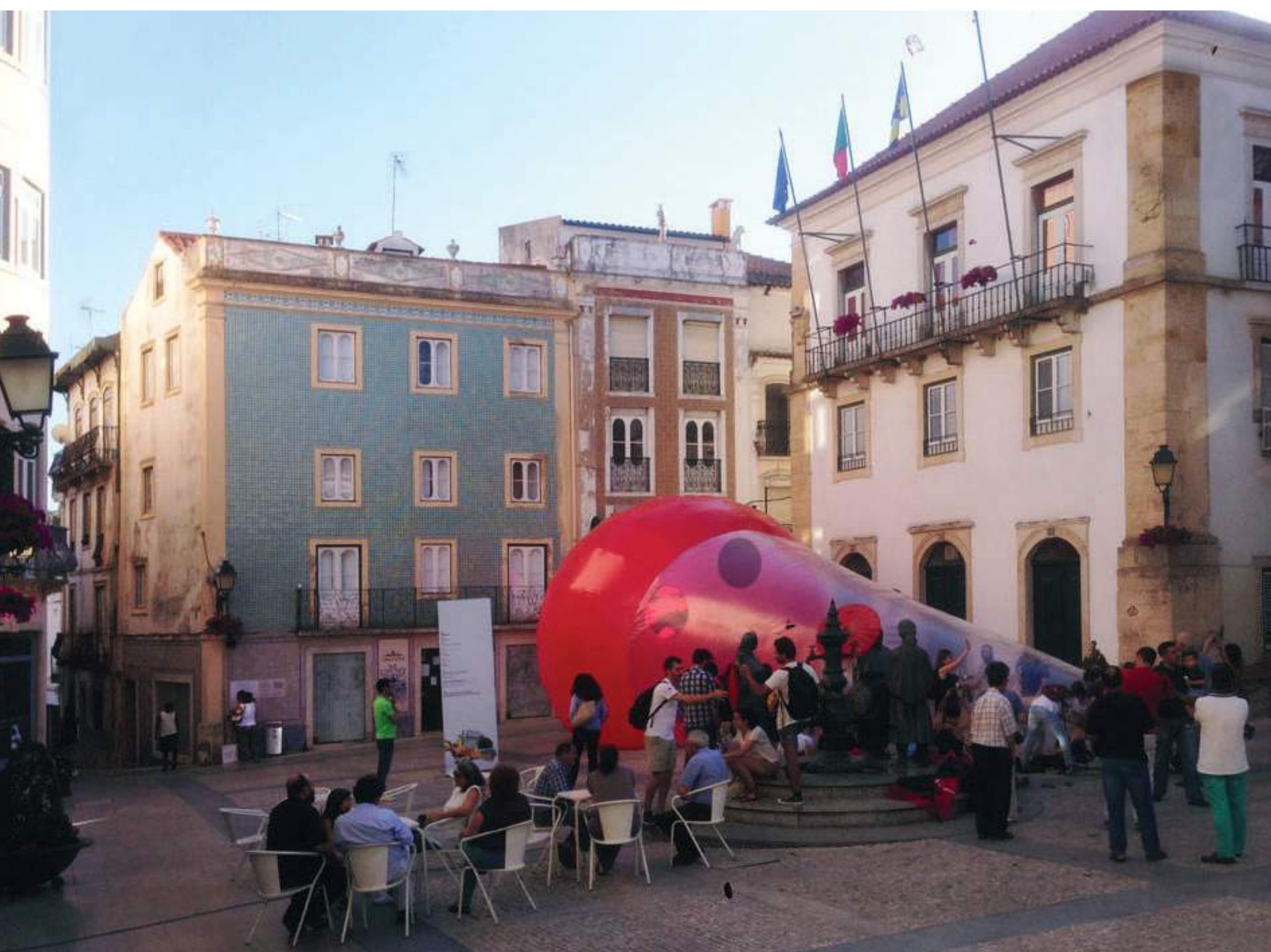



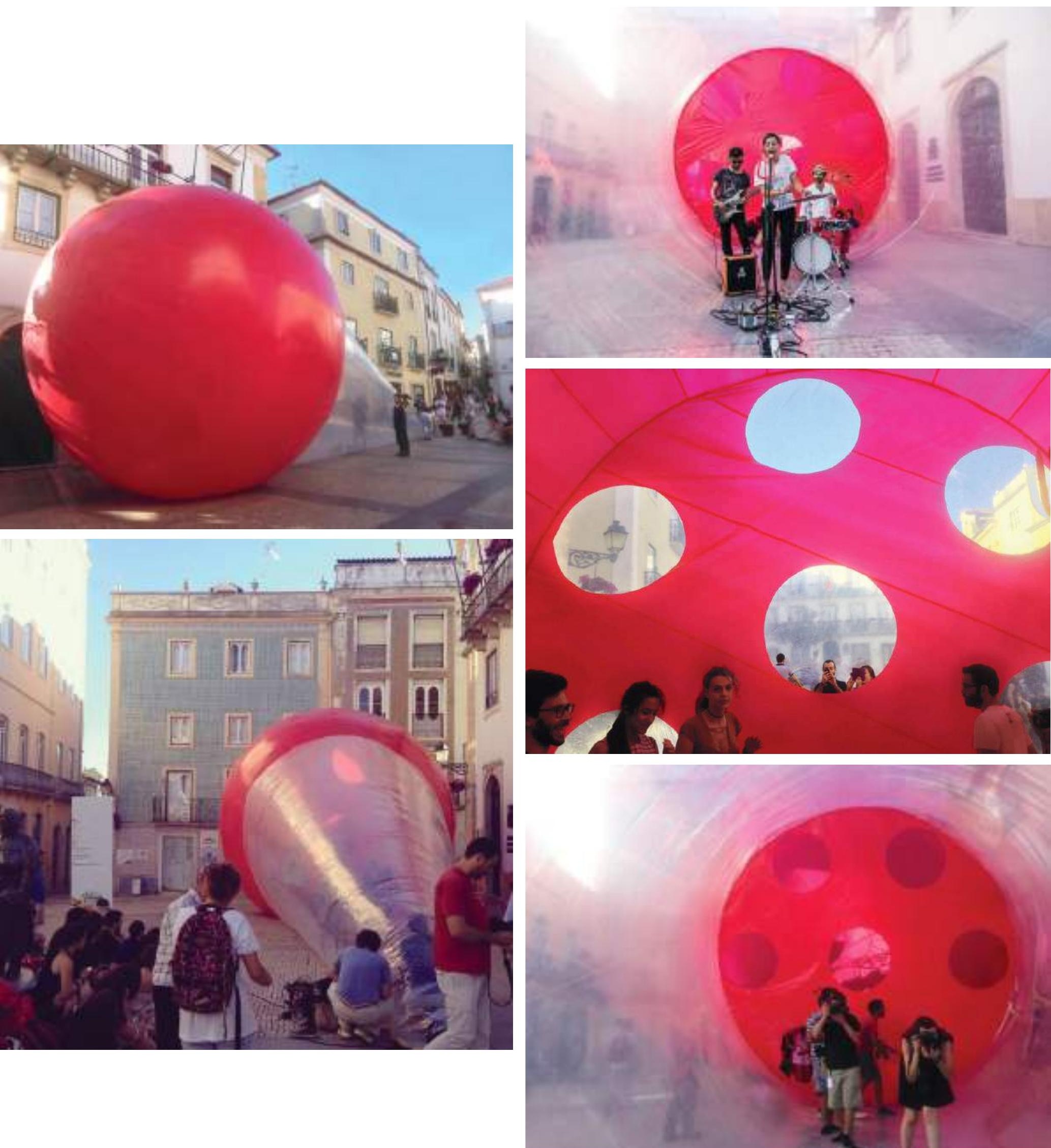

70 | The Journal of Public Space, 3 (2), 2018 | ISSN 2206-9658

City Space Architecture / UN-Habitat 


\section{superKOLMEMEN}

Helsinki Design Week 2016, Finnland

\section{https://plastique-fantastique.de/superKOLMEMEN}

superKOLMEMEN is an urban intervention, popping up temporarily for one week in the center of Helsinki, which will change the view and the perception of the place (Kolmen sepän aukio). The daily life scene, happening in the square that people pass by, sit, walk or drive through, will be converted to a playful environment where people can gather, talk, dance or relax. superKOLMEMEN will offer cultural experiences extending the summer fever to autumn - with a programs organised together with Helsinki Design Week.

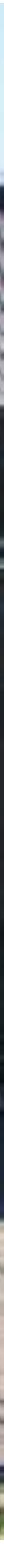

7I | The Journal of Public Space, 3 (2), 2018 | ISSN 2206-9658 

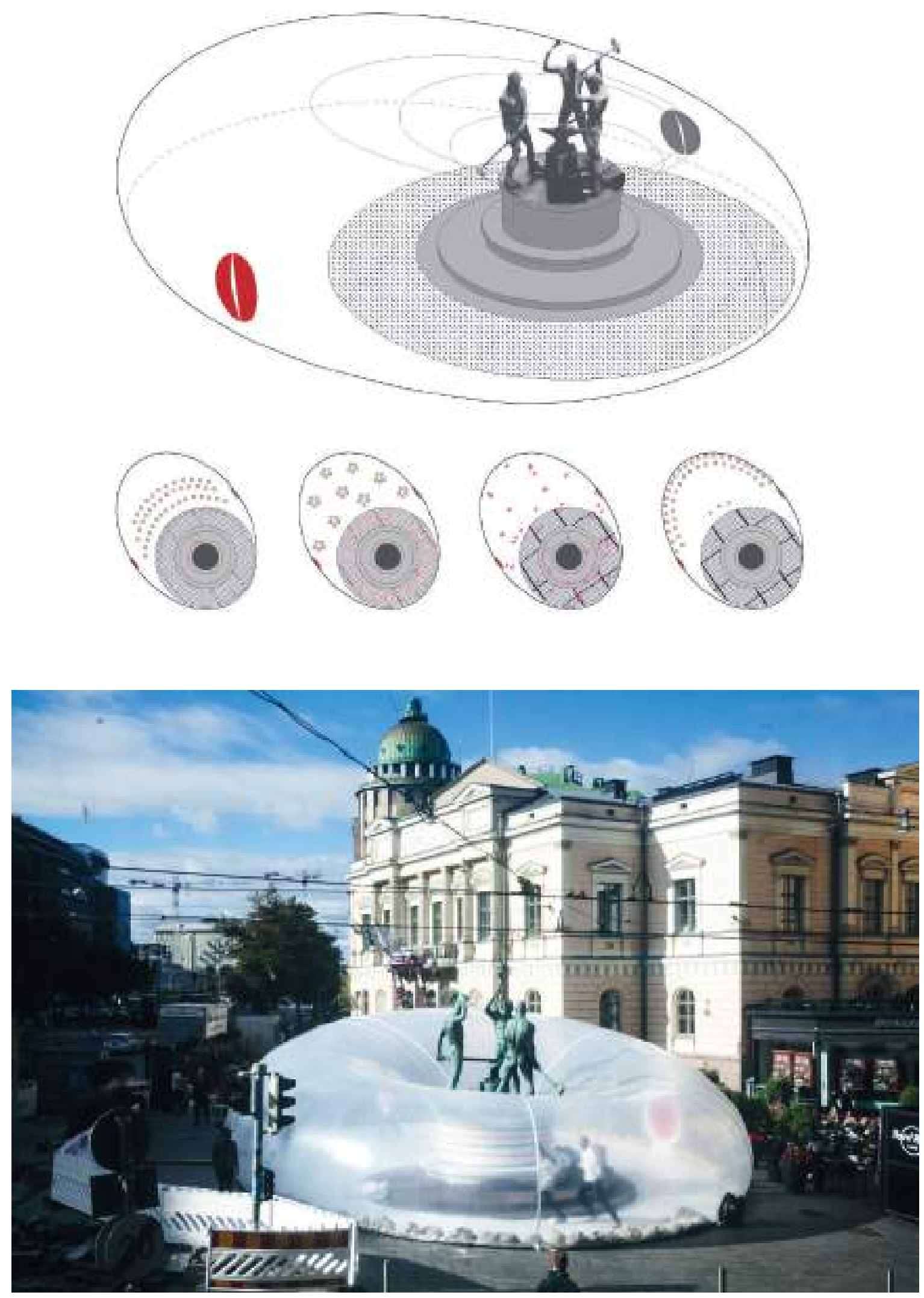

72 | The Journal of Public Space, 3 (2), 2018 | ISSN 2206-9658

City Space Architecture / UN-Habitat 


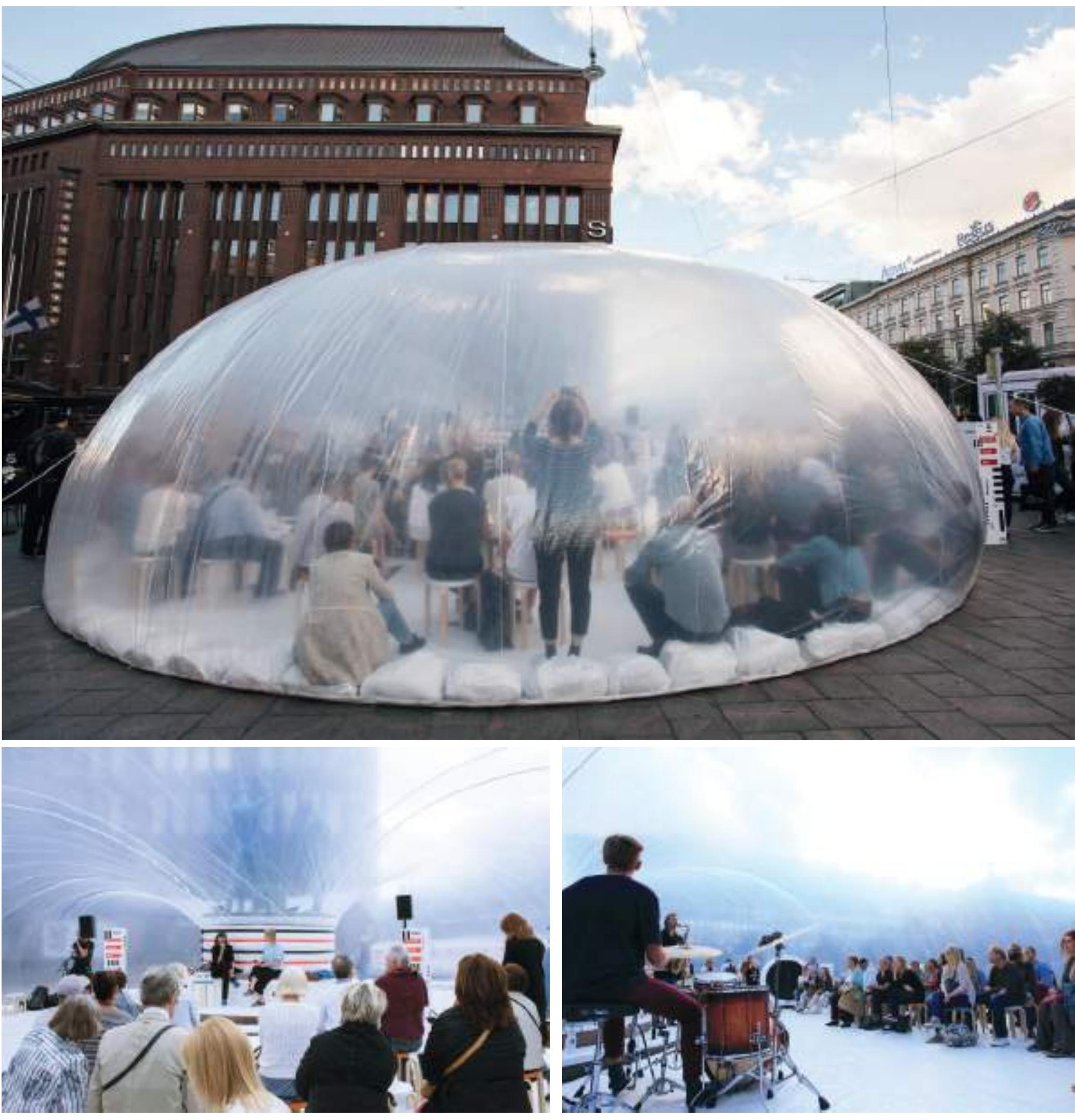

73 | The Journal of Public Space, 3 (2), 2018 | ISSN 2206-9658 


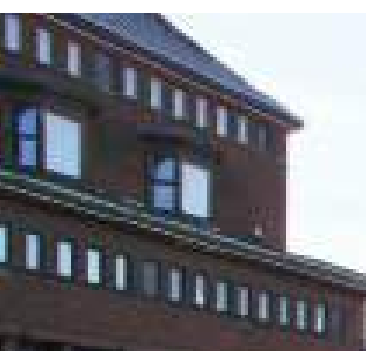


The Journal of Public Space

ISSN 2206-9658

2018 | Vol. 3 n. 2

https://www.journalpublicspace.org

\title{
Investing in Spaces: Luxury, Benevolence or Business?
}

Nabila Alibhai

InCOMMONS, Kenya

nabila@in-commons.com

with

\section{Elizabeth Thys}

Massachusetts Institute of Technology (MIT), United States of America

liz@limeshift.com

\begin{abstract}
This paper highlights the use of spatial transformation to shift the way people experience and engage with community. In essence, physical spaces can make people feel safe, well and like they belong. Moreover, they can infuse purpose into their habitual public and work-life experience. The examples shared include working with the Yale School of Management to help students reflect on and visibly communicate their role as leaders in business and society; the property development company Broder using public art to respectfully build a relationship with a neighborhood they are investing in; YouTube using the process of art creation to celebrate and communicate diversity in the workplace and lastly a public private partnership that brought together the Government, civil society and the private sector to address the erosion of trust and fear as a result of violent extremism in Kenya through a public art installation called Colour in Faith. Nabila Alibhai and her collaborators work to shift culture through investing in the transformation of spaces using art and urban design.
\end{abstract}

Keywords: public spaces, corporate spaces, employee engagement, values

To cite this article:

Alibhai, N. (2018). Investing in Spaces: Luxury, Benevolence or Business? The Journal of Public Space, 3(2), 75-96, DOI I0.3289I/jps.v3i2.IIII0

This article has been accepted for publication in The Journal of Public Space. Please see the Editorial Policies under the 'About' section of the journal website for further information.

This work is licensed under a Creative Commons Attribution - Non Commercial 4.0 International License https://creativecommons.org/licenses/by-nc/4.0/ 
Investing in Spaces: Luxury, Benevolence or Business?

"What is it that makes us move forward if it isn't happiness, and vision and solidarity."

This was how I began my talk to more than one hundred Corporate Executives from Godrej articulating that investing in spaces would be a great idea. Why start a conversation about public spaces with a conversation about human wellness and behaviour? The answer is obvious to most practitioners working on the design and planning of public spaces but not as obvious to corporations.

Investing in spaces, ties people together through a common experience. When designed deliberately, this investment can provide the optimum environment in which to thrive. For each community, the definition of an optimum environment will be different. For some it'll be an experience of joy, or being prompted by space to interact with the people with whom they share a joint purpose, or having visual reminders of that purpose, or simply having peace and quiet that will allow them to create.

Whatever it is - this psycho-social environment can be thoughtfully designed to reinforce positive cultural traits and to invoke a sense of community and shared identity. Each one of the examples below takes a cultural trait identified by a community - corporate or public - as aspirational, and brings that culture to life through thoughtfully transforming the space and involving the community in the creation of the space. The latter element, the process of co-creation, plays the important function of reinforcing belonging, and agency. Belonging is in fact an critical pre-requisite to participating in the improvement, cohesion and productivity of any community.

Our work with corporate communities in particular has shown that investing in the social values and notions of pleasure in the workplace experience manifest higher employee and client engagement. Examples presented in this paper will demonstrate how spaces address the gaping problem of employee engagement and highlight the innovative ways in which this concern has been approached and remedied.

In addressing the issue of employee engagement, we first analyzed the top factors that have been shown to improve engagement. Research points to the following as the top four issues to improve engagement: Role Design, Organizational Identity, Career Ladders and Community.

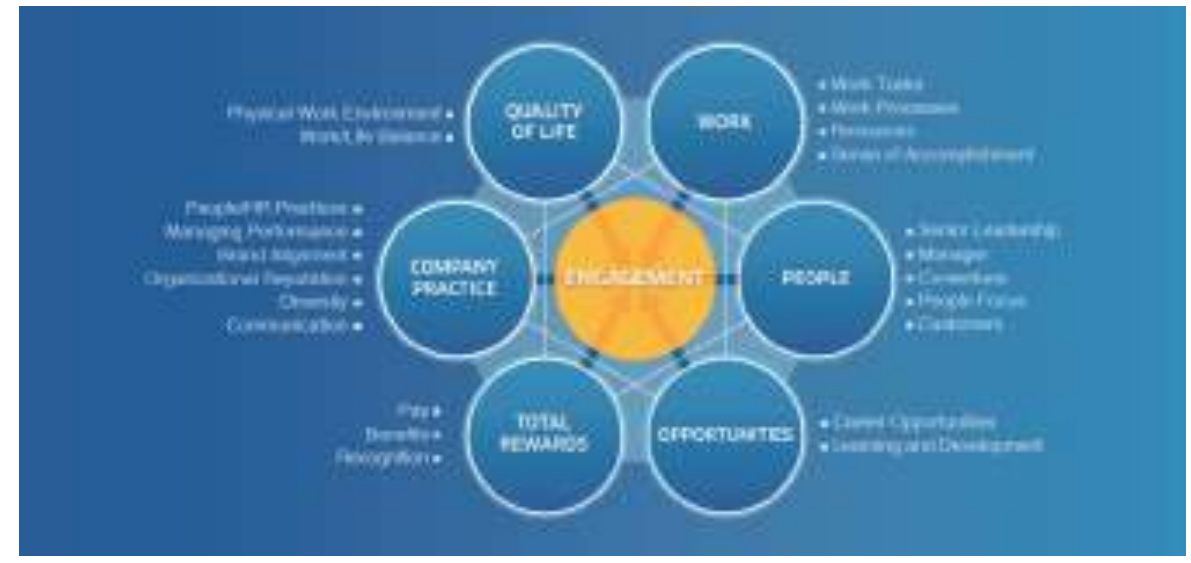

Figure I. Drivers of Employee Engagement.

Source: "Employee Engagement in Theory and Practice: Why Should You Care About Employee Engagement?" (2015) Microedge.com. MicroEdge, LLC. 


\section{COMPANY PROCESS \\ Role design \\ Organizational identity \\ Career Ladders \\ Community \\ Resource planning \\ Leadership \\ Compensation \\ Governance processes \\ Performance review}

\section{TOTAL MOTIVATION FACTOR}

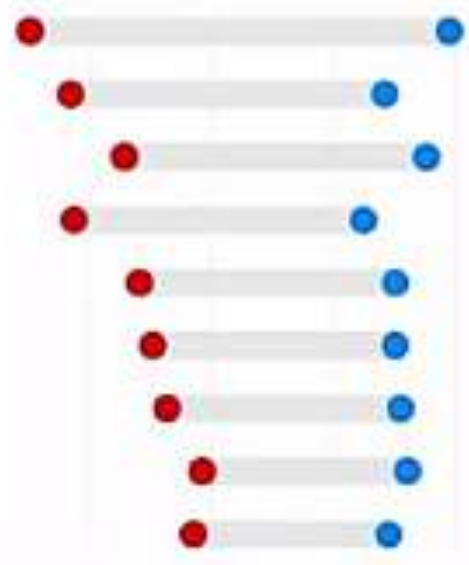

0. $25 \quad 50$
100

Haryard

Iusiness Reviove

Figure 2. Employee Motivation Ranked by Company Process.

Source: McGregor, Lindsay, and Neel Doshi. "How Company Culture Shapes Employee Motivation." Harvard Business Review, 20 Apr. 2016.

Through this lens, we view Role Design as more than the tasks assigned to the employee. Effective Role Design means an individual has a clear purpose within a collective context. It helps to set boundaries, empowers individuals within the collective and creates ownership by building out spheres of influence.

Focusing on improving role identity, our spatial transformation process influences both Organizational Identity and Community. When we align individual and organizational values and give people a sense of ownership in the company, employee engagement drastically improves.

Spatial design is not just about public good and benevolence but in fact is good business. In the case studies presented here we see aesthetic intervention in spaces, having the following effects:

$\checkmark$ Providing a gesture or exchange, a feeling of being part of something greater.

$\checkmark$ Visually describing a higher aspiration.

$\checkmark$ Enhancing employee wellness, motivation, integration, retention.

The company limeSHIFT has worked on several spatial interventions focused on helping employees connect with their own senses of purpose and connect with the people and environment around them, connecting people, place and purpose. The most relevant ones, described in the following pages, are:

- Espejismo. Reinforcing leadership in business and society, by artist Yazmany Arboleda

- Responsible development in a new neighborhood, by artists Ellen Rutt and Patrick Ethen

- Integrating and representing a diverse team, by artis Miguel Arzabe

We present also Colour in Faith - http://www.colourinfaith.com/ - a project of inCOMMONS, which invited religious communities to paint their sacred spaces in "optimistic yellow." 


\section{CONCLUSION}

Investing in space means working through the complexities of political, economic, social, and cultural interests. This paper has shown that in our present era of the modern world economy, it makes corporate sense to invest in and sustain local forms and practices of social, economic, and cultural "luxury." Sustainable business presence, practice, and profits relies upon a careful understanding that clients perceive luxury also as social wellbeing. In each case study above, the projects stakeholders were enriched in a variety of ways: their client's knowledge, ideas and practices for smart investment and both the stakeholder and the client produced new understandings of how corporate relations should be reconsidered to suit this investment approach.

In each case a basic process was employed:

I Identifying the aspirational culture with the community and it's leadership;

2 Designing an experience with an artist and community builder in order to meet these objectives,

3 Guiding participants through a applied process that allowed them to practice the values;

4 Culminating the process by completing a spatial transformation created by applying behaviors that reinforce specific cultural traits e.g. collaboration, participation, creativity.

What remains evident is that investments in spaces are evolving to enable corporate and non-corporate communities to deliver on luxury, benevolence and business.

\section{References}

Interview with Pastor Onesmus Chakaya Keverenge, PAG Makina Church, Kibera. 6 February 2018. Availabe at: https://www.linkedin.com/pulse/want-improve-employeeengagement-think-people-place-purpose-thys/

inCOMMONS is a company that develops and invigorates public spaces and builds collective leadership. inCOMMONS's New York-based sister company, limeSHIFT, uses the same principles and embeds artists into workplaces to make them more happy, purposeful and creative. Their work has been featured in a 2017-published TED Talk, lectured about at Harvard University and the Massachusetts Institute for Technology and featured in notable press outlets including the New York Times, The Guardian, BBC, Al-Jazeera, DOMUS Magazine, the Smithsonian Magazine, among others.

http://limeshift.com/

http://www.in-commons.com/ 


\section{Espejismo. Reinforcing leadership in business and society}

Client:Yale School of Management (SOM)

Artist:Yazmany Arboleda

The mission of the Yale School of Management is to educate leaders for business and society. The following three objectives shape how Yale SOM puts its mission into practice:

I. Be the business school that is most integrated with its home university

2. Be the most distinctively global U.S. business school

3. Be recognized as the best source of elevated leaders for all sectors and regions. limeSHIFT worked to activate SOM's mission through art.

The scope of work, defined through interviews with the Dean, several professors and the student community, was to create an interactive experience where diverse groups are called on to lead, create and participate. The art piece was to address the following ideas:

- The value of social impact for business

- Understanding the significance of the individual within the whole

- SOM's role within the Yale community and globally as a thought leader

- Authentic engagement among Yale SOM students

- More creativity and freedom within the SOM student experience

- The relationship between physical and social and the need to create a safe space for open dialogue.

Yale School of Management launched ESPEJISMO:A Festival of Borrowed Reflections, an artistic collaboration with Colombian-American artist and limeSHIFT cofounder Yazmany Arboleda.
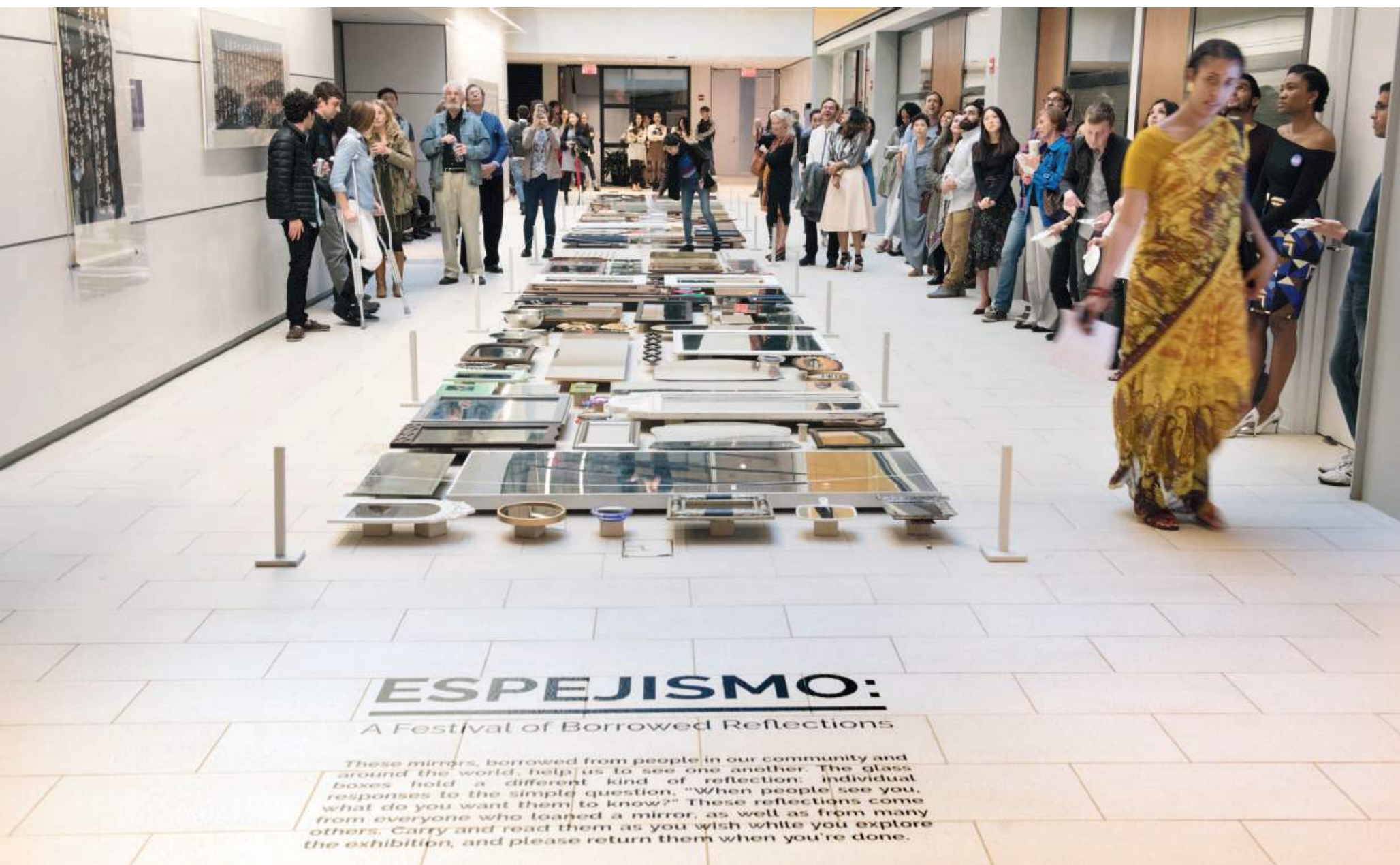

79 | The Journal of Public Space, 3 (2), 2018 | ISSN 2206-9658

City Space Architecture / UN-Habitat 


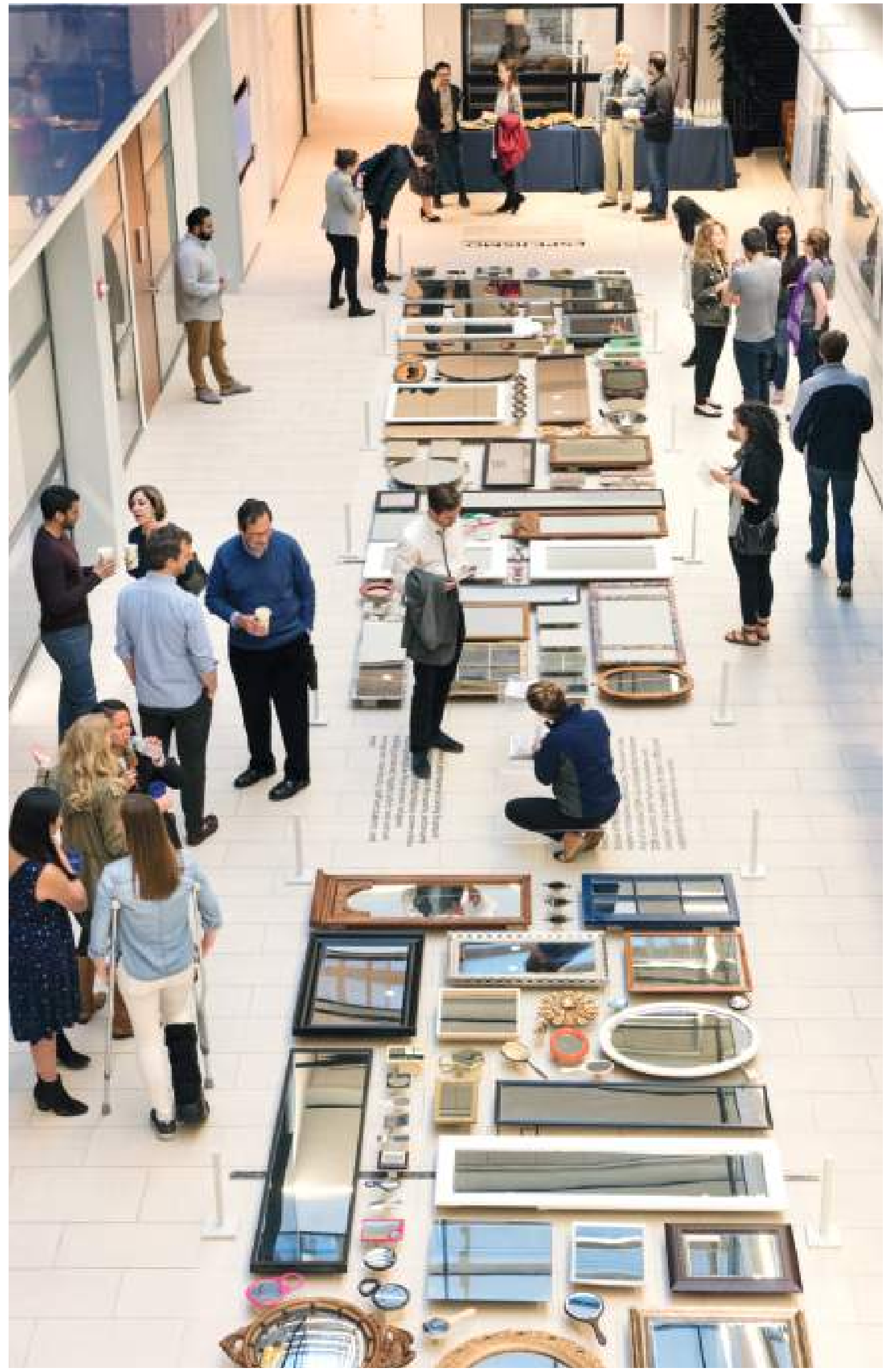

80 | The Journal of Public Space, 3 (2), 2018 | ISSN 2206-9658

City Space Architecture / UN-Habitat 


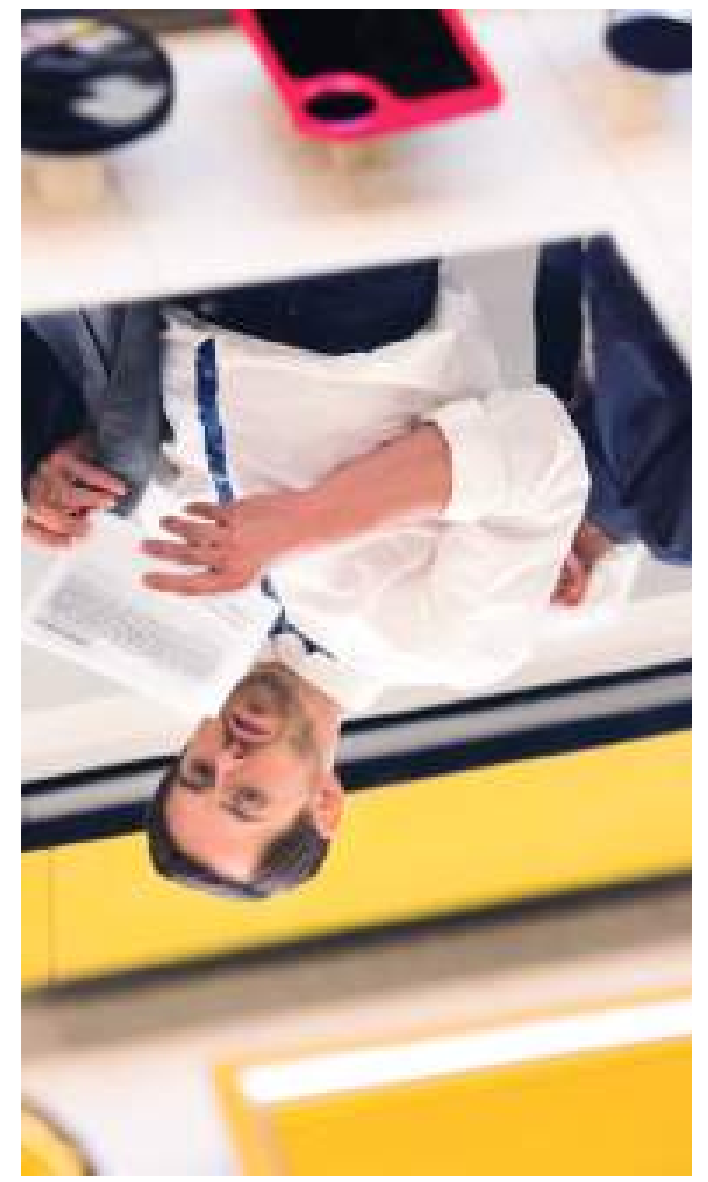

The art manifested as a digital platform and physical installation. Espejismo filled the Bekenstein Atrium of the Yale School of Management with mirrors borrowed from Yale students, New Haven residents, and communities around the world.

Laid across the floor of the atrium, the mirrors transformed the space into a garden of reflections that invited viewers to consider the perspectives of others. Eight more faculties were inspired to join the effort, along with 16 local philanthropic organizations.

The students sourced over 300 reflections and garnered over 200 mirrors in one week. The event was seen by hundreds of people in person, and thousands more online and was highlighted for it's message and impact in the regional press.

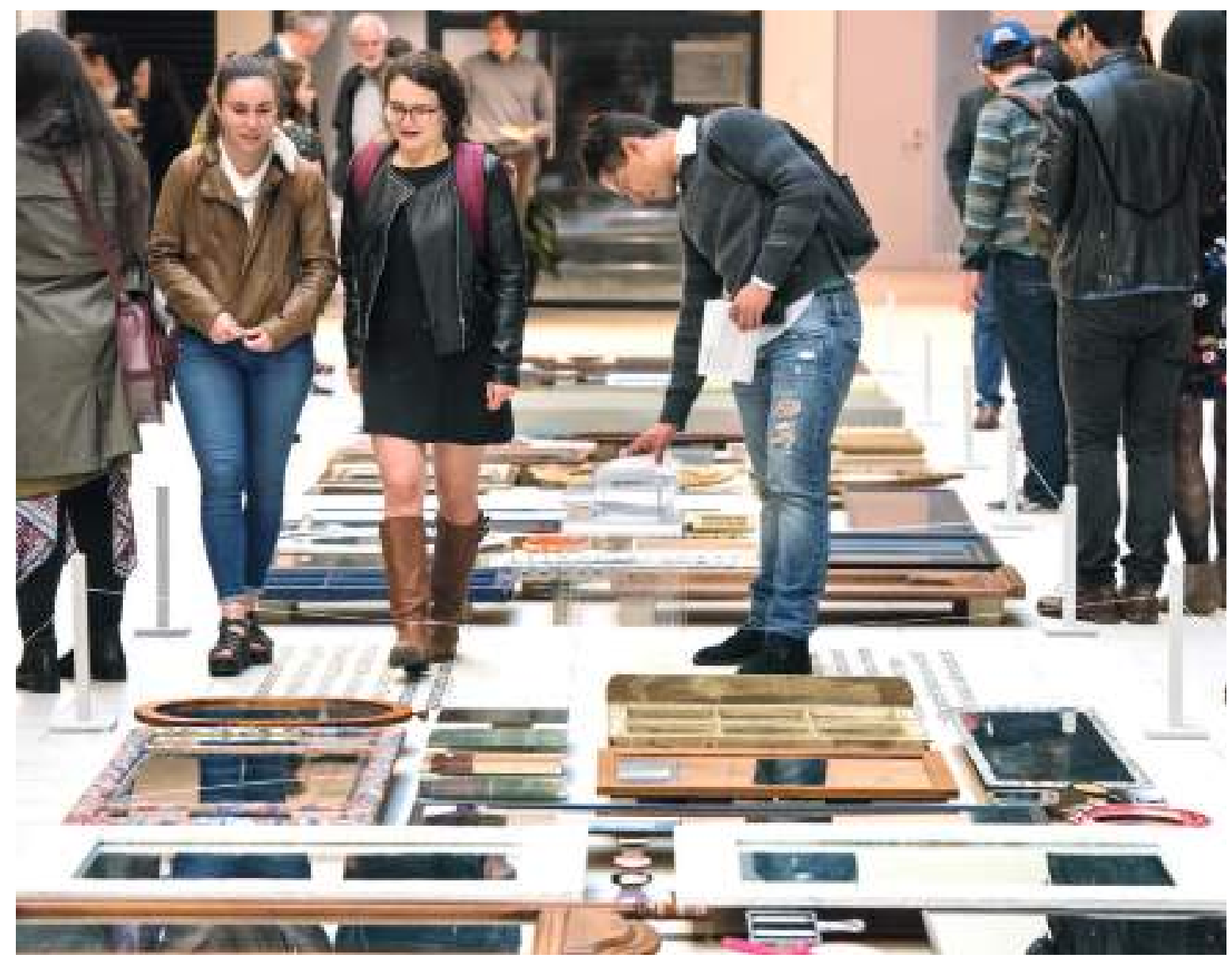

8I | The Journal of Public Space, 3 (2), 20 I8 | ISSN 2206-9658 City Space Architecture / UN-Habitat 


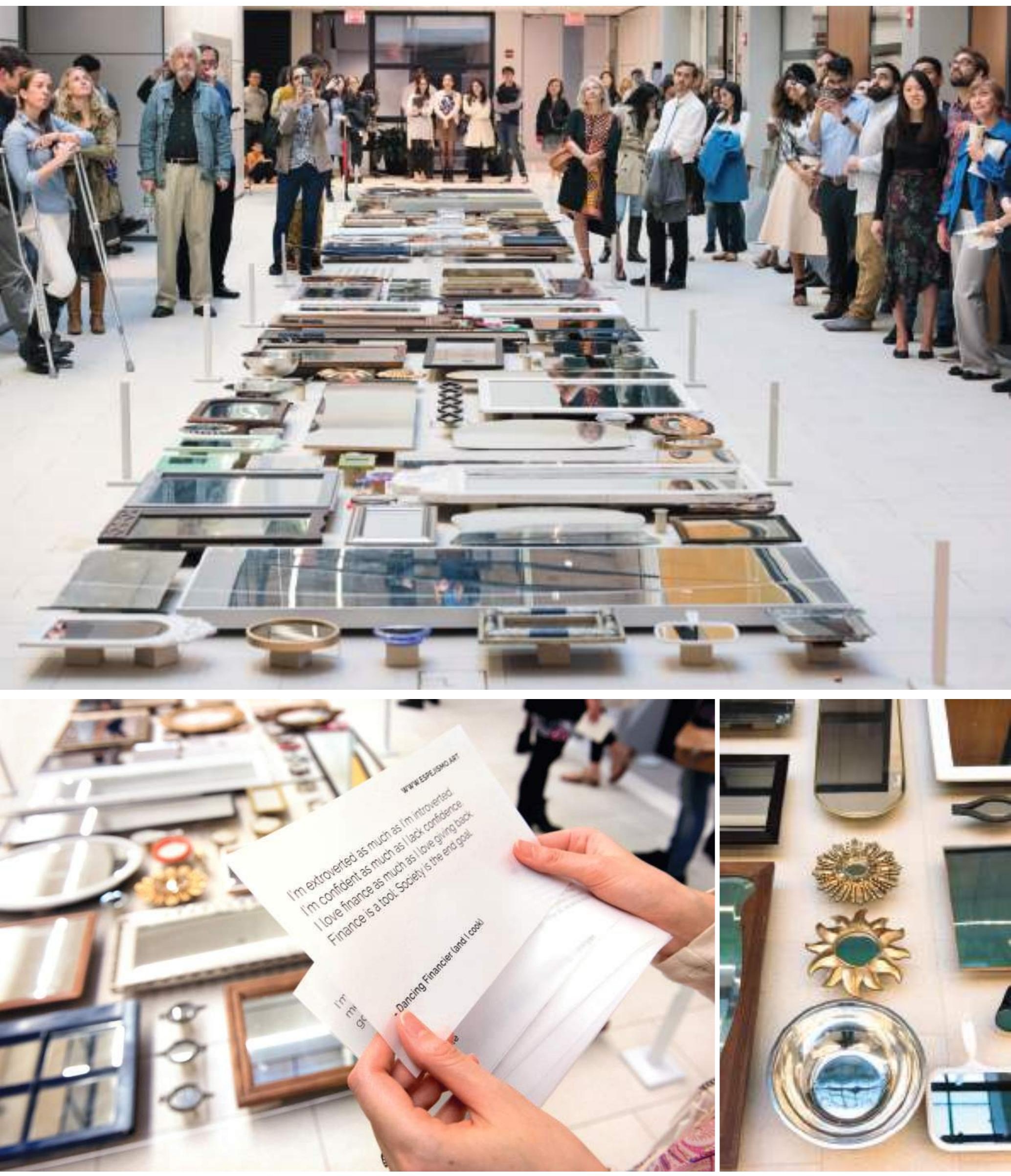

82 | The Journal of Public Space, 3 (2), 2018 | ISSN 2206-9658

City Space Architecture / UN-Habitat 
Nabila Alibhai with Elizabeth Thys

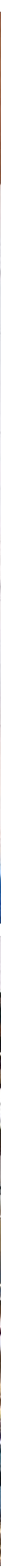

83 | The Journal of Public Space, 3 (2), 2018 | ISSN 2206-9658 
Investing in Spaces: Luxury, Benevolence or Business?
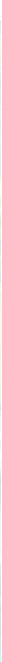

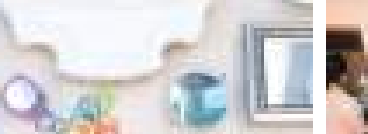

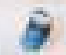

$$
1=
$$
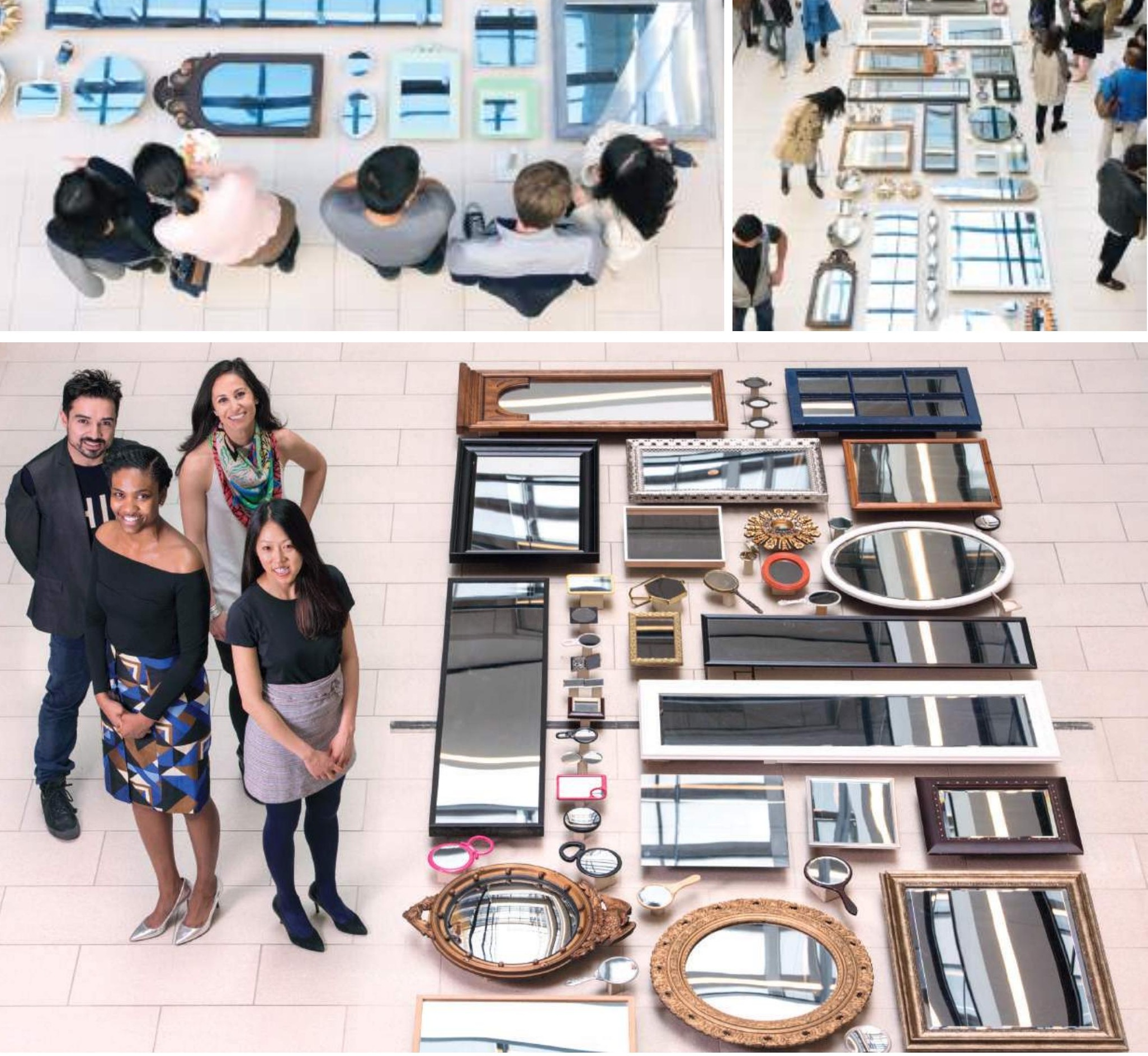

84 | The Journal of Public Space, 3 (2), 2018 | ISSN 2206-9658

City Space Architecture / UN-Habitat 

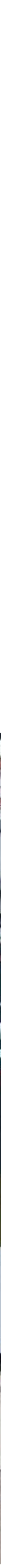

\section{Responsible development in a new} neighborhood

Client: Broder

Artists: Ellen Rutt \& Patrick Ethen

Broder, a LEED Platinum, holistically-minded and sustainability-focused developer, was interested in providing the local community with an art piece during the 18-month construction process for a new residential building in Lincoln Park, Chicago.

The engagement scope included the following guidelines:

- Create something bright, interactive, playful, educational and family-friendly to brighten the $60^{\prime} \times 8^{\prime}$ plywood construction fence

- Build a social atmosphere and community identity

- Create a conversation piece and social buzz drawing people and interest to the neighborhood and project

- Use beauty to build empathy 
Investing in Spaces: Luxury, Benevolence or Business?
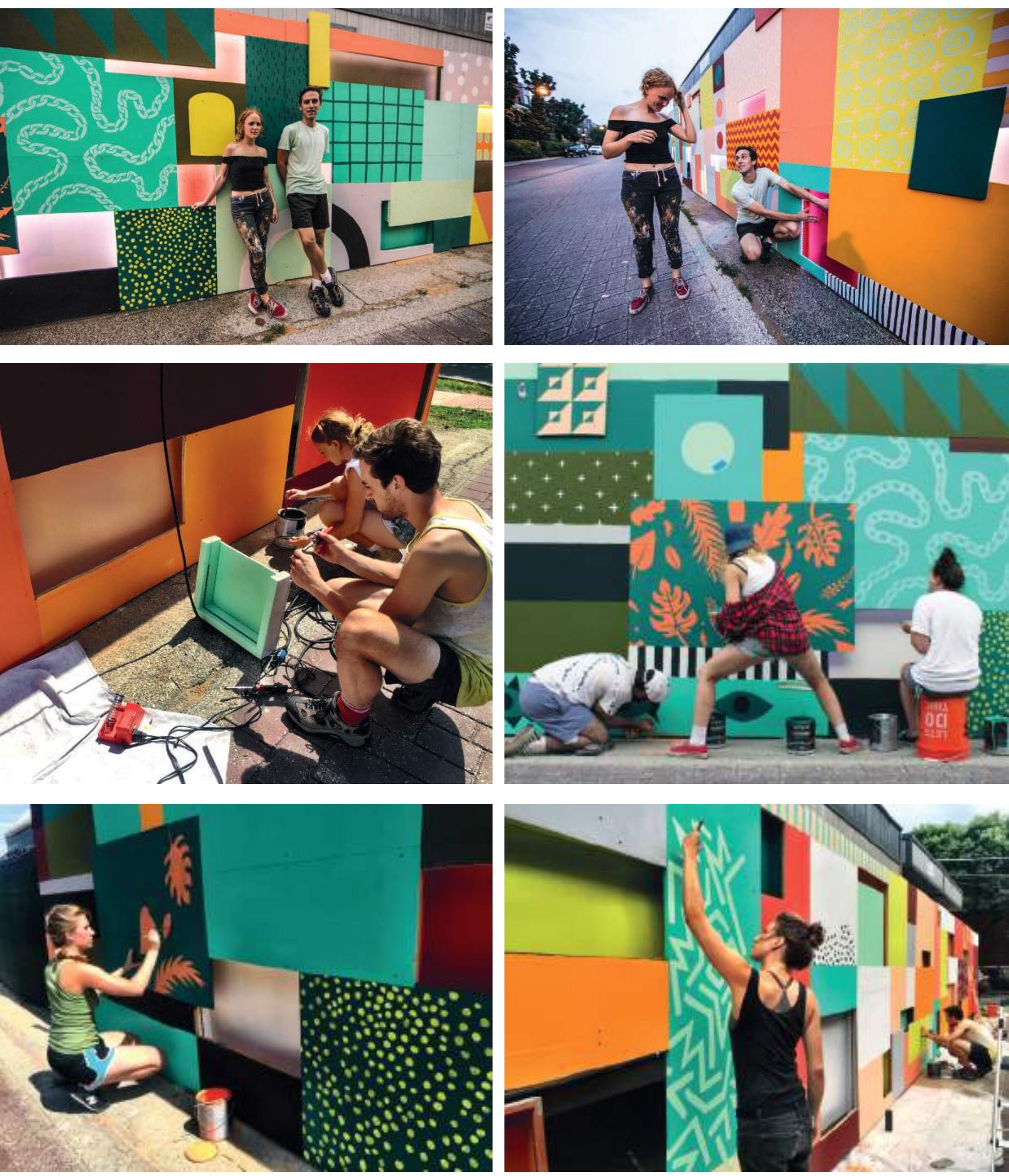

86 | The Journal of Public Space, 3 (2), 2018 | ISSN 2206-9658

City Space Architecture / UN-Habitat 
Investing in Spaces: Luxury, Benevolence or Business?
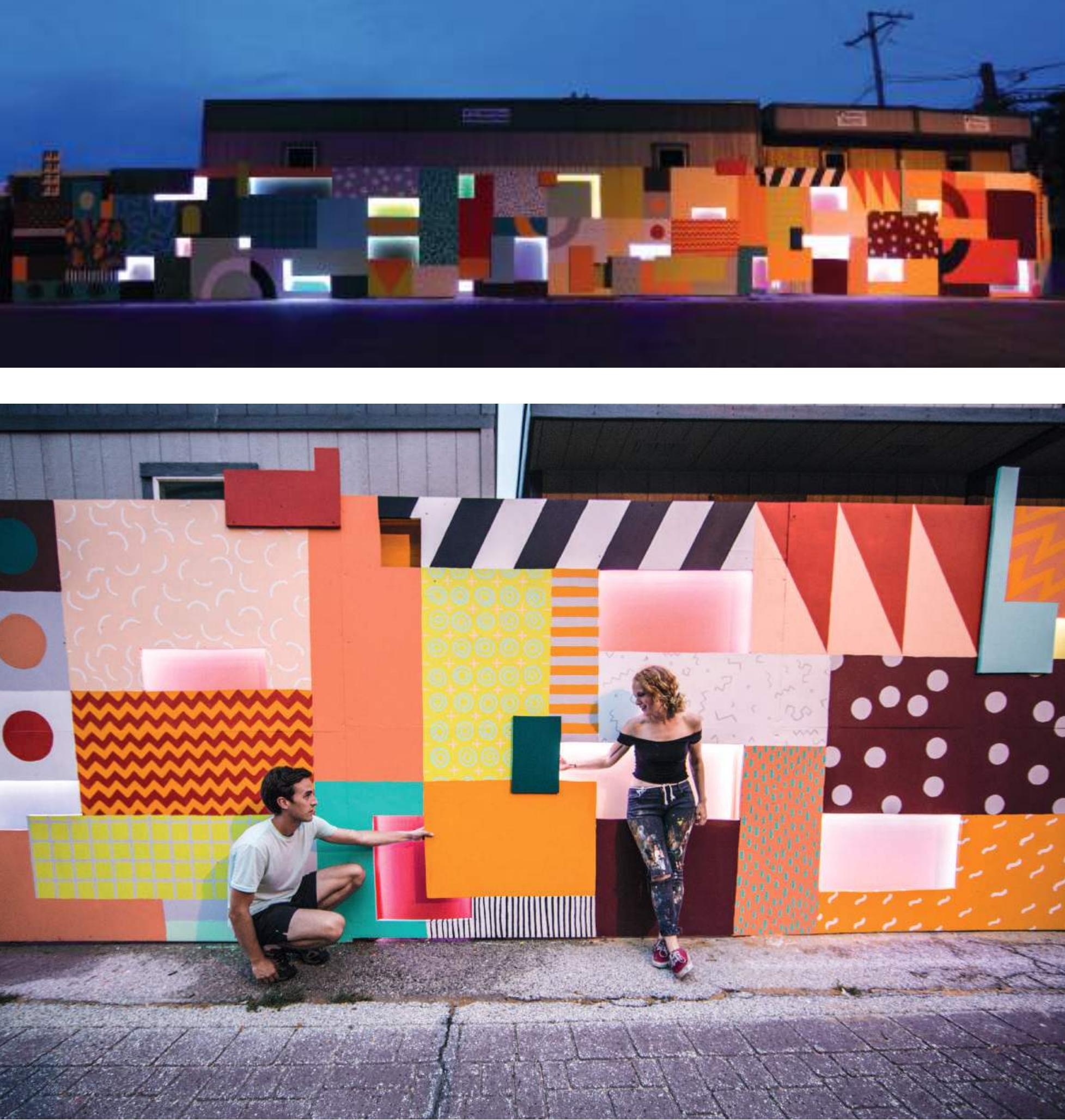

88 | The Journal of Public Space, 3 (2), 2018 | ISSN 2206-9658

City Space Architecture / UN-Habitat 


\section{Integrating and representing a diverse team}

Client:YouTube

Artist: Miguel Arzabe

YouTube was looking for a way to integrate and represent their diverse team. They were interested in creating an opportunity for team members to engage with each other in a creative and authentic way. They were also looking for a way to activate an underutilized common space.

Invesment in diversity isn't just good for the world, it is good for business. Deloitte did a study that showed that teams that have more gender diversity are 15 times more effective, and teams that are ethnically diverse are 35 times more effective.

limeSHIFT was challenged with how to create integration in the workspace. limeSHIFT curated a selection of local artists from San Francisco and the bay area that matched YouTube's brief. The company wanted to collaborate with an artist whose practice embodied inclusivity, collaboration, and positivity. It was also important that the artist have a meaningful trajectory already.

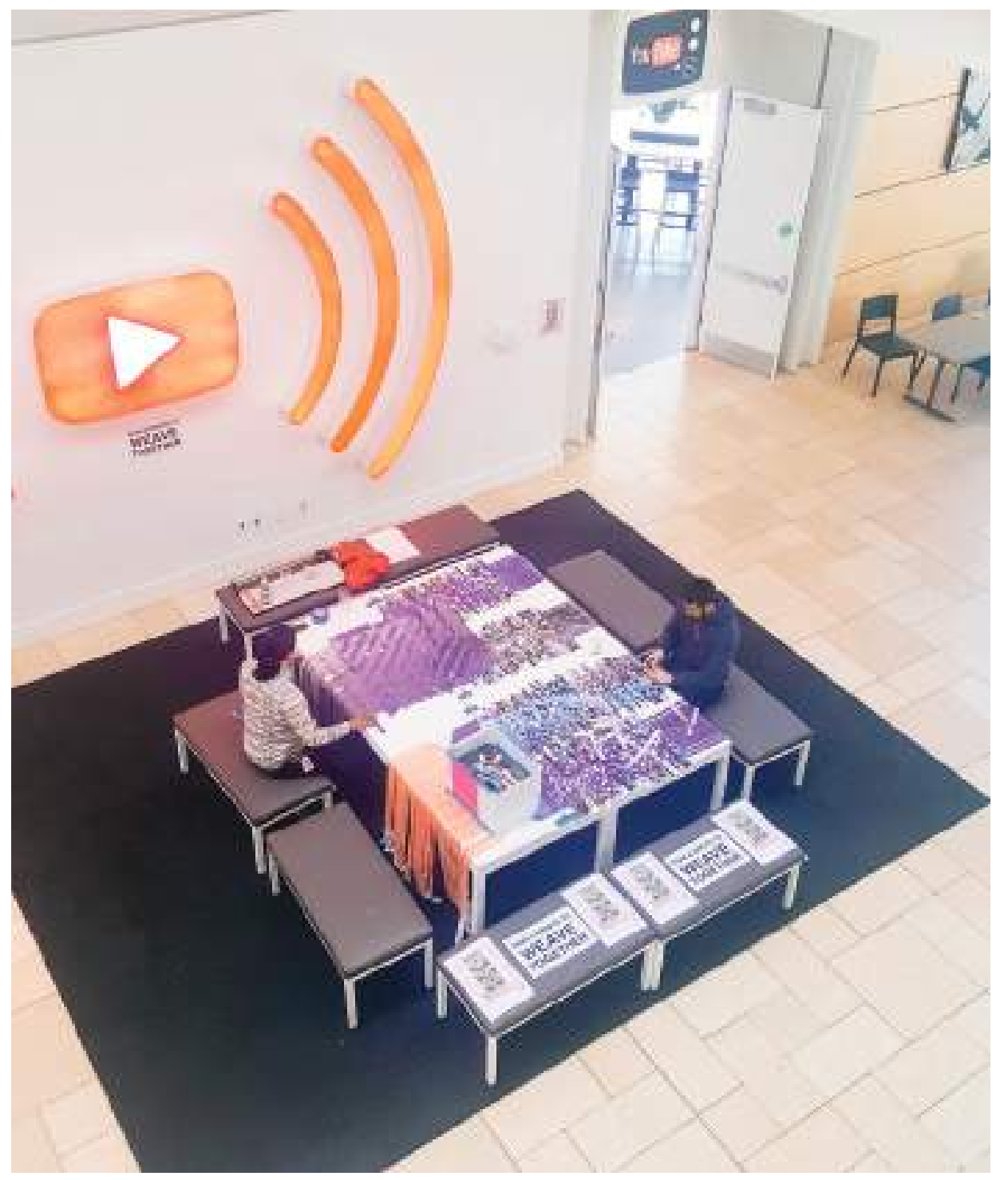

89| The Journal of Public Space, 3 (2), 2018 | ISSN 2206-9658 


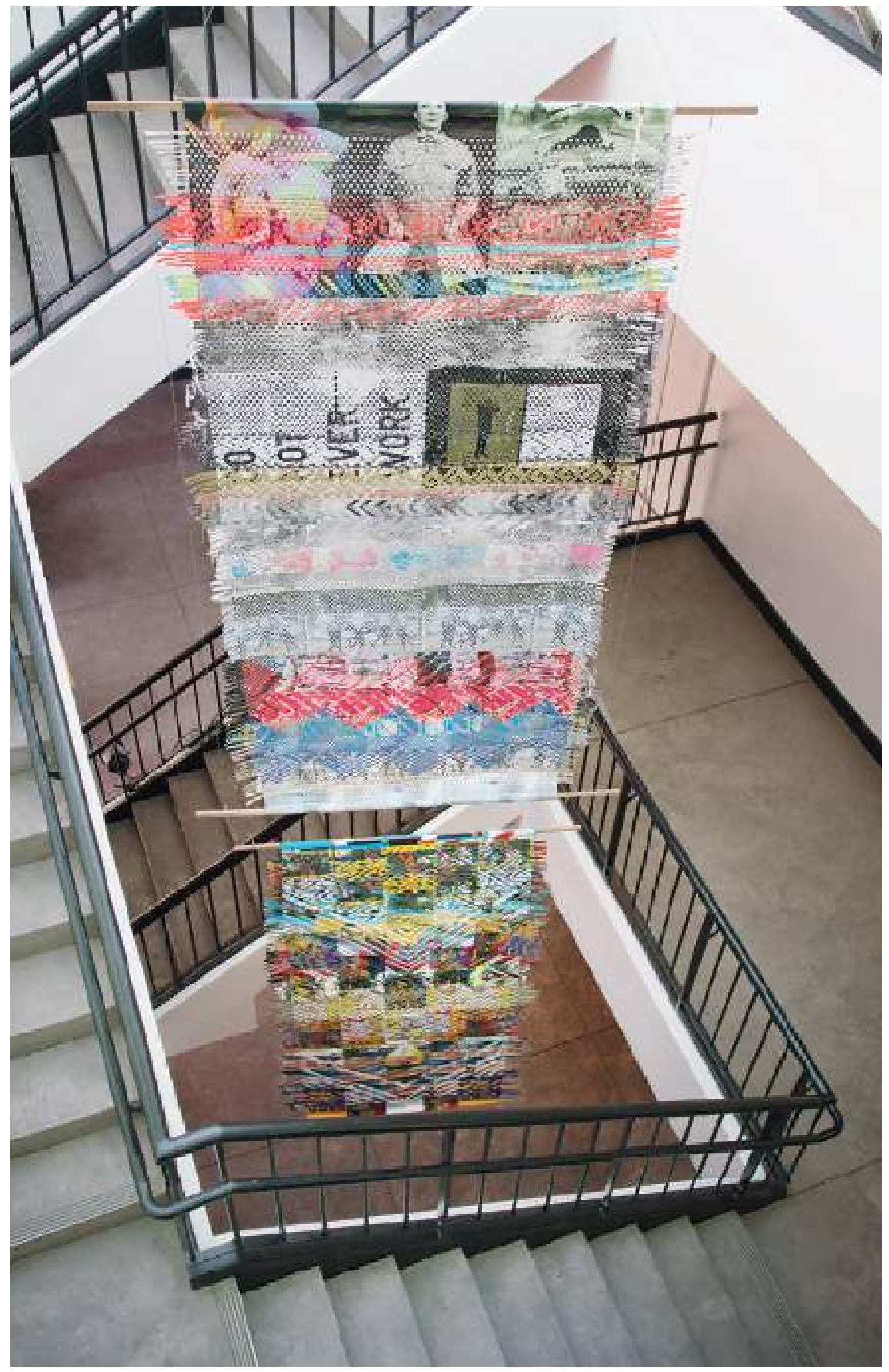

90 | The Journal of Public Space, 3 (2), 2018 | ISSN 2206-9658

City Space Architecture / UN-Habitat 
The selected artist, Miguel Arzabe is a San Francisco-based visual artist who works across media, including painting, video, and paper weaving.

Arzabe's work has been featured in such festivals as Hors Pistes (Centre Pompidou, Paris) and the Festival du Nouveau Cinéma (Montreal); and in museums and galleries including RM Projects (Auckland), FIFI Projects (Mexico City), Marylhurst University (Oregon), and Berkeley Art Museum.

The engagement scope included the following guidelines:

- Create conversations about diversity and inclusion and how team members experience them at YOUTUBE

- Guide a collaborative process where team members physically contribute to the making of the communal weaving

- Create an authentic social environment where team members can relax.

Working with Arzabe, limeSHIFT was able to design a process where the community could engage in two ways: first, members could submit photos online via the prompt: "Share a picture of yourself that makes you smile." These images were then printed.

Second, members could use the allocated common space to work together weaving the images together over a period of a week.

\section{After the week of collaboration one team member shared:}

"Creating this weaving mural with Miguel was a real opportunity to use my time and my hands in a delightfully unusual and dynamic way."

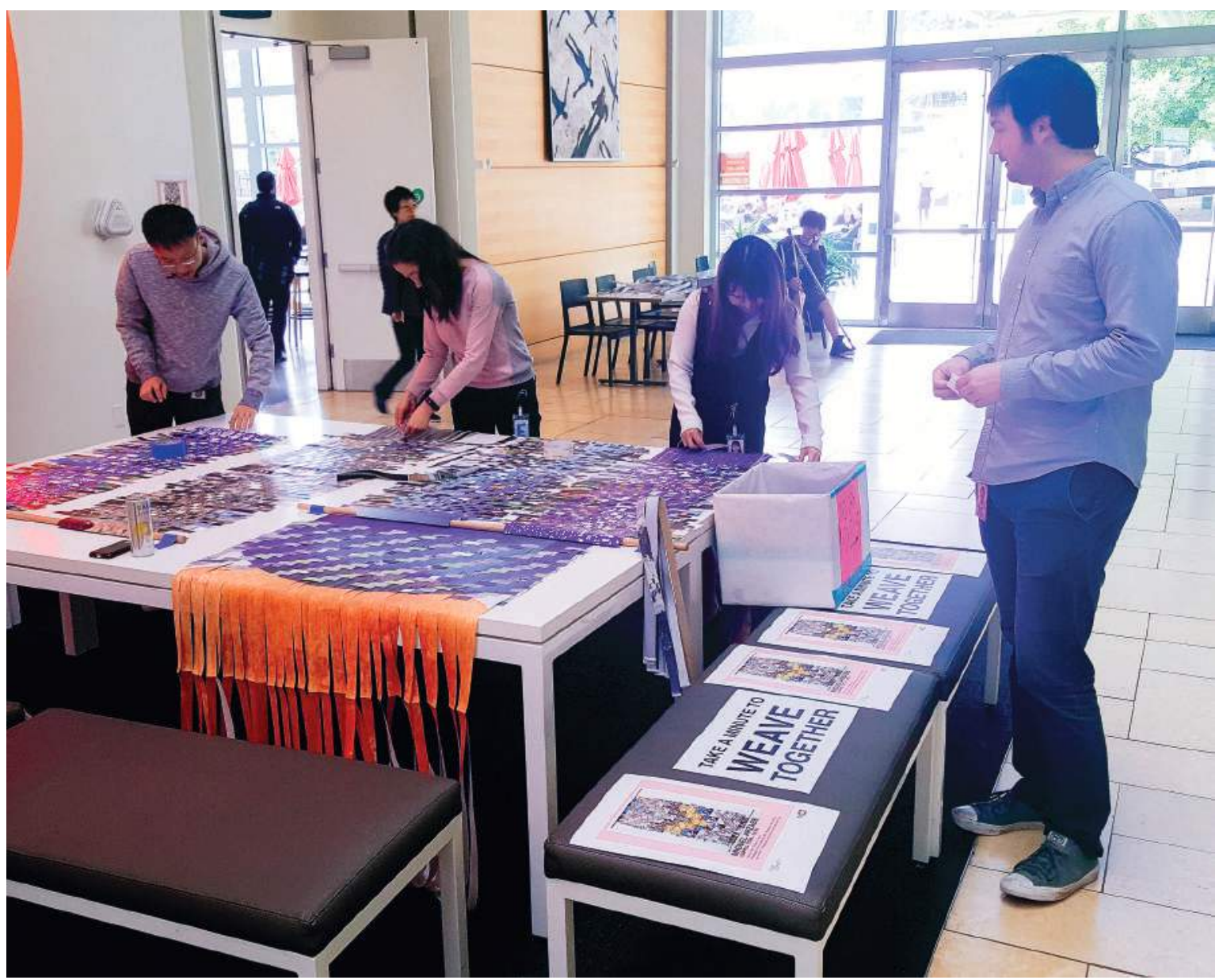

9I | The Journal of Public Space, 3 (2), 2018 | ISSN 2206-9658 City Space Architecture / UN-Habitat 
Investing in Spaces: Luxury, Benevolence or Business?
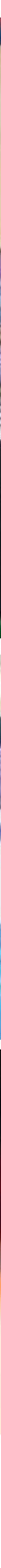

92 | The Journal of Public Space, 3 (2), 2018 | ISSN 2206-9658

City Space Architecture / UN-Habitat 


\section{Colour in Faith}

Client: Public-Private Partnership between a paint company, Sadolin Paints (now Plascon), local Government and civil society organizations (primarily religious, activist or artistic) Artist:Yazmany Arboleda

In 2016, Colour in Faith, a project of inCOMMONS, invited religious communities to paint their sacred spaces in "optimistic yellow." Colour in Faith attempts to reclaim, revive, and reunite communities in Nairobi materially and socially following the series of terrorist attacks and ethnic clashes. Three churches and one mosque were painted in the neighborhood of Kibera, before the project moved to other neighborhoods creating a movement of neighborhoods invested in solidarity.

Colour in Faith project in Kibera is a testimony to reimagine the luxury of benevolence as investment in local expressions and meaning of work, labour, and well-being. In discussing the with pastor Onesmus from the Pentecostal Assemblies of God (PAG) Makina, he expressed the notion of belonging, but also refuge, safety, and acceptance that the symbol of yellow offers to the community. He offers:

"When you see this colour, which means that we are together. So we are together, so in case of anything you can just run, when you are Muslim, when you are Christian, you can just run for safety in that place. So you can see there's a mosque down there, it was painted yellow. There's another church that was also painted yellow". (6 February 2018, Makina, Kibera) Although Onesmus only echoes one perspective, he repeats often that "peace prevails" when people in Kibera feel safe to do the ordinary tasks of the day.

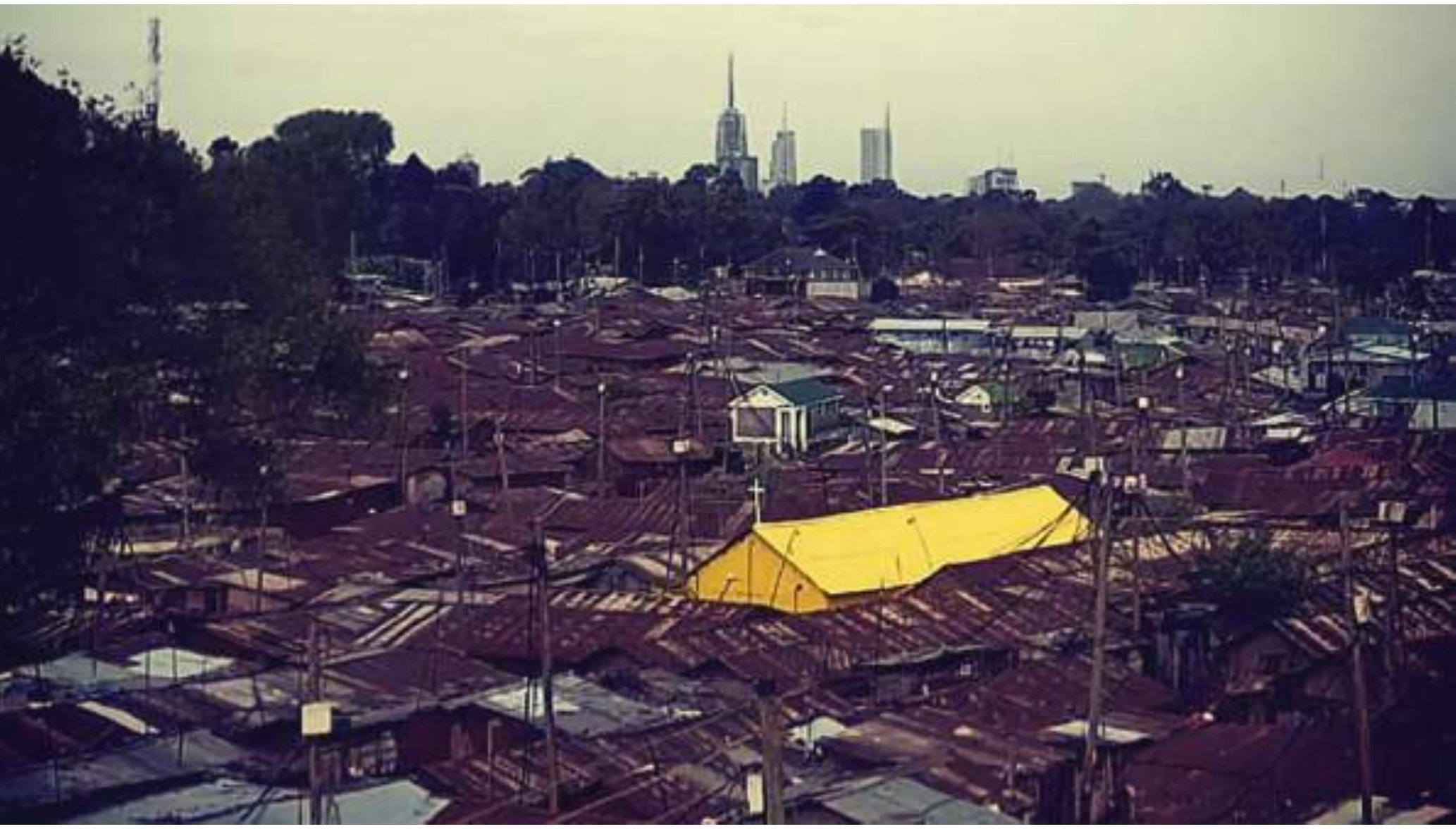

93 | The Journal of Public Space, 3 (2), 2018 | ISSN 2206-9658 City Space Architecture / UN-Habitat 
Investing in Spaces: Luxury, Benevolence or Business?
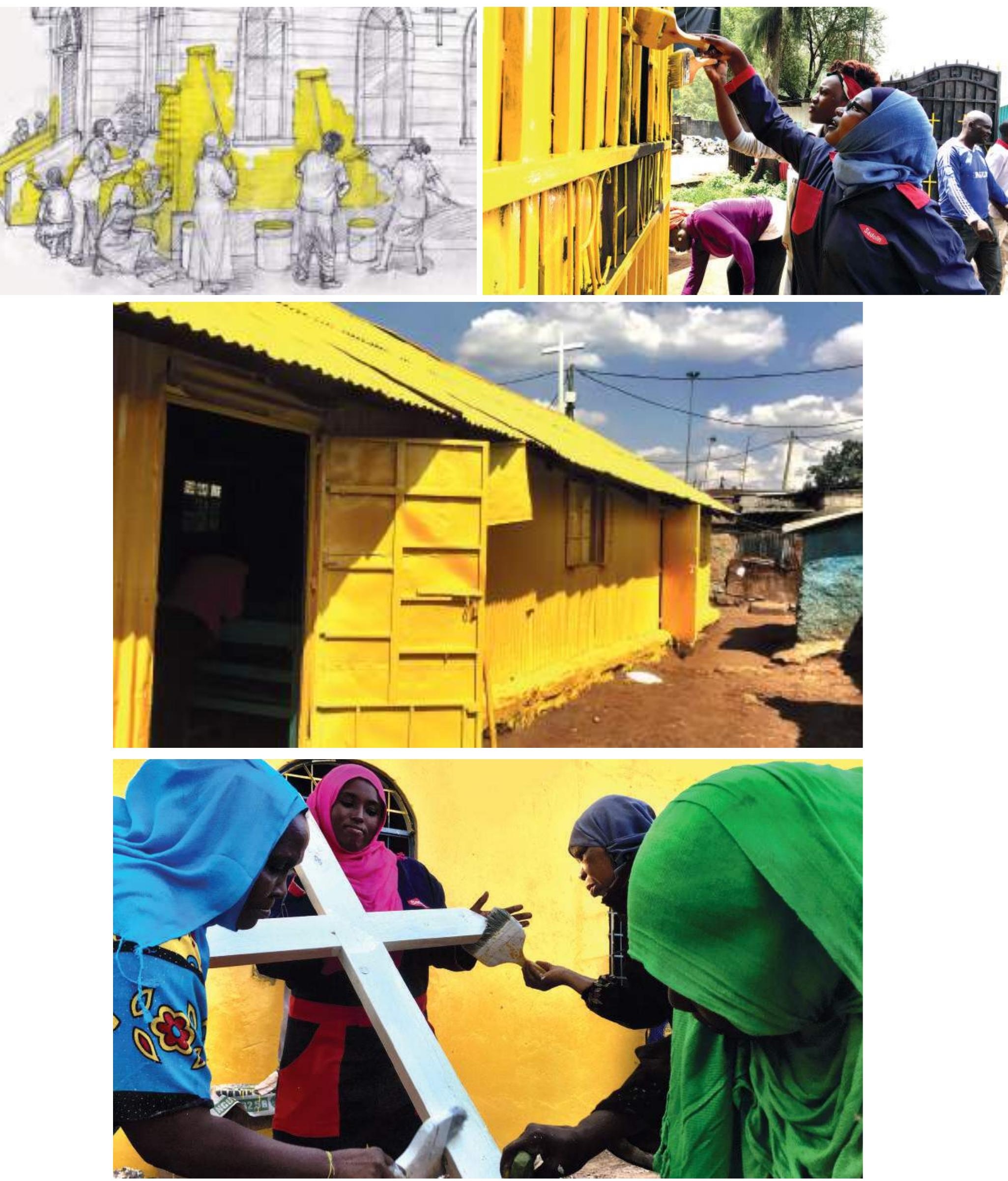

94 | The Journal of Public Space, 3 (2), 2018 | ISSN 2206-9658

City Space Architecture / UN-Habitat 
Investing in Spaces: Luxury, Benevolence or Business?
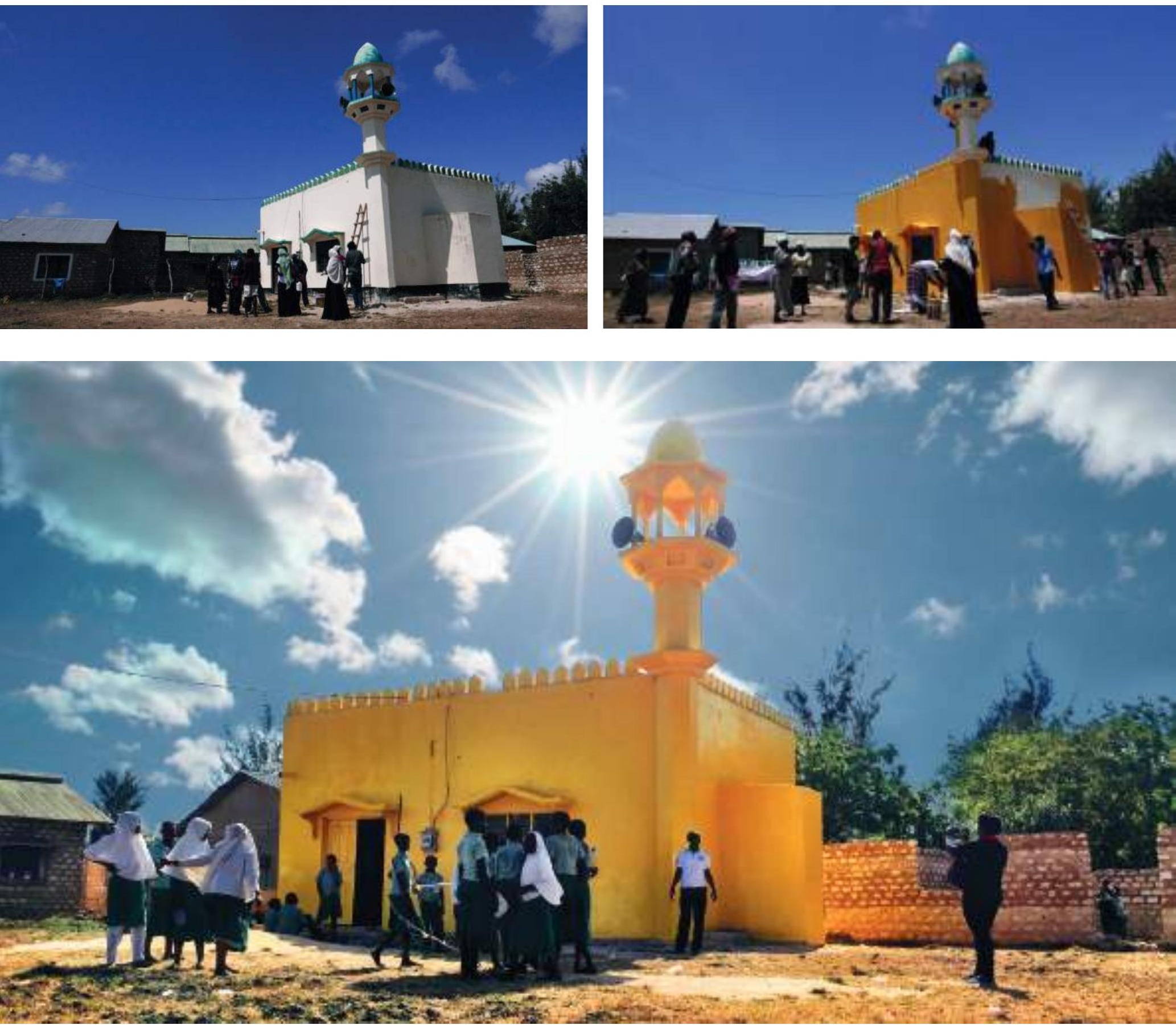

96 | The Journal of Public Space, 3 (2), 2018 | ISSN 2206-9658

City Space Architecture / UN-Habitat 
The Journal of Public Space

ISSN 2206-9658

2018 | Vol. 3 n. 2

https://www.journalpublicspace.org

\title{
From sidewalk ballet to defending the city
}

Maria del Carmen Mota Utanda

Universidad de Castilla-La Mancha, Spain

Carmen.Mota@uclm.es

\begin{abstract}
The city is primarily a public space as it is both a condition and an expression of its citizens. It is the environment where citizens can and should feel as such: free, equal and different. It is where society is performed, where it represents itself and is shown as a community that cohabitates and shows its contradictions, disputes and differences.

The city is where collective memory is created and where all the different identities emerge. For this reason, this is the ideal location for Humanae. The faces of thousands of citizens crowding halls and museums to conquer the squares. From the streets of a marginalized neighborhood in Málaga - Spain, or the Rotary Praça in São Paulo - Brazil, to a building at United Nations Habitat III and the entrance of the World Economic Forum in Davos, Humanae uses public space to involve citizens from all over the planet in a global dialogue.
\end{abstract}

Keywords: city, citizens, difference, identities, art

\section{To cite this article:}

Mota Utanda, M. (20/8). From sidewalk ballet to defending the city. The Journal of Public Space, 3(2), 97-I I4, DOI 10.3289 I/jps.v3i2. I I I I

This article has been accepted for publication in The Journal of Public Space. Please see the Editorial Policies under the 'About' section of the journal website for further information.

(c) (4) (8) This work is licensed under a Creative Commons Attribution - Non Commercial 4.0 International License https://creativecommons.org/licenses/by-nc/4.0/ 
"When I get home after work, the ballet is reaching its crescendo. This is the time of roller skates and stilts and tricycles, and games in the lee of the stoop with bottletops and plastic cowboys; this is the time of bundles and packages, zigzagging from the drug store to the fruit stand and back over to the butcher's; this is the time when teen-agers, all dressed up, are pausing to ask if their slips show or their collars look right; this is the time when beautiful girls get out of MG's;

this is the time when fire engines go through; this is the time when anybody you know around Hudson Street will go by."

This is Jane Jacob's famous "sidewalk ballet"; a dance that never repeats itself from place to place because its merging-of styles, buildings, functions and, of course, citizens-does not represent chaos, as argued by modern urbanism theory, but rather a complex and highly developed form of order. The journalist, urbanist and socio-political activist, whose centenary was recently celebrated the world over, defended the value of bringing together distinctive elements to create, not a dance of exactness and uniformity, but rather an intricate ballet whose defining characteristics are clearly illustrated by each of its parts, coming together to create one wonderful, harmonious and orderly whole. A young boy speeding past on his tricycle with his curly hair blowing in the breeze, with what we could call a café-au-lait complexion; a teenager with a more hazelnut-brown skin colour; a firefighter perched on top of his engine with a remarkable skin tone resembling strawberry bubble gum. A real mishmash. Or perhaps not. Because beneath the seeming disorder of the diverse city lies a marvellous order that cannot be achieved by attempts at homogenisation.

Jacobs, author of "The Death and Life of Great American Cities", which was described by the New York Times as perhaps the most influential work in the history of city planning, managed to save NYC's Washington Square Park from its fate as a highway intersection and preserve the area for pedestrians. Her book advocates diversity, not as a reality, but as the best version of such reality.

\section{The Venice Biennale and the Freespace manifesto}

In the same vein, it is no surprise that the most high-profile events in the urban planning calendar, such as the Venice Biennale or the European Prize for Urban Public Space, evaluate civic initiatives aimed at strengthening the city's function as a public space and a place of encounter. This explains the commitment to a philosophy of the creative process that is based on the meeting of words and ideas. The main objective of these events is to achieve a type of architecture that combines its artistic dimension with a mission to meet human, material and symbolic needs.

Within this context, in June 2017 the Freespace manifesto was published. It is a reference point for all those participating in the Venice Biennale, an exhibition of a truly mammoth scale, leading to an understanding of the city as a product of history and culture, as opposed to an entity or an evolving natural object. This is because, as already defended by Ortega y Gasset, the essence of a city is not its nature, which man changes at whim to adapt it to his needs, but rather its history, the marks left behind by its contingencies. Discovering cohesion amid diversity and chaos. This is one of the ideas of the manifesto, where the use of dance as a metaphor, over fifty years after Jacob's work was released, appears to be no accident: 
"We are interested in going beyond the visual, emphasizing the role of architecture in the choreography of daily life. . . We see the earth as Client. This brings with it long-lasting responsibilities. Architecture is the play of light, sun, shade, moon, air, wind, gravity in ways that reveal the mysteries of the world. All of these resources are free. . .

We believe these qualities sustain the fundamental capacity of architecture to nurture and support meaningful contact between people and place. We focus our attention on these qualities because we consider that intrinsic to them are optimism and continuity.

Architecture that embodies these qualities and does so with generosity and a desire for exchange is what we call Freespace."

Just before reaching its conclusion, the manifesto invites all participants to bring their Freespace to Venice, so that together we can discover the diversity, particularity and continuity of a kind of architecture that is based on people, place, history and time, in order to support culture and the importance of architecture on our dynamic planet. People, place, time, history... we've almost arrived to Humanae.

\section{Humanae: Work in Progress. The planning behind the project}

Angélica Dass' Humanae: Work in Progress is conceived as a tool for exploring, questioning and searching for identity, both one's own and that of others, using photography to set up a dialogue. A game whereby social and personal codes are proposed for reinvention; a constant circular flow between the photographer and the photographed; a bridge between masks and identities.

The project champions diversity; however, it manages to do so in a new way, presenting images of real people, minus any airbrushing, which show their naturalness in its purest state. The project has received coverage in the media- appearing in a TED Talk and on the cover of Foreign Affairs- and has been made available in the urban space, being featured in museums all over the world. Dass's work is being used as a genetic research tool for Milan's Leonardo da Vinci National Science and Technology museum in its genetics section and as a school project in countless primary schools for studying the topic of diversity. The formats are nearly as varied as the colours of the portraits, with one purpose as an objective: encourage the viewer to recognise and embrace differences for what they are: a good thing that makes each one of us unique and special.

This creative concept is paired with a rigorous and systematic process: each photo is set against a background that matches the colour of an II-by-II-pixel sample taken from the model's face. Lined up just like in a colour sample book, horizontality is not only a formal feature: it also has an ethical dimension. In this way, with extraordinary simplicity, the false supremacy of certain races over others fades away; it is enough to "innocently" move the issue of race out of the socio-political context into an innocuous environment, that of a colour chart, where the primary colours are just as important as the blended colours.

However, the idea of "work in progress" is not random; it is a potentially never-ending project aimed at doing away with the colour codes associated with race, while inviting a reflection on equality that goes on to subtly become a plea for diversity, which its creator has experienced first-hand. Dass's multiracial background, typical in Brazil, means that her body comprises many colours: "I have indigenous, African and Portuguese blood. I always saw all of these colours represented within me and, although they were different, they 
were treated the same. I try to bring this idea of equality that I learnt in my multicolour family into the world".

Unlike most photo projects, viewed only at exclusive events held by the circles in which they are created, since its inception Humanae has had a vocation to be open to the world and thanks to its critical and thought-provoking content, ended up, quite naturally, transcending the boundaries of photography. The fact that a selection of Humanae portraits once appeared on the front of the building hosting the 2017 Davos World Economic Forum is a clear testament to this.

\section{Defending the city, public life and difference}

Humanae, in its multiple versions, takes the city by storm. And it does so from the understanding that the city is not just a place; its value is not based solely on its buildings and scenery, but can be found in the people who inhabit it. Dass photographs a huge number of local people who stand up for, by appearing in the portraits, the beauty of the natural.

Dass, Jacobs and the Freespace manifesto are defenders of communal life; they contend that therein lies the solution to so many contemporary issues. Getting to know your neighbours, forming networks, mixing with different people, greeting each other and being able to laugh again, we can do all of these things in the public space, the authentic and complex social institution where from childhood we learn to socialise and build communities.

Humanae is boundary-breaking on many fronts: by getting featured in museums from all the world, it leaves behind the more traditional territory of photography and takes to the streets, which for Dass means that, beforehand, one should have a deep understanding of the city and the public space in question, and know where to find its spirit, how residents use it, what they like about it, what activities they perform in its streets. Only then can the right dimensions, the appropriate layout and the ideal perspective be achieved. Essentially, a prior understanding of the place is required, which is why we have to walk around the city, talk to its people, see how it fosters the wonderful interweaving of relationships, links and encounters between its inhabitants. Ultimately, Humanae favours the public space as the best catalyst for achieving its objectives; it manages to elevate its status to being at the very heart of modern life. It compels prior understanding to trigger action, from a place of utmost respect. It humanises the public space and promotes the experience of contact, exchange and difference, through portraits of the people that bring life to it. No labels and no standardisation, as this is the way to improve, not only our cities, but our world.

\section{The city and the championing of diversity: work in progress}

Building a positive discourse around diversity by involving a growing number of people is an endeavour that is destined to go on indefinitely, just like the battle for the best kind of city. A never-ending journey lies ahead for this project which brings together artistic, anthropological, sociological and sentimental values. Just like the city itself, just as our own experience shows us, to quote Borges "We are our memory, we are that chimerical museum of shifting shapes". Our memory, what we are and what we come from, makes every cell in our body unique, and by cell, we also mean pixel. 


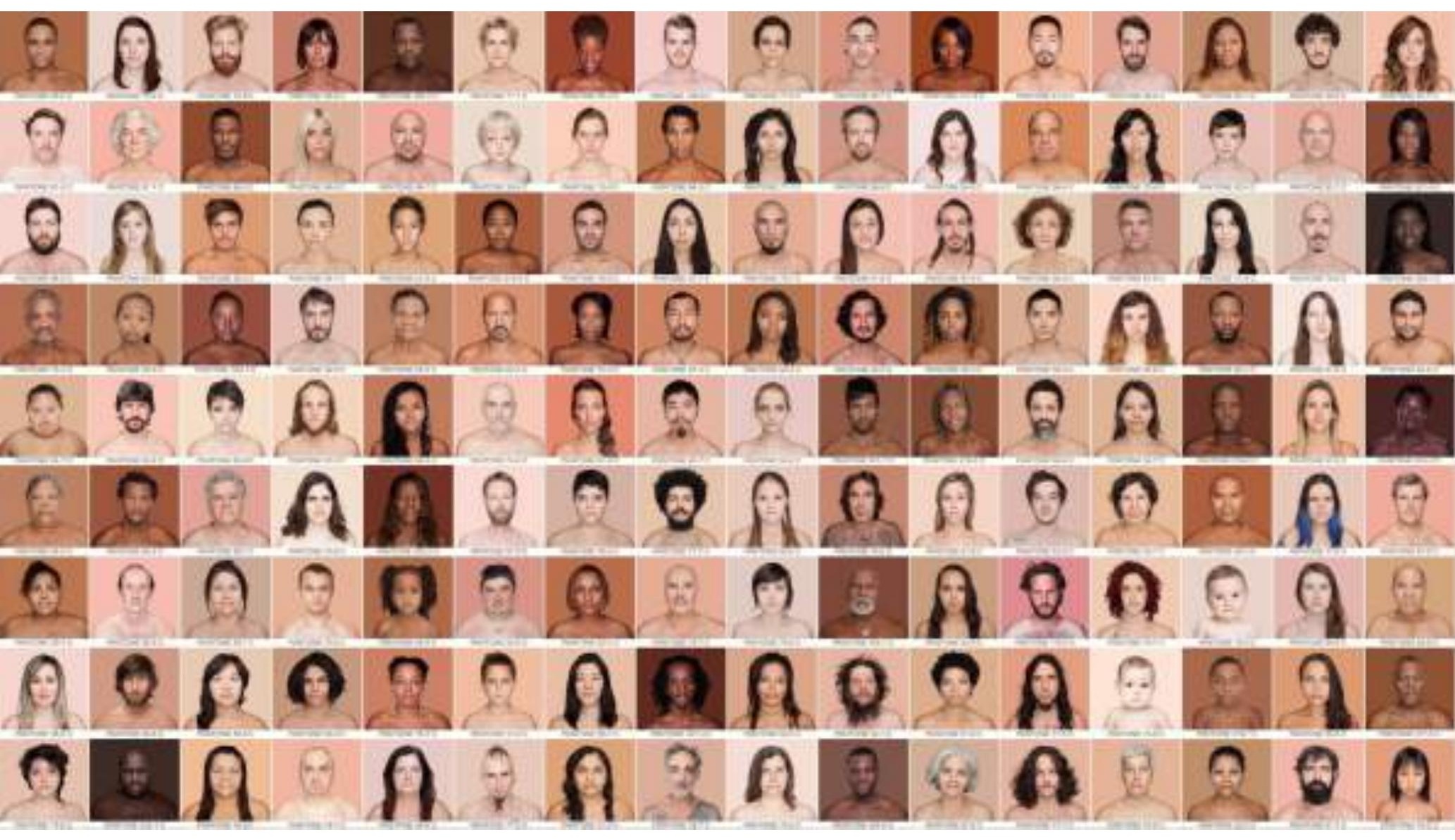

Humanæ is a photographic work in progress by artist Angélica Dass, an unusually direct reflection on the color of the skin, attempting to document humanity's true colors rather than the untrue labels "white", "red", "black" and "yellow" associated with race. It's a project in constant evolution seeking to demonstrate that what defines the human being is its inescapably uniqueness and, therefore, its diversity. The background for each portrait is tinted with a color tone identical to a sample of II x II pixels taken from the nose of the subject and matched with the industrial pallet Pantone $®$, which, in its neutrality, calls into question the contradictions and stereotypes related to the race issue. More than just faces and colors in the project, there are almost 4,000 volunteers, with portraits made in 26 different countries and 28 different cities around the world, thanks to the support of cultural institutions, political subjects, governmental organizations and non-governmental organizations. The direct and personal dialogue with the public and the absolute spontaneity of participation are fundamental values of the project and connote it with a strong vein of activism. The project does not select participants and there is no date set for its completion. From someone included in the Forbes list, to refugees who crossed the Mediterranean Sea by boat, or students both in Switzerland and the favelas in Rio de Janeiro. At the UNESCO Headquarters, or at a shelter. All kinds of beliefs, gender identities or physical impairments, a newborn or terminally ill, all together build Humanae. All of us, without labels. www.humanaeproject.org

Humanae Video - https://vimeo.com/2802217/3 


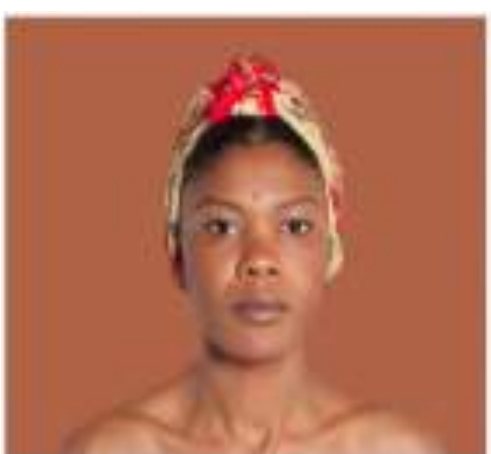

PANTONE $7522 \mathrm{C}$

1979, Rio de Janeiro, Brazil. Lives and works in Madrid.

Angélica Dass is an award-winning photographer living in Madrid, Spain. Originally from Rio de Janeiro, Brasil, she is acutely aware of how small differences in skin tone can swell into large misconceptions and stereotypes about race. She is the creator of the internationally acclaimed Humanæ Project, a collection of portraits that reveal the diverse beauty of human colors. The initiative has traveled to more than 30 countries across six continents - from The World Economic Forum in Davos to the pages of National Geographic - to promote dialogue that challenges how we think about skin color and ethnic identity.

In 2016, her career launches to new dimensions with her TED Global Talk, confirming the great potential of her work to go beyond photography, becoming a tool for social change, which promotes dialogue and challenges cultural prejudices. Today, this TED talk exceeds two million views. As part of the TED Residency 2018, she presents her new talk which will be seen online in October 2018.

Angélica's work transcends the museums and finds in school classrooms a great universe of work. She amplifies the educational message of Humanae through institutional collaborations around the world, such as collaborations with city councils of different cities in the Basque Country, teacher training schools in Madrid, highschools in the Czech Republic, or with UNESCO and the Government of Chile, reaching an impact of more than 50 thousand students in a week. She is also a powerful and inspiring speaker who has lectured at important organizations, such as the University of Salamanca, the University of Bologna, or the UERJ - Rio de Janeiro; as well as the International Congress of Fundraising - The Resource Alliance, at National Geographic and at the World Economic Forum, as a cultural leader.

This career path leads Angélica to fund the Humanae Institute, a non-profit educational platform with the objective to position diversity as a value in the educational process.

http://www.angelicadass.com/humanae/

TED Talk 2016

https://www.ted.com/talks/angelica_dass_the_beauty_of_human_skin_in_every_color?nolanguage 


\section{World Economic Forum, Promenade Entrance}

Davos, Switzerland

January 2017

Humanae was exhibited with a large-scale outdoor installation intended to remind participants of the diversity of the human condition and to inspire more responsive and responsible leadership.

The World Economic Forum partners with international cultural and scientific organizations to engage world leaders on how to empower young people and enable their creativity to meet the challenges of the Fourth Industrial Revolution'.

In January 2017, Dass became the first visual artist to be featured at the World Economic Forum Annual Meeting's promenade entrance, a fact that highlights the impact of Humanae's outdoors exhibits.

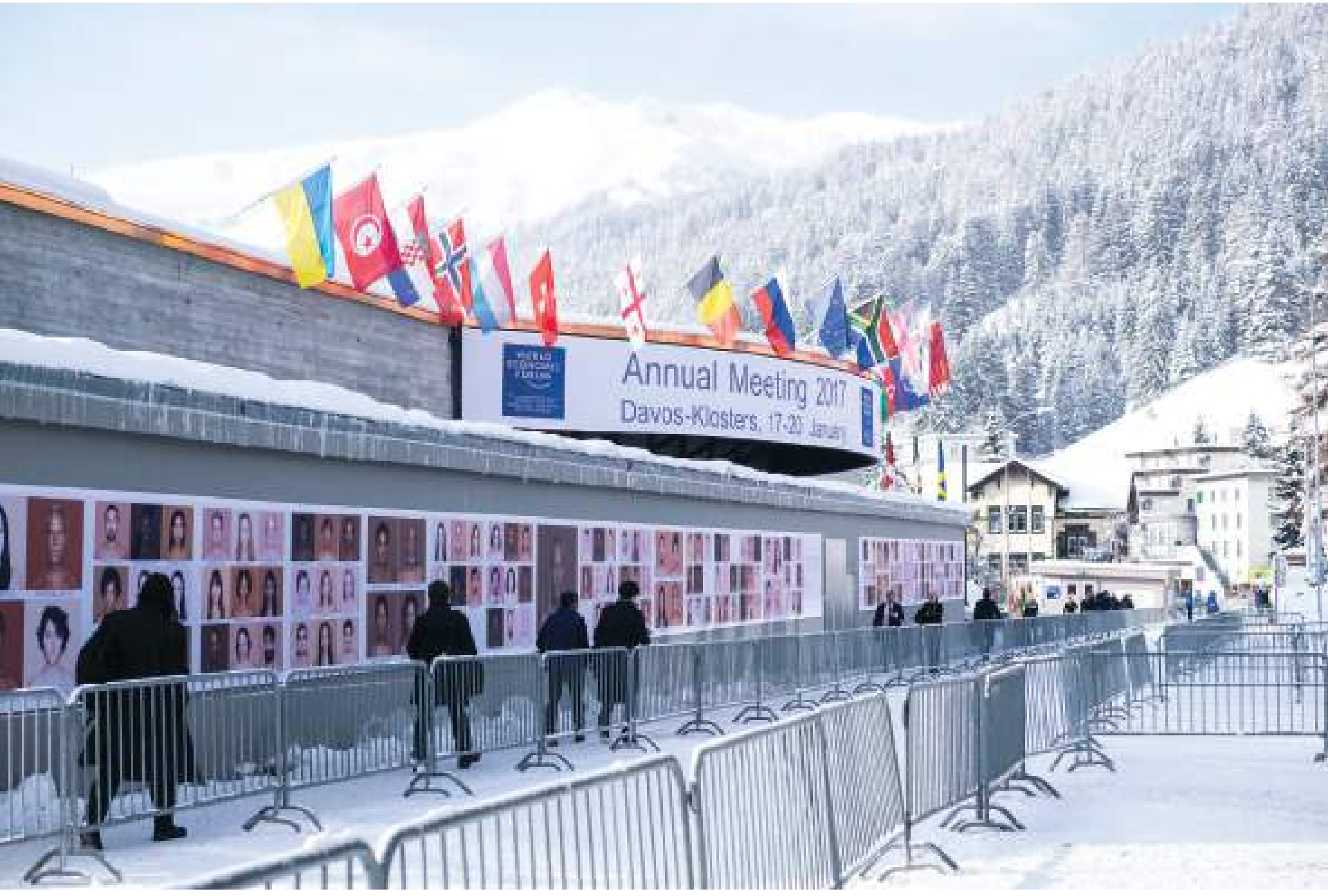

I. https://www.weforum.org/agenda/2016/0I/the-fourth-industrial-revolution-what-it-means-and-how-to-respond 


\title{
Biennale dell'Immagine
}

\author{
Chiasso, Switzerland
}

October 2017

Since 2004, the participation of Chiasso_Culture in movement at the Biennale dell'Immagine is characterized by the promotion of site-specific artistic projects, designed and realized to directly involve the citizens of Chiasso and to publicly discuss issues of great social importance.

For the tenth edition, the Hispano-Brazilian artist Angélica Dass was invited to Chiasso. The experience of Humanæ in Chiasso was developed over an extended period of time and was articulated in a series of complementary activities, according to a practice common to many public art works in which the aesthetic, the relational and the educational and didactic aspects constitute equal and fundamental elements of the work. The project was implemented through three main stages: the Week Against Racism (with the activation of a temporary photographic studio, children's workshop and a public lecture); the School Workshop Series (a series of laboratories on the perception of skin color, with the involvement of almost 100 students of primary and secondary schools in Chiasso); and the Outdoors Installation during the Biennale dell'Immagine (presenting the portraits made in Chiasso, together with others from the Humanæ archive) and and Indoors Exhibition at the Workshop Space (presenting the results of the children's workshops). The three stages compound a unique Humanae Experience where all activities became a place of meeting, knowledge and dialogue.

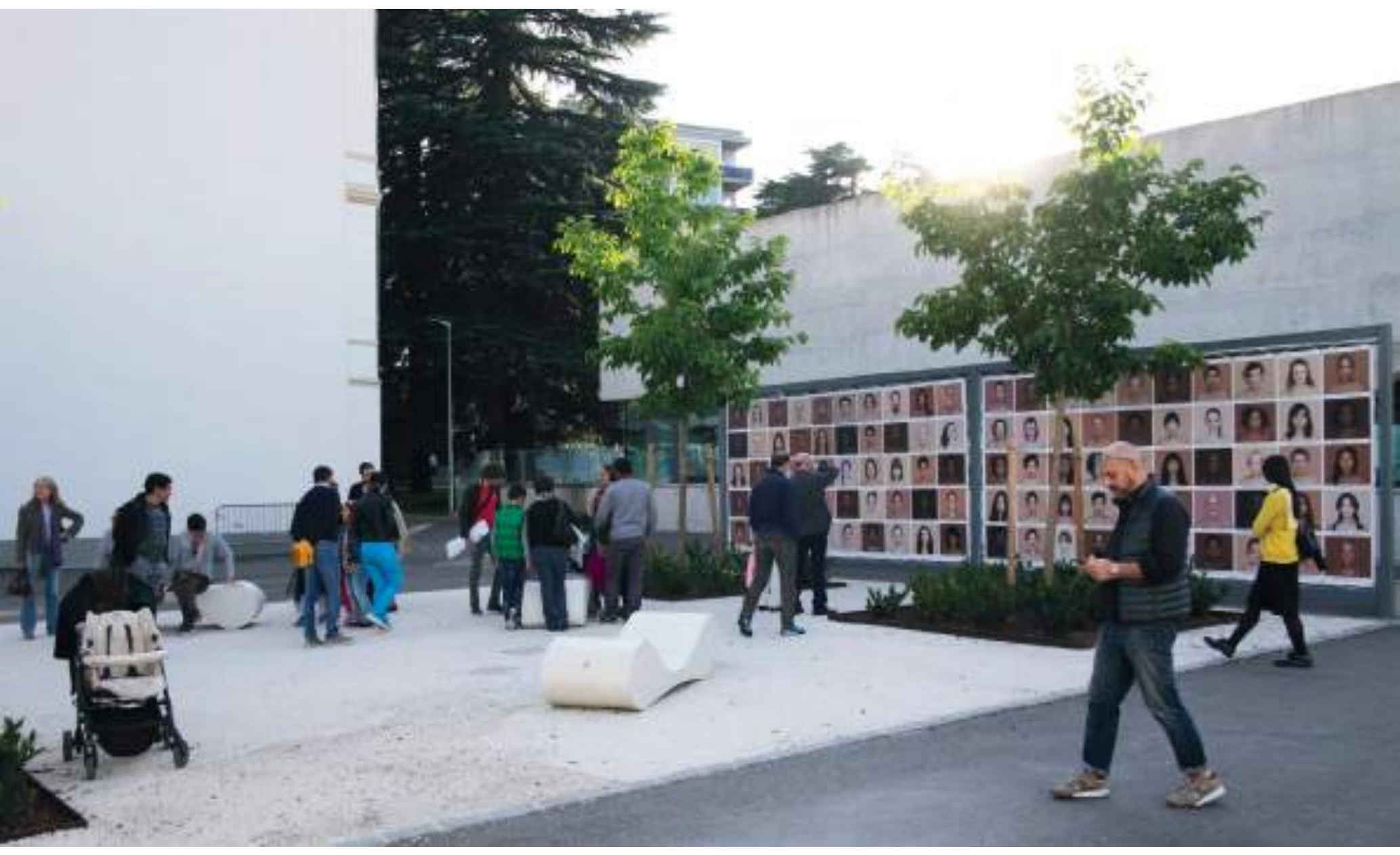

104 | The Journal of Public Space, 3 (2), 2018 | ISSN 2206-9658

City Space Architecture / UN-Habitat 

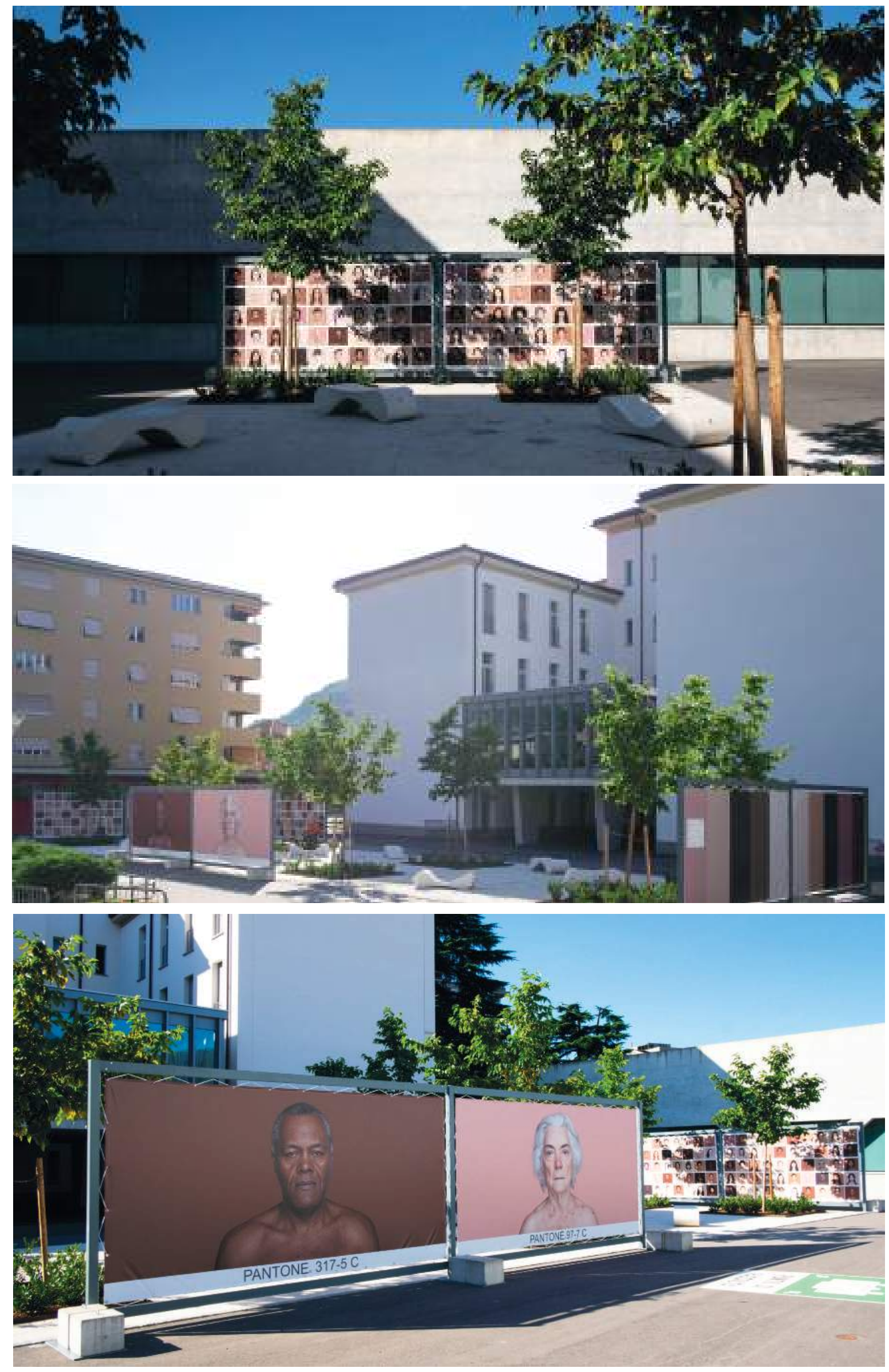

I05 | The Journal of Public Space, 3 (2), 2018 | ISSN 2206-9658 City Space Architecture / UN-Habitat 


\section{United Nations' Habitat III Conference, Arbolito Park}

Quito, Ecuador

October 2016

In Habitat III, the United Nations Conference on Housing and Sustainable Urban Development, at the Quito pavilion, Humanae's most prominent exhibition was presented with a projection of 160,000 lumens in a $12 \times 12$ meter cube. Each of the 64 portraits measured around 3 meters. According to the UN, the conference took place "to revitalize the global commitment to sustainable urbanization, to focus on the implementation of a 'New Urban Agenda', where diversity is a fundamental issue".
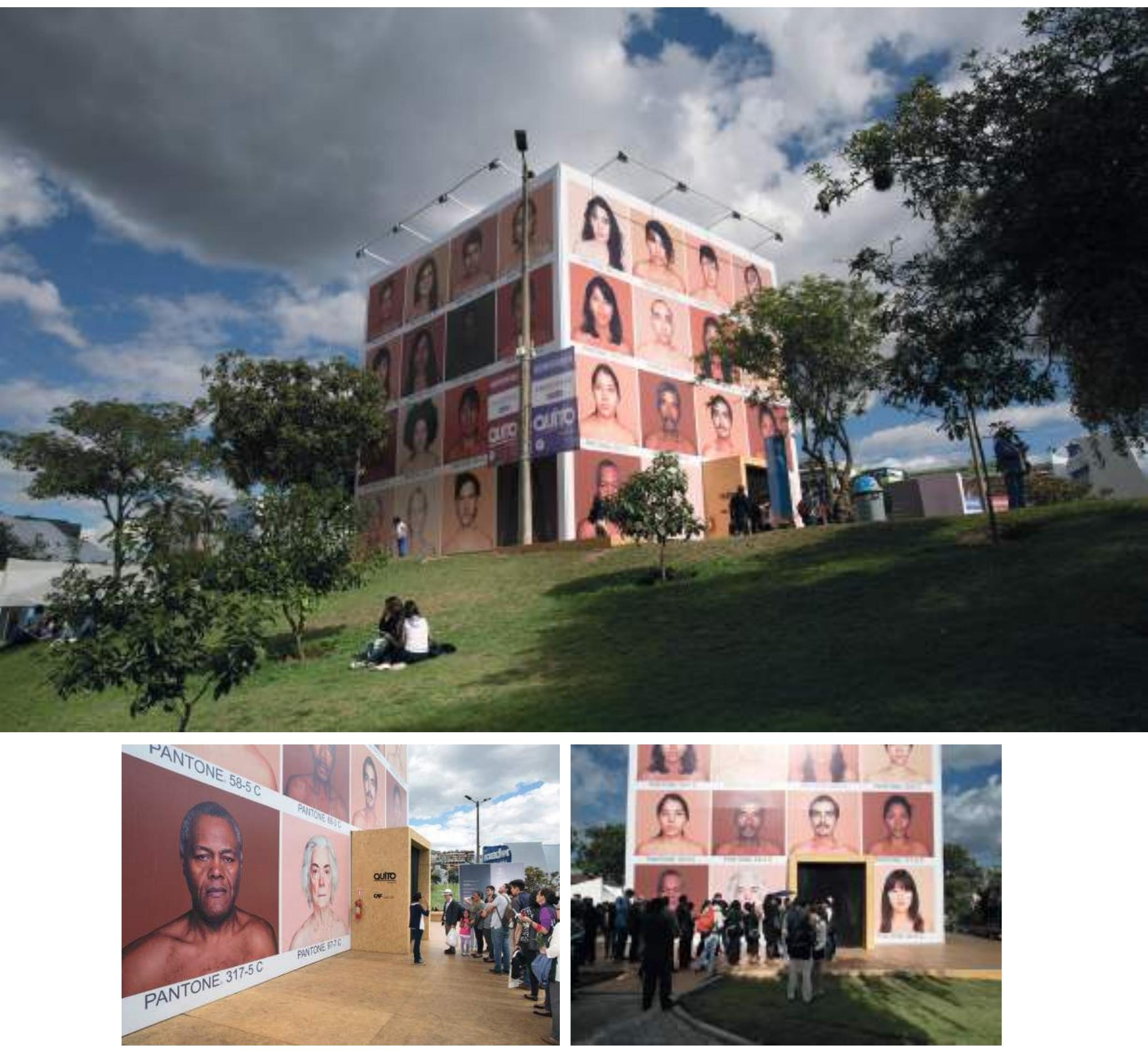

106 | The Journal of Public Space, 3 (2), 2018 | ISSN 2206-9658

City Space Architecture / UN-Habitat 

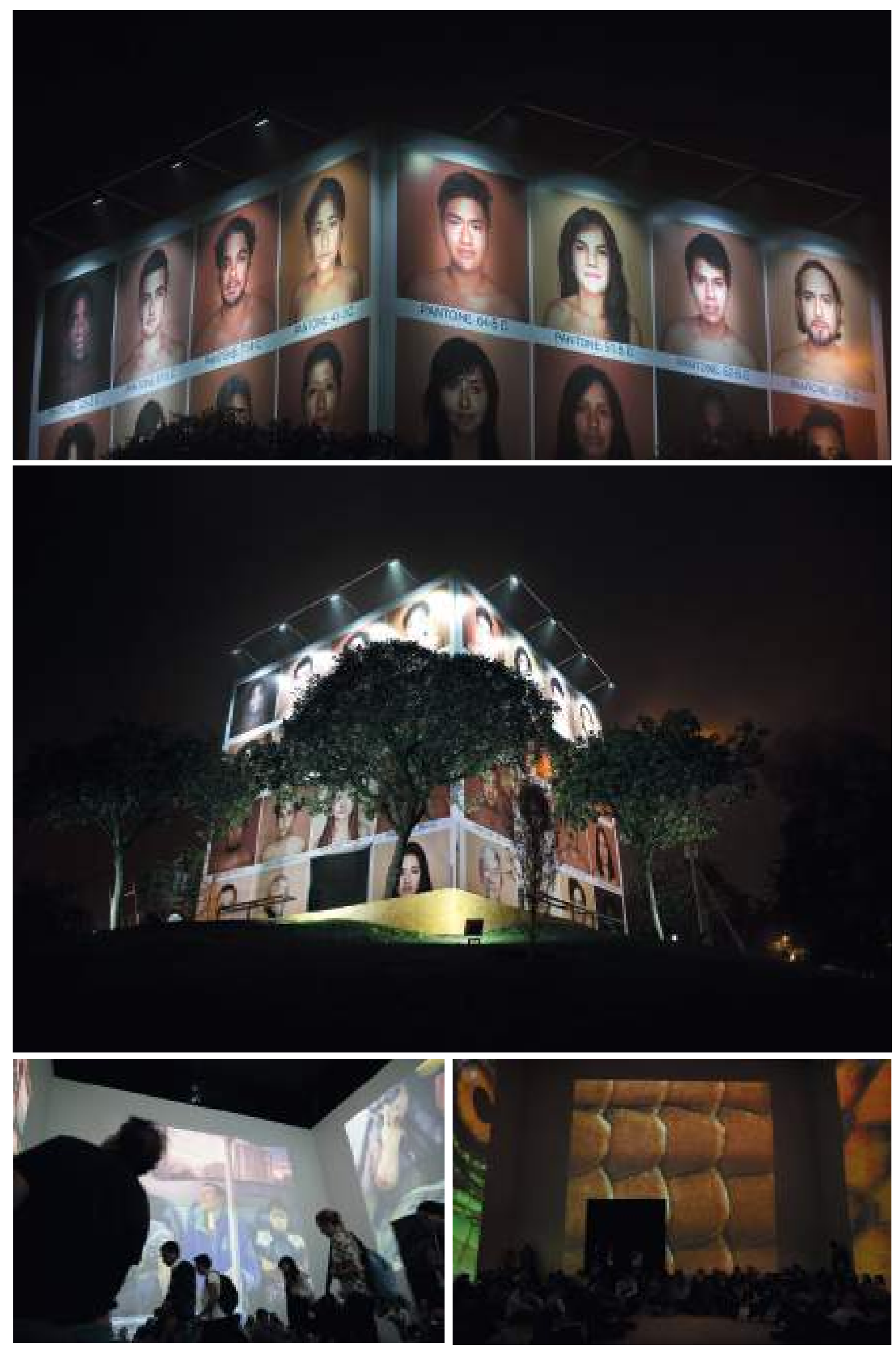

All pictures for the UN Habitat III Conference Humanae installation are from Edu León.

107 | The Journal of Public Space, 3 (2), 2018 | ISSN 2206-9658 City Space Architecture / UN-Habitat 


\section{Paseo Uribitarte}

Bilbao, Spain

March 2016

Commemorating the International Day Against Racial Discrimination (March 2 Ist), Humanae was invited to the cities of Bilbao. For this public installation, Dass collaborated with the City Council of Bilbao, and made an open call for citizens to volunteer and neighbors. The selected images formed a mosaic of local faces, together with others from the Humanæ world archive, exhibited in six large cubes bordering a pedestrian area of Paseo Uribitarte between the Pio Baroja station and the Zubizuri Bridge. Bilbao is part of the Intercultural Cities Project (ICC) of the Council of Europe through the REClNetwork of Intercultural Cities, a model of a city that works for equal rights, duties and social opportunities for people who inhabit them, preventing and questioning prejudices linked to immigration, refugee and cultural diversity, and promoting an environment more prone to intercultural coexistence and to the prevention of discrimination and racism. In this context, Humanae represented all the positive values embodied by the intercultural project and the commemoration of March 2 Ist.

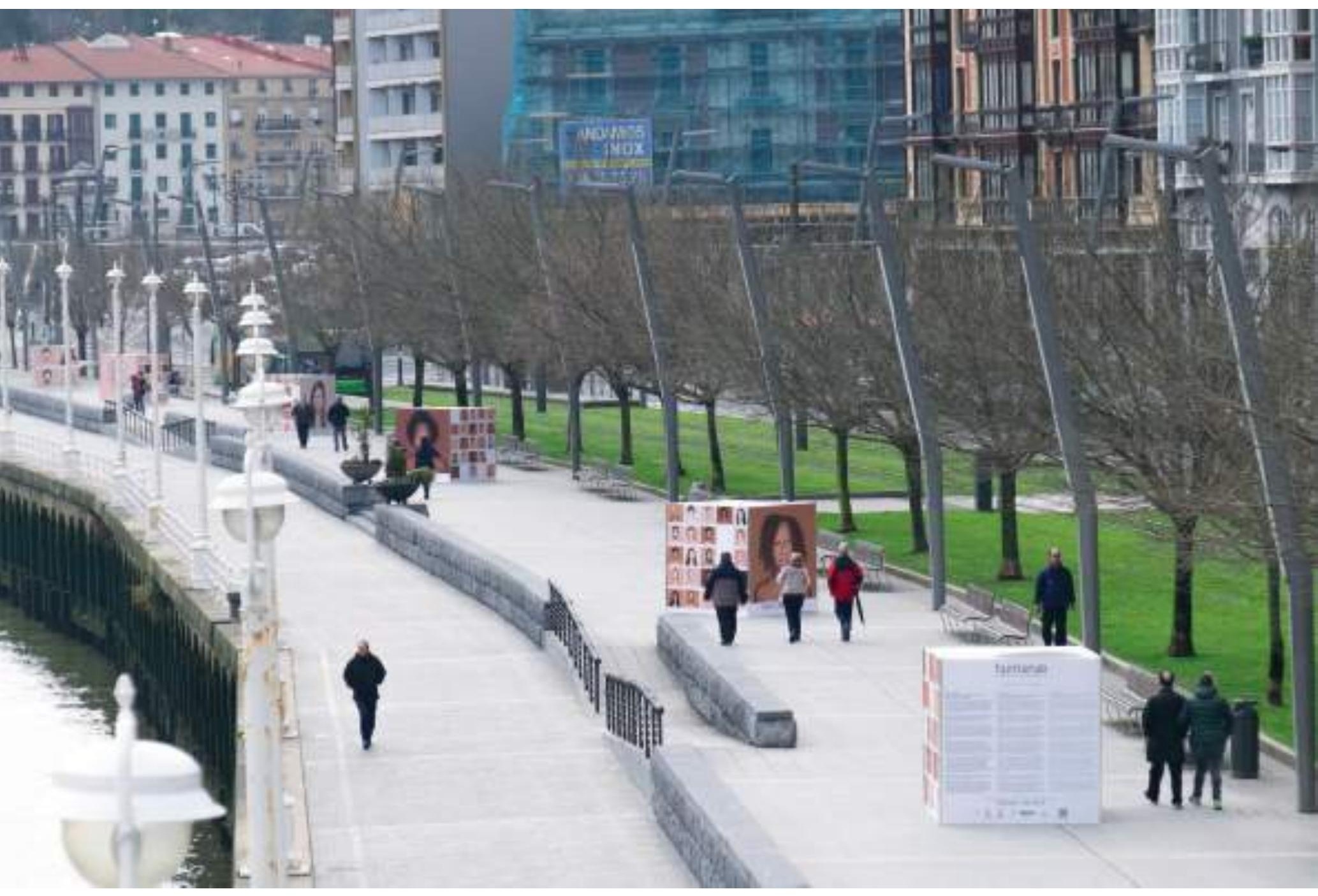

108 | The Journal of Public Space, 3 (2), 2018 | ISSN 2206-9658

City Space Architecture / UN-Habitat 

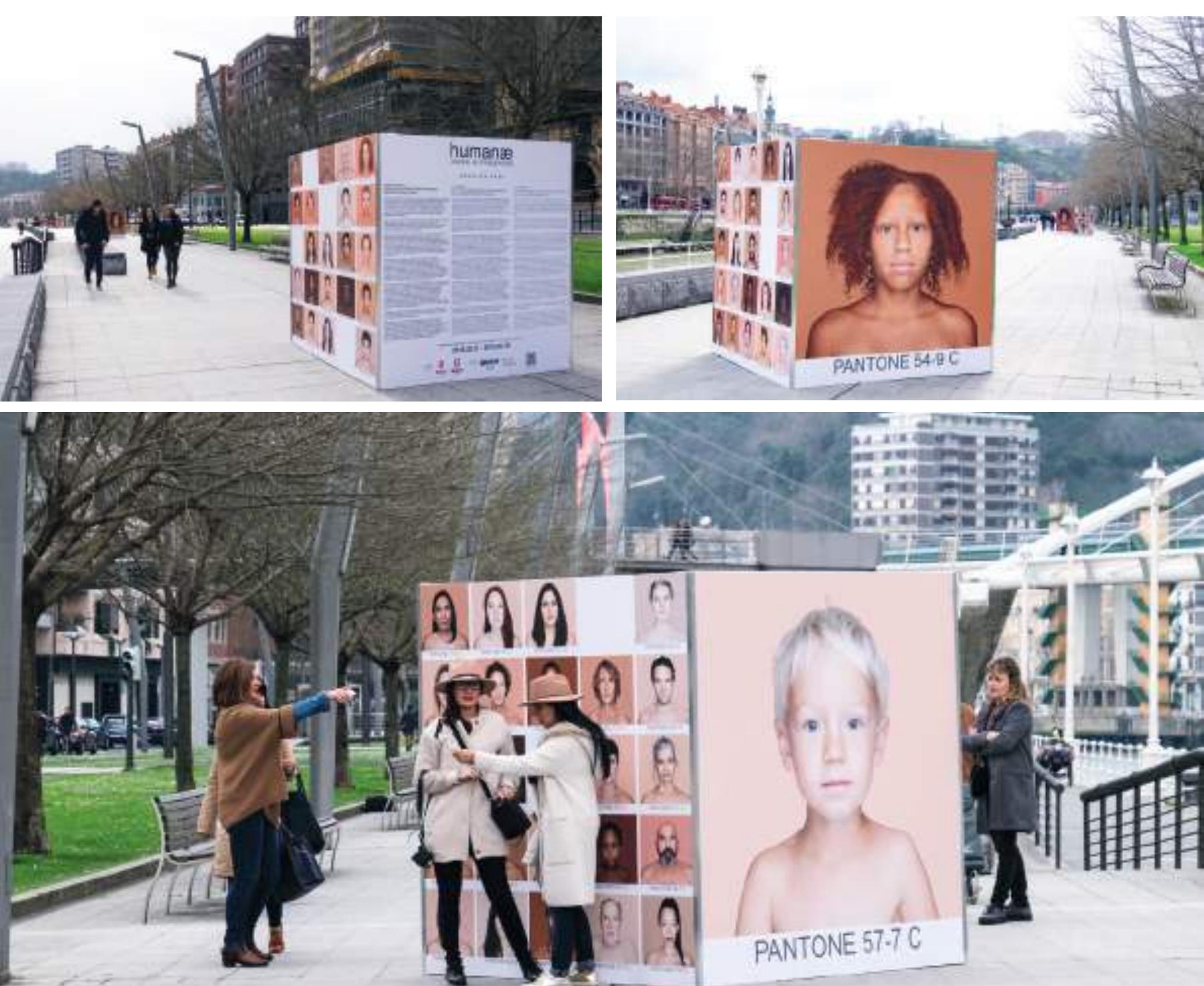
From sidewalk ballet to defending the city
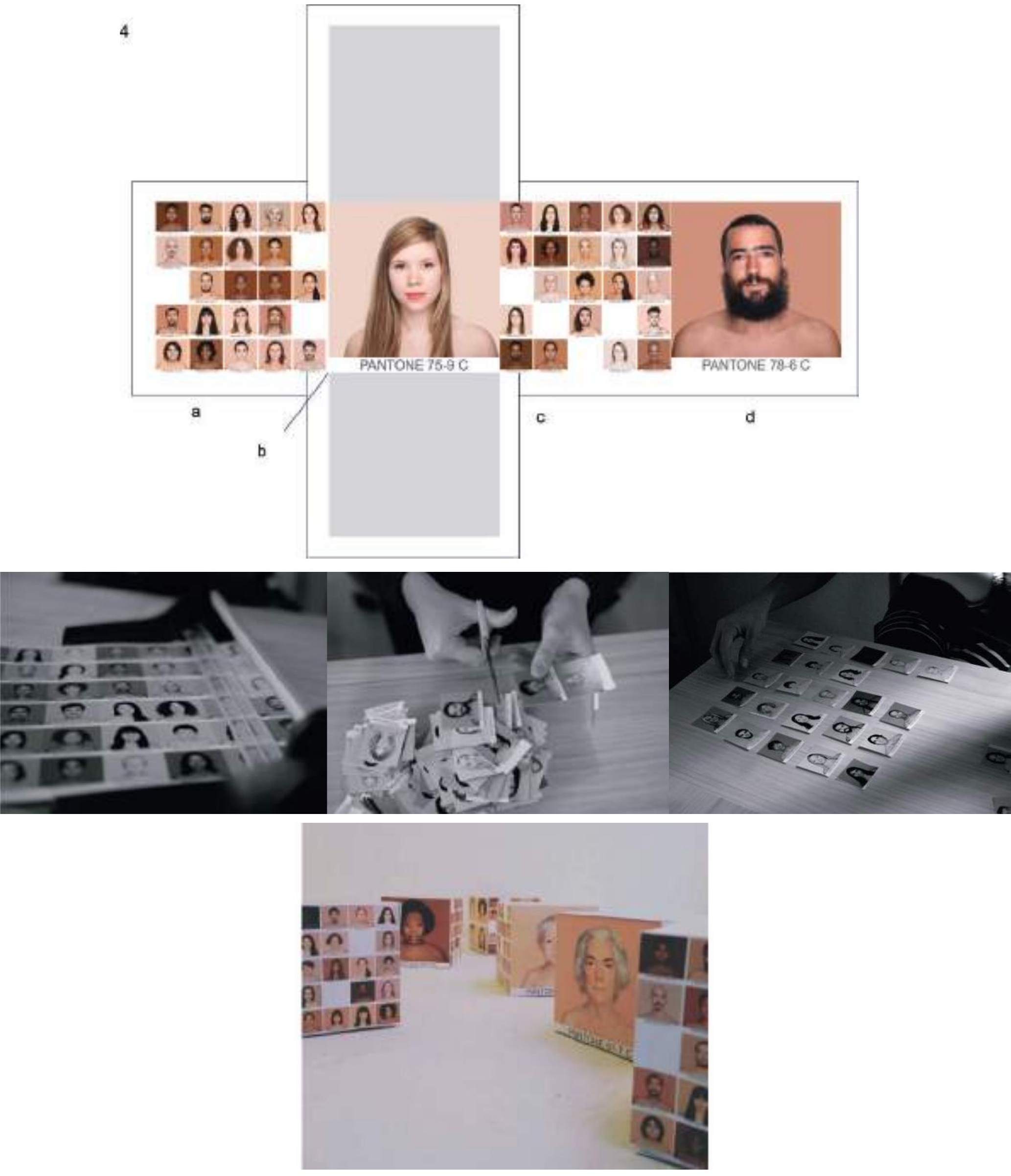

I I 0 | The Journal of Public Space, 3 (2), 2018 | ISSN 2206-9658

City Space Architecture / UN-Habitat 


\section{Urban Layers Project}

Lecce, Gibellina, Cinisello Balsamo (Milano), Italy

Málaga, Spain

Thessaloniki, Greece

June 2016

With a traveling exhibit, Humanae was part of the Urban Layers - New Paths in

Photography, an European Project about photography in the public space, which aims are bringing contemporary art to a wider audience, promoting photographic research and supporting emerging artists. The project was funded by Creative Europe Culture Program - Cooperation Projects, encouraging a broad audience to take part in the cultural development of its territory through an active participation through the use of photography as a form of public and shared art.

Humanae prints traveled between Italy, Spain and Greece, being exhibited in different outdoors and indoor spaces at the Università del Salento in Lecce; Fondazione Istituto di Alta Cultura Orestiadi onlus in Gibellina - Trapani; Fondazione Museo di Fotografia Contemporanea in Cinisello Balsamo (Milano);Arte Contemporáneo GACMA in Málaga; and during the Thessaloniki Museum of Photography's PhotoBiennale.

The challenge of this project was to adapt the same print for the different structures that would be exhibited in different outdoors and indoor spaces in Italy, Spain and Greece. The outdoor exhibitions were held in Malaga, at the Neighborhood of Lagunilla during the UPHO Festival; and at the Seafront Promenade of Thessaloniki, in collaboration with Thessaloniki Museum of Photography, during the PhotoBiennale.

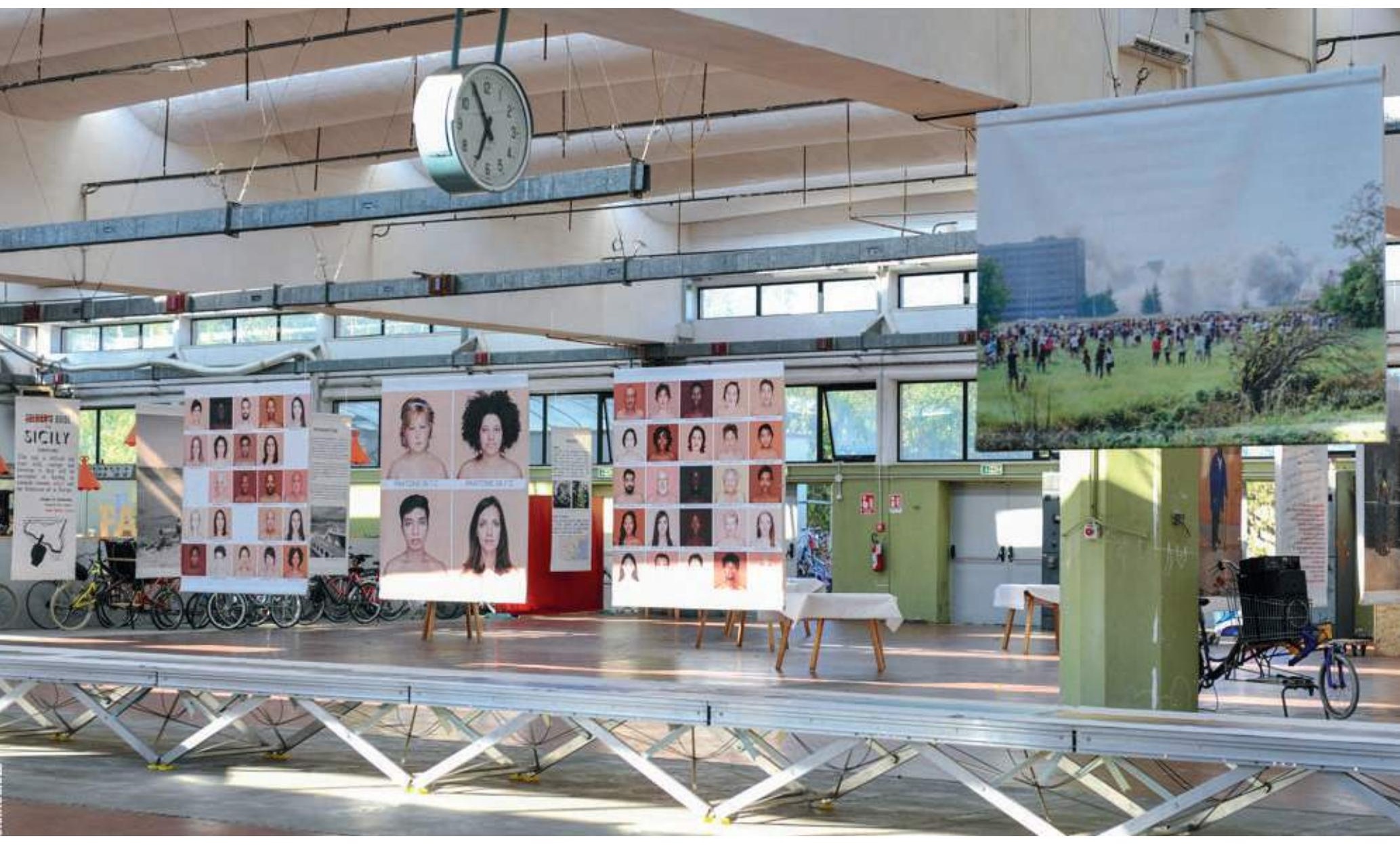

II I | The Journal of Public Space, 3 (2), 2018 | ISSN 2206-9658 City Space Architecture / UN-Habitat 

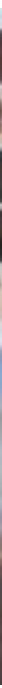

BITUME Photofest, Lecce, Italy. Pictures by Alice Caracciolo.

\section{Identity Flows}

Visual Routes Across the Mediterranean Sea
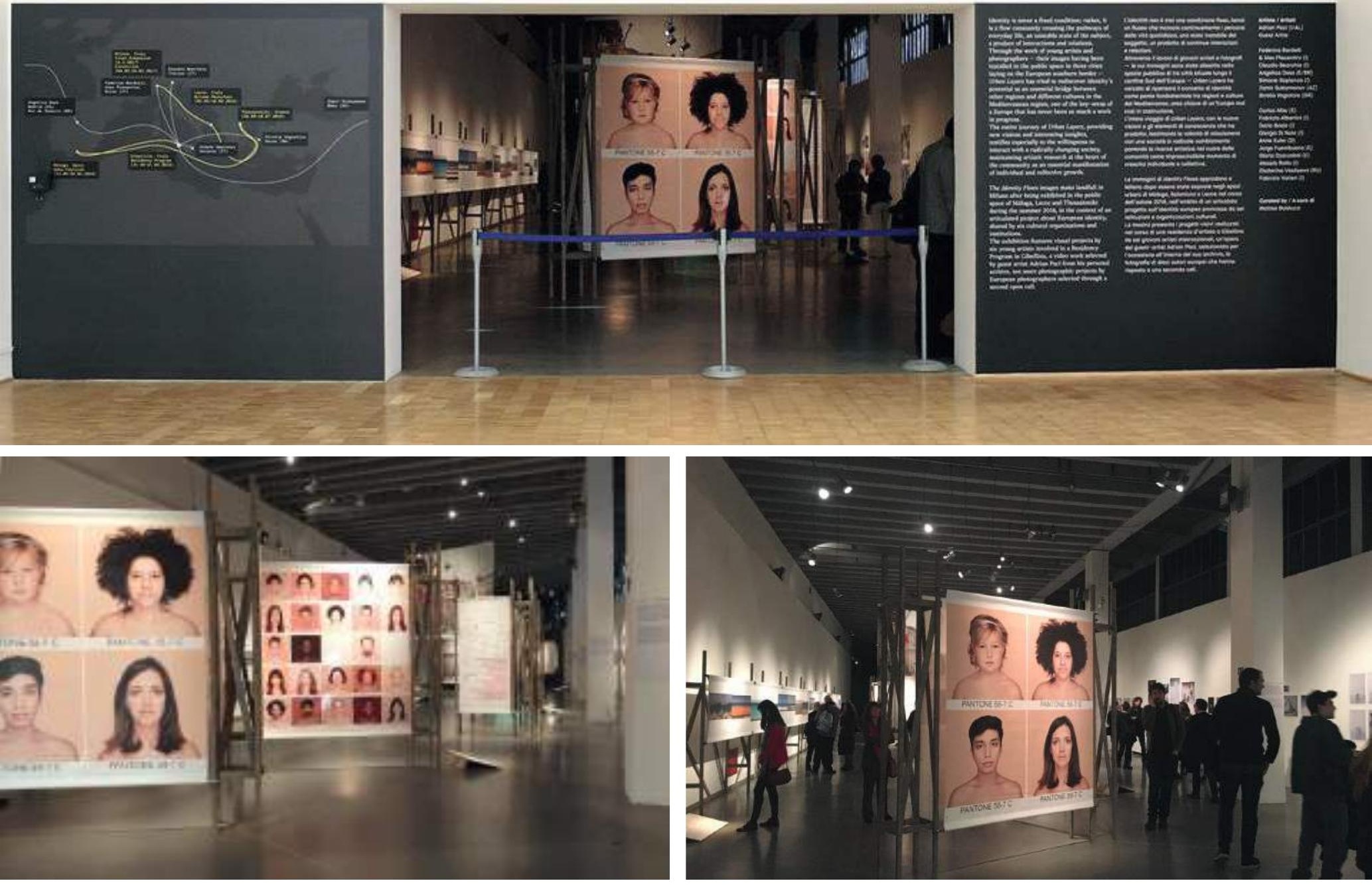

MUFOCO - Museum of Contemporary Photography, Triennale di Milano, Italy.

II 2 | The Journal of Public Space, 3 (2), 2018 | ISSN 2206-9658

City Space Architecture / UN-Habitat 


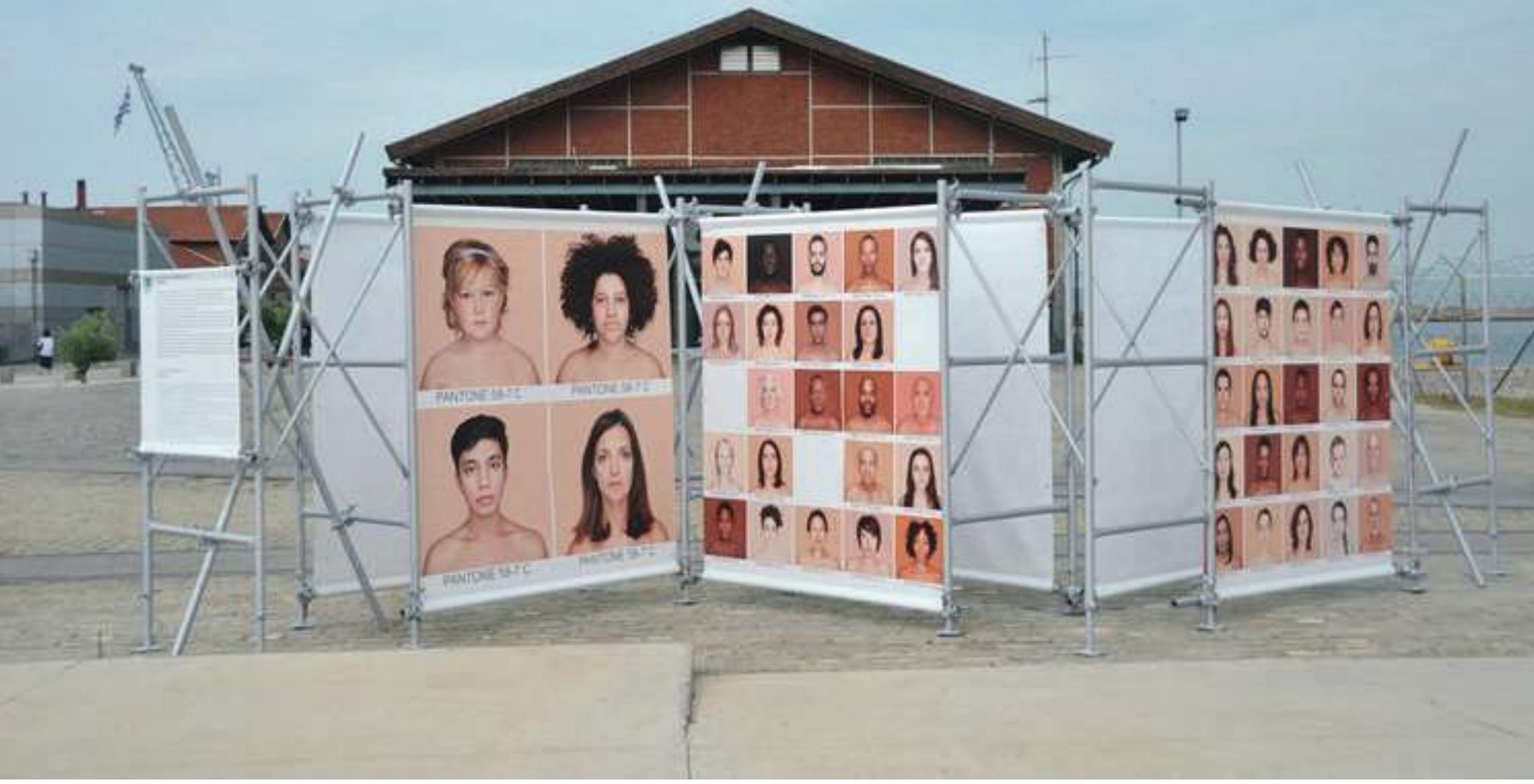

Thessaloniki Museum of Photography's PhotoBiennale, Greece.
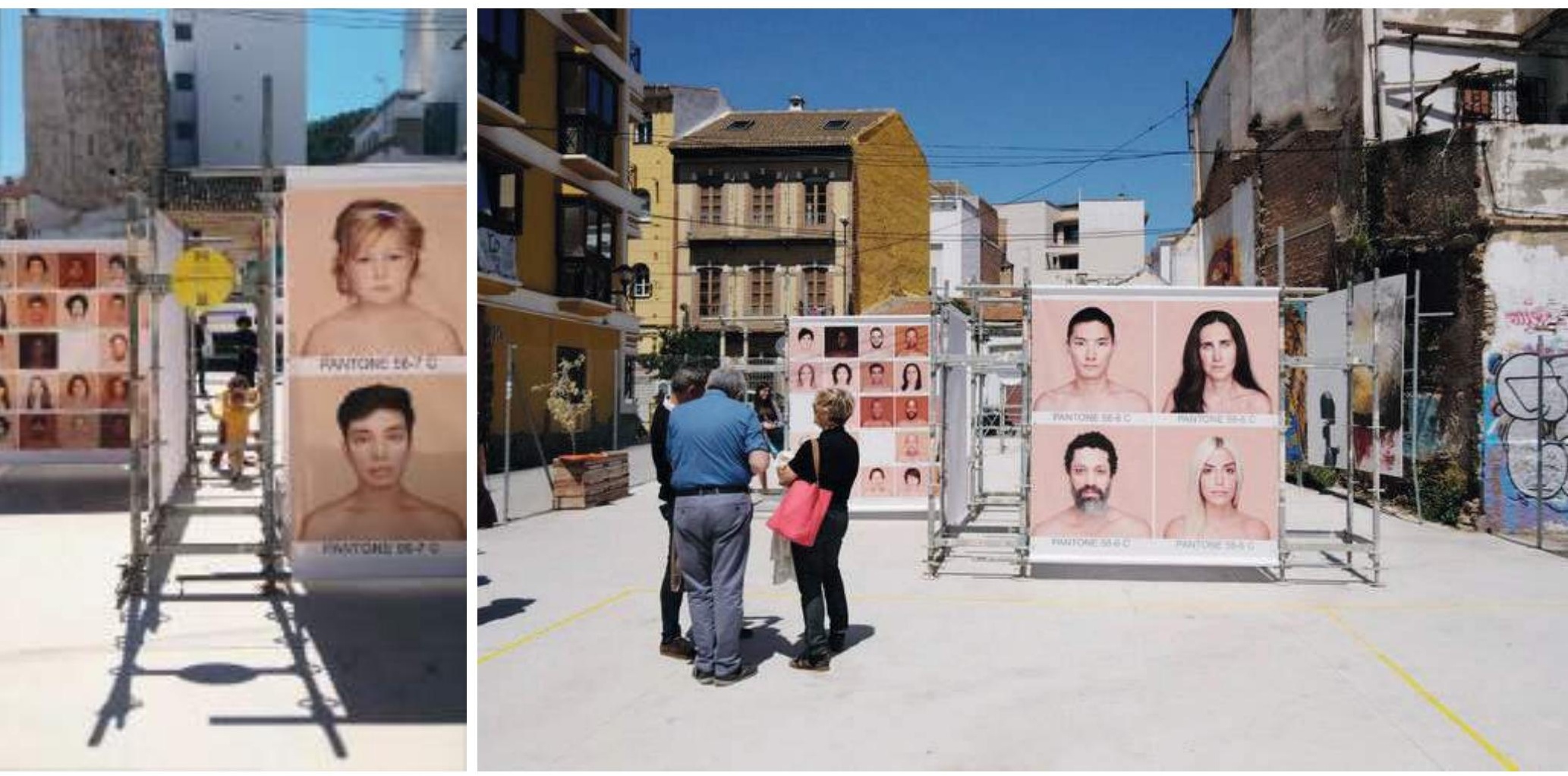

UPHO Festival, Málaga, Spain.

II3 | The Journal of Public Space, 3 (2), 2018 | ISSN 2206-9658 


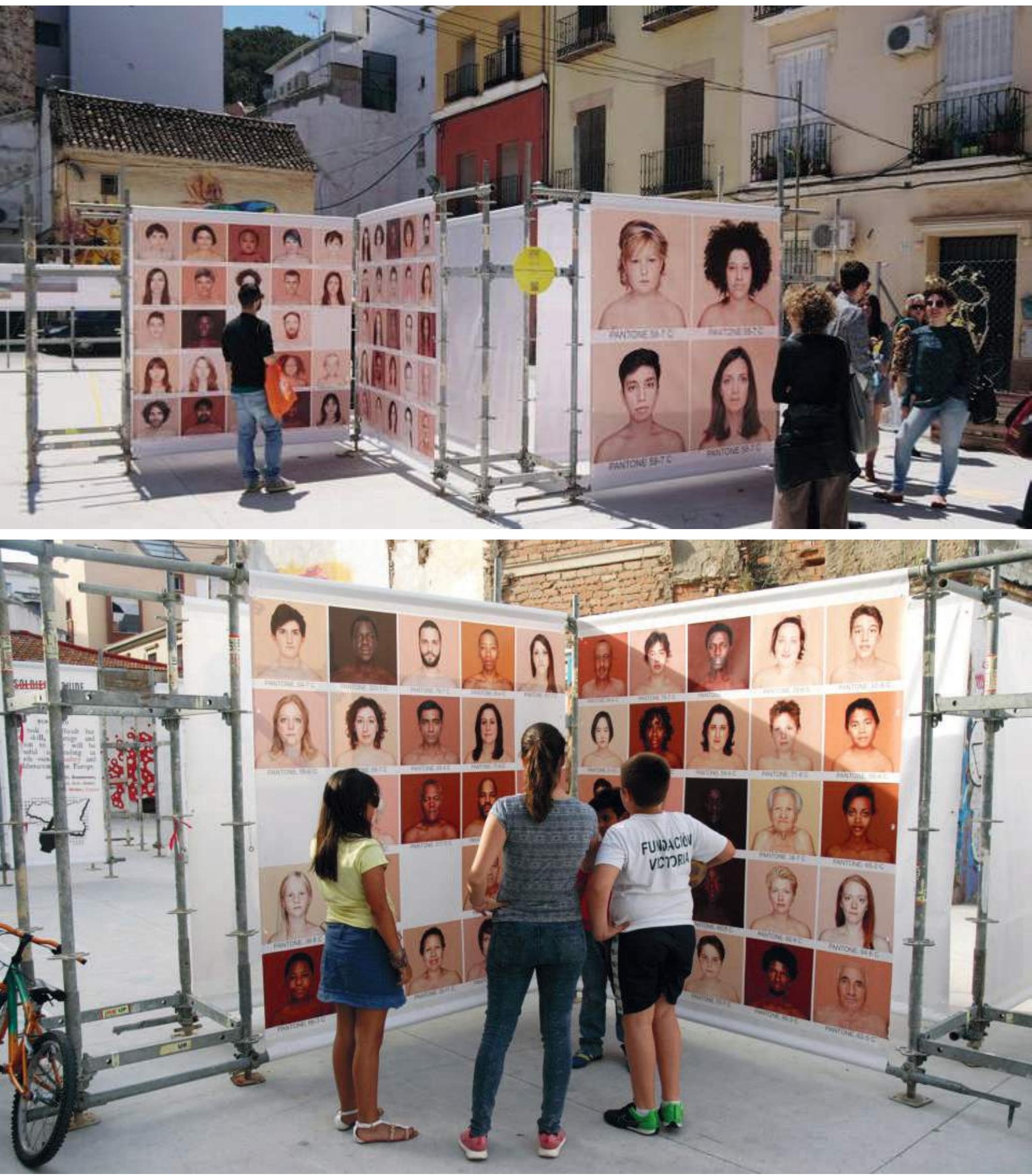

UPHO Festival, Málaga, Spain.

Il4 | The Journal of Public Space, 3 (2), 2018 | ISSN 2206-9658

City Space Architecture / UN-Habitat 
The Journal of Public Space

ISSN 2206-9658

2018 | Vol. 3 n. 2

https://www.journalpublicspace.org

\title{
Using drawing as a tool to explore public space Richard Briggs \\ richard@richardbriggs.com.au
}

\begin{abstract}
With my background in architecture, my approach to better understanding public space is to use a process of exploration, observation and drawing on location, or as it's called in some forums as "urban sketching". With observation I try to understand the elements of the built environment which contribute to the vitality of a city. My drawings become comments on either the political landscape or social context of a particular place. Before I start the drawing process, I explore, observe, and talk to local people, gathering information on the layers complexity that exist in order to better understand place.

This observational approach forms a framework to work within and enables me to begin the process of making an interpretation, through drawing, of a place. A key aim of this approach is to distill what I see into a simple form.

Whether it be a large expansive wall drawing, or a small scale drawing in a sketch book, my artwork has the aspirational aim to provoke a wider discussion about our cities, public spaces, and the built environment. It also tries to look at how people use these spaces, and document what's important to a "soul" of a place and how this approach resonates with its characteristics. Using drawing as a tool to highlight a message has enabled me to express ideas on how public space can be improved and enhanced from a social, political and experiential point of view.
\end{abstract}

Keywords: observation, immersion, data, drawing, message

\section{To cite this article:}

Briggs, R. (2018). Using drawing as a tool to explore public space. The Journal of Public Space, 3(2), II5-I48, DOI 10.3289I/jps.v3i2.III 2

This article has been accepted for publication in The Journal of Public Space. Please see the Editorial Policies under the 'About' section of the journal website for further information.

This work is licensed under a Creative Commons Attribution - Non Commercial 4.0 International License https://creativecommons.org/licenses/by-nc/4.0/ 
In a moment of time when the balance between the public and the private is shifting in favour of the latter, it is important that a close eye is kept on the status of the public spaces in our cities. Vital public space tends to emerge as a product of numerous competing forces. Planning guidelines, levels of regulation and attitudes can strangle or let flourish behaviours which enliven these areas which are so key to thriving cities. It can be argued that the vitality of public spaces hinges on their ability to facilitate a diversity of, often unexpected, usages and interactions, by a broad spectrum of people over varied time periods.

Eva Lloyd and Giacomo Butte; Extract from Street Life Studies: Cambodia publication 2015; Faculty of Built Environment, University of New South Wales, Sydney.

My approach to better understanding public space with regards to retaining and enhancing this vitality, is to use a process of exploration, observation and drawing on location, or as it's called in some forums "urban sketching". This approach to documenting the city can then be used to canvas a wider discussion on our built environment. It raises questions such as - What's good about a city? What's successful? What needs to be retained? and What could be improved? At the forefront of this process, is the question of how people use and activate space (and built form). I use the process of drawing to form a view on the city, spaces and people, highlighting issues that are either positive or detrimental and usually they will have a political or social angle. One of the positive aspects that I find about drawing on location is that it provides a very immersive experience within a city scape. This allows my mind to be fully focused on making an interpretation on what I see, which in many cases, can be visually overloading. My aim is to reduce what I see into simple terms, into simple forms, and purge the drawings to make sure that only what is necessary appears on the page. This process of reduction also allows me to make decisions on how to relate a drawing to a particular message, something which I try and make the basis of any drawing or artwork. One of the keys aspects to the process that I undertake, whether it be in a city which I know well, or don't know at all, is to explore and observe before any drawing starts.

This observational approach forms a strategy to work within and enables me to start to select "drawing subjects". These subjects usually have a common theme and provide key messages about a city's character. I look at the elements which makes a place interesting and or try to understand pressing issues from a social point of view. For example, on a recent trip to Porto in Portugal, I spent a week looking, observing and talking to local people. This process generated a greater understanding about the city and certain characteristics (albeit in this case a fairly superficial level) and allowed me to formulate an approach to any drawings that I did of the city. I was interested in the subject of change and gentrification. Based on my limited observations as an outsider, I did a series of drawings of signage on abandoned buildings, as I believe that this started to talk about the changing nature of the city.

Another positive aspect of drawing on location is the opportunity to meet local people in the street whilst doing this. This, in many cases, can lead to conversations that can increase your knowledge about a place and how people use public space. For example, you find out what type of activities occur on Saturday afternoon at the market, or what future plans lay in wait for a building, a street or a square. This level of exposure, being in 
the place that you are documenting, gives license to produce a drawing that has more depth and contextual meaning. Due to this level of exposure, layers of political, social and geographical information end up being part of a drawing. Drawing on location also proves to be a valuable educational tool as well, to learn and become more aware of your surroundings. For example, you'll witness first hand over time about how a public space might respond to climate, and how this can affect how people use and move through space. You'll also see the impact of built form and vegetation and how this might provide informal opportunities for activities that will enable people to stop, linger, sit and watch, all activating public space. Jan Gehl, the architect and urban planner, talks a lot about the spaces "in between" buildings, and this is certainly one aspect that l'm interested in trying to capture through drawing.

This process of exploration, observation and drawing on location can be a valuable tool when documenting a new place with fresh eyes. The work that I have undertaken in the area of Surry hills in Sydney is an example of a "slow burner" project, whereby I have been studying the streets and spaces since 2005. This has allowed me to document through drawing changes or gentrification in the area. Some of these changes are instant and rapid, with some taking many years to emerge. It's also allowed me to form a strong connection with the area and, importantly, the community. I have listened to vast amounts of interesting stories that characterise the area and the people, most of which have in some way impacted the message I am trying to portray through my drawings. A part of this drawing project in Surry Hills, was exhibited in 2010 at the Surry Hills library, a place that forms the heartbeat of area for the local community. What was important about this milestone in this ongoing project, was that it provided a great opportunity to engage directly with the wider community in a public forum. It provided a platform for a greater understanding of the area, and thus influenced directly my drawing of the area. The exhibition was also a catalyst for a public debate on Surry Hills. A series of public workshops were also held, which gave an opportunity for the people in the area to join in and through sketching add layers of history, knowledge, and community aspirations to my drawings.

The drawing work from Cambodia is an example of how I document when spending a shorter length of time in one location, producing a more initiative response to place. These drawings were done in a series of visits to Phnom Penh which form part of a yearly short course called Street Life Studies: Cambodia. This course is for Built Environment students from the University of New South Wales in Sydney and from the Royal College of Fine Arts in Phom Penh (RUFA). I am part of a team of academics and practicing architects that co run the course, and collectively we are interested in how we can encourage students to study, understand, document public space. Again, using process of observation first, then drawing, but with the added layer of data collection. The students then suggest small scale urban interventions with the aim of improving public space from a practical and experiential aspect.

Data collection has also provided a basis for some of the larger wall drawings that I have completed. When using this approach, it can not only give the artwork great substance and depth, but it also allows you as the artist to give way to risk, surprise and control. Letting go of knowing where the artwork will go and following the lead of an acquired data is something that can lead to some very interesting results.

The wall drawing located in a foyer of an office tower on Sydney for the Naked Duck Group was, as a concept, a response to how people travelled to work. I gave over 100 office workers a survey questionnaire asking them questions such as what were their 
experiences of the city, what mode of transport did they use to travel to work, and what were significant moments on their daily commute? I spent two weeks following in the footsteps of the office workers, on trains, buses, ferries, bike and on foot, trying to capture through drawings what they thought were significant moments or landmarks whilst in transit, as well as adding my own experiences. Their daily routes to work formed an organic framework and backdrop for the more detailed part of the artwork. This approach allowed the artwork to be totally experiential; to be about how at a human scale we relate to spaces within a cityscape, some of which are like large canyons, and some of which are intimate and enclosed. The cinematic nature of moving through public space allowed me understand better how the city works from a network point of view. The networks that allow people to move through space to their destination is something that has always interested me greatly when looking at cities, and this artwork was an opportunity to explore this in the Sydney context. During the process I also observed how people use public space, whether it be a train platform, a park, a cycle lane, a street, a footpath, or a bus seat. It became an interesting study in human behaviour and also sharpened and widened my observational skills.

Another project that used data as a basis for a piece of public artwork was mural completed on a garage door in Marrickville, Sydney. This was part of a local council initiative that invited local artists to complete pieces of public artwork on walls and the like that had a problem with unwanted tagging. The varied demographic of the local area was something that interested me personally. With fifty one different nationalities living in the local area and by using information from the national population census, my aim was to document and use this diversity and cultural richness of the community to drive the artwork and to highlight this condition. The garage door sits in a well-used laneway, but still provides surprise and intrigue with any passerby. As a graphic it has a certain quality, but I was more interested in the artwork forming a commentary on how as city, Sydney's public space, its parks, its streets, its cafés, its supermarkets and local squares are occupied by a demographic that makes the city a cultural hotspot.

Whether it be a large expansive wall drawing, or a small-scale drawing in a sketch book, my artwork has the aspirational aim to provoke a wider discussion about our cities, public spaces, and the built environment. It also tries to look at how people use these spaces, and document what's important to a "soul" of a place and how this approach resonates with its characteristics. Using drawing as a tool to highlight a message, whether it be through private practise, or through an academic lens, has enabled me to explore opportunities to express ideas on how better public space can be improved and enhanced from a social, political and experiential point of view. 
Richard Briggs is a practising artist and UK registered architect based in Sydney, Australia. After graduating from the Manchester School of Architecture in 1999, Richard worked for architects such as SOM in London, and SJB in Sydney before forming his own design practice in 20I0. Working on a mixture of small scale residential and art projects, he also teaches design at University of New South Wales in Sydney. Richard's artworks and drawings encourage a different way of looking at our built environment. He looks at how we can describe our cities, streets and laneways, by filtering what we see to produce focused sketches which can portray a strong social, political or environmental message. Using this approach, he has completed several large scale murals for clients such as DEXUS Property Group, Lend Lease and Sydney councils.

Richard is also part of urban sketchers (USK), a worldwide organisation which encourages drawing on location, and ran workshops and lectures at the USK Symposium held in Manchester, England in 2016. With his architectural background, his interest in the built environment, and way of conveying a sense of place through drawing, Richard co-runs a course called Street Life Studies: Cambodia, at the faculty of the Built Environment, University of New South Wales in Sydney. This course encourages students to use drawing as a tool to understand and compare public spaces in both Sydney and Phnom Penh in Cambodia. As a past director of Emergency Architects Australia (EAA), Richard also has a strong interest in social and community based projects. He has worked on projects in Timor-Leste and spent a year working in the field as part of a rehabilitation and reconstruction program for over 100 schools in the Solomon Islands. This grassroots experience focused on the construction of a prototype school, which won the International category at the 2010 Australian Timber Design awards and the World Architecture Community award in $201 \mathrm{I}$. This varied range of experience enables Richard to cross the boundaries between, architecture, art and community based design, with collaboration being a key driver in how projects and ideas are realised.

www.richardbriggs.com.au

Instagram: richardbriggs_artist 


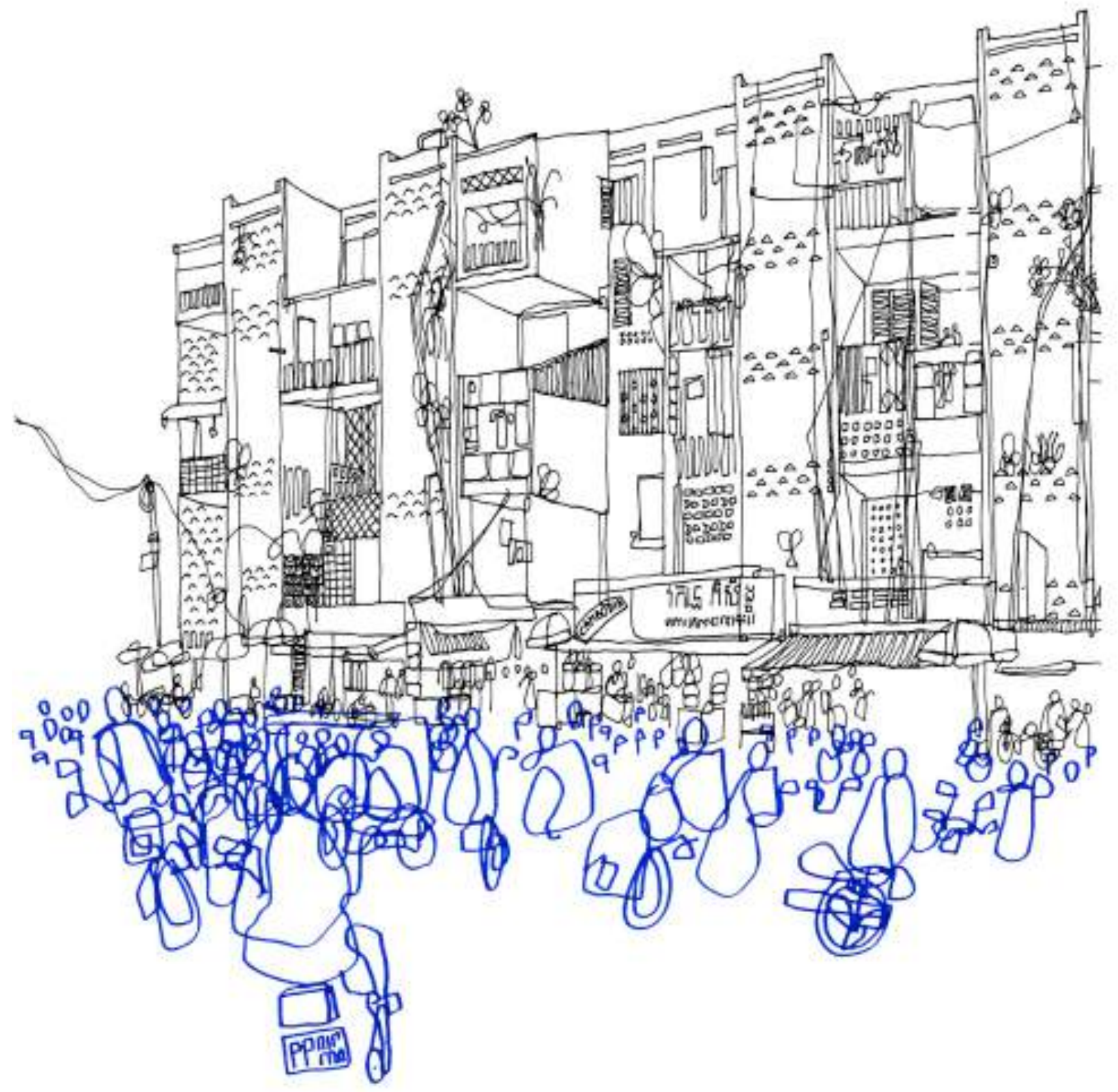

I20 | The Journal of Public Space, 3(2), 2018 | ISSN 2206-9658

City Space Architecture / UN-Habitat 


\section{Surry Hills Survey}

2005 - ongoing

The area of Surry Hills in Sydney has undergone significant change and gentrification over the last decade, and I have been documenting this shift through my practice of drawing. My interest in the area originally stemmed from the diversity in building typology in both scale, materialality, and the differing streetscapes that created different types of public space. I was interested in capturing the sense of place and was captivated by how a typical two up, two down terrace can be next to an old seven storey industrial warehouse which has since been turned a shop, then a cafe and then a pop up clothing store. This diversity and type of change meant that some areas were always in flux but others were static and this dynamic is of great interest when thinking about the nature of the streetscape. One aspect that I was also interested in was the role of the trees in the area both from a climate control and streetscape point of view. They enhance the streets, and are a key characteristic of the area that provide rest bite from the summer heat and winter rain.
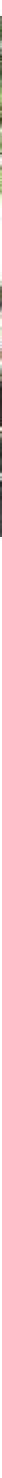

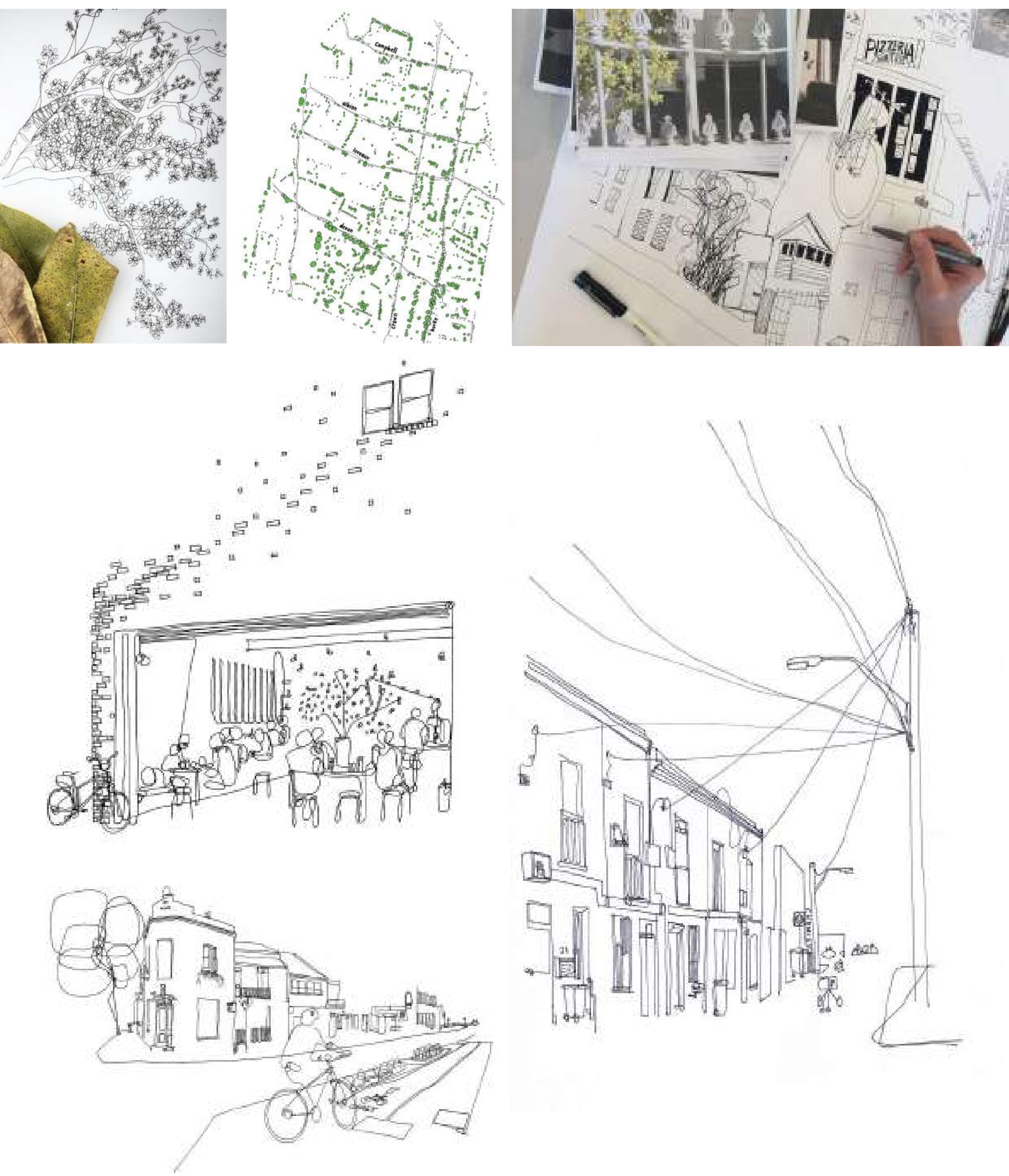

I22 | The Journal of Public Space, 3 (2), 20 I8 | ISSN 2206-9658

City Space Architecture / UN-Habitat 
In 2014 I was invited by the City of Sydney to exhibit this ongoing work in the Surry Hills library as part of an overall theme of 'endangered areas' within the city; places that through gentrification could lose their identity and character. Through this theme I focused my drawing work on what I thought was worth retaining and what made the place interesting and completed a series of drawings that told a story from a cultural, social, historical and political point of view. Over 100 individual drawings formed a larger mural that was displayed in the foyer of the library. This abstract map represented my own personal view on Surry Hills and was solely based on my immersion within the community. The key aim of the exhibition was to start a wider discussion on what the local community thought was interesting about the area, what was important and what defined it's characteristic, and a series of workshops were held to establish this. The local participants would draw over and add to my sketches of the area, with the aim to tell a wider story and start a dialogue about memory and future aspirations and needs for the area of Surry Hills.

This project is currently ongoing, and I have started to collaborate with other local groups that are also telling stories about the place with the overriding aim that the streets, parks, architecture and culture of the area is not lost to insensitive development.
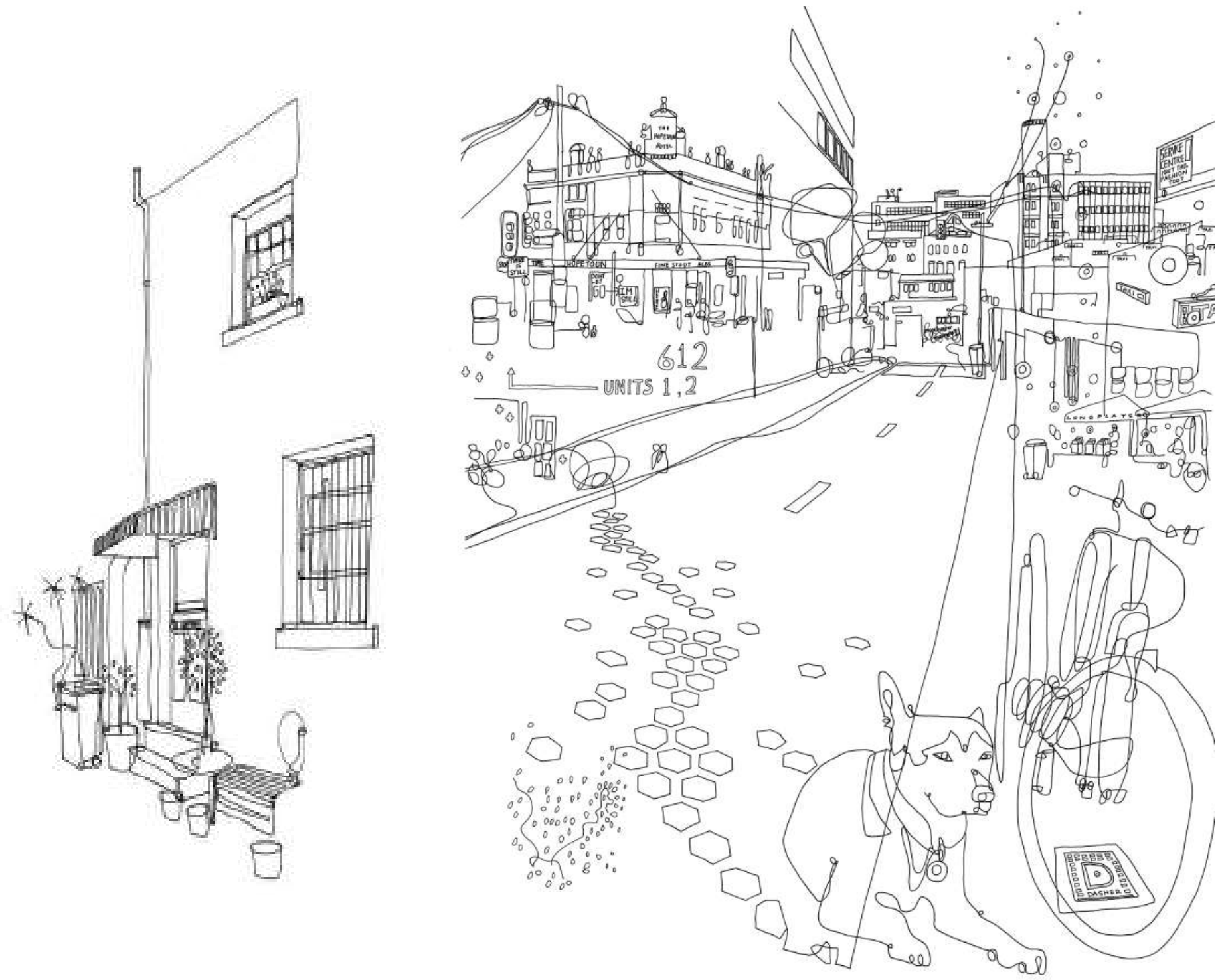

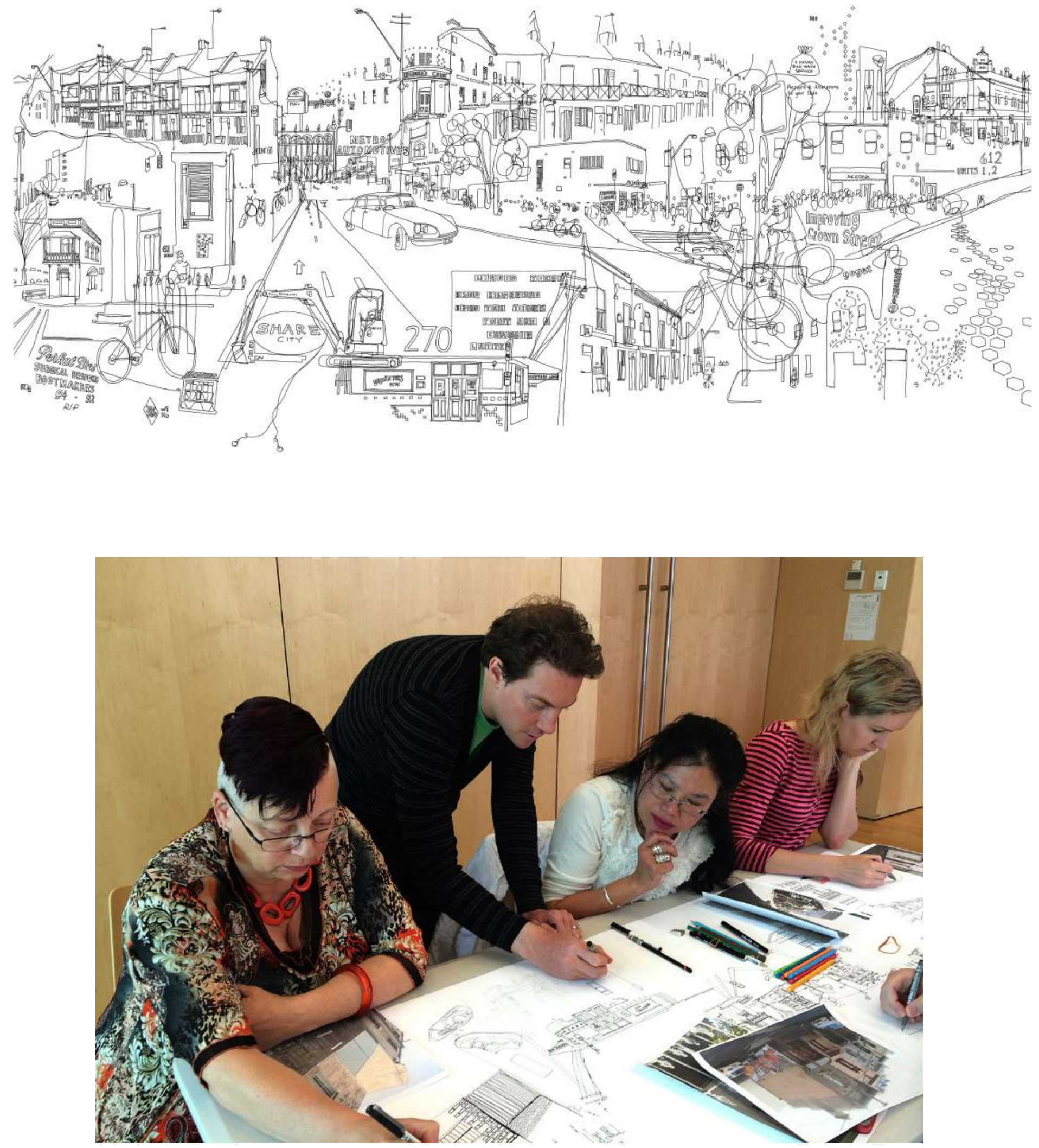

Photo credit:Victoria Johnstone

I24 The Journal of Public Space, 3 (2), 2018 | ISSN 2206-9658

City Space Architecture / UN-Habitat 

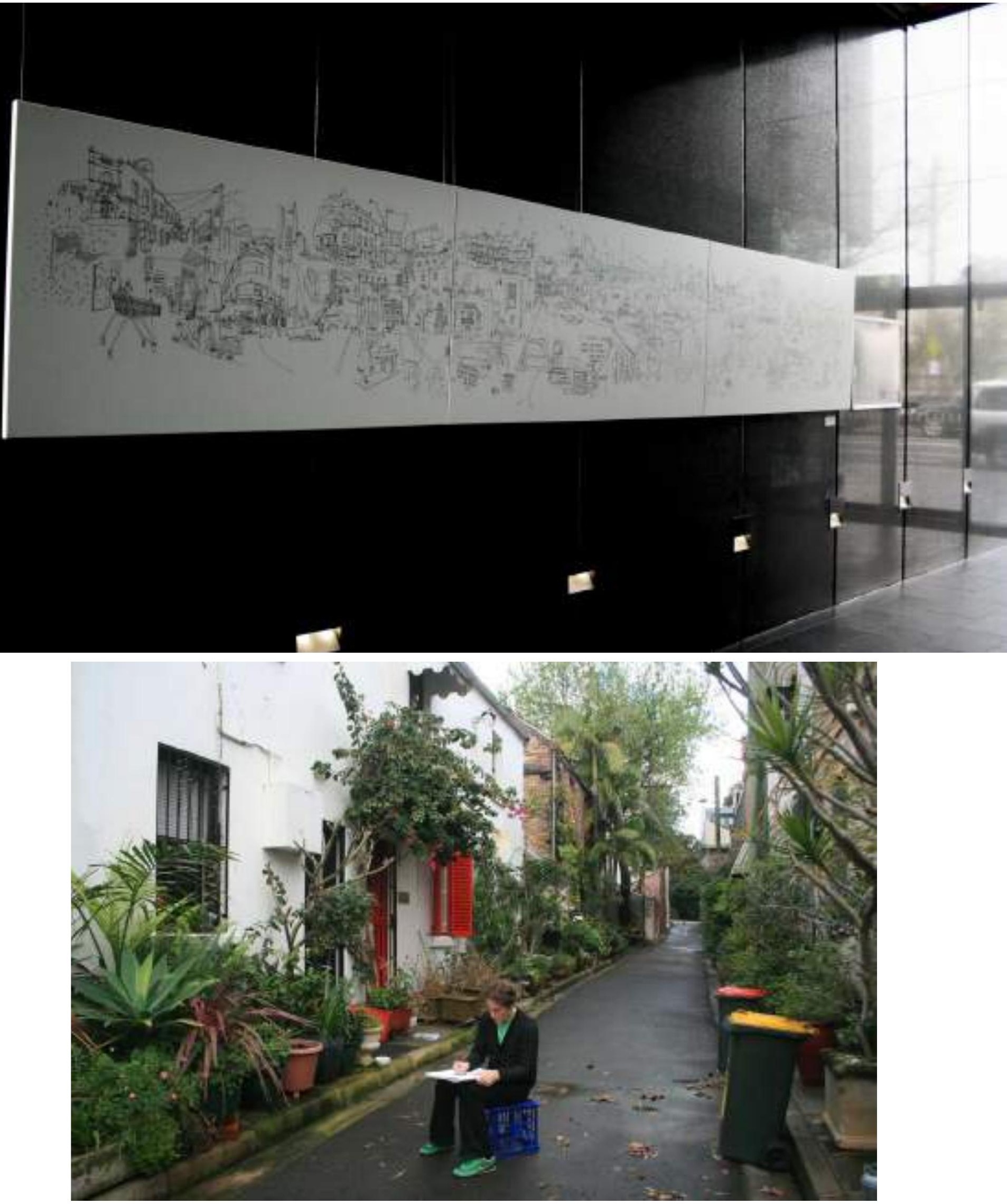

Photo credit: Amanda Sun

I 25 | The Journal of Public Space, 3 (2), 2018 | ISSN 2206-9658 


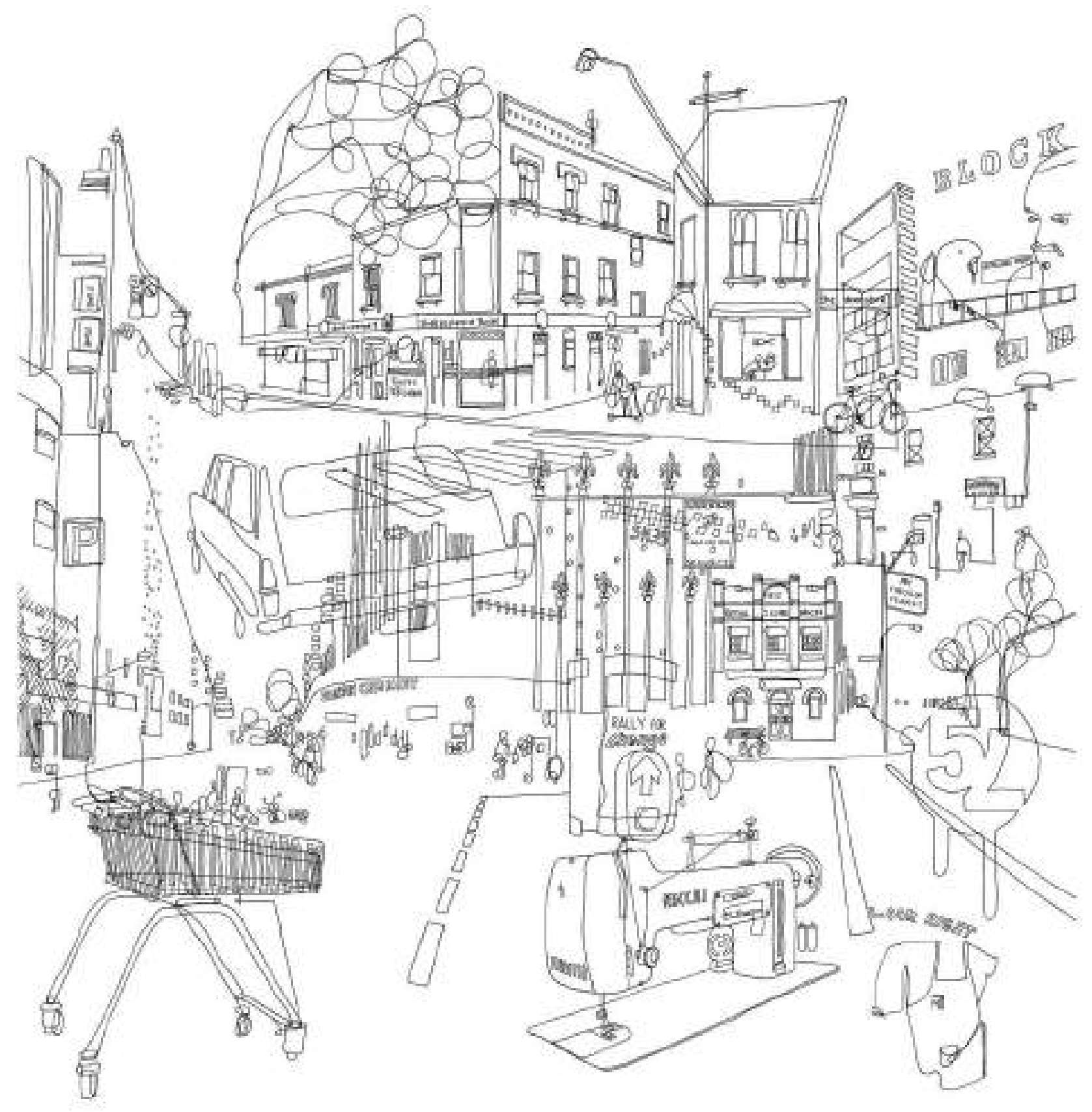




\section{Urban sketching}

2005 - ongoing

Drawing on location can help to understand how public space is used, how a city works and what makes a place interesting or unique. This approach to observing and documenting urban landscapes is an approach that I have utilised in many places around the world. I am part of a worldwide organisation called 'urban sketchers', which provides an opportunity to teach this approach in workshops both in Sydney and Internationally. In 2016 I ran workshops at the Urban Sketchers International Symposium in Manchester, England. During these workshops I encouraged participants to think about the "why" and the "what" when drawing. Not only from a public space point of view, but also how they can tell a valid story through drawing. A good example of how this approach can develop a better understanding of place over a relatively short period of time, are drawings completed in Phnom Penh, Cambodia completed in 2015 and 2017.

These were done in conjunction with a short elective course run annually for the Faculty of the Built Environment at the University of New South Wales, Sydney called 'Street Life Studies: Cambodia'. I am part of team of professionals that guide students through a process of observation and drawing on location, with the aim of developing small scale interventions that would improve the public realm. This series of drawings was completed to provide examples to students, focusing elements which make the streets of Phnom Penh interesting. Students also experiment with graphic treatment to emphasise how people are using the spaces on the streets, or to focus in on important aspects that give the streets vitality.

This series of drawings also demonstrates the value of having a message behind a sketch with the aim to tell a story, whether it be social, political, cultural or environmental.

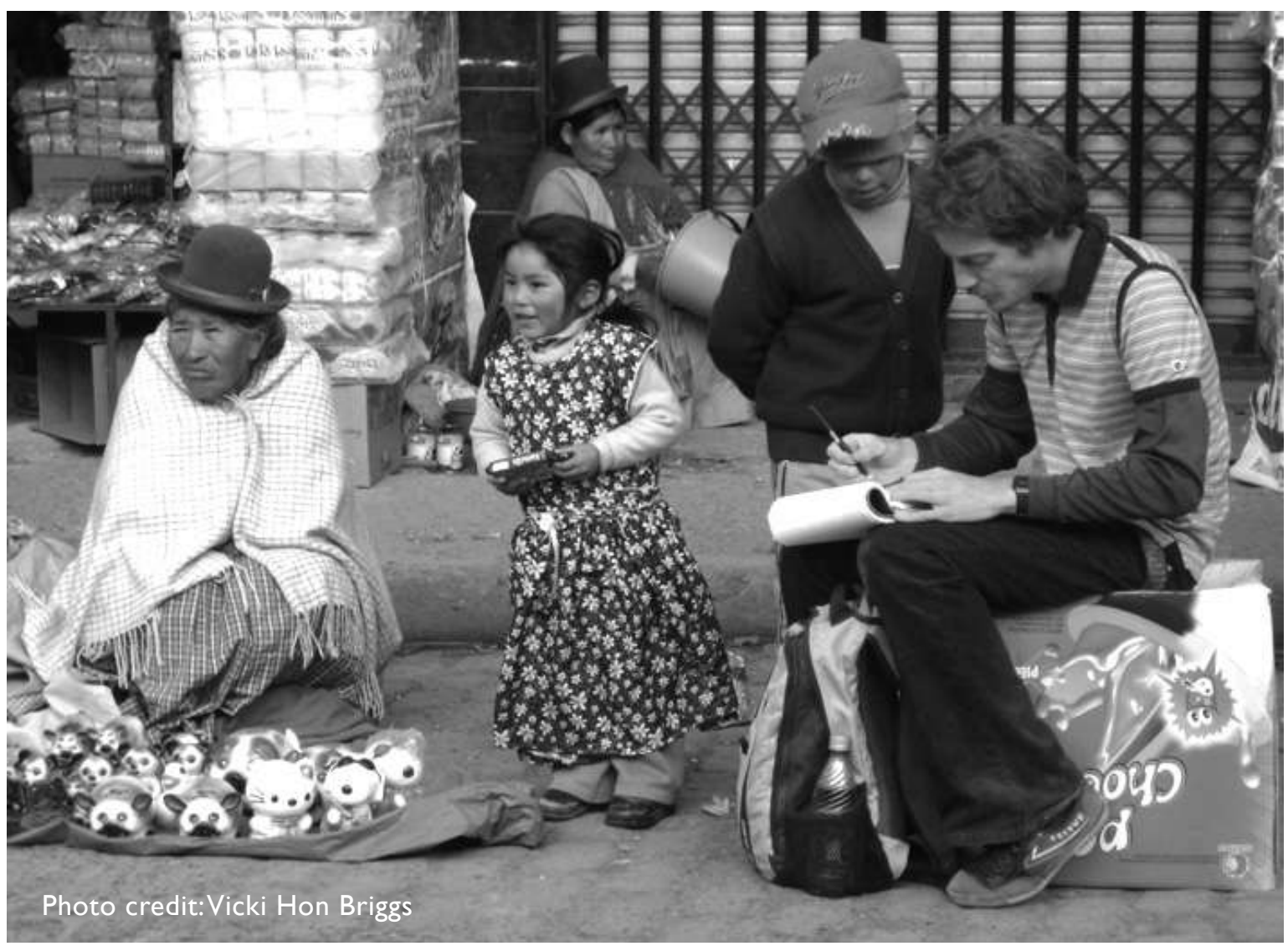

I 27 | The Journal of Public Space, 3 (2), 20 I 8 | ISSN 2206-9658 City Space Architecture / UN-Habitat 


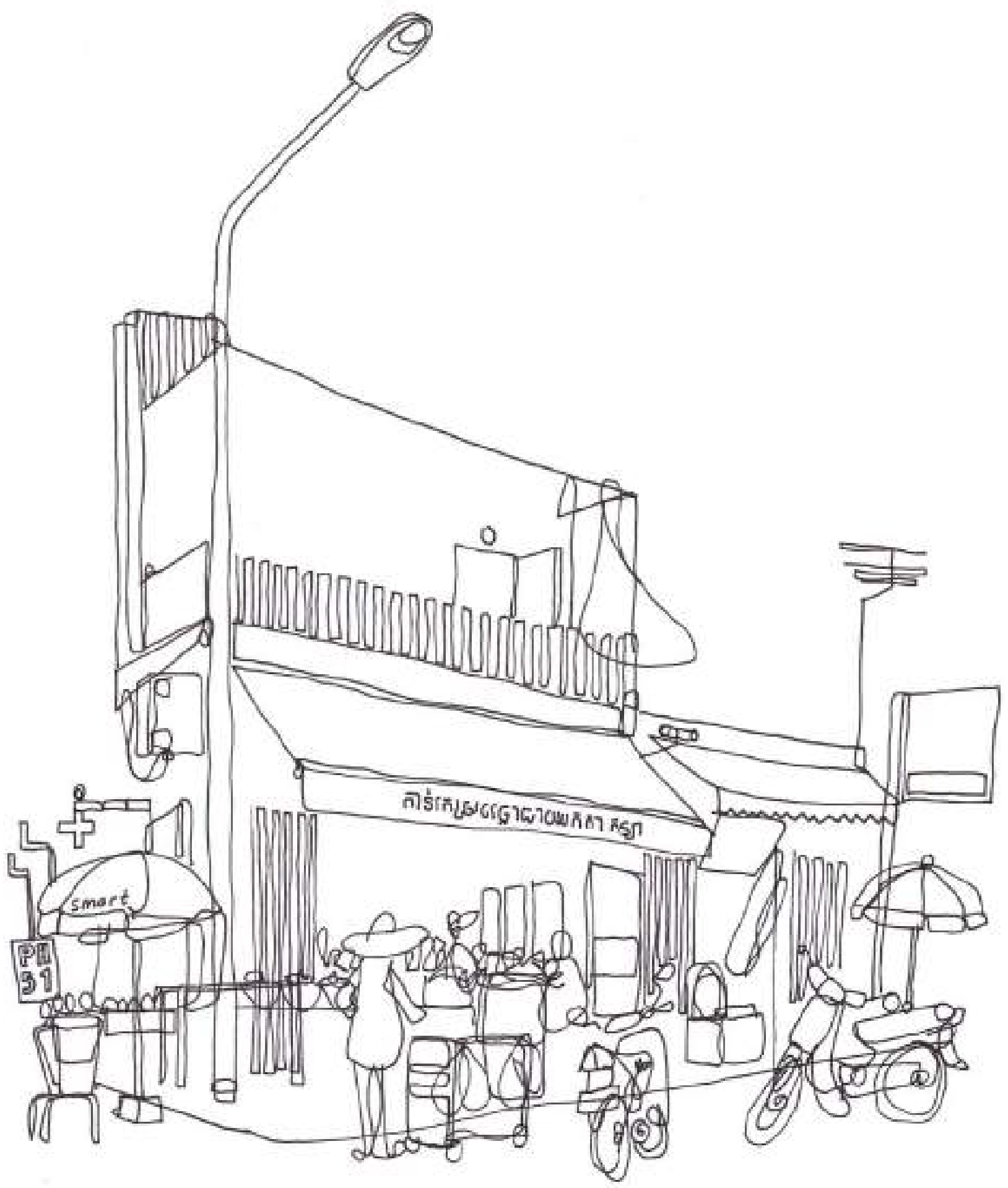




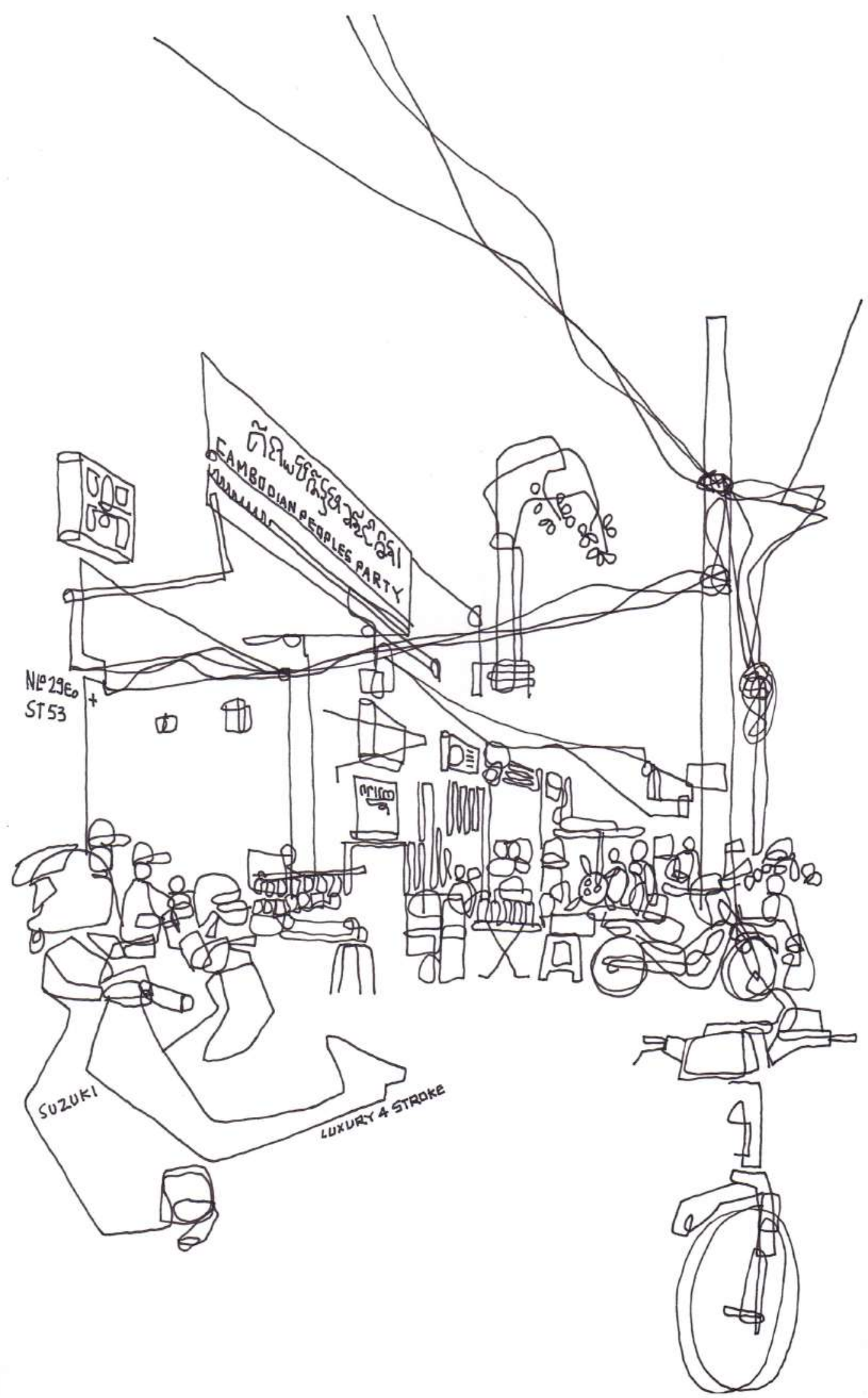

I 29 | The Journal of Public Space, 3 (2), 2018 | ISSN 2206-9658 


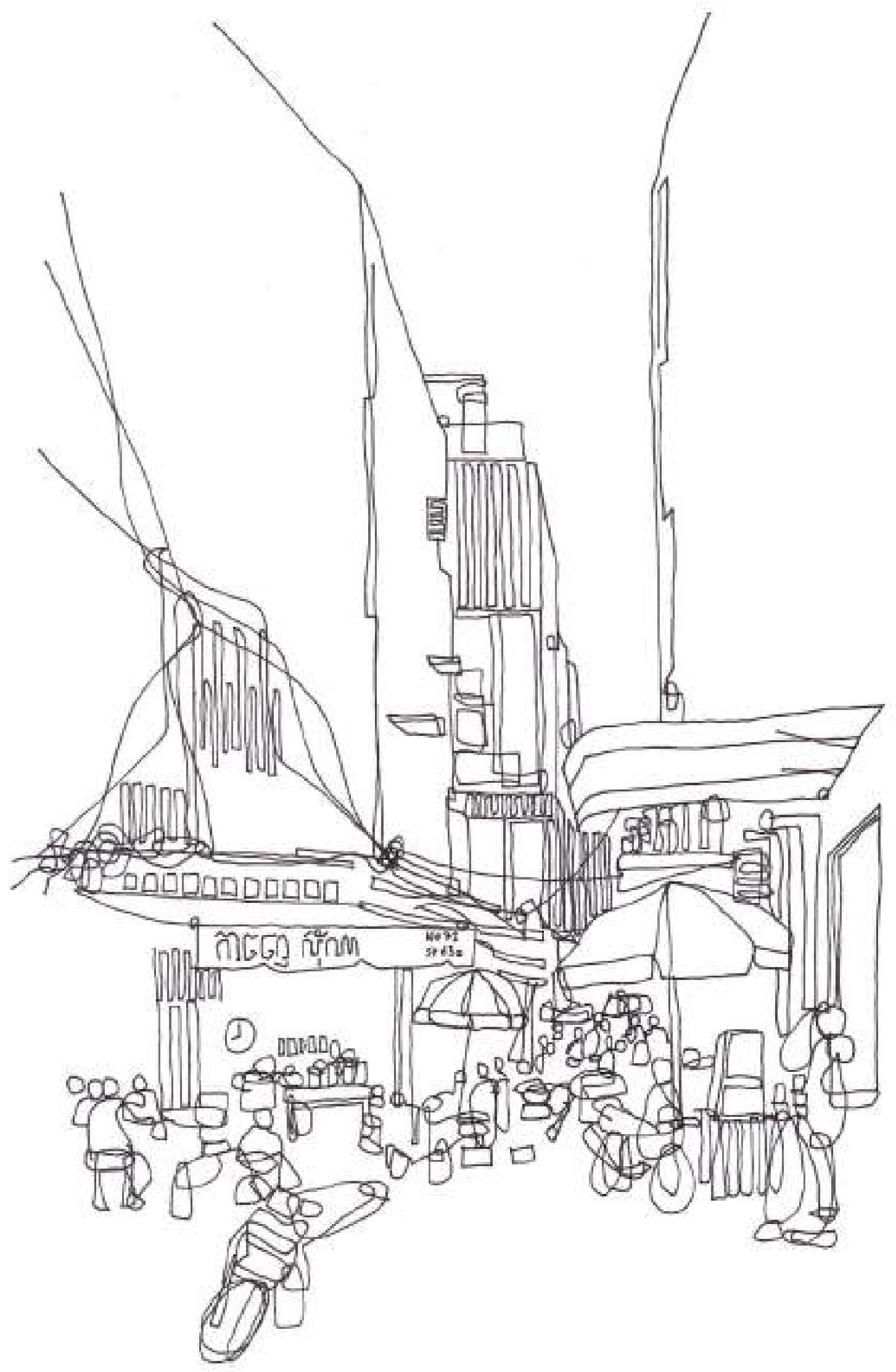

I30 | The Journal of Public Space, 3 (2), 2018 | ISSN 2206-9658

City Space Architecture / UN-Habitat 


\section{City network mural}

2017

I was commissioned by the Naked Duck café group, who are based in Sydney to produce a $25 \mathrm{~m}$ long mural that would occupy a public foyer in one of Sydney's office towers.

With over 3,000 people passing through the space on an average day, I was interested in exploring the relationship between the office workers and the café itself, one being somewhat dependent upon on the other on a day to day basis. The focus of the mural was to celebrate the users of the tower, and how they travelled to work through the city. It was also an opportunity to conceptually think about moving through the cityscape. You catch glimpses of parks, buildings, streets, and people which can add a cinematic quality to an everyday journey. A short simple survey was distributed to all users of the café asking questions about their journey to work; point of origin, what mode of transport was used, and what were the landmarks (obvious or less obvious) that stood out along the way. Using this data over a two week period, I became a city commuter and followed all the journeys from the surveys (over I50 were received) on trains, boats, buses bikes and cars.

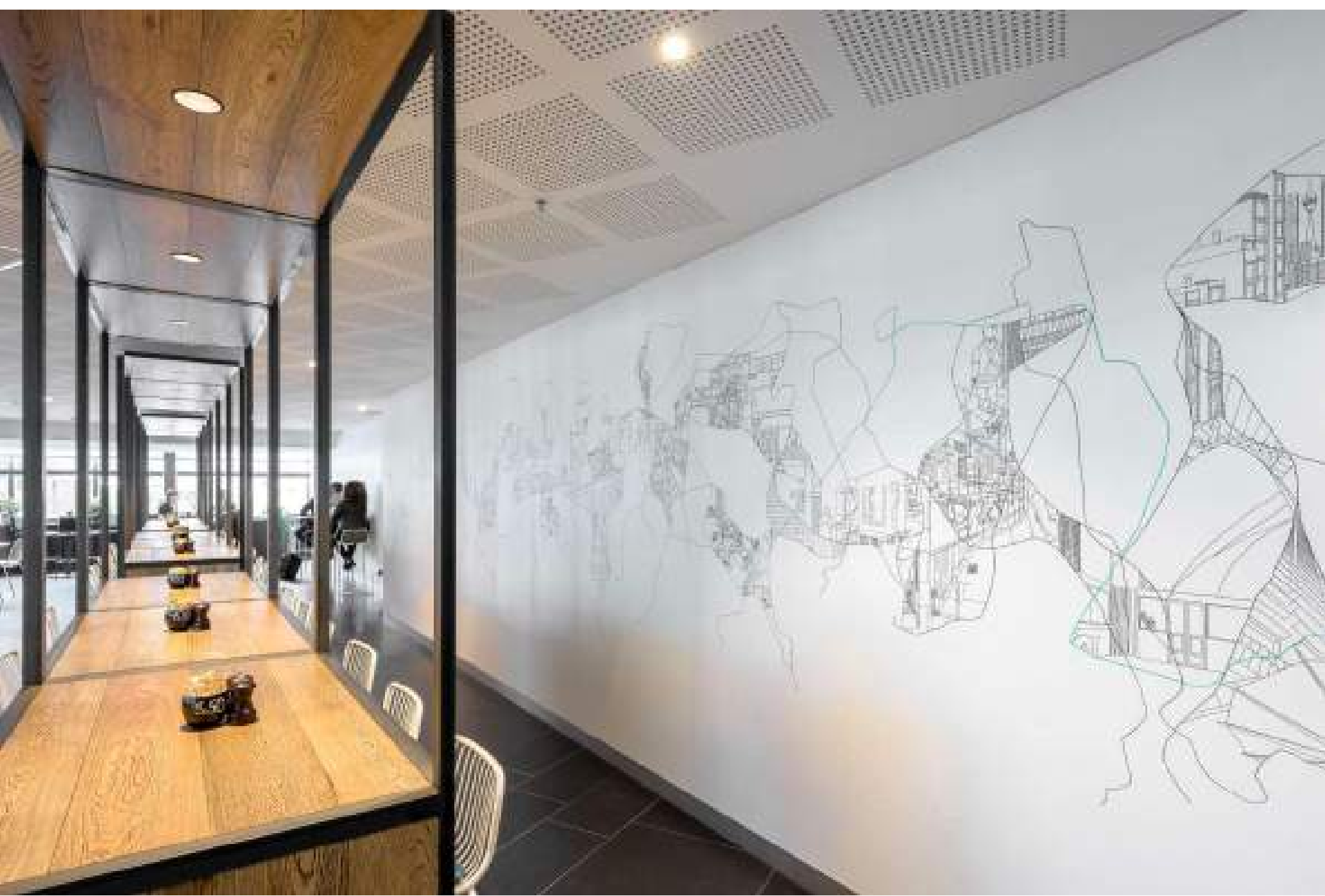

Photo credit: Ben Guthrie 

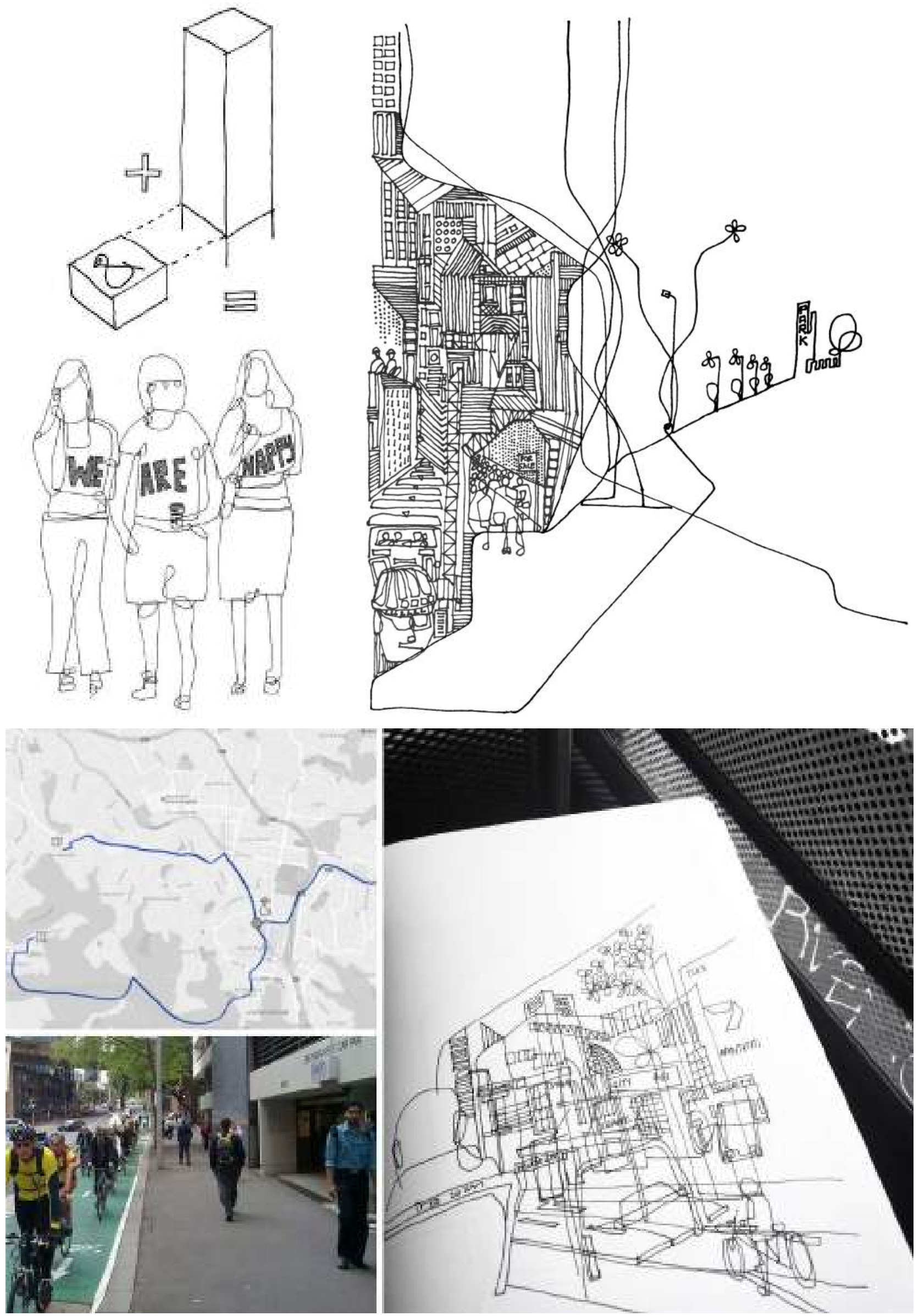

I32 | The Journal of Public Space, 3 (2), 2018 | ISSN 2206-9658

City Space Architecture / UN-Habitat 
On these journeys, which enabled a greater understanding on how the city operates daily, I documented through drawing landmarks that were highlighted on the surveys, as well and other points of interest. A combination of over 150 individual drawings, some of which simple and some more detailed, I was able to 'stitch and overlay' these together to form an abstract mural. The journey routes were mapped out and were used to form an organic line work for the mural, with the pockets where these lines intersected and crossed filled with details from the journey drawings. This playful use of density and space through linework related directly to the experience of moving and 'slicing' through the city scape, whether it be on a train, bus, a bike or on foot.
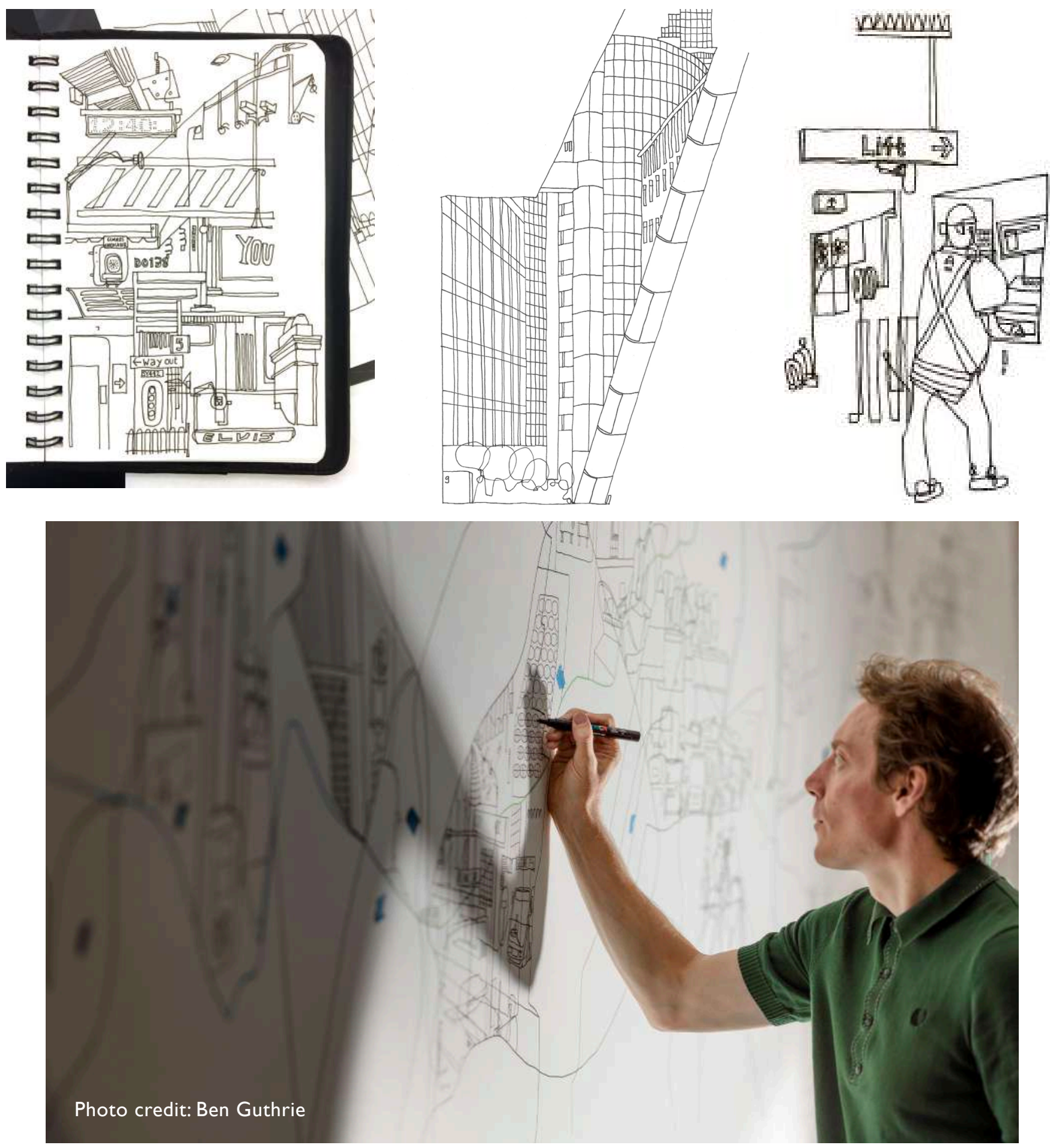

I33 | The Journal of Public Space, 3 (2), 2018 | ISSN 2206-9658 City Space Architecture / UN-Habitat 

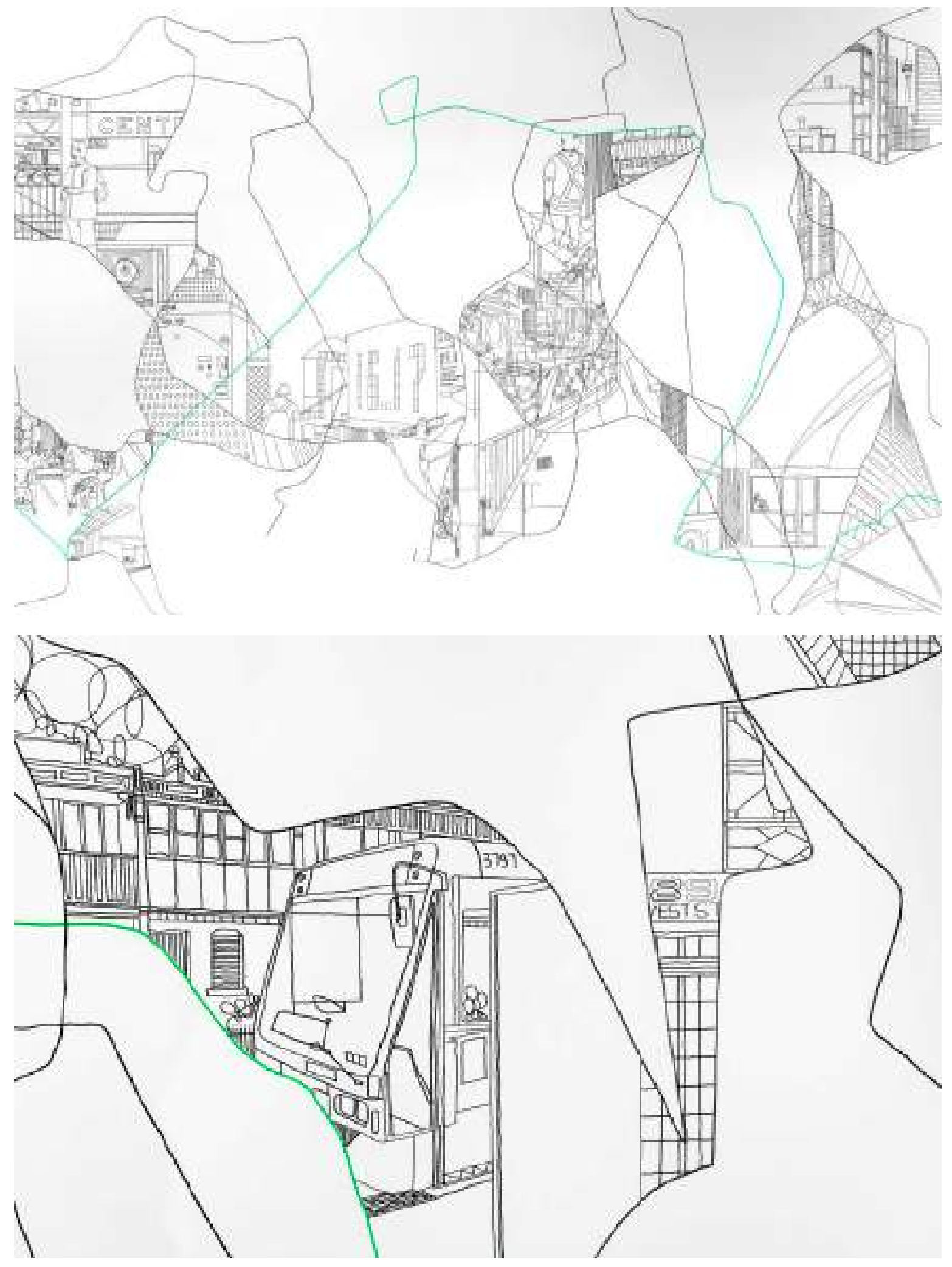

I34 | The Journal of Public Space, 3 (2), 2018 | ISSN 2206-9658

City Space Architecture / UN-Habitat 


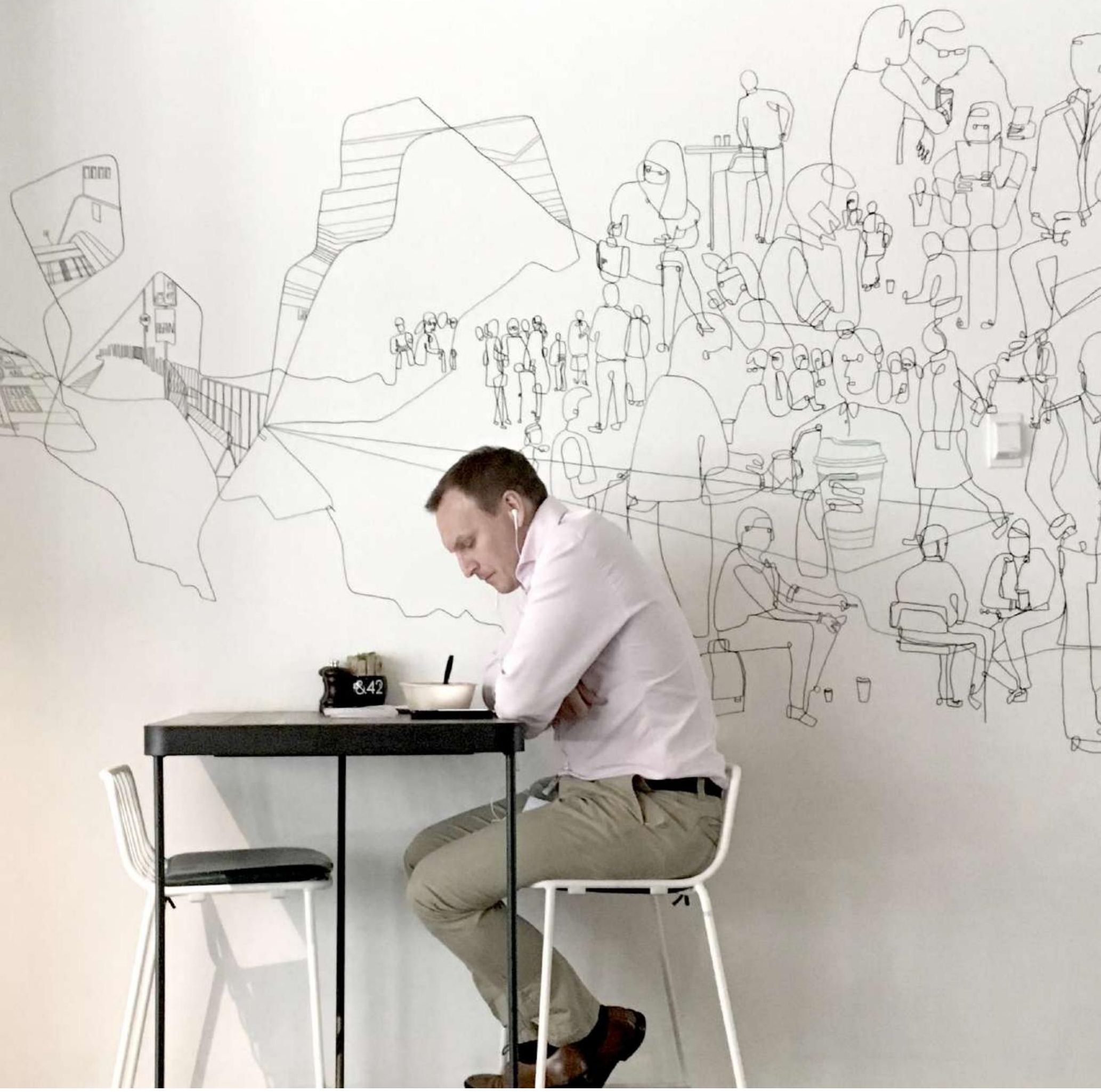




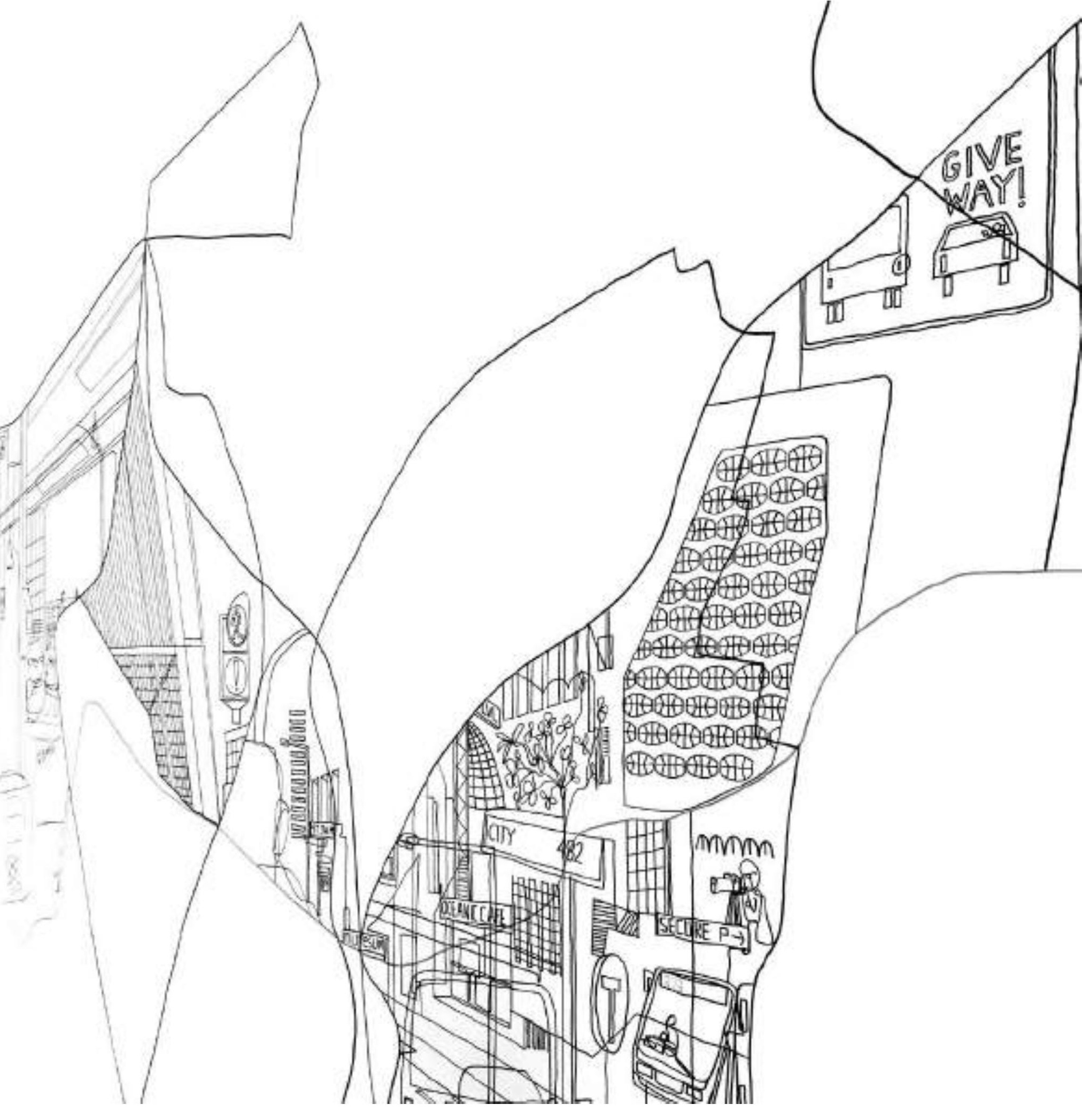



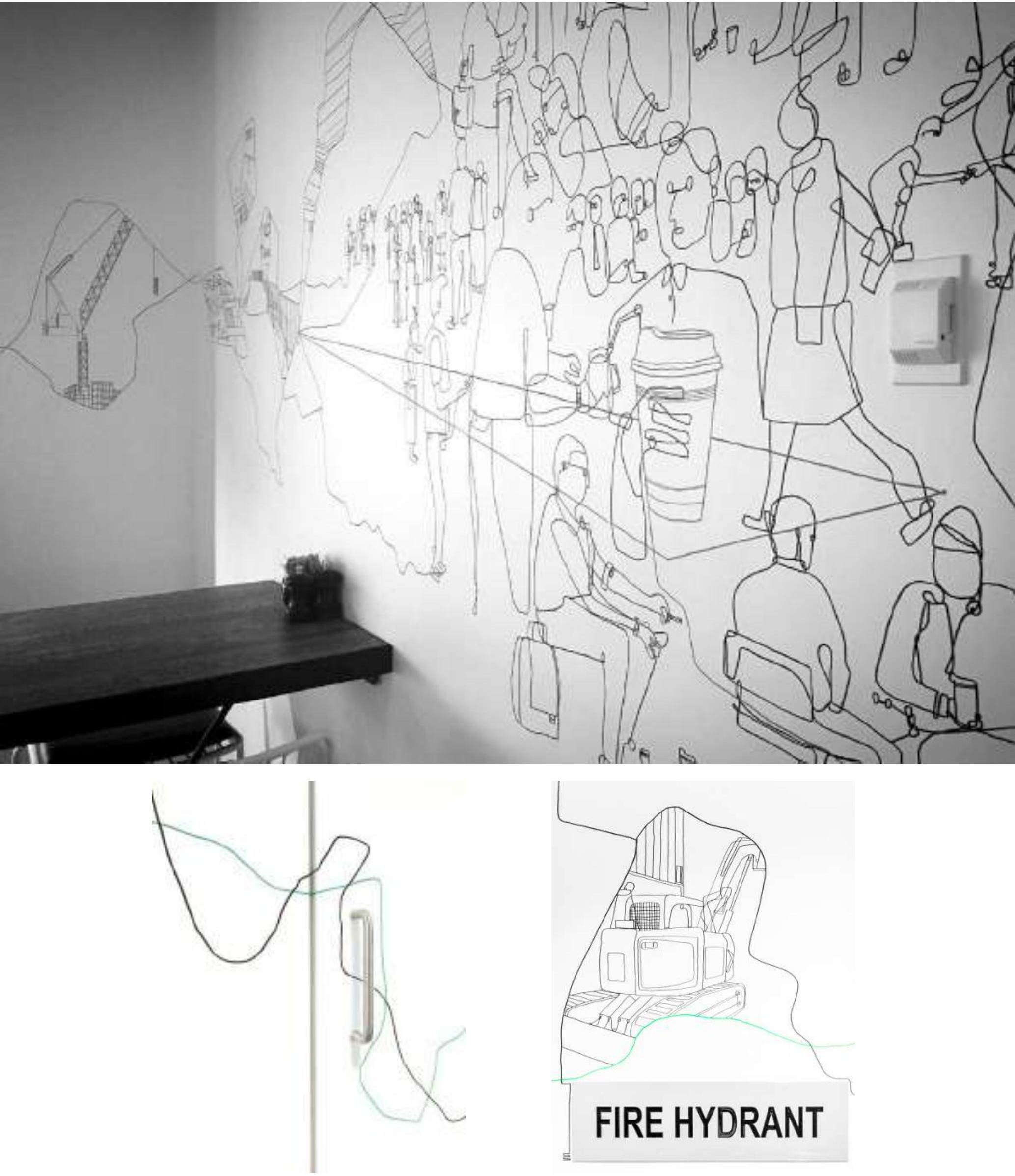

I 37 | The Journal of Public Space, 3 (2), 2018 | ISSN 2206-9658 


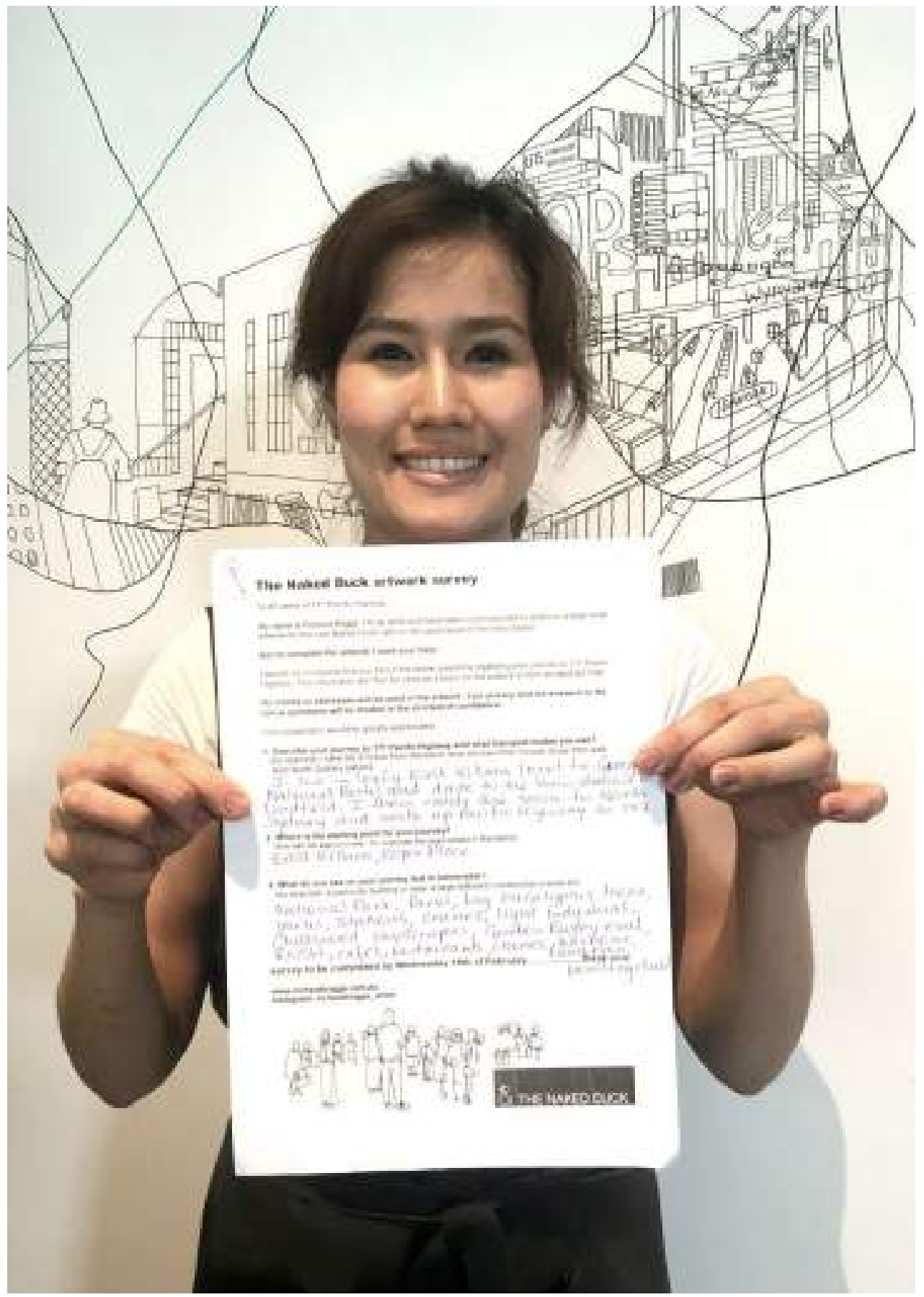




\section{Marrickville garage door} 2015

This public artwork on a private garage door in a laneway in Marrickville, Sydney was done as part a Council run initiative called the perfect match mural program. The aim of the program is that Council teams up with local residents, identifying areas where unwanted tagging is prominent. These walls, and in this case a garage door, are given to a range of local artists each year as 'canvases' which then become public art. This legalised and permanent art is usually respected by all and in many cases has been a successful program. This garage door was donated as a 'canvas' by a local resident, who like myself was interested in the demographic of the area which is home to over $5 \mathrm{I}$ different nationalities. Using data collection from the national census (2010), I mapped out each different nation in terms of the population in the local council area. This generated a population graphic, with the colours selected being a representation of each nation's flag. The longer the coloured line, the larger the population of that particular nation $(3 \mathrm{~mm}$ represented one person). These coloured bands, also spill over onto the brick work with a patterning that reflects the market gardens in the area. The linework over the top of the coloured bands tell the stories of the past industries of the area, such as steelworks, tram networks, potteries, and farming. This formed a dialogue between past and current, using two different graphical approaches. The holistic idea was that the garage door could be added to over time to frame any changes in demographic as each census is completed, so it becomes a live and ongoing representation of the cultural diversity of the area. The garage door after 4 years has not been tagged, whilst those without artwork on them have, proving the worth of the council run program.

\section{People born in Vietnam, 2011}

\section{Marrickville Council area}

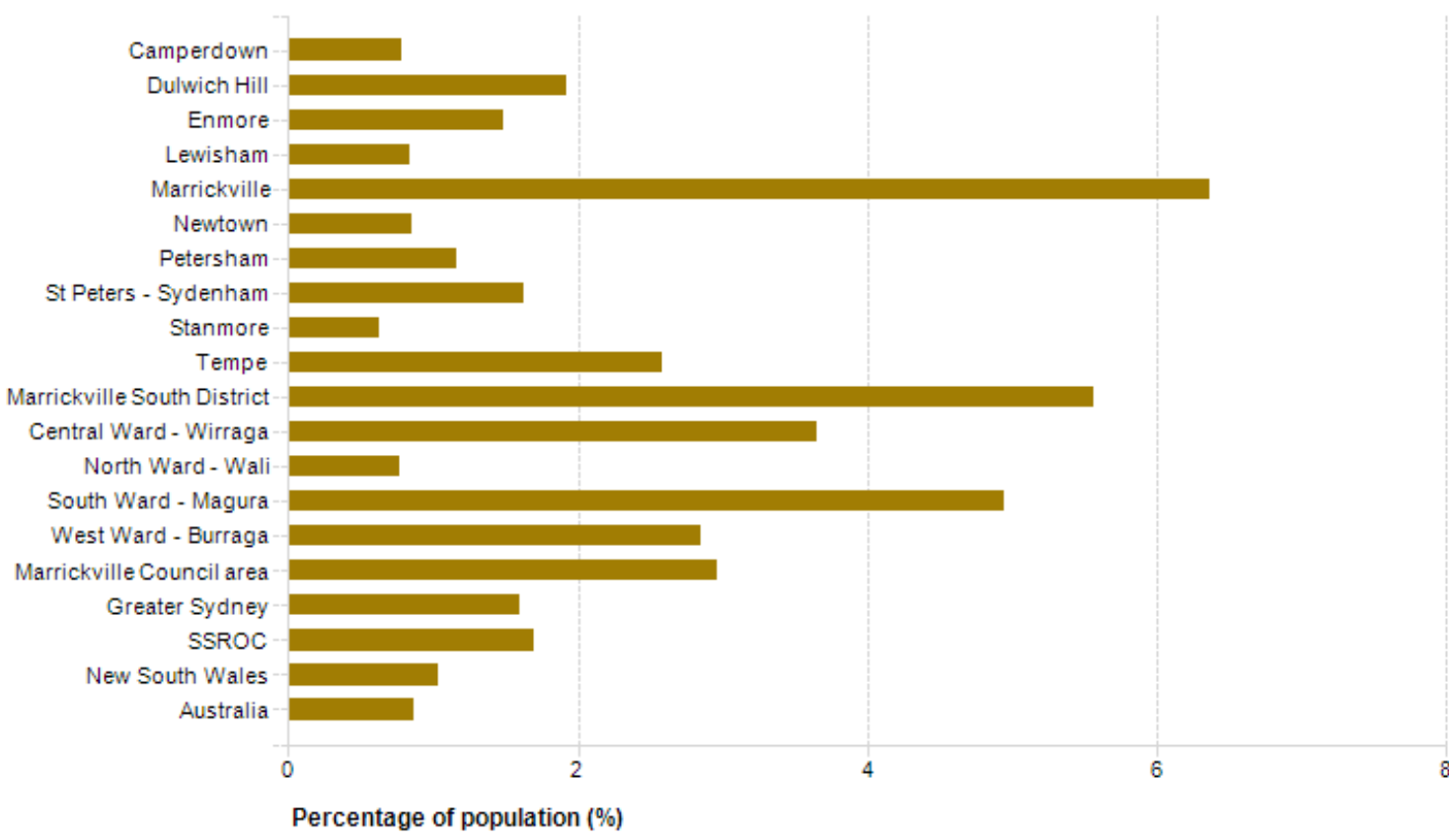



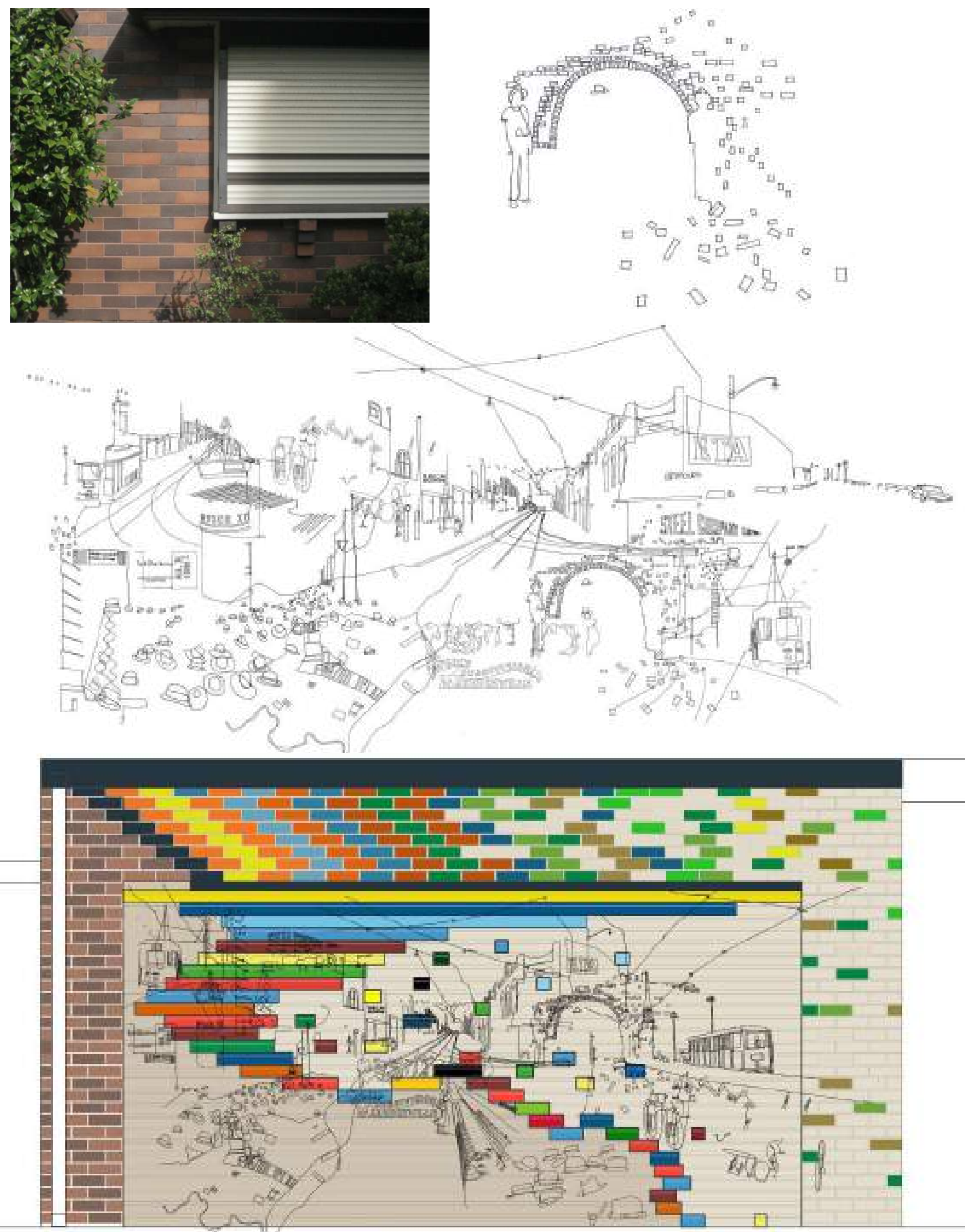

I40 | The Journal of Public Space, 3 (2), 2018 | ISSN 2206-9658

City Space Architecture / UN-Habitat 

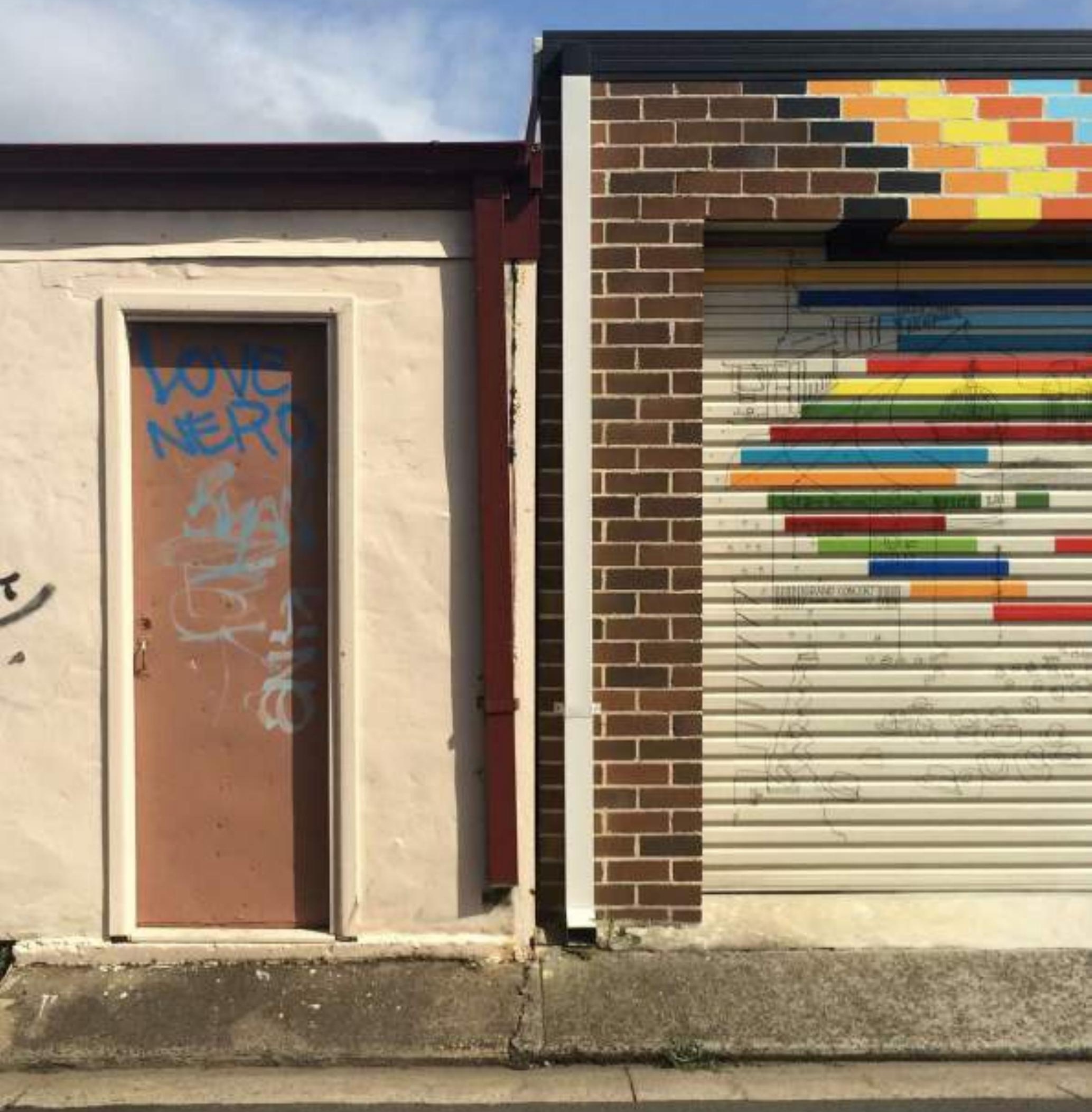

I4I | The Journal of Public Space, 3 (2), 2018 | ISSN 2206-9658 

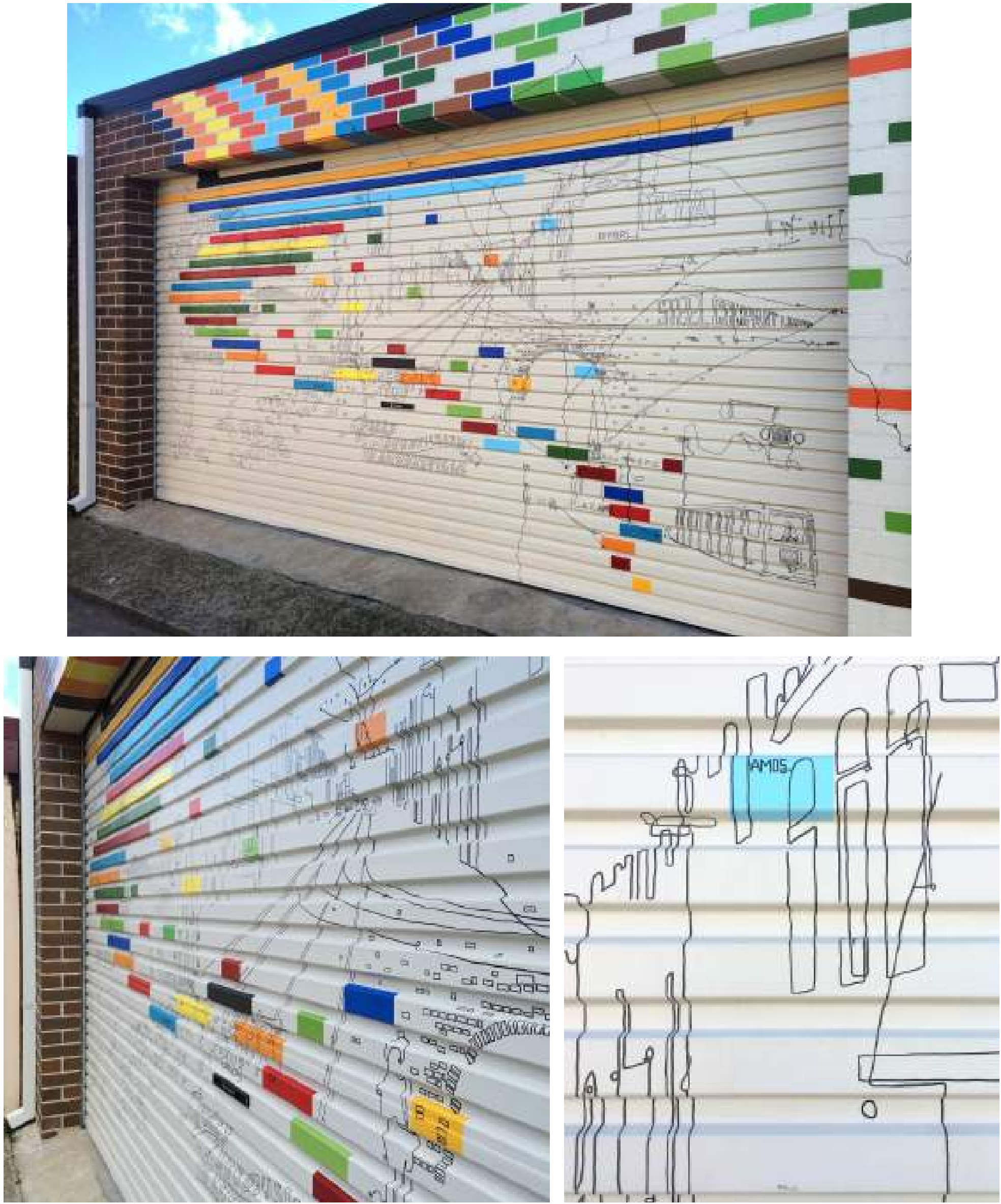

I42 | The Journal of Public Space, 3 (2), 2018 | ISSN 2206-9658

City Space Architecture / UN-Habitat 

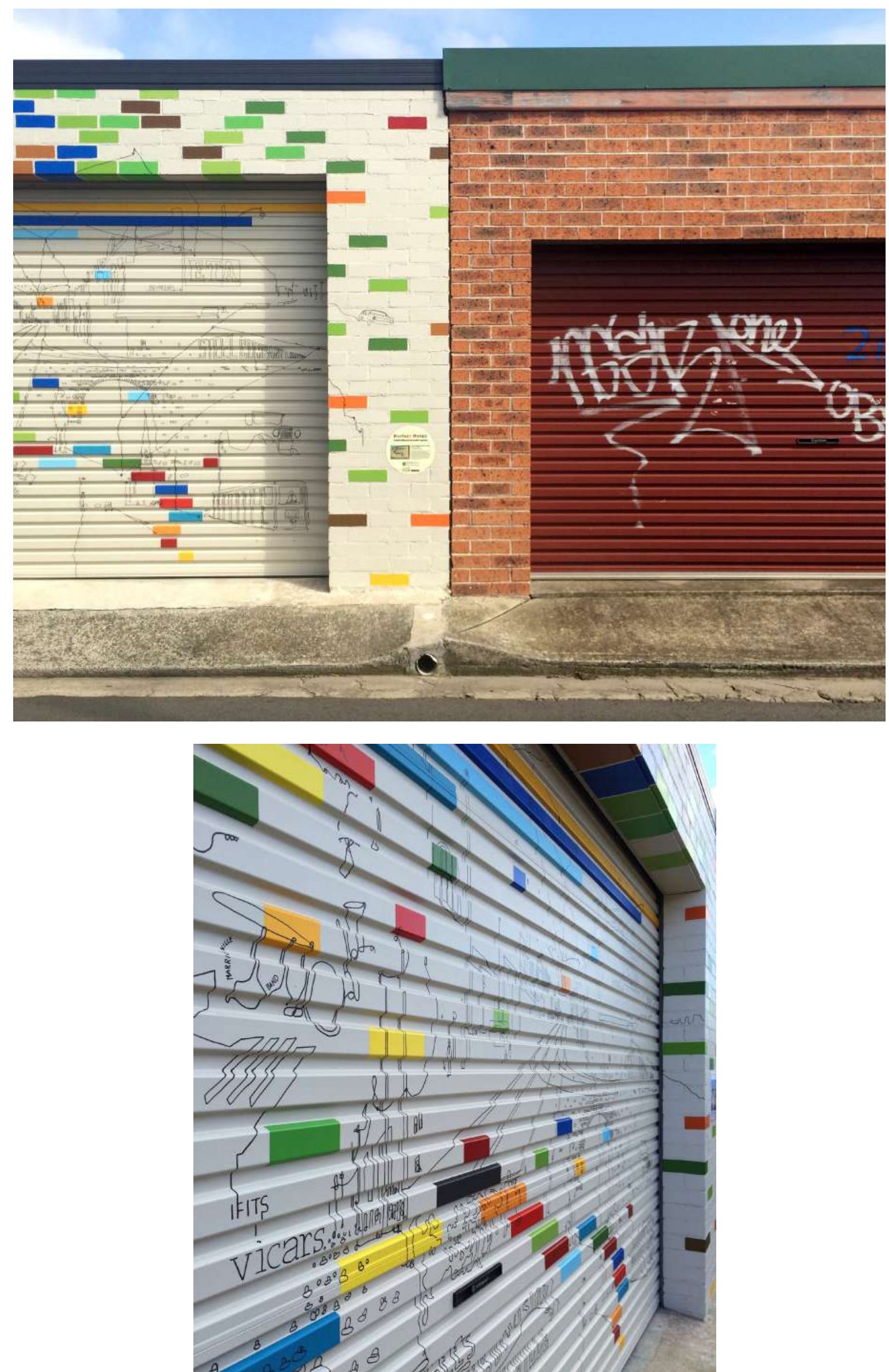

I43 | The Journal of Public Space, 3 (2), 2018 | ISSN 2206-9658 City Space Architecture / UN-Habitat 


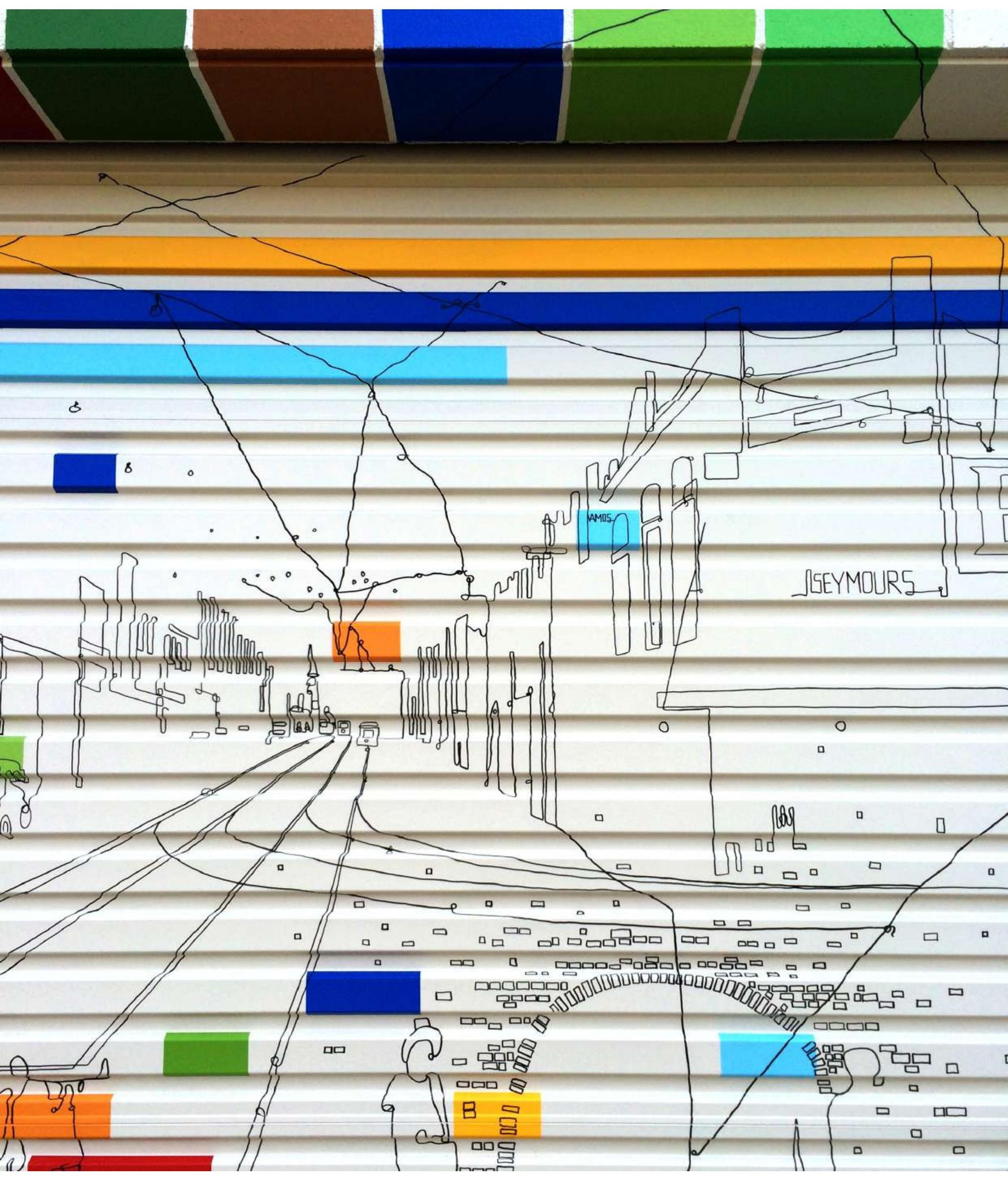

I44 | The Journal of Public Space, 3 (2), 2018 | ISSN 2206-9658

City Space Architecture / UN-Habitat 


\section{Elizabeth lane art incubator}

2017- ongoing

This is an ongoing project that, from a public space point of view, plays on the idea of surprise and intrigue with art located in unusual places. Elizabeth lane in Redfern in Sydney sits at the back of a residential and industrial streets, with many unwanted items discarded and left abandoned. Thinking about these objects, l'm interested to try to give them one last lease of life before they head to their final destination (usually a waste disposal unit) by drawing onto the surfaces. It also starts to talk about how in this modern-day society items are discarded with such ease as opposed to trying to repurpose and recycle.

The drawings on the items, which can be anything from microwave ovens, to chairs to suitcases, take on the form of patterns, lines, and words. The latter, borrowed from songs, relate to what's going on in the world both politically and socially, with the aim being if people stop to read the words they provide a message or ask a question related to world issues. All drawings on the items are done completely insitu, then left to their own devices. Sometimes they are gone within the hour, sometimes they remain for weeks. This laneway is also home to two other public art concepts I have; one being drawing on small timber tiles, that are left within the context. When taken out of the context, they provide a memory of where they once existed. The other experimental idea I have is using painter's tape as a medium to form simple line drawings. These tape drawings provide a temporary response to the immediate context through shapes and patterns. All these approaches are experimental, with the idea that the laneway acts as an art incubator for trying out different ideas, all of which aim to slow down the pace at which the people move through the laneway.

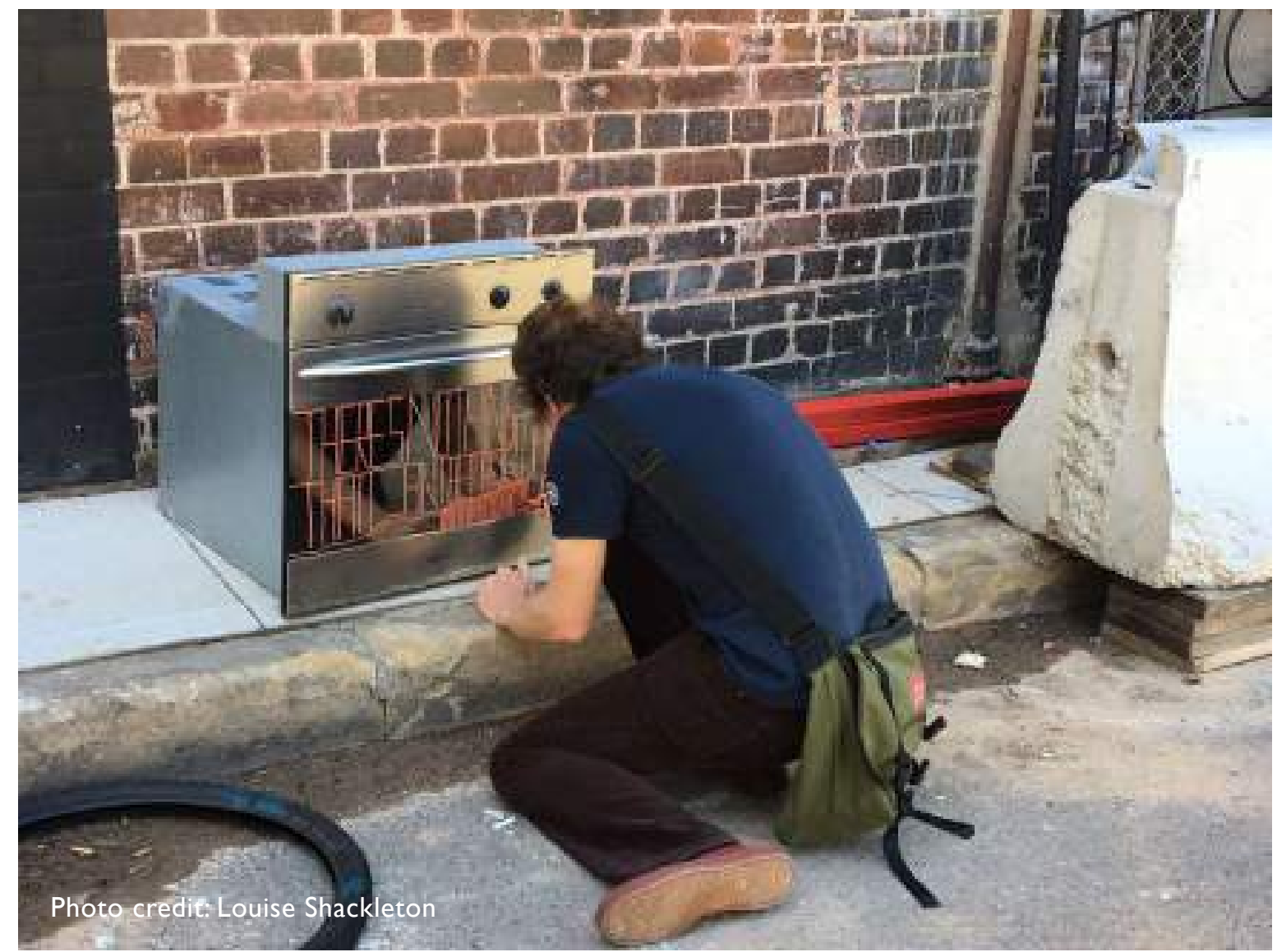

I45 | The Journal of Public Space, 3 (2), 2018 | ISSN 2206-9658 City Space Architecture / UN-Habitat 

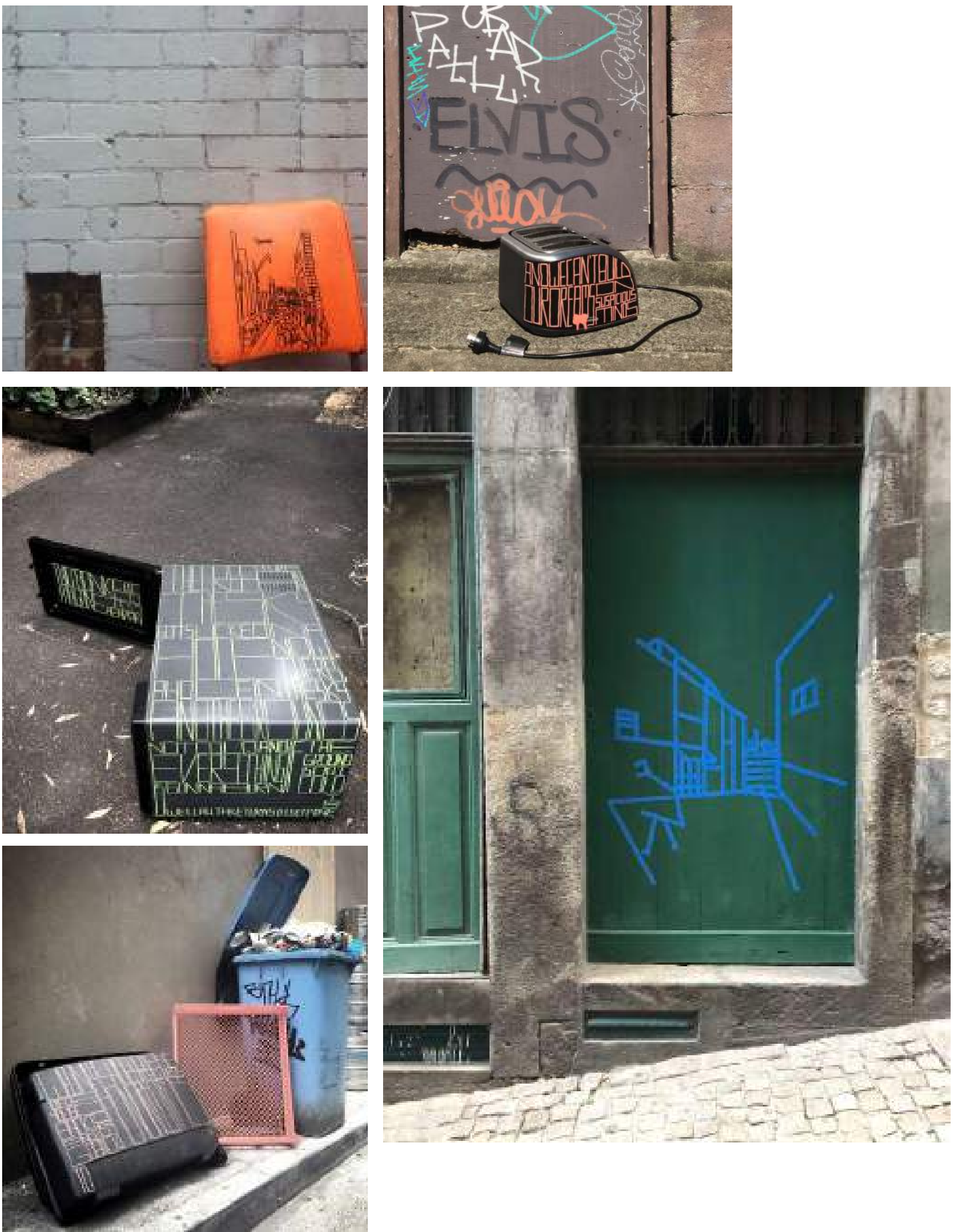

I46 | The Journal of Public Space, 3 (2), 2018 | ISSN 2206-9658

City Space Architecture / UN-Habitat 

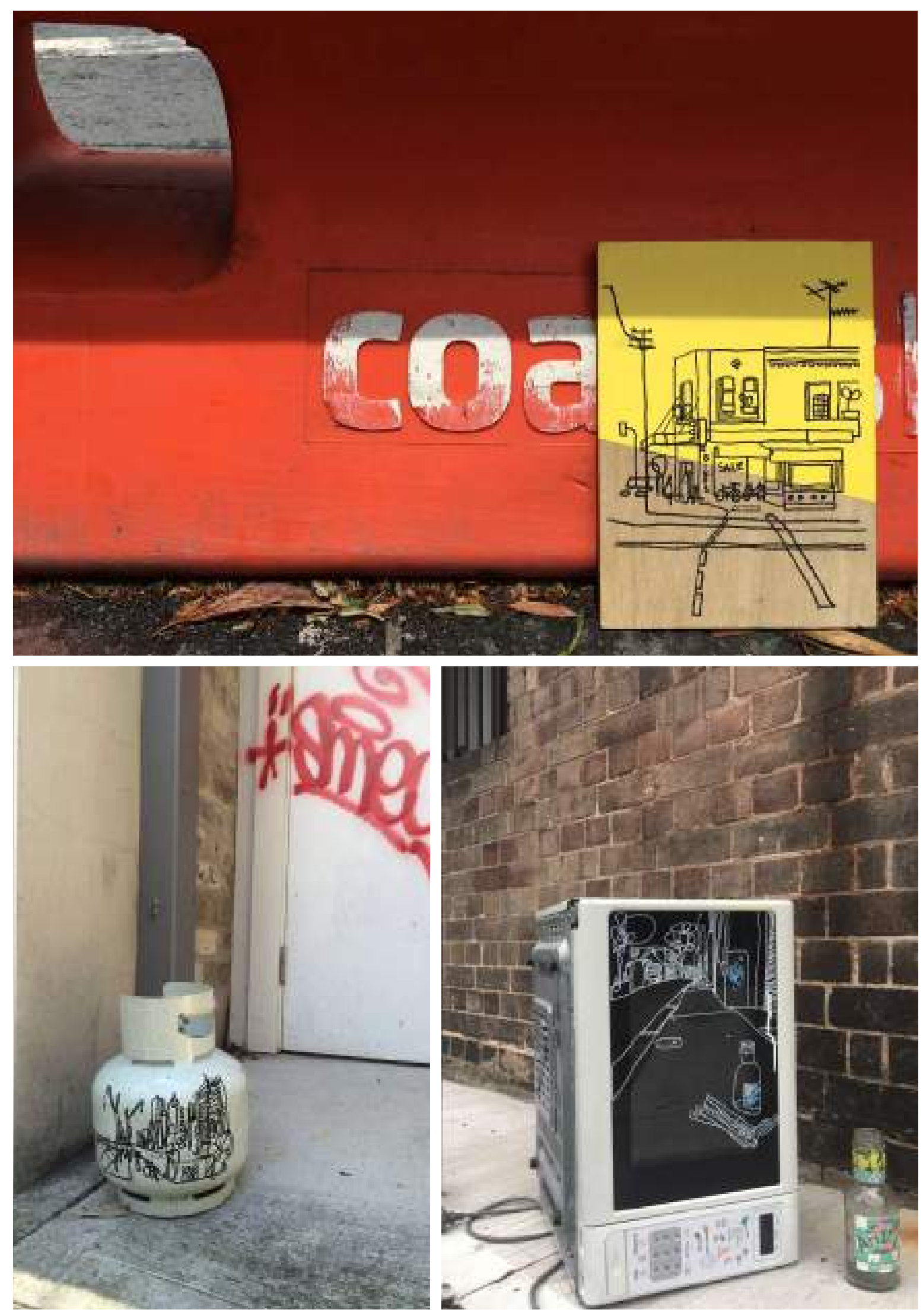

147 | The Journal of Public Space, 3 (2), 2018 | ISSN 2206-9658 


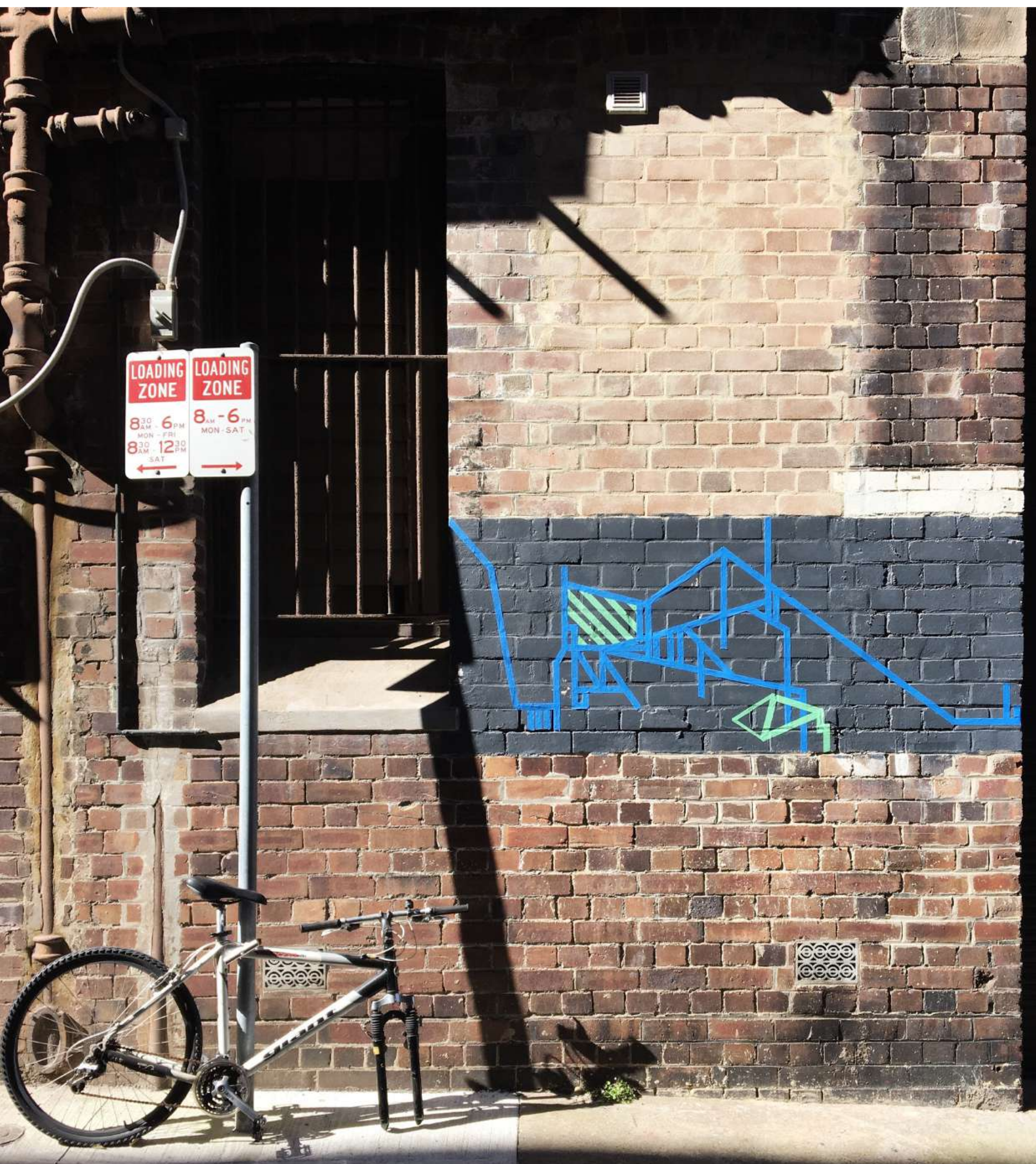


The Journal of Public Space

ISSN 2206-9658

2018 | Vol. 3 n. 2

https://www.journalpublicspace.org

\title{
A situated practice
}

Fiona Hillary

RMIT University, Australia

fiona.hillary@rmit.edu.au

\begin{abstract}
A situated practice explores one artist's approach to navigating the shifts and changes inherent in the public space of the post-industrial city and suburbs of Melbourne, Australia. Collaborative, ephemeral, site-specific, relational works in three specific sites; Station Pier in Port Melbourne, automated pedestrian crossings throughout the city, and at the Western Treatment Plant, the sewerage facility on the western edge of Melbourne's urban sprawl, explore everyday public sites to stake a claim for the imagination. Engaging with the work of critical theorists including Rosi Braidotti, Franco Bifo Berardi and Donna Haraway I am interested in how the abstraction of ordinary experiences and spaces allow artists and audience to co-constitute the possibility of something other, triggering fleeting transformative acts of imagination. Through this body of work, I am learning how to leave the marks of care for the future and 'stay with the trouble.' (Haraway, 2016, p.10).
\end{abstract}

Keywords: situated practice, public art, post-humanism, refrain, rhythm, resonance, everyday, borders, urban future

\section{To cite this article:}

Briggs, R. (2018). Using drawing as a tool to explore public space. The Journal of Public Space, 3(2), I49-166, DOI 10.3289|/jps.v3i2. III3

This article has been accepted for publication in The Journal of Public Space. Please see the Editorial Policies under the 'About' section of the journal website for further information.

This work is licensed under a Creative Commons Attribution - Non Commercial 4.0 International License https://creativecommons.org/licenses/by-nc/4.0/ 
Whatever increases your capacity to act and intervene in the world - intervene in the public sphere - for the love of the world.

(Braidotti, 20I4)

In a field of posthuman enquiry and experimentation, Rosi Braidotti, implores us to act, to question, to generate new collaborative ways of being in the world, generating work through situated practice; locating work in our own reality and experience. (Braidotti \& Hlavajova, 2017, p. I) Public practice is a discursive category of creative work that employs a broad lexicon of ideas, modes and materials to make culture in civic spaces. This evolving practice takes multiple forms and has long been recognized for its capacity to reflect, intervene, disrupt and ameliorate on and in place/space or relational forms of place/space. My interest in public practice is located between visual, performative and social practices. It lies in the capacity for creative public practice to explore how we vision the future and asks what can public practice do to intervene in our rehearsal of the future?

I am interested in Franco Bifo Berardi's ideas of rhythm, movement and refrain in his recent publication END: Phenomenology of the end he says:

The way a society, culture, or a person perceives time is also a model of truly temporal refrain, that is of particular rhythmic modulations that act as ways to access cosmic temporal becomings and attune to them.

The stuff that composes a refrain is essentially rhythm. Singular refrains can create a common space of resonance, and a new form emerges as a new rhythm. It is the new rhythm that makes it possible to see a new landscape.

(Berardi, 2015, p. 317)

Here I offer a journey through three temporal site-specific public works - Are You Here; Crossings; and $37^{\circ} 57^{\prime} 02.5^{\prime \prime} \mathrm{S} 144^{\circ} 38^{\prime} 02.0^{\prime \prime} \mathrm{E}$. Each work draws on the movements and rhythms of the space and creates a resonance in the everyday functioning of sites in an attempt to intervene in public space with the hope of visioning new landscapes.

Are You Here was a public/socially engaged work, co-created across the summer of 2015/16 with collaborator Benjamin Cittadini. For eight weeks in four shipping containers at Station Pier, we established a processing centre, processing people's journey from the present to the future. Station Pier is Melbourne's second biggest border entry port to Victoria, Australia after the Melbourne Airport. According to Victorian Ports Melbourne. 'operating for over 150 years, the pier has been important in almost every phase of Australia's history.

- In war and peace.

- Commemoration and celebration.

- Servicemen returning home.

- Migrants arriving from distant lands.

- Refugees arriving from war zones.' (Victorian Ports Melbourne, 2005)

The contemporary Station Pier ushers people from their cruise ships as a point of destination or as a tourist in transition from P \& O ships. At Station Pier the Spirit of Tasmania disembarks twice a day for Tasmania. The resident population of Port Melbourne has shifted significantly across time; originally home to the Boonwurrung people of the Kulin Nation, to a working class cohort servicing the port post colonization, to the present population of retirees and young professionals.

Are You Here 2016 consists of a suite of soundscapes, developed by my collaborator Benjamin Cittadini, that welcomed and farewelled the travellers, in part a reference to Brian Eno's ambient works for non-spaces (Eno, 1978). Within this soundscape we invited people to 
document their visit with a polaroid photo, taken in front of a 1970's styled vision of a future city, as a souvenir to take into the future. We created performative interventions, establishing a ritual farewell for the cruise ships from the present into the future. An immersive projection work, of the ocean the ships sailed on or the sky they sailed beneath, created a platform for spontaneous participatory performance. A neon sign flashed incoherently, you here are, here you are, are you here; gold tents constructed from foil safety blankets offered shelter from the wind and a video work documented the rituals of arrival and departure. A traffic management official working on loading cars on to the Spirit of Tasmania signaled to me to approach him. It seemed he had something he wanted to say-apprehensively expecting him to reveal we were in breach of some port legislation I approached - instead, as sweat dripped from his heat affected face, he thanked me for the soundscapes, they changed his normally intense day and he felt like they changed the mood of the people in the cars that lined up for a kilometer along the esplanade in the summer heat. Each day passers-by would ask what we were doing there, each day new ideas about our purpose were generated - for example the shipping containers and a near-by demolition site ignited people's interest in the potential of a re-development on the site, giving us the opportunity to engage in conversations about what that might look like. In the evenings, the projections created a performative framing for people who playfully explored their own presence in the glow of the projected works. As one family walked away with their souvenir family portrait, I heard the adult male say to his family - 'this means we'll be together in the future'.

Cittadini and I tended the works every day in non-descript uniforms - as non-descript kind of workers. Through this work we intervened in the rhythmic modulations of the site creating a form of social rupture that generated a temporary new resonance in the everyday function of Station Pier.

Are You Here extended a range of process-based and participatory public sphere strategies previously examined in Crossings (2015), a collaboration with Benjamin Cittadini, Ceri Hann and Shanti Sumartojo. Crossings explored more personally located borders within the legislated landscape of the city. A repetitive, ritualised action by four associates; three artists and a cultural geographer, again in non-descript uniforms, collectively occupied a series of automated pedestrian crossings throughout the city of Melbourne and its surrounding suburbs. A generative/iterative series of actions worked by both locating ourselves in, and interrogating, the physical site; experiencing social and legislative borders that created dialogue between us as practitioners and with the everyday users of the pedestrian crossings we interrogated. The rhythm of the street chimed into order as the 'Audio Tactile Pedestrian Detectors' sounded their commanding tones and set a pace, our presence played with this order and the expectations of the people entering to perform their daily journeys through the city.

In one iteration, we were joined by other people mimicking our repeated actions. I stood still waiting for the lights to change, a man looked me up and down, as the lights changed I noticed him looking at his own attire, it was as if he was checking to see how we fitted together, if in fact we did. To some we were invisible, there was a sense the unseeing pedestrian would work hard not to see us. One woman couldn't work out how to navigate her pathway around me with her suitcase of belongings, she expressed her exasperation as if $\mathrm{I}$, in my non-descript uniform had no right to be there - the nondescript uniform seemed to offer a sense of authority for people to rub up against. There were personal borders being pulled close and tight as pedestrians performed to the beat of the legislative borders of the automated pedestrian crossing.

'Are you Here' and 'Crossings' are examples of site specific works grounded in the reality of their location: geographical, psychological, political and philosophical borders as they intersect with individual and collective movement. We created temporary incursions into everyday 
contexts impacting the social imaginaries at play in each location. Representation is critical to Braidotti's thinking in the 'First Supper Symposium' she asks if 'we are often represented as the 'subjects of catastrophe' what can the imagination do to cut through or challenge this representation?' (Braidotti, 2014) While Braidotti is skeptical of dystopian frameworks she is clear that 'the imagination is not utopian, but rather transformative and inspirational. Hope is a vote of confidence in the future...'(Braidotti, 20I I, p. 14) She appeals to her audience to work toward 'horizons of hope' to navigate the future.

Simon Sheikh quotes Walter Benjamin in The Arcades Project when he postulates, "the present...already stands to the recent past as the awakening stands to the dream...Every epoch, in fact, not only dreams the one to follow but in this dreaming, precipitates its awakening" (Sheikh, 20 I , p. 165). I am interested in the potential limitations of framing the imagination and framing the future. Like Braidotti, Sheikh calls us to invoke our radical imagination 'which is where art has a crucial role to play in providing vectors of the possible, posing questions of possibility and vicinity, as well as making invisible limits visible within the ontology of the horizon' (Sheikh, 20II, p. 164).

The public work $37^{\circ} 57^{\prime} 02.5^{\prime \prime S} 144^{\circ} 38^{\prime} 02.0^{\prime \prime} \mathrm{E} 2017$ was located in the vast horizon of the Western Treatment Plant (WTP), where people have for generations shifted between the present and the future. A durational ensemble performance for the future was proposed as an act of recuperation. In the tradition of Edward Said and Daniel Barenboim's orchestra West-Eastern Divan (1999) the work is intended to trigger dialogue, between artists, audience and site.

$37^{\circ} 57^{\prime} 02.5^{\prime \prime} \mathrm{S} 144^{\circ} 38^{\prime} 02.0^{\prime \prime} \mathrm{E}$ (2017) was part of Treatment: Flightlines curated by Cameron Bishop and David Cross as an investigative creative project to creatively explore the Western Treatment Plant (WTP) in Melbourne's western districts, thirty-nine kilometers from Melbourne's Central Business District. Utilising the WTP as a test site of practice began as a journey to explore a rapidly transitioning landscape on the edge of Melbourne's urban sprawl as post-industrial sites are being remunerated and transformed into the contemporary urban Australian dream, a house on a quarter acre block. Werribee is renown historically and in the present as a test site in many ways.

The work of the Western Treatment Plant, through experimentation and research has seen incredible contributions to advanced cutting-edge human waste treatment processes critical in sustaining our rapidly expanding urban populations, Melbourne Water treats over 320,000,000 litres of sewerage each year through the Eastern and Western Treatment Plant (Water, 2018b) The development of Anaerobic lagoons at WTP, covered in plastic tarps has not only reduced greenhouse gas emissions and the aroma of the lagoons by capturing the gases, but provides gas that is able to power engines that generate electricity (Water, 2018c). Within the Western treatment plant lies the small abandoned township of Cocoroc. Cocoroc was built in 1894 to house the workers of the Metropolitan Sewerage Farm. The township grew across time - houses, a community swimming pool, a town hall and football ground, tennis courts, schools and a post office. By the 1970s Cocoroc was home to a population of 500. In the 70s it was too expensive for the Melbourne and Metropolitan Board of works to maintain and residents were effectively relocated into the suburb of Werribee. (Water, 2018a) What remains of the township now, and is imminently about to change is the Water Tower, the swimming pools, a football oval and change rooms and a community hall. The Water Tower at Cocoroc was built in another century, originally in East Melbourne to deal with the rapid expansion of the city, Melbourne, providing clean water during cholera and typhoid outbreaks. It was moved and rebuilt in Cocoroc in 1892 - the official record says it provided a back-up water supply to Cocoroc until 1924, but word on the ground is that it was never really used for this purpose - there is something interesting in its form as an empty icon.

I52 | The Journal of Public Space, 3(2), 2018 | ISSN 2206-9658

City Space Architecture / UN-Habitat 
There is something potent in the generative progressive nature of durational performance on site, creating and exploring the intervals, interstices between the post-industrial landscape looking toward a posthuman landscape. I am interested in assemblages that explore alternative narratives/stories of site that breathe with the space. There is something ceremonial - in the singular and collective act.

A call out via social media invited respondents to submit a song that reminded them of the future, or that they would take into the future. Eighty nine songs later, with one original composition from one of the staff of the WTP, I extended an invitation to four electric guitarists; Billy Miller, Penny Ikinger, Sorcha Wilcox and Benjamin Cittadini to respond to the set list. Each guitarist chose four songs and through the seven hour performances they became abstracted, they became something else - a collaborative statement about the present, the time spent in the water tower, the resonance of the past and present reaching out across the landscape enveloping all that lay in its wake. The work claimed the space in concert with the occupants of the site for those two seven hour performances.

I am interested in the multiplicity of readings of our times - triggering ruptures in affect to generate some kind of resonance in an attempt to create spaces or moments for 'recuperation'. (Haraway, 2016) Creating a space - a moment - where affect shifts constituting an encounter with sound, light and the resonance of the space. Sometimes the sound is too loud, too abstract, sometimes there is a familiarity in the sound - a soothing call providing a moment to consider how we 'stay with the trouble' when listening to the lone strains of the guitar through a seven hour performance. (Haraway, 2016)

As the community of Cocoroc was being moved to Werribee, rock and roll was taking centre stage in Australian culture - Countdown, a popular weekly Australian music television show, never came to Cocoroc as there were no TVs. This work marked that missing period in time. This was a durational sound performance for the future - a moment in time that created encounter while tearing an affective schism in time and the landscape.

Affect is born in in-between-ness and resides as accumulative beside-ness.

(Seigworth and Gregg, 2010, p.3)

Drawing on Louis Helbig's aerial photography of the site, neon configurations were constructed from recycled lengths of neon, reflecting the purpose of WTP in recycling our waste. Electric guitars and neon are both reliant on vibration and reverberation, as the hours passed and a smokey haze filled the space, like the sound outside the neon floated in the void. The empty water tank amplified abstracted strains of PJ Harvey's We Float, the Knightrider Theme, Gary Newman's Cars and Helen Reddy's I am woman. The landscape was enveloped in sound, an hourly refrain that repeatedly filled the spaces in between, the spaces of becoming, a call and response almost between a human yearning and other non-human occupants of the site.

The refrain of the electric guitars could be felt through my feet, vibrating through the core of my physical being. The coloured glow of the neon reflected in the faces of the audience. 'It's like a dreamscape' one man shared with me, yelling into my ear to be heard above the guitarist. The strains of the music amplified across the site, one woman later told me she didn't realise she could enter the water tower - she thought the enveloping sound that resonated across the site was the artwork. As the abstracted strains of Somewhere Over the Rainbow rung out a woman approached me, tears brimming in her eyes, she said 'thankyou' and left the work.

Through my practice I am not tracing the world. Rather I am exploring the traces of the world through repetition and refrain that allow us to stay in the moment or usher us into the future. Inspired by Haraway to engage in acts of worlding (Haraway, 2016), as the urban 
landscape morphs around us - urbanization spreading and encroaching - reterritorializing public space, I stake a claim for the imagination - situated in the present, drawing on the past and creatively resonating us into the future.

\section{References}

Barenboim, D. \& Said, E. (1999) West-Eastern Divan Orchestra, Spain.

Braidotti, R. (20II). Nomadic subjects : embodiment and sexual difference in contemporary feminist theory: New York : Columbia University Press, c201 I. 2nd ed.

Braidotti, R. (2014). The First Supper Symposium. Paper presented at the The First Supper Symposium.

Braidotti, R. \& Hlavajova, M. (2018). Posthuman Glossary: London: Bloomsbury Academic.

Berardi, F. B. (20I5). AND: Phenomenology of the End. South Pasadena CA: Semiotext(e).

Cornell, D. S., Stephen D. (2017). What Has Happened to the Public Imagination, and Why? 2 Ist Century Global Dynamics, 10(19).

Eno, B. (1978) Ambient I: Music for Airports, Polydor Records.

Seigworth, G. J. \& Gregg, M. (20I0). The Affect theory reader: Durham, NC : Duke University

Press.

Haraway, D. J. (2016). Staying with the trouble : making kin in the chthulucene. Durham: Duke University Press, 2016. ISBN: 978- 0-8223-6224-I.

Mendieta, E. (2010). Postcolonialism, postorientalism, postoccidentalism: the past that never went away and the future that never arrived. In T. S. May, A.D. (Ed.), Emerging Trends in Continental Philosophy (Pp. 149 - 172): Acumen.

Sheikh, S. (20I I). Vectors of the Possible: Art between spaces of experience and horizons of expectations. In S. S. J. W. Maria Hlavajova (Ed.), On Horizons: A Critical Reader in Contemporary Art (pp. 162-166). Utrecht: BAK.

Victorian Ports Melbourne. 2005. Station Pier History. [Online] Available at: http://www.vicports.vic.gov.au/about-us/port-history/Pages/station-pier-history.aspx [Accessed 10 July 20I8]

Water, M. (2018c). Western Treatment Plant. Retrieved from https://www.melbournewater.com.au/community-and-education/about-ourwater/sewerage/western-treatment-plant

Fiona Hillary is a lecturer and Industry Fellow in the Master of Arts - Art in Public Space at the School of Art, RMIT University, Australia. Fiona curates the Urban Laboratory for RMIT University's Contemporary Art and Social Transformation CAST research group. The Urban Laboratory uses live test sites of practice to explore urban contexts engaging art practices in a research and project delivery model in partnership with local government. She is a practicing public artist, collaborating on a range of temporary and permanent investigative projects. Her most recent work $37^{\circ} 57^{\prime} 02.5^{\prime \prime} \mathrm{S}$ $144^{\circ} 38^{\prime} 02.0^{\prime \prime} E$ marks the beginning of a creative cartography for the future. Fiona's research interests are in collaborative practice, the use of socially-engaged art practice as research methodology in public spaces with a specific focus on temporary installations. Fiona is a PhD Candidate at Deakin University exploring the role of public practice in reimaging futures. With Shanti Sumartojo she co-authored the paper Empty-Nursery Blue: On atmosphere, meaning and methodology in Melbourne street art published in Public Art Dialogue (20I4: 4: 2 :20I-220). 


\section{Are You Here}

2015-16

Are You Here was a public/socially engaged work, co-created with collaborator Benjamin Cittadini. For eight weeks in four shipping containers at Station Pier, we established a processing centre, processing people's journey from the present to the future.

Station Pier is Melbourne's second biggest border entry port to Victoria, Australia after the Melbourne Airport.

Are You Here 2016 consists of a suite of soundscapes, developed by my collaborator Benjamin Cittadini, that welcomed and farewelled the travellers, in part a reference to Brian Eno's ambient works for non-spaces. Within this soundscape we invited people to document their visit with a polaroid photo, taken in front of a 1970's styled vision of a future city, as a souvenir to take into the future. We created performative interventions, establishing a ritual farewell for the cruise ships from the present into the future.

An immersive projection work, of the ocean the ships sailed on or the sky they sailed beneath, created a platform for spontaneous participatory performance. A neon sign flashed incoherently, you here are, here you are, are you here; gold tents constructed from foil safety blankets offered shelter from the wind and a video work documented the rituals of arrival and departure. 

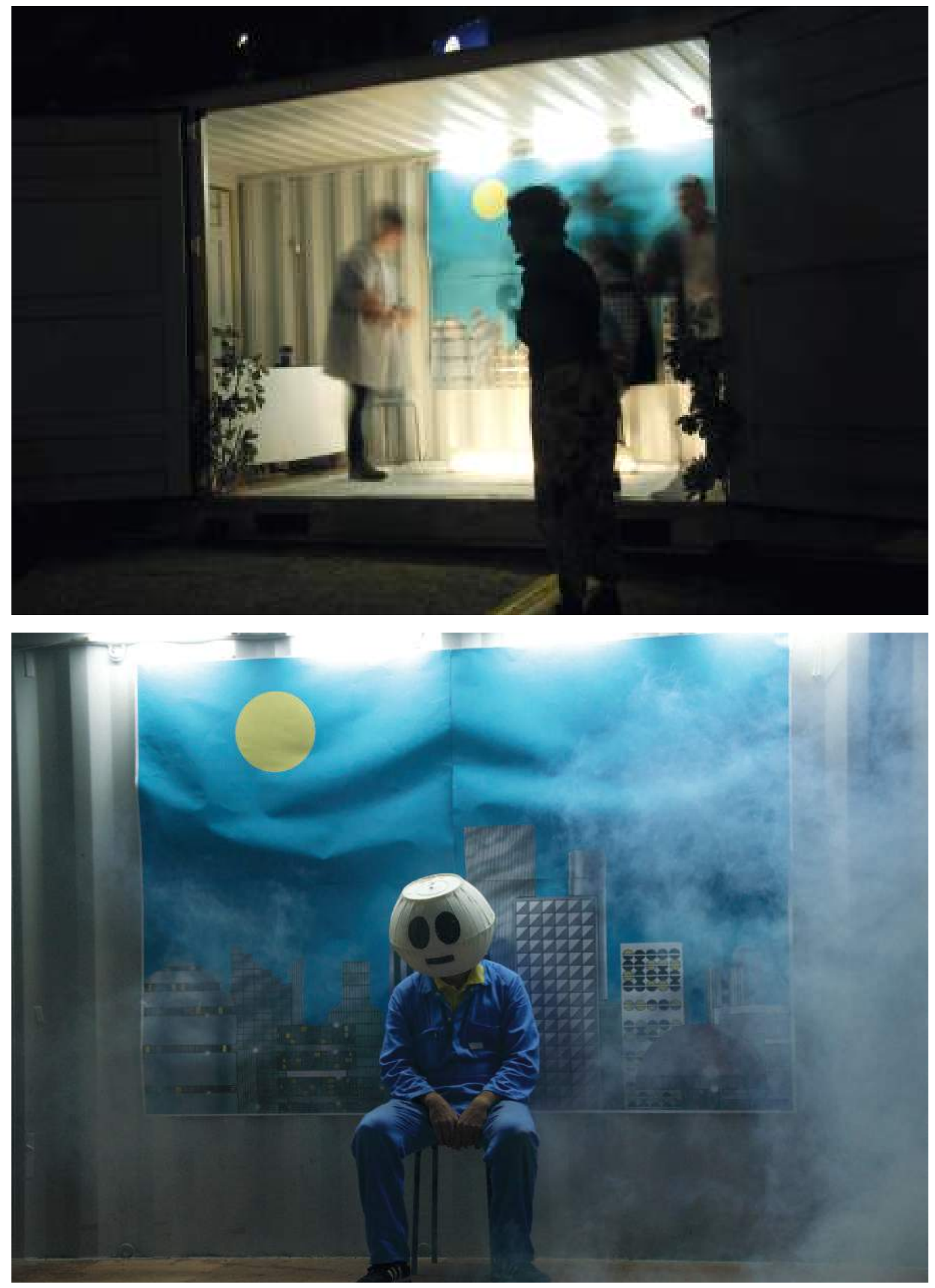

I56 | The Journal of Public Space, 3 (2), 2018 | ISSN 2206-9658

City Space Architecture / UN-Habitat 

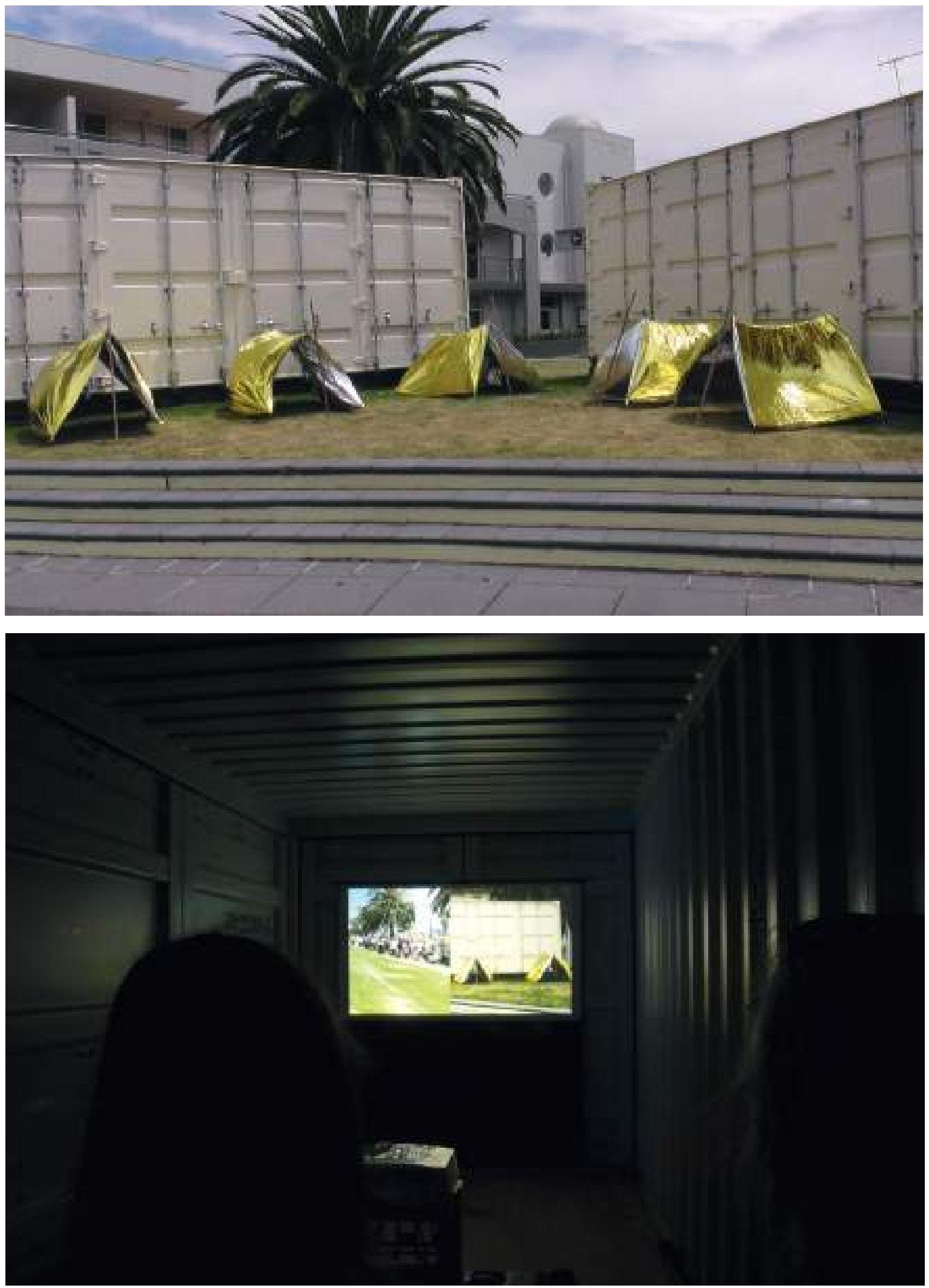

I57 | The Journal of Public Space, 3 (2), 2018 | ISSN 2206-9658 
Using drawing as a tool to explore public space

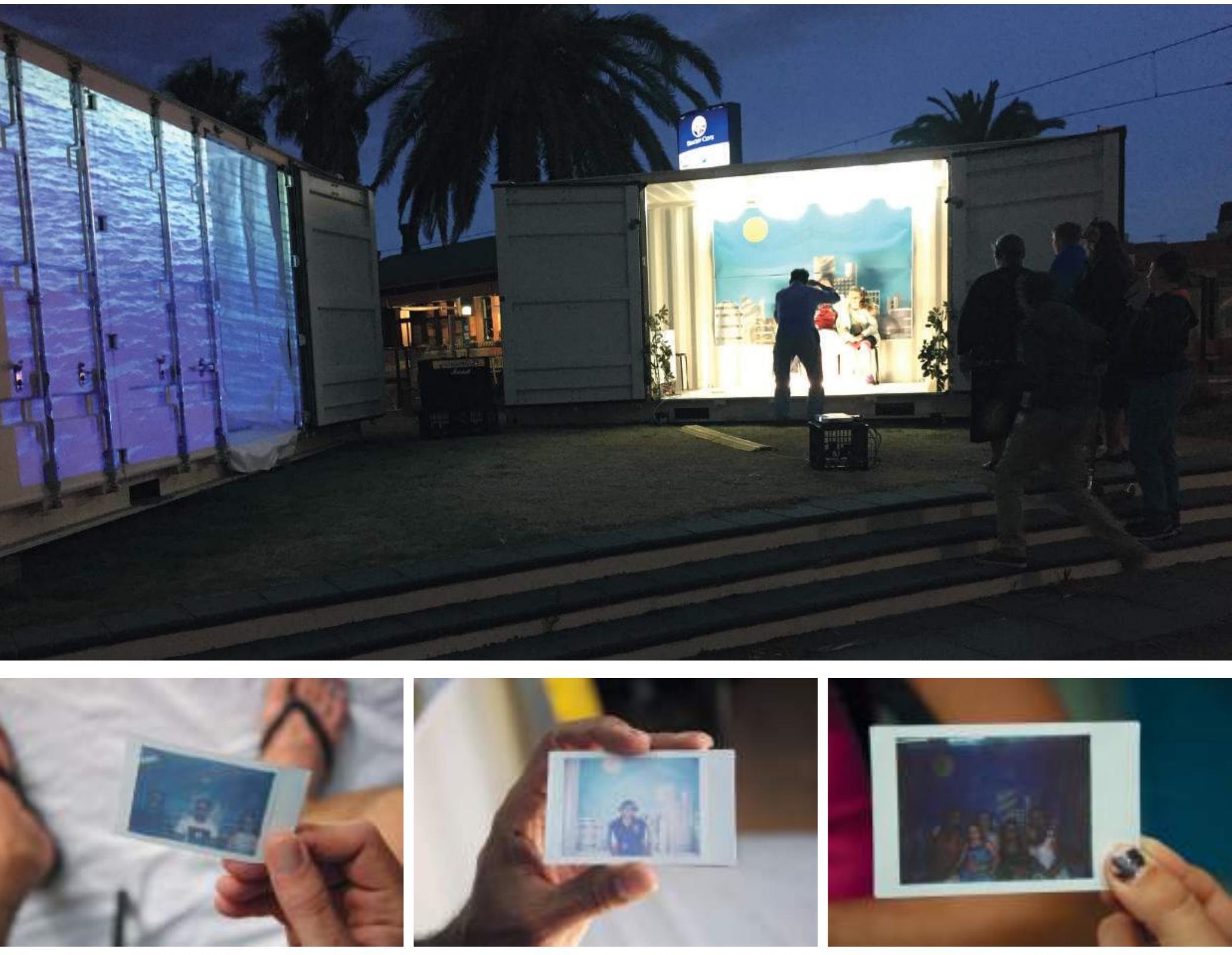

I58 | The Journal of Public Space, 3 (2), 2018 | ISSN 2206-9658

City Space Architecture / UN-Habitat 


\section{Crossings}

2015

Crossings was a collaboration with Benjamin Cittadini, Ceri Hann and Shanti Sumartojo. It explored more personally located borders within the legislated landscape of the city. A repetitive, ritualised action by four associates; three artists and a cultural geographer, again in non-descript uniforms, collectively occupied a series of automated pedestrian crossings throughout the city of Melbourne and its surrounding suburbs.

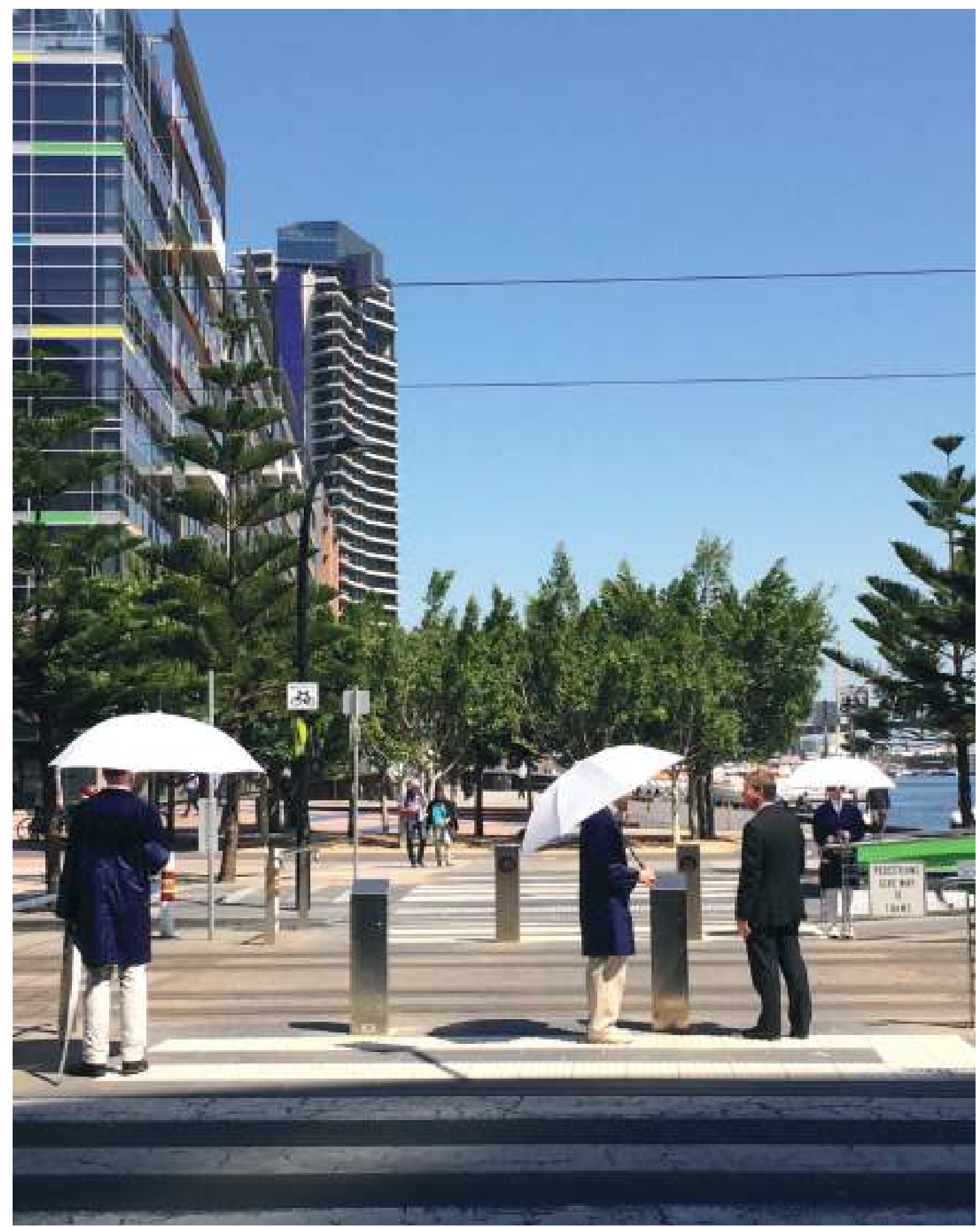

I59| The Journal of Public Space, 3 (2), 2018 | ISSN 2206-9658 City Space Architecture / UN-Habitat 
A generative/iterative series of actions worked by both locating ourselves in, and interrogating, the physical site; experiencing social and legislative borders that created dialogue between us as practitioners and with the everyday users of the pedestrian crossings we interrogated. The rhythm of the street chimed into order as the 'Audio Tactile Pedestrian Detectors' sounded their commanding tones and set a pace, our presence played with this order and the expectations of the people entering to perform their daily journeys through the city.
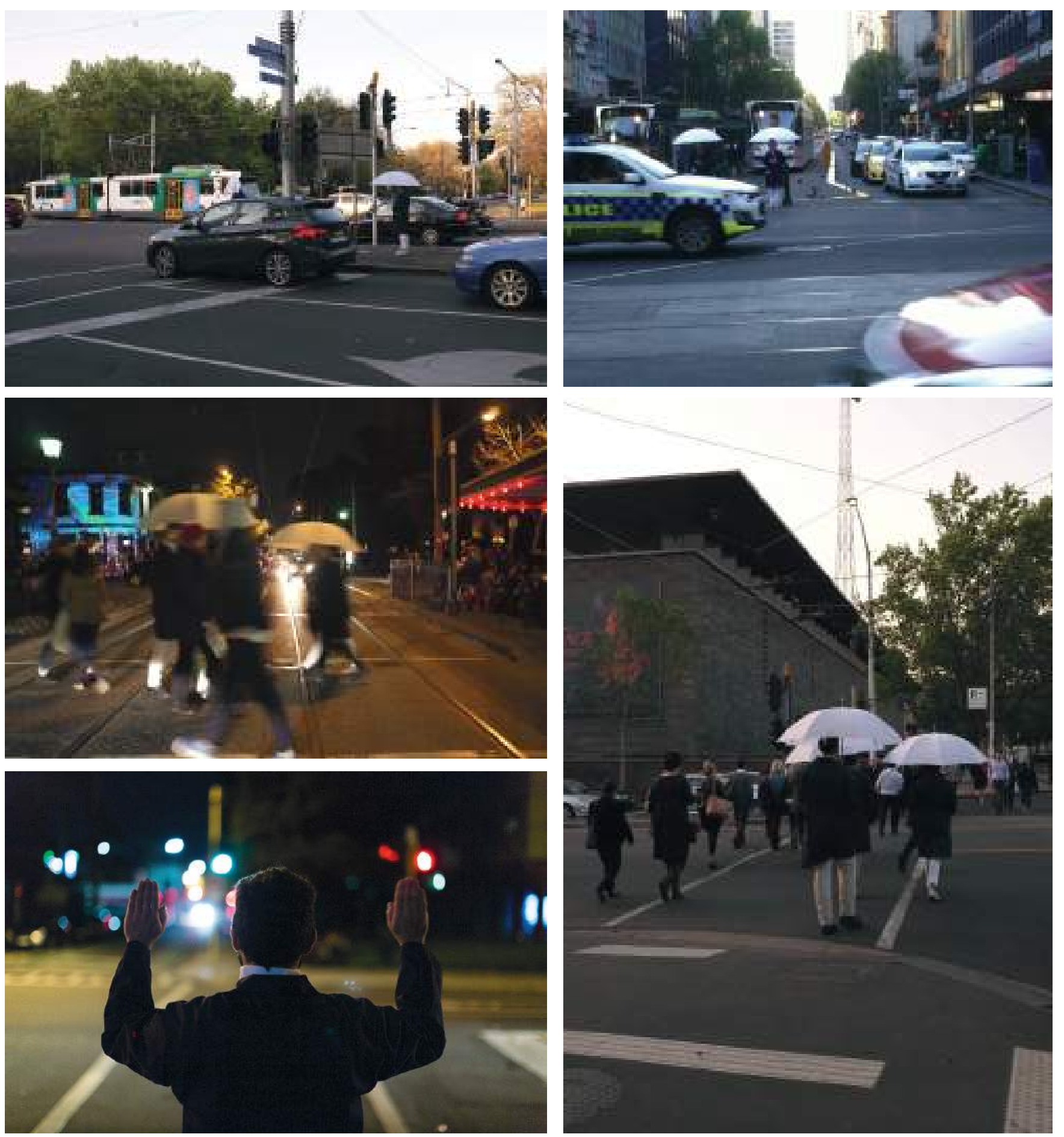

160 | The Journal of Public Space, 3 (2), 2018 | ISSN 2206-9658

City Space Architecture / UN-Habitat 

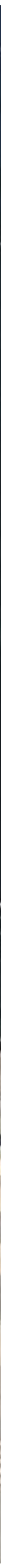

162 The Journal of Public Space, 3 (2), 2018 | ISSN 2206-9658

City Space Architecture / UN-Habitat 


\section{7'02.5'S I 44³8'02.0'E 2017}

\section{7}

The public work $37^{\circ} 57^{\prime} 02.5^{\prime \prime} S 144^{\circ} 38^{\prime} 02.0^{\prime \prime} \mathrm{E} 2017$ was located in the vast horizon of the Western Treatment Plant (WTP), where people have for generations shifted between the present and the future.A durational ensemble performance for the future was proposed as an act of recuperation. In the tradition of Edward Said and Daniel Barenboim's orchestra West-Eastern Divan (1999) the work is intended to trigger dialogue, between artists, audience and site.

$37^{\circ} 57^{\prime} 02.5^{\prime \prime} \mathrm{S} 144^{\circ} 38^{\prime} 02.0^{\prime \prime} \mathrm{E}$ was part of Treatment: Flightlines curated by Cameron Bishop and David Cross as an investigative creative project to creatively explore the Western Treatment Plant (WTP) in Melbourne's western districts, thirty-nine kilometers from Melbourne's Central Business District. Utilising the WTP as a test site of practice began as a journey to explore a rapidly transitioning landscape on the edge of Melbourne's urban sprawl as post-industrial sites are being remunerated and transformed into the contemporary urban Australian dream, a house on a quarter acre block. Werribee is renown historically and in the present as a test site in many ways.

Within the Western treatment plant lies the small abandoned township of Cocoroc. The township grew across time - houses, a community swimming pool, a town hall and football ground, tennis courts, schools and a post office. By the 1970s Cocoroc was home to a population of 500. In the 70s it was too expensive for the Melbourne and Metropolitan Board of works to maintain and residents were effectively relocated into the suburb of Werribee. What remains of the township now, and is imminently about to change is the Water Tower, the swimming pools, a football oval and change rooms and a community hall.

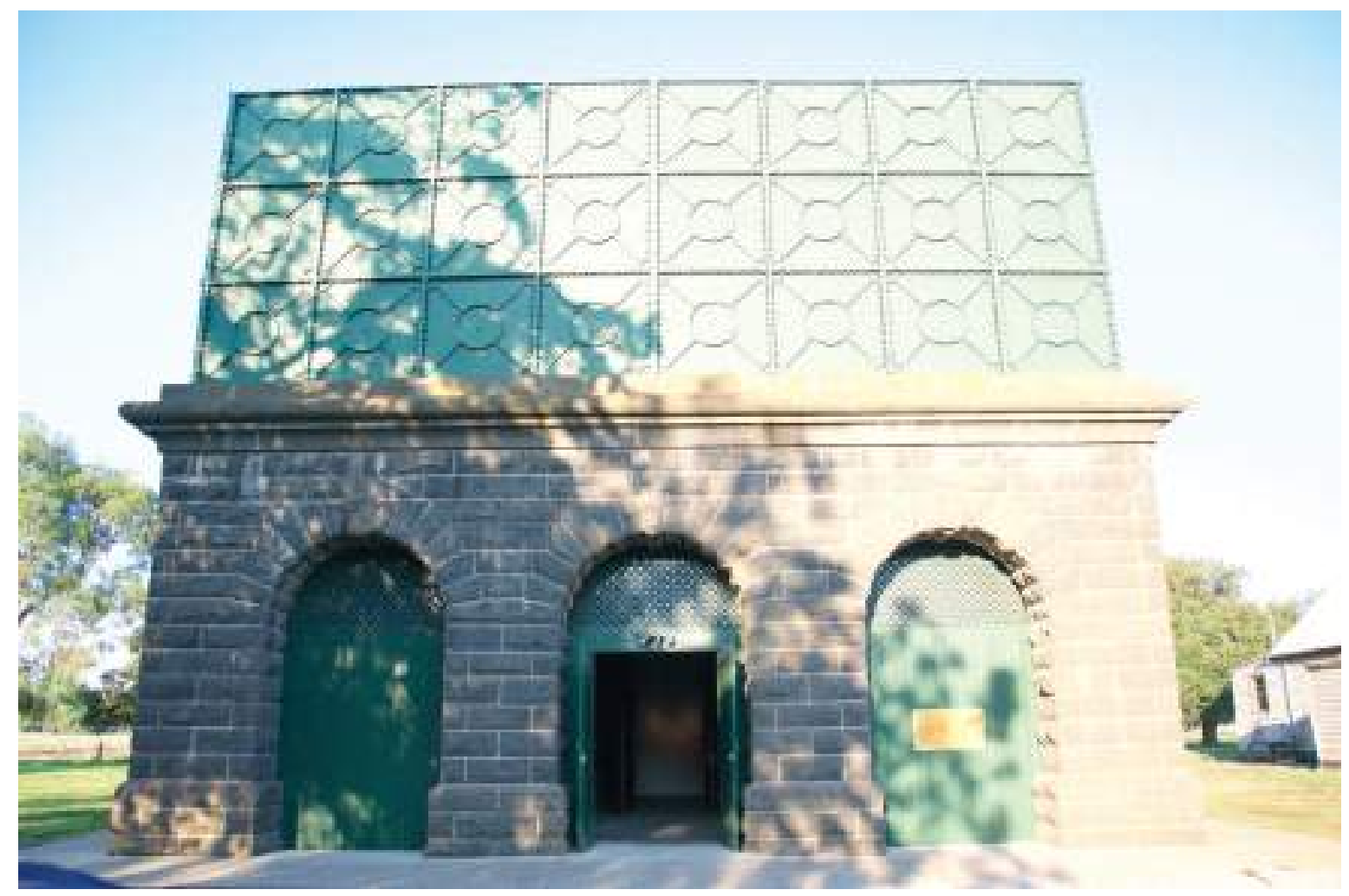

I63 | The Journal of Public Space, 3 (2), 2018 | ISSN 2206-9658 City Space Architecture / UN-Habitat 
A call out via social media invited respondents to submit a song that reminded them of the future, or that they would take into the future. Eighty nine songs later, with one original composition from one of the staff of the WTP, I extended an invitation to four electric guitarists; Billy Miller, Penny Ikinger, Sorcha Wilcox and Benjamin Cittadini to respond to the set list. Each guitarist chose four songs and through the seven hour performances they became abstracted, they became something else - a collaborative statement about the present, the time spent in the water tower, the resonance of the past and present reaching out across the landscape enveloping all that lay in its wake.

The work claimed the space in concert with the occupants of the site for those two seven hour performances.

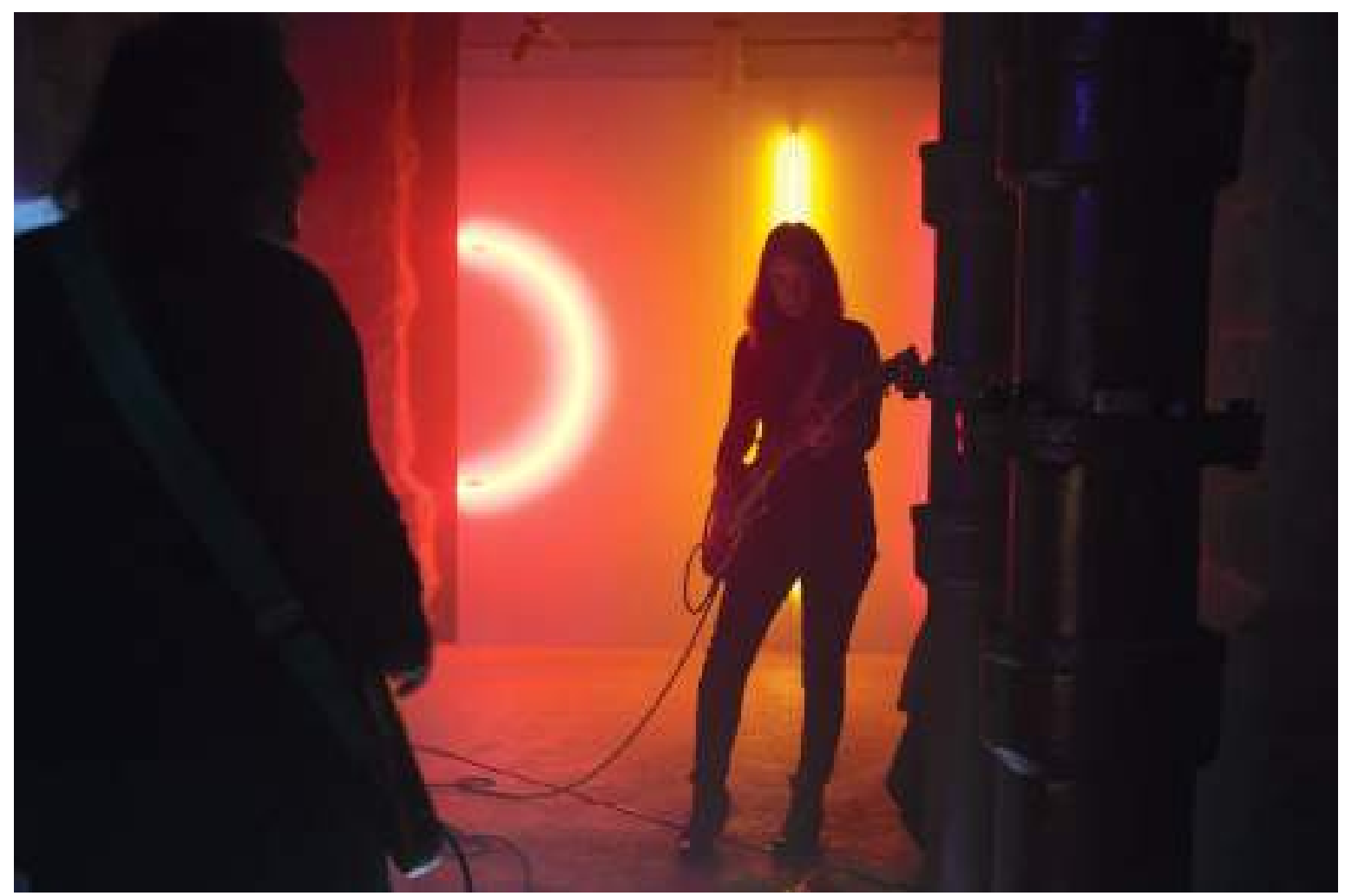



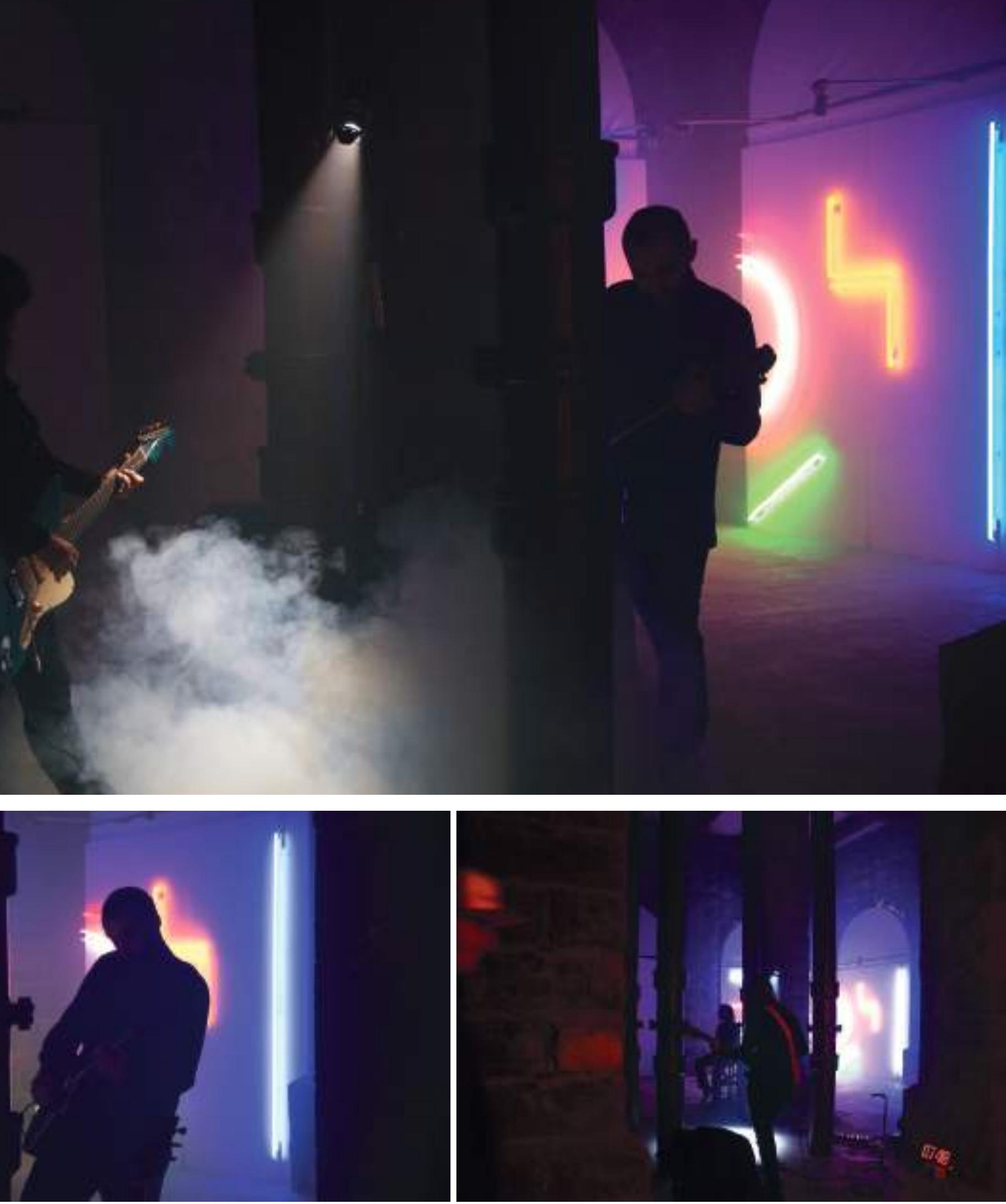

I65 | The Journal of Public Space, 3 (2), 2018 | ISSN 2206-9658 

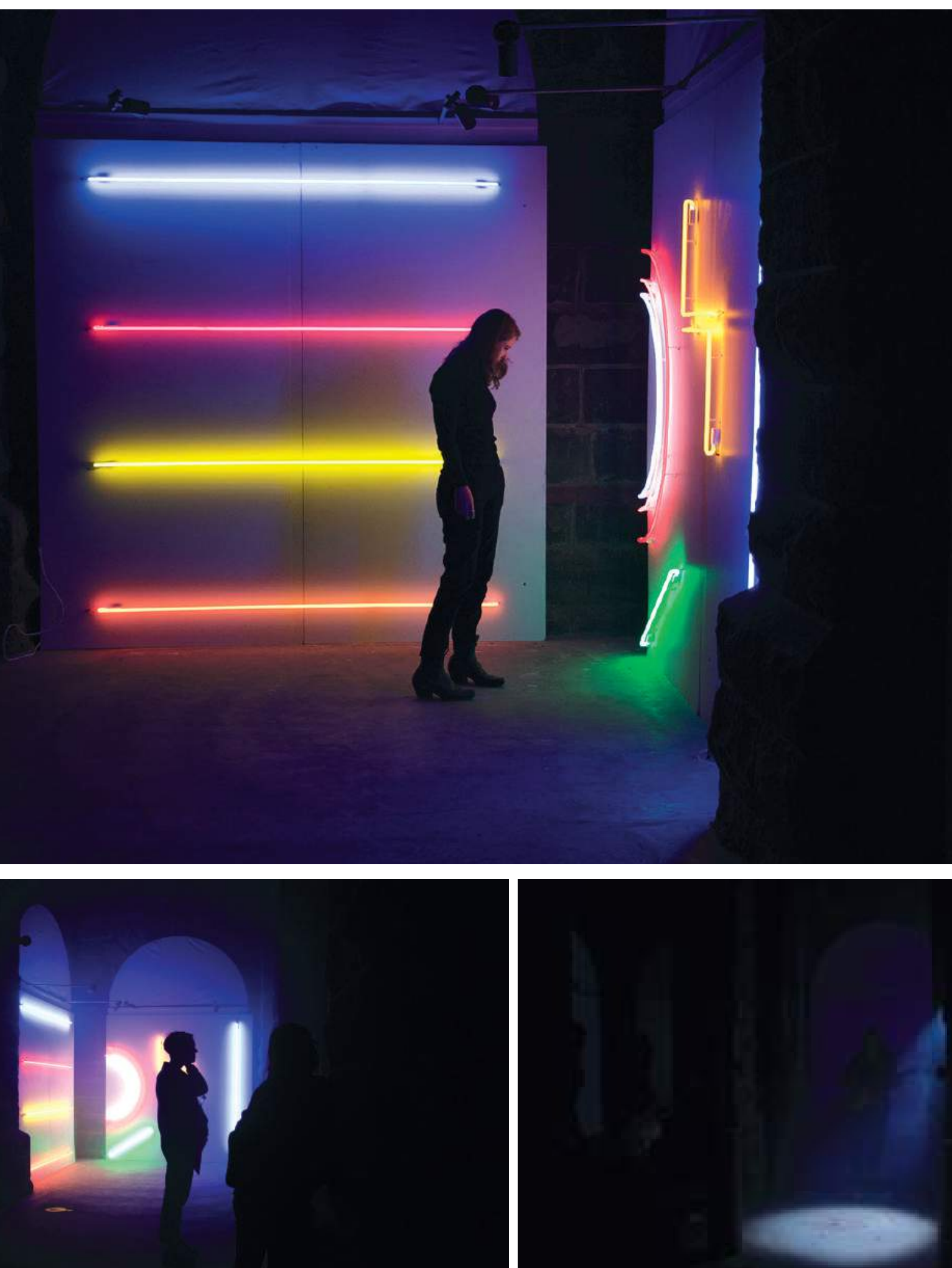

I66 | The Journal of Public Space, 3 (2), 2018 | ISSN 2206-9658

City Space Architecture / UN-Habitat 
The Journal of Public Space

ISSN 2206-9658

2018 | Vol. 3 n. 2

https://www.journalpublicspace.org

\title{
VIEWPOINT
}

\section{Canberra's first ever Parklet}

Natalia Weglarz

Planning Institute of Australia, Australian Capital Territory, Australia

ACT 2017 Young Planner of the year

natalia4004@hotmail.co.uk

\begin{abstract}
In the spring of 2016, The Australian Capital Territory (ACT) Planning Institute of Australia's Young Planners had an idea, to create Canberra's first parklet. Finally, in June 2018, the Parklet was built! It was a long and complicated journey to provide an urban renewal idea into the ACT, the result was a well utilised and loved piece of Canberra furniture. Although 4 minutes after the last barrier was removed, a car drove into the car space and it was as if the project had never happened! This article will explore the Canberra context, the feedback, how a temporary structure can change the urban fabric of the city and how Canberrans can learn from this experience.
\end{abstract}

Keywords: Canberra, parklet, pocket park, public intervention, Planning Institute Of Australia, Young Planners

To cite this article:

Weglarz, N. (20I8). Canberra's first ever Parklet. The Journal of Public Space, 3(2), I67-I72, DOI 10.3289I/jps.v3i2.1 II 4

This article has been accepted for publication in The Journal of Public Space. Please see the Editorial Policies under the 'About' section of the journal website for further information.

This work is licensed under a Creative Commons Attribution - Non Commercial 4.0 International License https://creativecommons.org/licenses/by-nc/4.0/ 
A parklet:

'A pavement/sidewalk extension repurposing I-2 car spaces back into public space. A parklet includes seating, planting and lighting and provides a space for people to enjoy their city'

\section{Introduction}

The ACT Young Planners of the Planning Institute of Australia took it upon themselves to create Canberra's first ever parklet. It has been a two year process with several setbacks but for four weeks in June 2018, the ACT was home to its first ever parklet. It was an interesting journey, as well as a great insight into the governmental processes at work; with the young planners navigating separate government departments and negotiating political willpower to achieve what the ACT Young Planners thought would be a simple goal. The Parklet took over one car parking space, with a hand built wooden structure providing seating in an $L$ shape, surrounded by concrete barriers. Planting was incorporated into the back of the Parklet to allow for a visual softening of the barriers and small LED lighting provided some ambiance.

\section{The Canberra Context and Location}

Canberra is located within the Australian Capital Territory in Australia; three hours' drive inland from Sydney and seven hours' drive north of Melbourne. In a Capital city with only 350,000 people, a variable weather system with sweltering summers and freezing winters and a sprawling city with a number of suburbs, Canberrans have taken to be heavily car dependent. A city that boasts of only having a twenty minute car commute in every direction perpetuates this thought.

Canberra's first parklet was chosen to be located on Lonsdale Street in Braddon. Braddon is known as the 'hipster' centre of the City and located a stone throw from the geographical core of the city, it has an eclectic mix of cafes, bars and restaurants adding to its enticing charm. There are several residential dwellings throughout the local area, as well being close to employment centres. All of this means there is high foot traffic throughout this area, and it provided a great spot for the Parklet to be situated. Lonsdale Street has a $50 \mathrm{~km}$ p/h (30 miles $\mathrm{p} / \mathrm{h})$ speed limit, with two lanes of traffic and three rows of on street parking bays on either pavement edge, and through the centre of the two lanes. This location is heavily dominated by cars and pedestrians weave through cars to cross the road, as formal road crossings are quite far and few between. Lonsdale Street has no public seating available down either sides of the pavement. The only seating available is linked to commercial entities. Consequently, it creates an atmosphere of commercialising public space, without any ability to use the space unless there is an exchange of money. This was one of the initiators for the parklet, showcasing a lack of public infrastructure and how that can highlight how people use space. One of the main comments received about the parklet was that people never realised Lonsdale street had no benches, they had grown so accustomed to knowing they had to use a commercial tenancy to access seating they never questioned that that could be changed. All these factors encouraged the ACT Young Planners to make Lonsdale Street the natural choice for a public intervention to give the space back to the people. Lonsdale street makes sense to be more pedestrian friendly, it is the main area for dinner and 
nights out within Canberra, and the lack of public infrastructure makes it exclusionary for certain sections of society. The key to public space is to allow a mix of people to interact both directly and indirectly, and the Young Planners found the parklet was a great way to start this process. We took inspiration from Times Square in New York and the impending close of Oxford Street in London on how to reclaim car dominated spaces back for pedestrians.

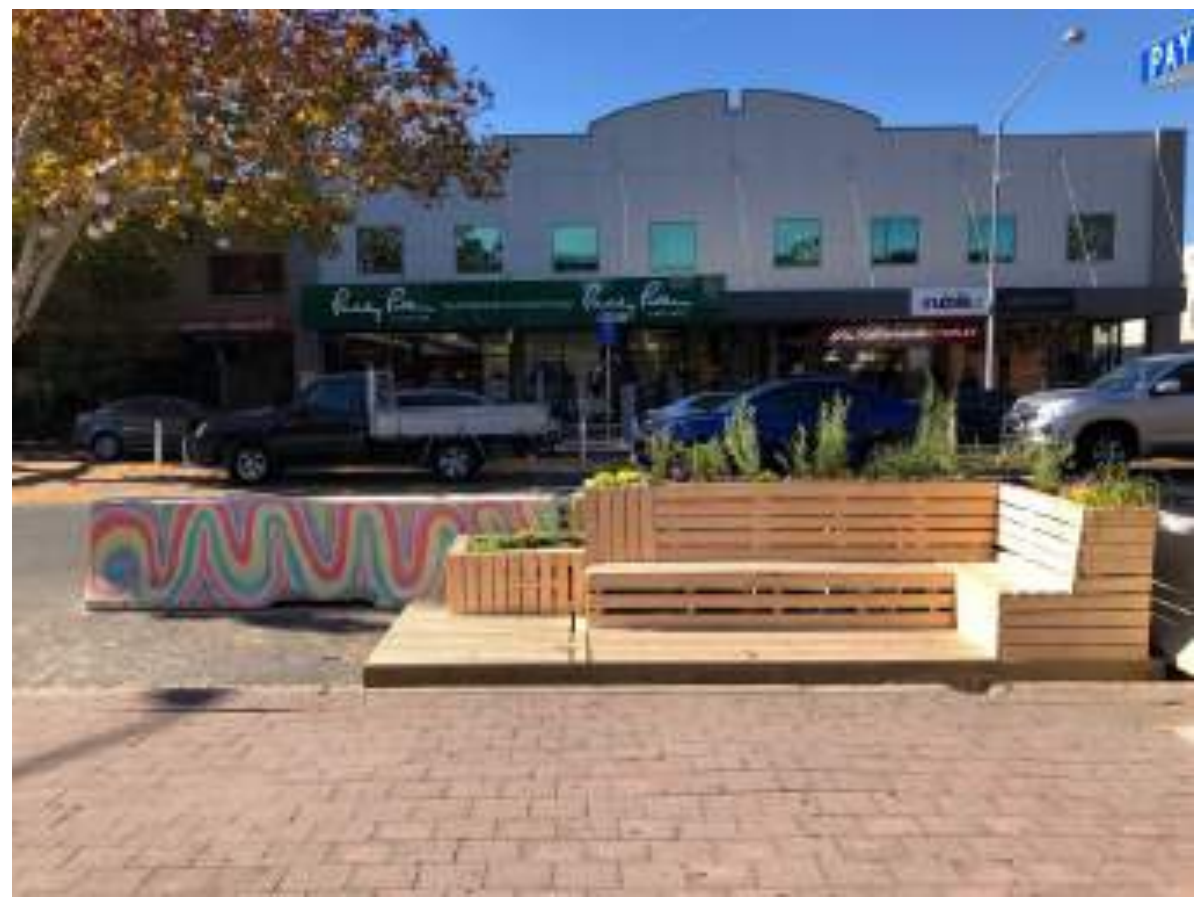

Figure I. Parklet in Lonsdale Street, Canberra, Australia.

\section{Government Response}

The ACT Young Planners found the ACT government to be divided about the idea of a parklet. The City Renewal Authority (CRA) who provided the funding are focused on providing urban intervention initiatives within the city and therefore were heavily supportive of the initiative. Politically, the project was well received, with the project team receiving support letters from several ministers within the local assembly. Although Transport Canberra City Services (TCCS) who provide Canberra's municipal services and engineering services were weary of the project and provided a number of Australian Standard adherences to the project.

A Parklet is not a new idea, it's been around for about ten years now from San Francisco to Sydney, as well as in Melbourne and Adelaide. Other Australian jurisdictions were able to work within the legislative framework and find a workable, suitable solution to the idea of a parklet. The ACT Young Planners found TCCS were incredibly weary of providing support for a project such as a parklet on a $50 \mathrm{~km} / \mathrm{ph}$ road, next to traffic, and found it difficult to fit the project into their current framework. Even with Australian examples of cities that had worked through the same issues TCCS were discussing. It was a battle to bring them to the table and allow the Young Planners to execute a public space intervention that will improve the locality. After 8 months of discussions TCCS were willing to accept three concrete crash barriers surrounding the parklet. For anyone who's 
ever been in contact with concrete barriers, they are very big, not very movable and quite expensive to hire and manoeuvre. The cost of installing the barriers was roughly $60 \%$ of the entire parklet budget. This highlighted the disconnect between the two different government departments. One promoting international examples of excellence and public interventions, and one department providing parameters which, while ultimately workable, stunted the overall possibilities of the project.

\section{Local Business Response}

Speaking to the local bar, restaurant and shop owners before the parklet people seemed supportive of the initiative. The main hesitation was over the loss of the one parking space. In discussions it was discovered that the local workers held spaces for each other on Lonsdale Street, and it wasn't usually the public who utilised the spaces. Therefore, it wasn't necessarily a loss of general, public parking, but spaces for the workers of the local establishments this parklet was altering. This initiative removed one parking space from use for 4 weeks.

While a temporary inconvenience, the overall benefit for the locality was highlighted in the overwhelming positive vibe the planners received while building and using the parklet over the month. Other business owners stopped the planners who were making the parklet to ask if they could get a parklet built outside their business, or how could they get involved with the parklet.

Ultimately the proof was in the pudding, having the parklet built and functional allowed people to understand how the space was being used and what the benefits were for the locals and the businesses. People were able to see how the parklet encouraged people to dwell, and to experience their public space differently than they had thought they could.

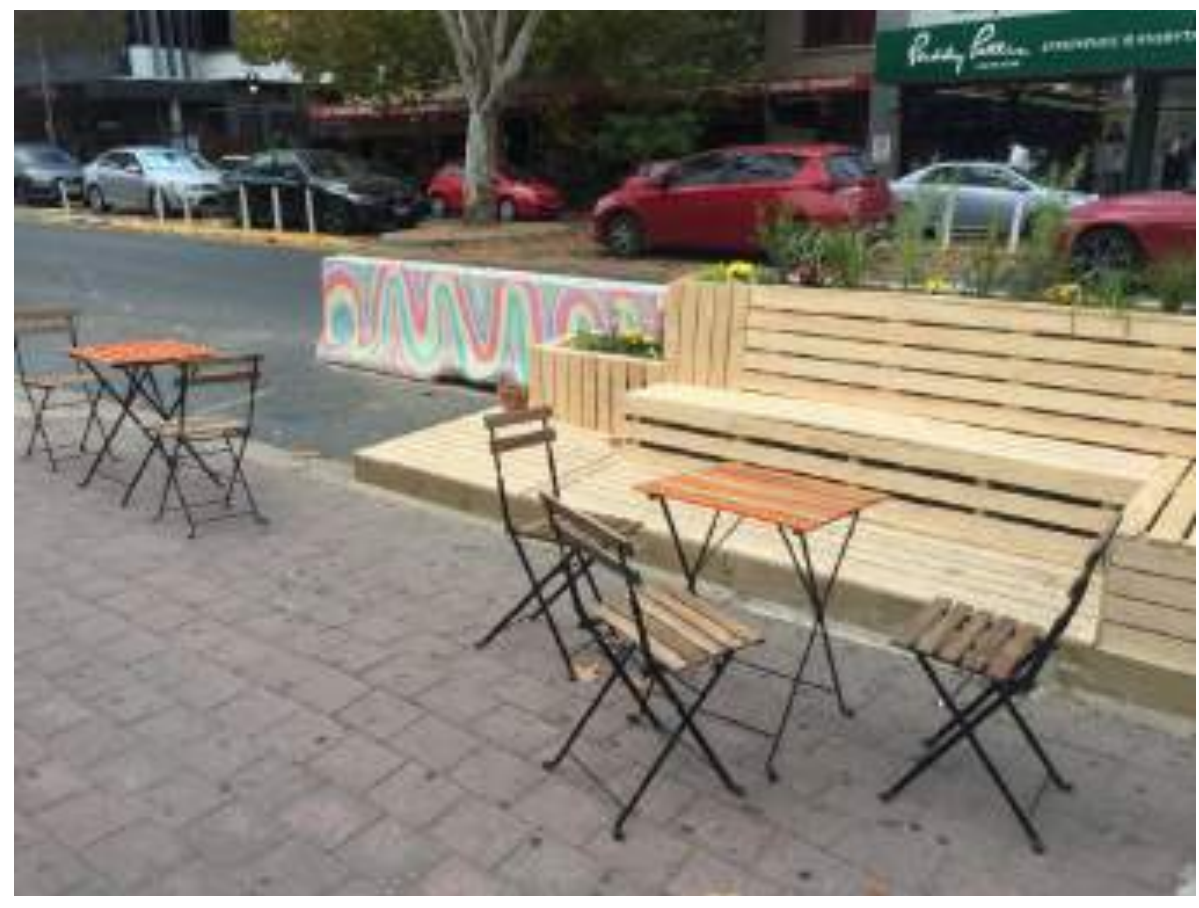

Figure 2. Parklet in Lonsdale Street, Canberra, Australia. 


\section{Parklet Use}

The parklet was used as it had been intended, a lunch spot, a coffee point and a meeting place. Workers nearby would use the parklet to eat their lunch in the sun, within Lonsdale Street there are no close places to eat in the sun while still being close to the offices. The parklet filled a much-needed gap in the amenity for locals. And on one instance had been used as a stop for Canberran to check their blood sugar level in a quiet space without having to resort to entering one of the establishments. It's the unexpected use of space that the Young Planners applauded, the parklet really become a part of the fabric of Braddon, people used it as they felt fit. Children climbed on the seating and played with the plants and parents could take a quick break without having to sit in a specific café.

The bar where the parklet was situated in-front of had some fantastic insights into the parklet use after dark. Unexpectedly it had also become an evening collection point of smokers from the nearby bars. One of the main improvements the business owners found was with smokers having a stable, permanent place to congregate while on a night out. Before the parklet, the local bouncers would see people disperse through cars, ultimately endangering themselves and potentially causing accidents. When the parklet was in situ, the smokers stayed within the space, caused less safety issues, decreased overall litter as they used the cigarette butt bins provided, and were safer than before. These predicted and organic uses were a great testament to the usability of the parklet, and the suitability of the chosen location. The organic footfall of people walking from the city centre into Braddon and the change in user demographics between the morning coffee crowd, the lunch crowd and the evening entertainment crowd meant an almost round the clock parklet utilisation. There were two separate tables and four chairs left out with the parklet, and for the whole parklet timeframe, none of these extra parts of the parklet were stolen or damaged. A great testament to the design and use of the parklet.

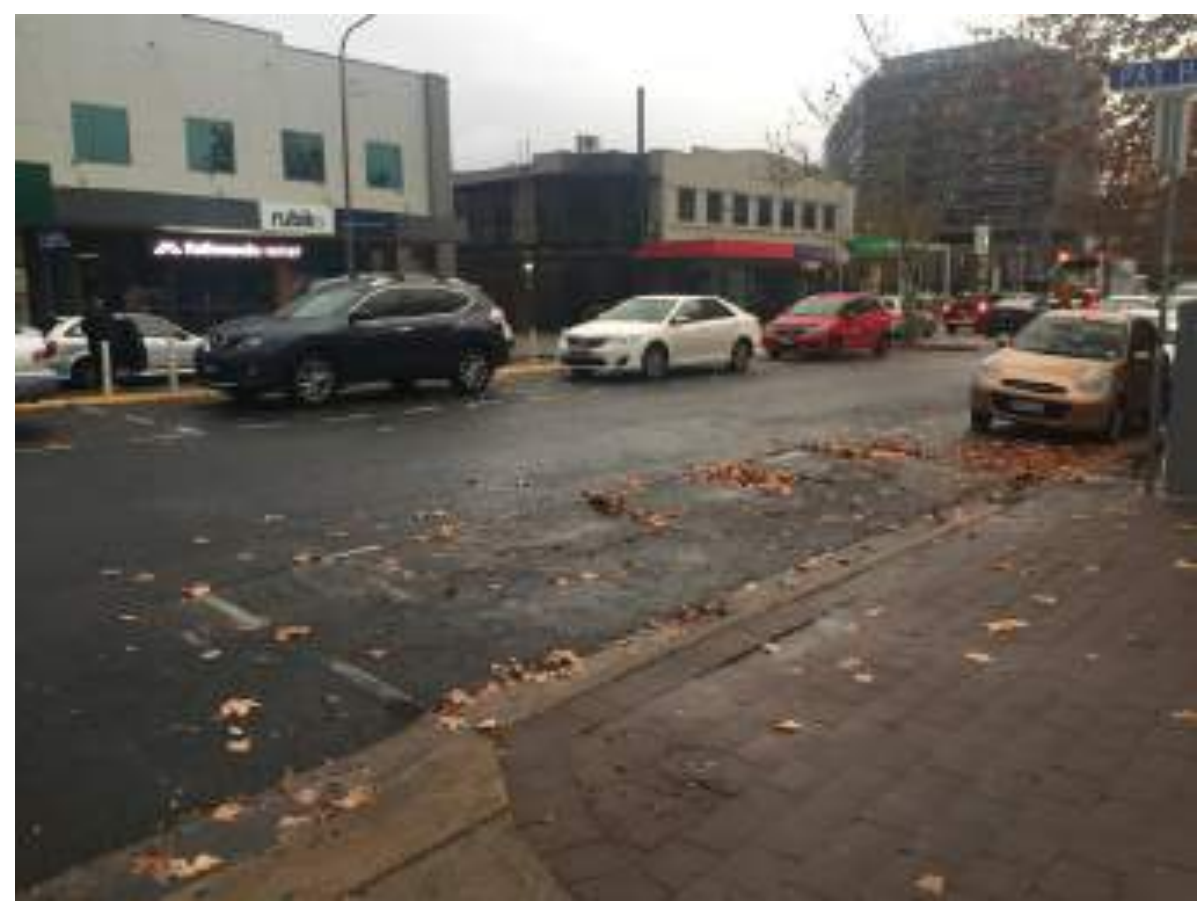

Figure 3. Lonsdale Street, Canberra, Australia, after the parklet. 


\section{Future}

Canberra will not suddenly stop being car dependent, but with this public intervention, the Young Planners have started a conversation about utilising space differently. Encouraging people to see space not in its designated use, but as a place where change could happen.

Canberrans are proud of their capital, but there is a large contingent of people who are afraid of change or effecting the status quo. Introducing news ideas will always have opponents, but it is key to drill into the reason of the opposition. Canberrans like the ability to park outside the establishment they're visiting, and removing a parking space, even if the public rarely were able to use it, challenged this notion. There will always be people who will never agree with the utilisation of public space in this manner, although providing opportunities for people to use and think about public space differently will enable more people to be open to change in the future.

The ACT Young Planners are hoping to create a simple step by step guide to undertaking a parklet in Canberra. They want to make sure that these types of interventions are replicable and any groups who would like a parklet within their locality are able to do so. The Young Planners have a design, a proven budget, and most importantly have already navigated the governmental processes and this should pave the way for future parklets. Making our communities better by small, innovative interventions is what makes our cities different and interesting. While the process may have been long and challenging at times, there was a great sense of achievement when the parklet was built. This achievement has spurred the Planning Institute of Australia ACT Young Planners into thinking of the next public space intervention they could undertake. Although with the last two years having taken a mammoth effort, a break is probably in order to allow for the passion to grow again.

\section{Acknowledgment}

This project would not have happened without John Reschke and Jacob White from the ACT PIA Young Planners. I would like to thank their tireless efforts in staying motivated over the last 2 years. I would also like to extend that thanks to the whole 2016-2018 ACT Young Planner Committee who have helped throughout the two-year period in various capacities. The City Renewal Authority provided the funding and governmental communication to the project. The "pop-up" temporary parklet was also helped by Penny Hardy of Design Community, Kieran IgoeTaylor of Projex Building, and Knight Frank Town Planning Canberra. 
The Journal of Public Space

ISSN 2206-9658

2018 | Vol. 3 n. 2

https://www.journalpublicspace.org

\title{
VIEWPOINT
}

\section{The urban lounge and a green view.}

A temporary art installation in Bologna during the

\section{Art City White Night}

\section{Luisa Bravo}

City Space Architecture, Italy

luisa.bravo@cityspacearchitecture.org

\begin{abstract}
'The urban lounge and a green view' was a temporary art installation promoted by City Space Architecture in collaboration with bAQ, Bottega Azioni Quotidiane, a young group of Architecture students from the University of Florence. It was part of the 'Arte Fiera. International Fair of Modern and Contemporary Art' in Bologna, Italy, and took place during the 'Art City White Night' on January 25, 20I4. It was intended to transform two parking spots in the core of the historic city of Bologna into places of social interaction. It was inspired by the worldwide famous Park(ing) Day, started in 2005 by Rebar in San Francisco.
\end{abstract}

Keywords: Bologna, Art City White Night, parking space, City Space Architecture, bAQ

To cite this article:

Bravo, L. (2018). The urban lounge and a green view. A temporary art installation in Bologna during the Art City White Night. The Journal of Public Space, 3(2), 173-I78, DOI 10.3289I/jps.v3i2.1III5

This article has been accepted for publication in The Journal of Public Space. Please see the Editorial Policies under the 'About' section of the journal website for further information.

This work is licensed under a Creative Commons Attribution - Non Commercial 4.0 
The initial PARK(ing) intervention occurred on November 16, 2005 from noon until 2 p.m., without incident or interference from any level of institutional authority. Sort of makes you wonder what else you can do in a parking space ...

Rebar, San Francisco, 2005

\section{Who said that parking spaces are just for cars?}

When you need to park your car in the city centre of Bologna, if you are not a resident you most probably have to pay in order to rent the parking space for a given time. You pay money, so the space is yours for as long as you need to park your car. So why not using it for other activities instead of parking?

This is what I thought when with my organization City Space Architecture, in collaboration with bAQ, Bottega Azioni Quotidiane, I applied for an art installation to be included in the 'Art City White Night' in 2014, as part of 'Arte Fiera. International Fair of Modern and Contemporary Art' in Bologna, Italy's longest running art fair and the leading national event in terms of sales'. We were inspired by the work of the design studio Rebar in San Francisco in 2005, which transformed a single metered parking space into a temporary mini public park in the SOMA district, that was known to be underserved by public open space. Just by rolling out living grass, putting up a bench and placing a potted tree, they created an opportunity for social interaction: as Rebar described 'within minutes, a man sat down on the bench, took off his shoes, and began to eat lunch, another person joined soon after, and the two began having a conversation'.

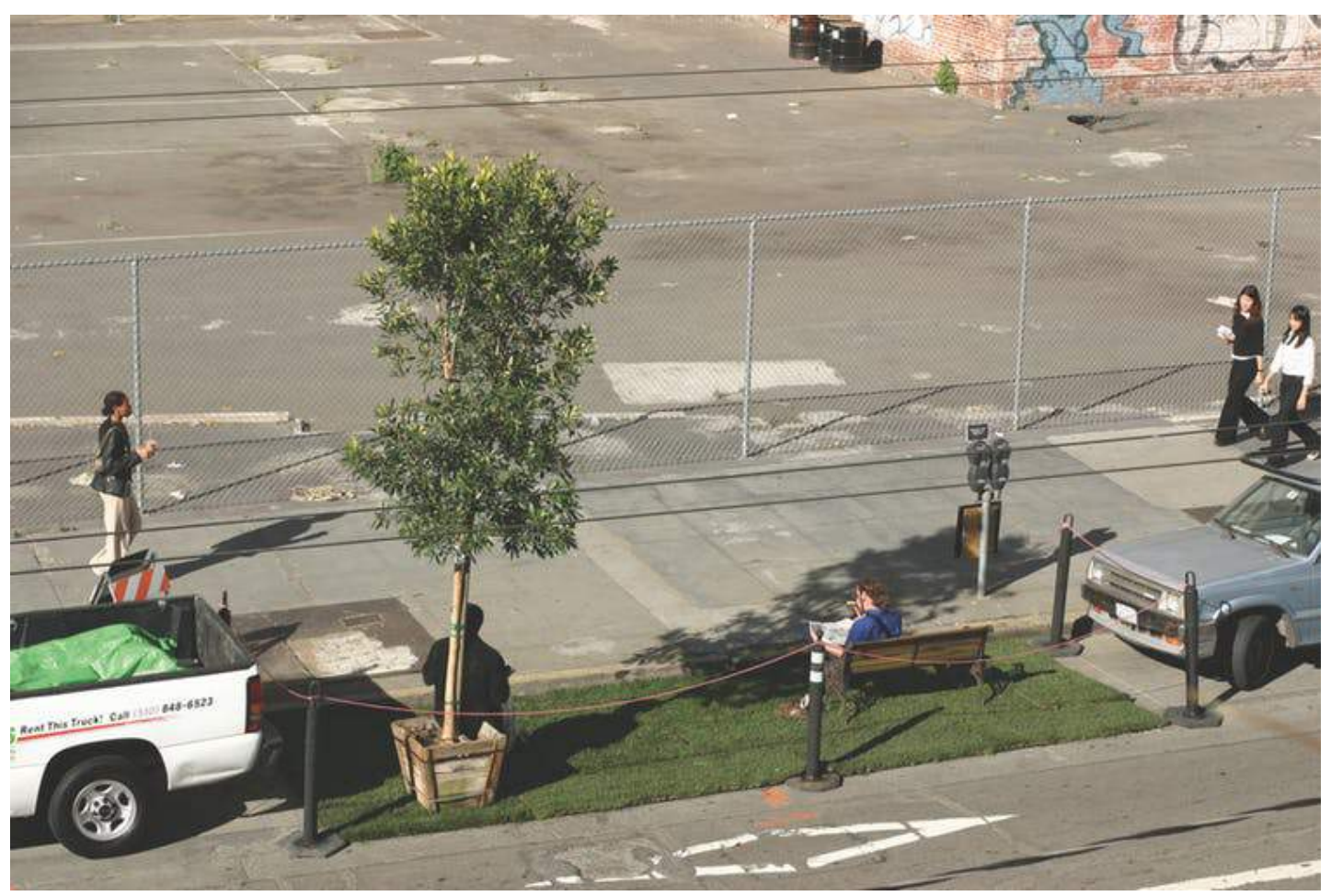

Figure I. The original Park(ing) installation on Ist and Mission Streets in San Francisco (Rebar Group).

\footnotetext{
I Arte Fiera: http://www.artefiera.it/en/home/776.html. Accessed August 15, 2018.
} 
At that time, $70 \%$ of San Francisco's downtown outdoor space was dedicated to the private vehicle, while only a fraction of that space was allocated to the public realm. But after the Rebar's Park(ing) installation, the idea to reuse the parking space for public use soon became the expression of an alternative thinking, reclaiming public space as a fundamental value for urban life. After that, Rebar prepared an how-to manual, addressing the technical aspects of Park(ing) installations, intended to share what they called 'an act of generosity' with anyone was interested to create his/her own park. Later Rebar received support from the Trust for Public Land and the Park(ing) Day went global: in 2006 it was celebrated with 47 'parks' in 13 cities across three countries and then expanded to more than 200 parks in 2007 and featuring in the Venice Architecture Biennale in 2008. By 20 I I PARK(ing) Day included almost I,000 parks in 35 countries. In 2008 the City of San Francisco approached Rebar to prototype 'parklets', as more permanent Park(ing) style installations, sponsored by local businesses, and later to start the Pavement to Parks program (https://groundplaysf.org/parklets/).

The Park(ing) Day was a huge success and inspired new ways to improve public space, from 'lighter, quicker, cheaper interventions', as defined by place-making experts working at Project for Public Spaces in New York City, to tactical urbanism, intended as shortterm actions for long-term change ${ }^{2}$.

\section{Re-imagining the use of the urban parking space} In the 60's Piazza Maggiore in Bologna was full of cars.

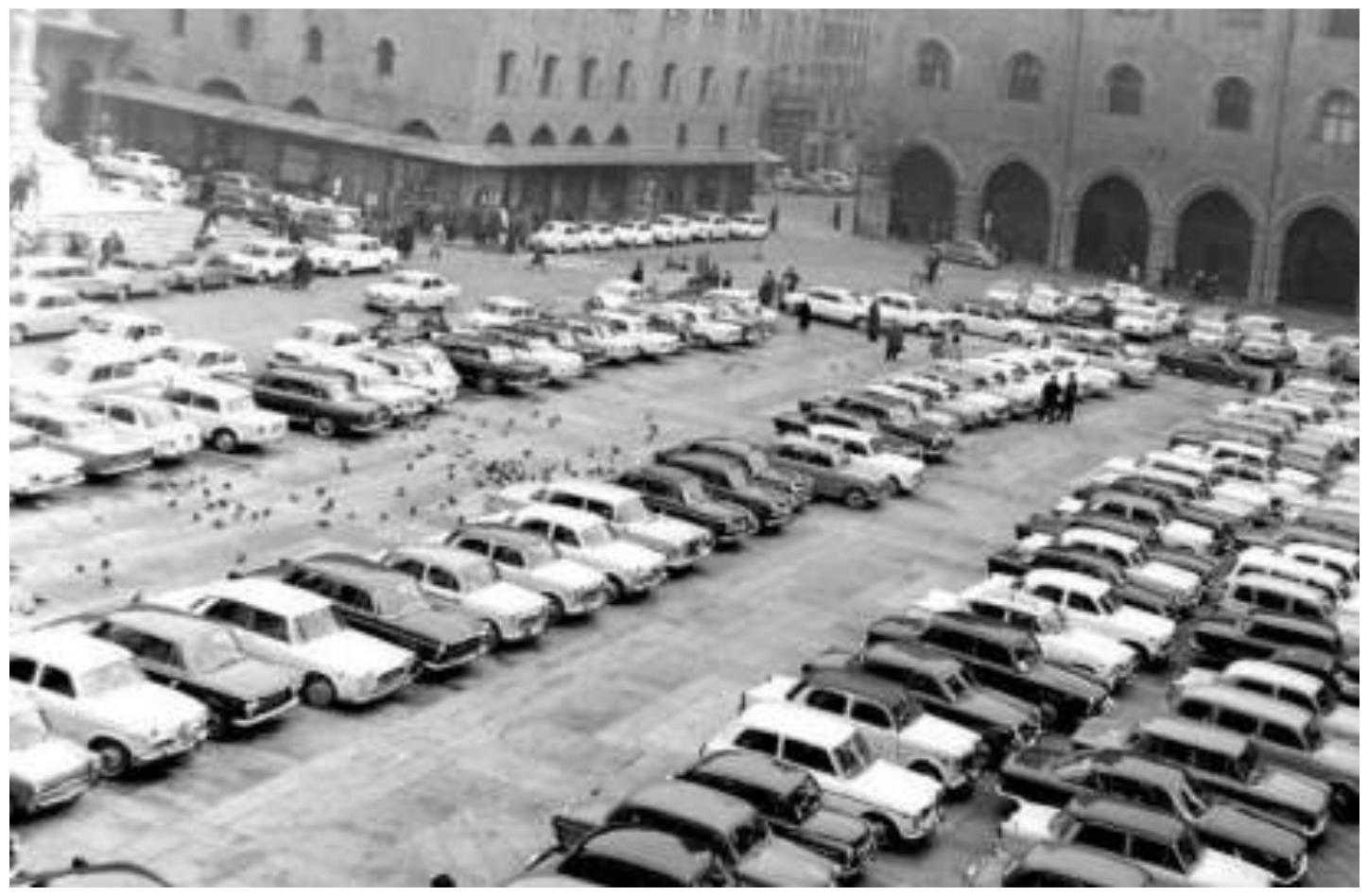

Figure. 2. Bologna, Piazza Maggiore, 1960’s.

\footnotetext{
${ }^{2}$ Lydon, M. (2012), Tactical Urbanism. Short-term action, long-term change, The Street Plans Collaborative, Miami-New York, available on line: http://tacticalurbanismguide.com/guides/
} 
In 1968 the Muncipality implemented a pedestrian use of the piazza, so all cars were removed. But the city centre remained congested by car traffic and still today it is almost impossible to find a parking spot during the rush hours. As a consequence, the pedestrianization of a defined part of the city centre is still one of the crucial and largely discussed urban issues. A recent programme 'Di nuovo in centro', promoted by the Municipality and adopted in 20 I I, was intended to define a pedestrian-friendly use of the urban space in the city centre, by improving accessibility, by bus and by bicycle, and by redeveloping the public space and regulating its use ${ }^{3}$, by allocating new parking areas and by reorganizing the traffic flows entering the city centre.

The art installation 'The urban lounge and a green view' took place along one of the main streets in the urban core of the city of Bologna, Via Santo Stefano, a street leading to Piazza Santo Stefano, one of the most beautiful piazzas in the historic centre of Bologna, close to the Leaning Towers.
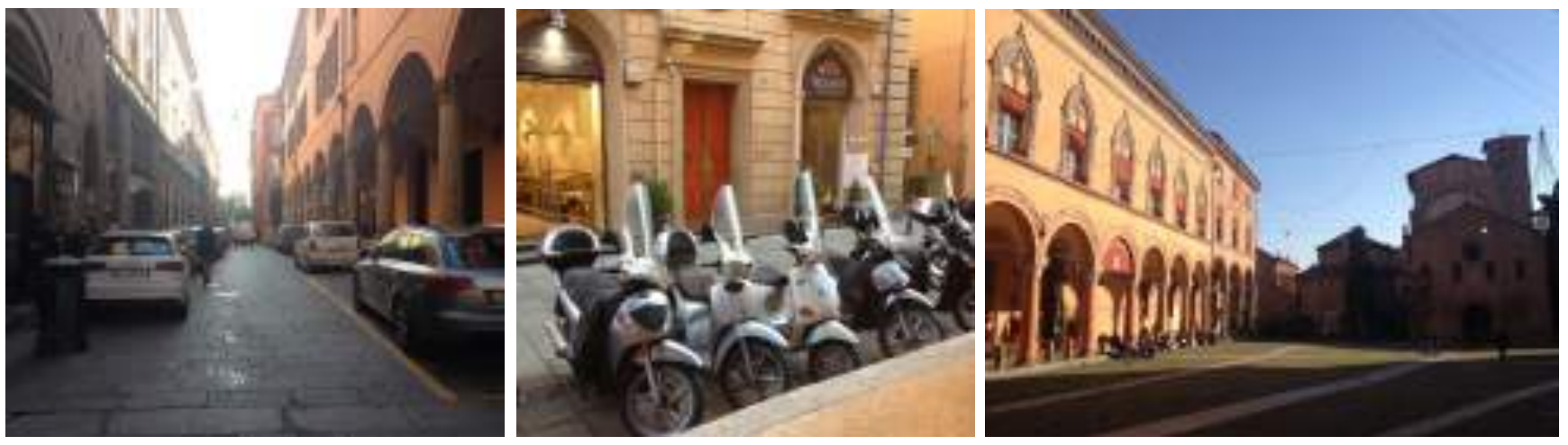

Figure. 3, 4. Via Santo Stefano and Piazza Santo Stefano.

The installation was placed within the footprint of two parking spots, so 2.5 by 10 meters wide. We applied for formal authorization to the Muncipality for the use of the space and we asked residents to be patience and leave the two parking spaces empty for our installation. Surprisingly, nobody complained.

The parking spots were transformed, from 6:00 pm to midnight, into a urban living room and its garden, so we put outdoor a domestic environment. Staging the intimacy of daily indoor activities, our question was: if you care about your home why don't you care enough about the public space, which is your home in the city? With this provocation, we intended to open a discussion about the potential of the urban spaces of the city core: how many urban living rooms for social interaction could replace parking spots? And how many urban living rooms do we need to make a livable city?

We printed a pamphlet called 'La Res Publica', which means 'The public good' - evoking the Italian newspaper 'La Repubblica' - that we distributed to all those who came and sat on our sofa or in the garden.

\footnotetext{
3 Municipality of Bologna, Di nuovo in centro (20l4), http://www.comune.bologna.it/media/files/di_nuovo_in_centroucb_deff.pdf. Accessed August 15, 2018.
} 

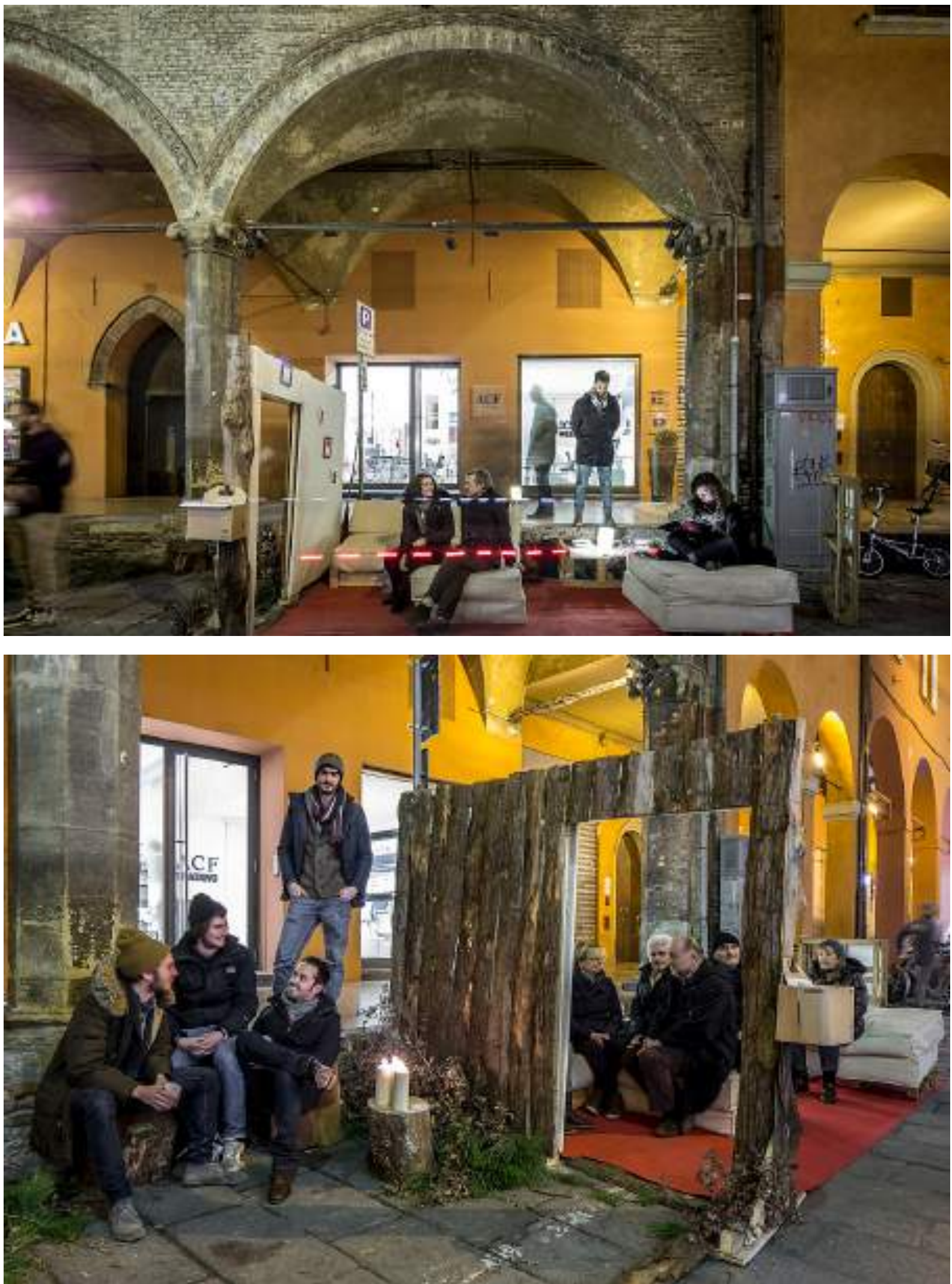

Figure. 5, 6 and 8 (next page). The urban lounge and a green view, Art City White Night, Bologna, 2014. Photos by Fabio Mantovani. 


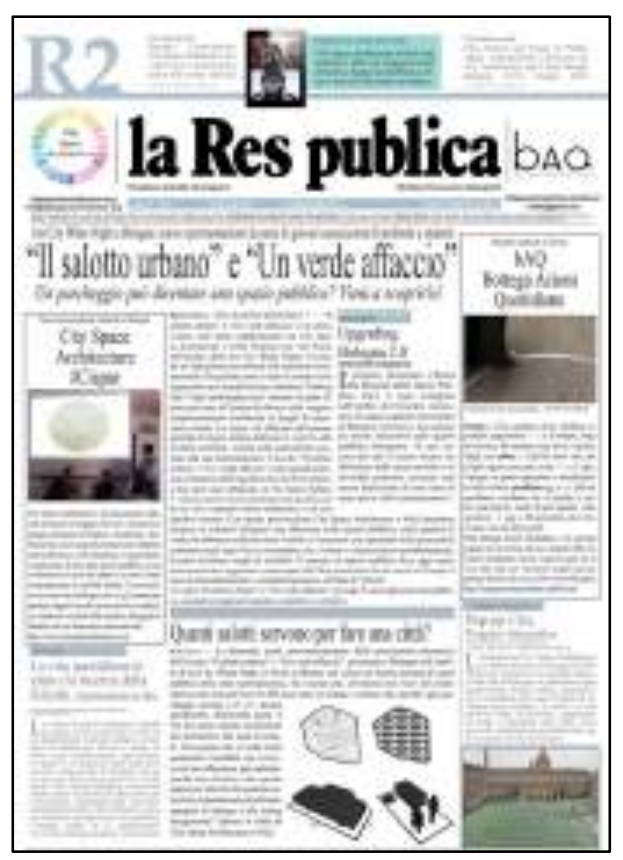

Figure. 7. Our pamphlet 'La Res Publica'.

How many urban living rooms do we need to make a livable city?

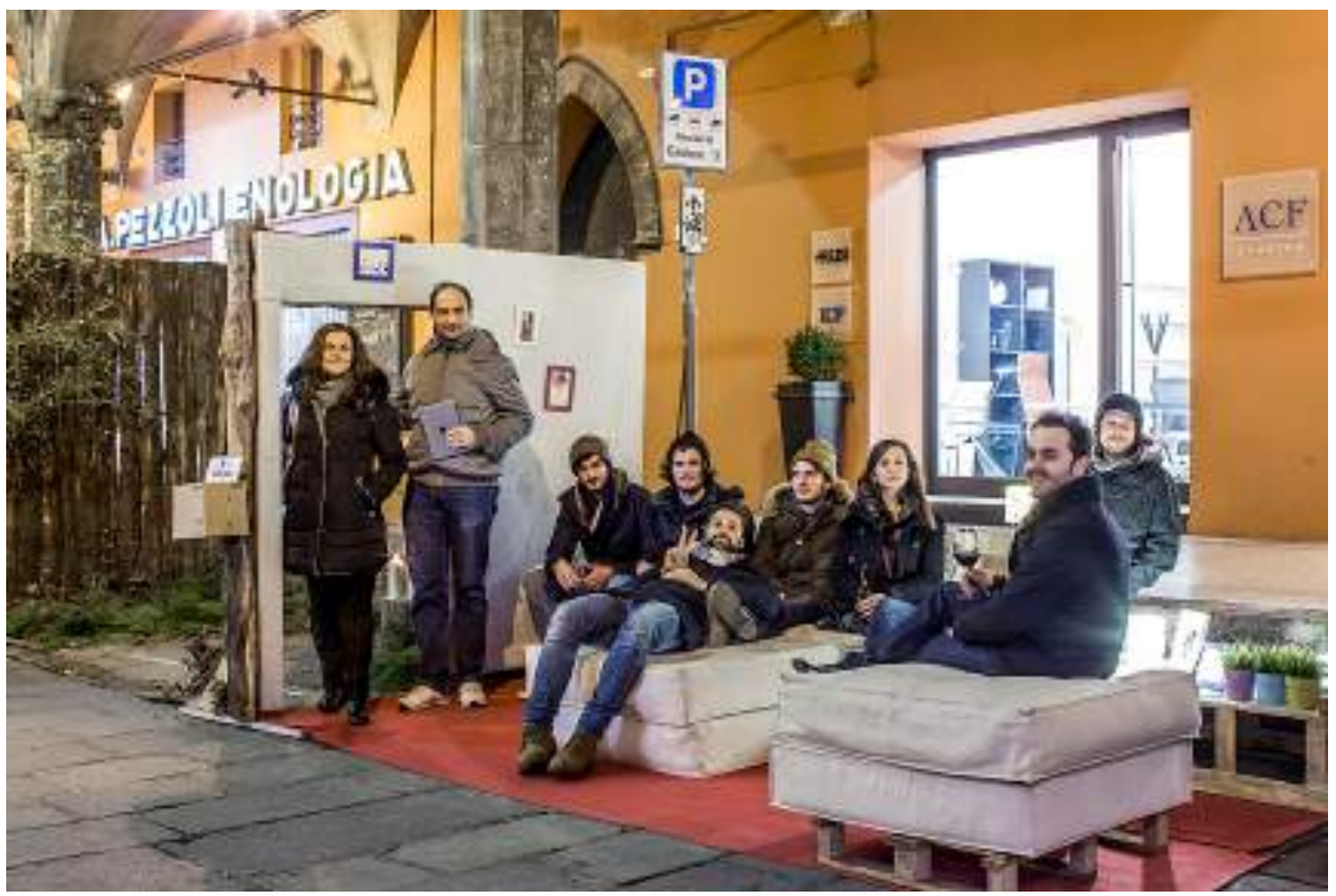

\section{Acknowledgment}

A special thanks to the team of City Space Architecture, Simone Garagnani, Valerio Francia, Camilla Carmagnini and Francesco Ciampolini, and to bAQ, Antonio Salvi, Francesco Polci, Filippo Pecorai, Giovanni Manzoni, Alessio Piomboni, Francesco Onorati, Giacomo Razzolini, Giacomo Fondelli. Thanks also to Spazio \& Forme for the interiors of our lounge and to Tresanti wine bar for the good wine and the friendly hospitality. 
Thank you for reading!

The Journal of Public Space

ISSN 2206-9658

Editor in Chief Luisa Bravo

City Space Architecture Italy

https://www.journalpublicspace.org 